\title{
Het gezamenlijk consult van huisarts en specialist in de eerste lijn : een nieuwe werkwijze bij klachten van het bewegingsapparaat
}

Citation for published version (APA):

Vierhout, W. P. M. (1994). Het gezamenlijk consult van huisarts en specialist in de eerste lijn : een nieuwe werkwijze bij klachten van het bewegingsapparaat. [Doctoral Thesis, Maastricht University].

Rijksuniversiteit Limburg. https://doi.org/10.26481/dis.19940428wv

Document status and date:

Published: 01/01/1994

DOI:

10.26481/dis.19940428wv

Document Version:

Publisher's PDF, also known as Version of record

\section{Please check the document version of this publication:}

- A submitted manuscript is the version of the article upon submission and before peer-review. There can be important differences between the submitted version and the official published version of record.

People interested in the research are advised to contact the author for the final version of the publication, or visit the DOI to the publisher's website.

- The final author version and the galley proof are versions of the publication after peer review.

- The final published version features the final layout of the paper including the volume, issue and page numbers.

Link to publication

\footnotetext{
General rights rights.

- You may freely distribute the URL identifying the publication in the public portal. please follow below link for the End User Agreement:

www.umlib.nl/taverne-license

Take down policy

If you believe that this document breaches copyright please contact us at:

repository@maastrichtuniversity.nl

providing details and we will investigate your claim.
}

Copyright and moral rights for the publications made accessible in the public portal are retained by the authors and/or other copyright owners and it is a condition of accessing publications that users recognise and abide by the legal requirements associated with these

- Users may download and print one copy of any publication from the public portal for the purpose of private study or research.

- You may not further distribute the material or use it for any profit-making activity or commercial gain

If the publication is distributed under the terms of Article $25 \mathrm{fa}$ of the Dutch Copyright Act, indicated by the "Taverne" license above, 
HET GEZAMENLIJK CONSULT VAN HUISARTS EN SPECLALIST IN DE EERSTE LIJN 


\section{Het gezamenlijk consult \\ van huisarts en specialist \\ in de eerste lijn}

Een nieuwe werkwijze bij klachten van het bewegingsapparaat

ter verkrijging van de graad van doctor

aan de Rijksuniversiteit Limburg te Maastricht, op gezag van de Rector Magnificus,

Prof. dr. H. Philipsen,

volgens het besluit van het College van Dekanen,

in het openbaar te verdedigen op

donderdag 28 april 1994 om 16.00 uur

door

WIJNANDUS PIETER MARIA VIERHOUT

geboren te Koudekerke 
Promotores:

Prof. dr. J.A. Knottnerus

Prof. dr. H.F.J.M. Crebolder

Co-promotor:

Dr. A. van Ooij

Beoordelingscommissie:

Prof. dr. A. J. van der Linden, voorzitter

Prof. dr. H. Philipsen

Prof. dr. P. Pop

Prof. dr. F. Sturmans

Prof. dr. Th. B. Voorn (Universiteit Utrecht)

Het onderzoek werd verricht door de vakgroepen Huisartsgeneeskunde en Orthopaedie van de Rijksuniversiteit Limburg, in samenwerking met het Diagnostisch Coördinerend Centrum van het Academisch Ziekenhuis Maastricht (AZM) met subsidie van het Ministerie van Welzijn, Volksgezondheid en Cultuur, in het kader van het door het Ministerie aan te wijzen onderzoek ten laste van het Algemeen Fonds Bijzondere Ziektekosten beheerd door de Ziekenfondsraad (projectnummer 88-29).

De uitgave van dit proefschrift kwam mede tot stand door een bijdrage van de firma E. Merck Nederland BV te Amsterdam. 
Aan mijn moeder

Aan Pauline 
Paranimfen:

M.L.H. Coenen-Bours

A.M.K. Wesselingh-Megens 


\section{Voorwoord}

De verzuchting 'Hier zou ik ook wel willen werken', uitgesproken door een klinisch hoogleraar die nog niet kon beschikken over adequate werkruimte in het ziekenhuis St. Annadal, na afloop van een bijeenkomst ter voorbereiding van een nascholingsprogramma in ons gezondheidscentrum, zette mij destijds aan het denken.

Het idee van het gezamenlijk consult was mede vanwege onze meningen over het verwijsbeleid daarop snel geboren. Korte tijd later deden we ervaring op met de specialismen orthopaedie, dermatologie en KNO-ziekten.

Omdat de resultaten positief leken voor patiënten, huisartsen en specialisten, namen de huisartsen van de gezondheidscentra 'Heer' en 'van Kleef te Maastricht daarna deel aan een pilotstudie voor het specialisme orthopaedie.

Het gezamenlijk consult zou adequate oplossingen kunnen bieden in een gezondheidszorg die anoniemer en defensiever wordt en waar heden ten dage door een ziektekostenverzekering al reclame wordt gemaakt met de aanprijzing 'dat de 'second opinion' vaak nodig kan zijn en vanzelfsprekend zal worden betaald'.

Het gezamenlijk consult leek volgens de pilotstudie te resulteren in een toename van de behandelingsmogelijkheden van de huisarts en een aantal verwijzingen te voorkomen.

In de gezondheidszorg leggen positieve ervaringen op zich onvoldoende gewicht in de schaal om veranderingen tot stand te brengen. Informatie die inzicht geeft over de inhoud en het resultaat van een nieuwe ontwikkeling is hiervoor een voorwaarde.

Het proefschrift dat het onderzoek naar effecten en haalbaarheid van gezamenlijke consulten in de huisartspraktijk beschrijft, is om deze reden tot stand gekomen. 


\section{boownooV}

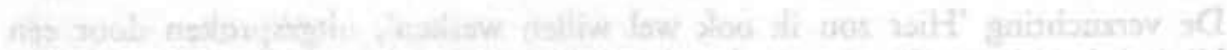

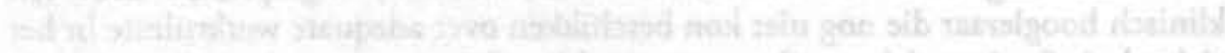

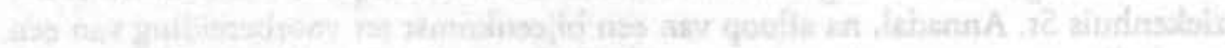

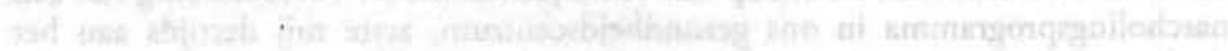
masingh

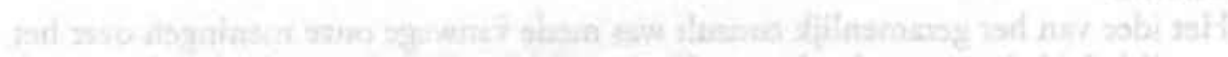

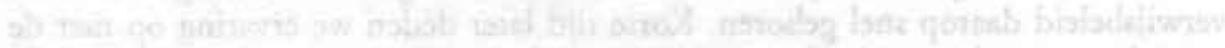

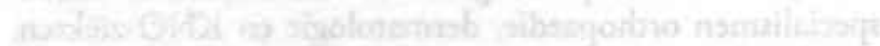

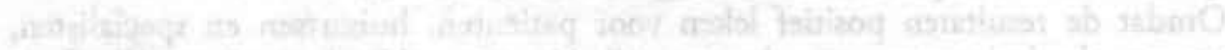

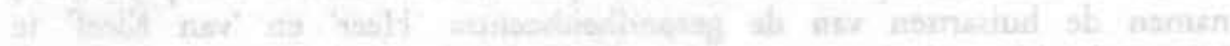

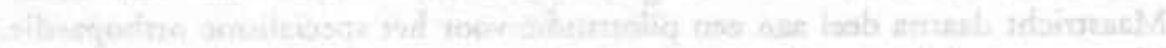

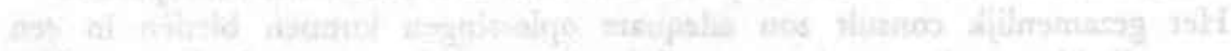

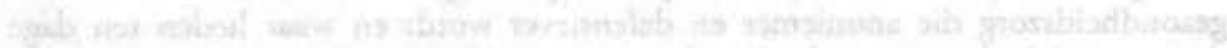

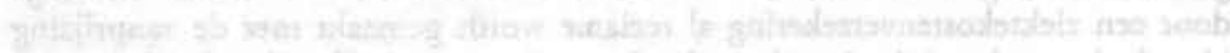

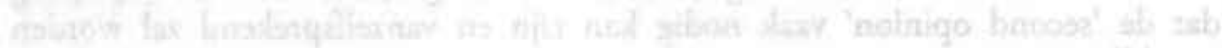

Thlicised

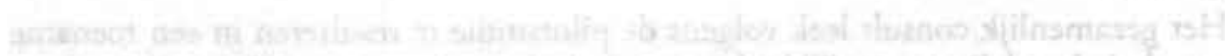

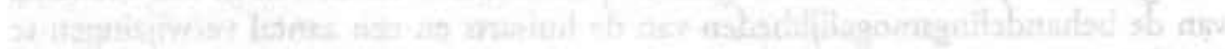

ax uoshom

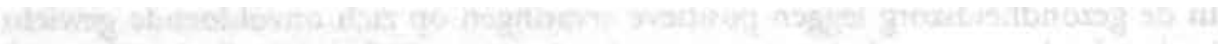

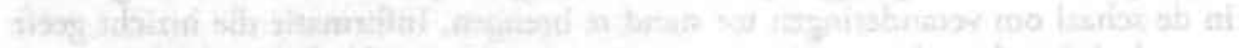

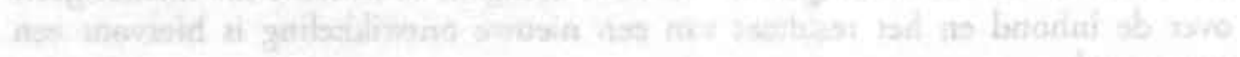

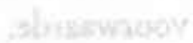

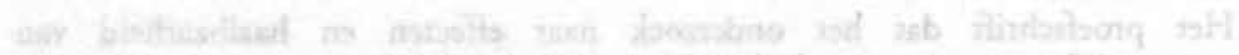

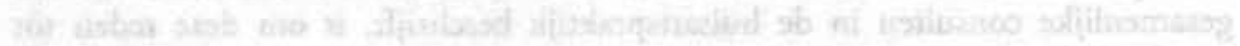

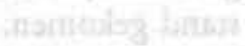




\section{Inhoudsopgave}

HOOFDSTUK 1

Inleiding en vraagstellingen

HOOFDSTUK 2

Onderzoeksopzet en methoden $\ldots \ldots \ldots \ldots \ldots \ldots \ldots \ldots \ldots \ldots \ldots$

$2.1 \quad$ Algemene opzet $\ldots \ldots \ldots \ldots \ldots \ldots \ldots \ldots \ldots \ldots \ldots$

2.2 Patiëntenpopulaties van de deelnemende huisartspraktijken (praktijkpopulaties) ................... 13

2.3 De huisartsen en orthopaedisch chirurgen ........... 13

2.4 Het prospectief gerandomiseerd onderzoek: de patiënteninstroom 15

2.4.1 In- en uitsluitingscriteria $\ldots \ldots \ldots \ldots \ldots \ldots \ldots \ldots \ldots$

2.4.2 Onderzoekspopulatie: aantallen patiënten .......... 15

2.4.3 Randomisatiemethode, -procedure en informed consent ..... 15

2.5 Gezamenlijke consult- en controlespreekuren . . . . . . . . 17

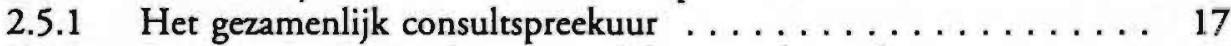

2.5.2 De organisatie van de gezamenlijke consultspreekuren . . . . . 17

2.5.3 Controleconsult (eindconsult) $\ldots \ldots \ldots \ldots \ldots \ldots \ldots \ldots \ldots$

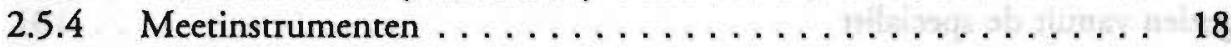

2.5.5 Statistische analyse methoden ............... 19

HOOFDSTUK 3

Het effectiviteitsonderzoek . . . . . . . . . . . . . 23

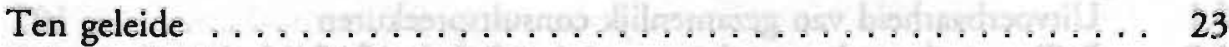

3.1 Patiënt- en klachtvariabelen ............... 24

3.1.1 Achtergrondgegevens, deelname, uirval en verwijsaantallen ... . 24

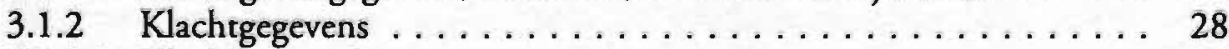

3.1.2.1 Klachtkenmerken .................... 28

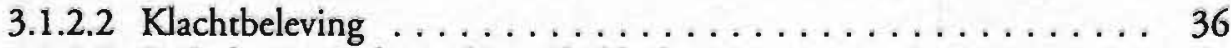

3.1.2.3 Pathologie gerelateerd aan de klacht ............. 41

3.1.2.4 Klacht en afwijkingen: vastgesteld door lichamelijk onderzoek . . 43

3.1.3 Co-morbiditeit . . . . . . . . . . . . . . . . . 48 
3.1.4 Ervaren algemene gezondheidstoestand . . . . . . . . 53

3.1.4.1 Lijst ervaren gezondheid $\ldots \ldots \ldots \ldots \ldots \ldots \ldots \ldots \ldots \ldots \ldots$

3.1.4.2 V.O.E.G.-Lijst $\ldots \ldots \ldots \ldots \ldots \ldots \ldots \ldots \ldots \ldots \ldots \ldots \ldots$

3.1 .5 Ervaren functioneren $\ldots \ldots \ldots \ldots \ldots \ldots \ldots \ldots \ldots \ldots$

3.1.5.1 Werken en activiteiten ................ 56

3.1.5.2 S.I.P. (Sickness Impact Profile) . . . . . . . . . . . . 57

3.1.6 Verwachtingen en ervaringen van pariënt en huisarts bij de hulpverlening $\ldots \ldots \ldots \ldots \ldots \ldots \ldots \ldots \ldots \ldots \ldots$

3.1.6.1 Wenselijkheid van verwijzing $\ldots \ldots \ldots \ldots \ldots \ldots \ldots \ldots$

3.1.6.2 Aandacht en satisfactie . . . . . . . . . . . . . 62

3.2 Proces-en zorgvariabelen (verrichtingen en verwijzingen) .....66 65

3.2.1 Behandeling voorafgaand aan de instroom ...........66

3.2.2 Consulten, verwijzingen en verrichtingen tijdens de

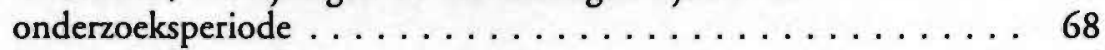

3.2.3 Kosten-baten analyse $\ldots \ldots \ldots \ldots \ldots \ldots \ldots \ldots \ldots \ldots 76$

HOOFDSTUK 4

Motieven, ervaringen en de deskundigheid van huisartsen bij het gezamenlijk consult . . . . . . . . . . . . . . . 87

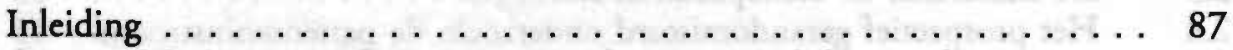

4.1 Motieven van huisartsen voor het gezamenlijk consult . . . . . . 87

4.2 Deskundigheidsbevordering ................ 91

4.3 Satisfactie van het gezamenlijk consult ........... 98

HOOFDSTUK 5

Informatieoverdracht, verwijsindicaties en behandelingsindicaties, gezien vanuit de specialist

HOOFDSTUK 6

Haalbaarheid van het gezamenlijk consult . . . . . . . . . 105

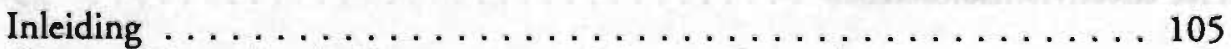

6.1 Uitvoerbaarheid van gezamenlijk consultspreekuren ....... 105

6.2 Peilingsonderzoek naar de gepercipieerde behoefte bij huisartsen aan her gezamenlijk consult $\ldots \ldots \ldots \ldots \ldots \ldots \ldots \ldots \ldots$ 
HOOFDSTUK 7

Ervaringen en opinies van huisartsen en orthopaedisch chirurgen

omtrent het gezamenlijk consult

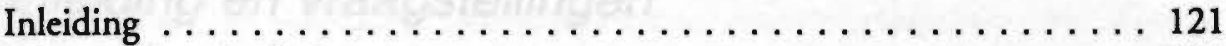

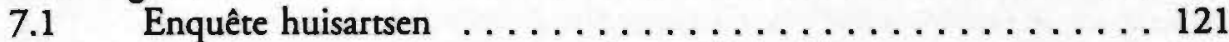

7.2 Enquête en ervaringen van orthopaedisch chirurgen $\ldots \ldots \ldots 122$

HOOFDSTUK 8

Beschouwingen en aanbevelingen

8.1 De opzet en uitvoering van het onderzoek .......... 125

8.2 Beschouwing met betrekking tot de bevindingen ........ 126

8.3 Betekenis van de bevindingen in relatie tot de literatuur ...... 131

8.4 Aanbevelingen ..................... 133

HOOFDSTUK 9

Samenvatting . . . . . . . . . . . . . . . 137

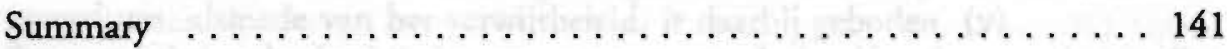

Dankwoord ......................... 145

Curriculum vitae $\ldots \ldots \ldots \ldots \ldots \ldots \ldots \ldots \ldots \ldots \ldots \ldots \ldots$

BIJLAGEN 


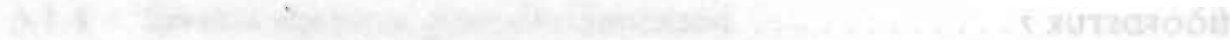

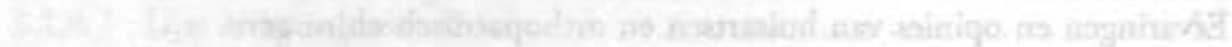

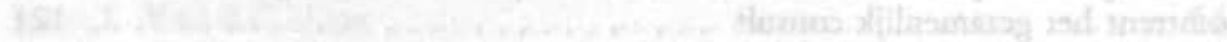

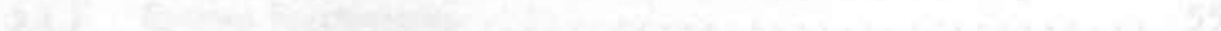

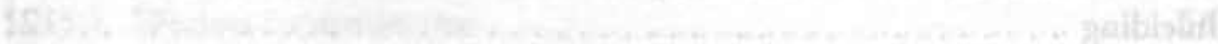
451.

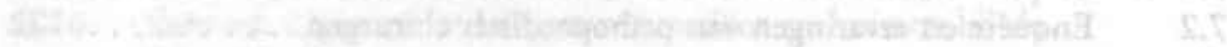
-

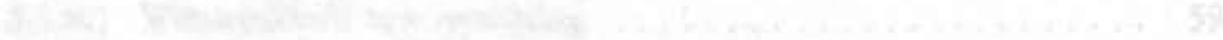

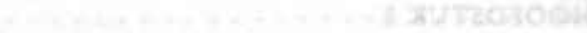

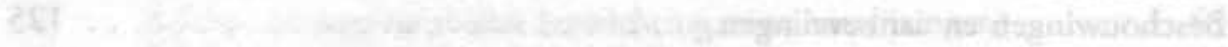

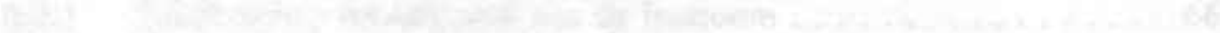

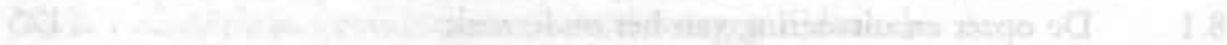

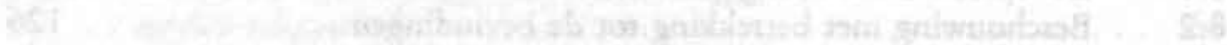
Wat.

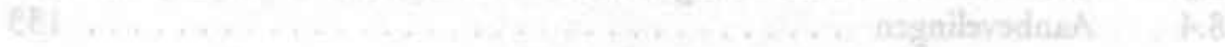

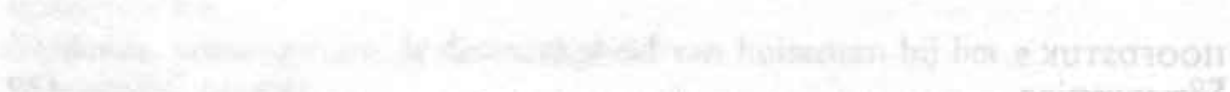

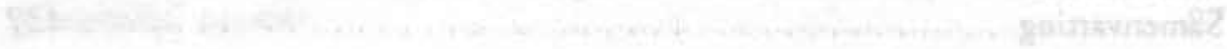

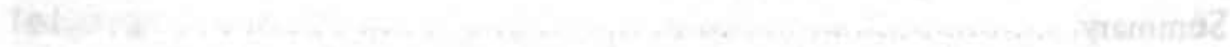
and

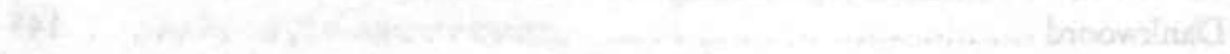

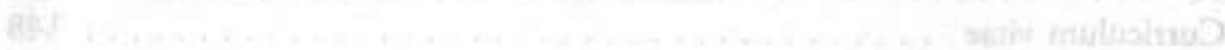

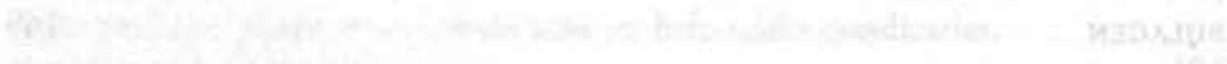
(12.2.

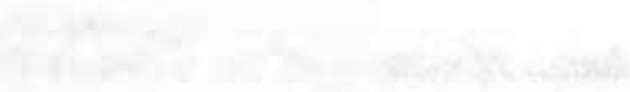

142017.

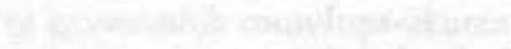




\section{Inleiding en vraagstellingen}

Huisartsen handelen vrijwel alle aangeboden klachten zelfstandig af. $(1,2)$

$\mathrm{Zij}$ beoordelen deze regelmatig $(10 \%)$ als 'moeilijk' en voelen zich daarbij dikwijls ontevreden over het verloop en het geplande beleid van het consult, hetgeen gevolgen kan hebben voor het al dan niet verwijzen. (3-5)

Het welslagen van een dergelijk consult is voor een belangrijk deel afhankelijk van de herkenning door de huisarts van de motieven van de patiënt* bij de betreffende hulpvraag en van de mogelijkheid een adequaat antwoord te kunnen geven op motieven en hulpvraag. (6) In het algemeen is de beschikbaarheid van relevante informatie over de patiënt daarbij van groot belang voor de kwaliteit van de zorg. $(7,8)$ Naast kwaliteit van zorg speelt doelmatigheid in de zorg een belangrijke rol. Kritische evaluatie van routinematige diagnostische en therapeutische standaardprocedures, alsmede van het verwijsbeleid, is daarbij geboden. (9)

De verwachting is daarbij dat artsen voor een deel zelf orde op zaken zullen stellen en onder andere de samenwerking tussen huisartsen en specialisten zullen intensiveren. Substitutie van zorg wordt gezien en lijkt haalbaar als één van de mogelijke oplossingen. (10-12)

Verwijscijfers hebben in dit verband van beleidmakers en onderzoekers steeds veel aandacht gekregen. (13-16)

Het terugdringen van de hoogte van het gemiddelde verwijscijfer is een belangrijke graadmeter van het op substitutie gericht beleid. $(17,18)$

Bij veel studies met ofwel kwaliteitsverbetering of kostendaling als doel zag men veelal beide gelijktijdig optreden. (19)

Volgens Mokkink (2) verwijzen 'veel verwijzers' vooral meer patiënten met 'selflimiting' aandoeningen, terwijl verwijzen eigenlijk bedoeld is voor klachten waarbij de huisarts niet of niet meer bevredigend kan behandelen. (20)

Huisartsen met meer specifieke ervaring bleken echter ook meer te verwijzen, omdat zij veel belang hechten aan specialistisch onderzoek. (21)

Felson c.s. concludeerden dat het merendeel van de klachten met betrekking tot het bewegingsapparaat zelfstandig door huisartsen te behandelen zou zijn. (22) Binnen hun 'poortwachtersfunktie' hebben huisartsen de taak patiënten te beschermen tegen mogelijke overbehandeling. (23-27)

\footnotetext{
* Waar in de rekst wordr geschreven over de patiënt of de huisarts en deze in de mannelijke vorm (hem of zijn) wordt angeduid, is dit gedaan om louter stilistische redenen.
} 
Doordat huisartsen via hun verwijsbeleid in aanzienlijke mate de samenstelling van het patiëntenbestand van specialisten bepalen, hebben zij een belangrijke invloed op de specialistische zorg. $(27,28)$

Ook van de zijde van de specialisten wordt melding gemaakt van onnodige verwijzingen, verwijzingen waarbij door de patiënten veel 'druk' was uitgeoefend, onvoldoende samenwerking in de gezondheidszorg en een te verwachten belangrijke stijging van het aantal verwijzingen in de toekomst. (29-31)

Deze problematiek wordt versterkt door lange wachtlijsten en chronische klachten, terwijl voor laatstgenoemde klachten ook huisartsen vaak geen succesvolle behandelwijze ter beschikking hebben. Een deel van de verwijzingen geschiedt als gevolg van 'defensief handelen'. $(4,5)$

Gerritsma en Smal pleiten om bij die patiënten, waarbij een adequate diagnose en beleid een punt van discussie is, patiëntbesprekingen te houden, zowel in het eerste en tweede echelon, als tussen beide echelons. (32)

Gestructureerde samenwerking lijkt op het gebied van verwijzen, naast initiatieven als 'consultkaart' en 'NHG Standaard verwijsbrief, oplossingen te bieden. (33-35)

Voor de kwaliteitsverbetering van de gezondheidszorg werd meer verwacht van het vinden van oplossingen voor de problemen op het gebied van de communicatie en samenwerking, dan van de verdere uitbreiding van kennis en mogelijkheden op het medisch technisch terrein. $(6,36-40)$

Van Es meent dat de wederzijdse wens en wil voor een goede samenwerking bij huisartsen en specialisten daarvoor de meest essentiële voorwaarde is. $(6,37)$

Als bijdrage voor de oplossing voor bovenstaande problemen en met het doel een kwalitatief betere en meer doelmatige zorg te kunnen verlenen is gebruikt gemaakt van de werkwijze van het gezamenlijk consult in de huisartspraktijk.

Consultatie betekent volgens Carne en Post 'dat er overleg tussen twee deskundigen plaats vindt, waarbij de verantwoordelijkheid helemaal bij de consultatievrager ligt'. $(40,41)$

Bij het gezamenlijk consult zien de consultatiegever (specialist) en de consultatievrager (huisarts) samen de patiënt, waarbij tot aan het moment van een eventuele verwijzing, de verantwoordelijkheid bij de consultatievrager ligt.

Het doel van het gezamenlijk consult betreft deskundigheidsbevordering, het voorkomen van onnodige verrichtingen en verwijzingen, gerichter verwijzen en het verbeteren van communicatie tussen huisarts en specialist. $(41,42)$.

Elders werd deze werkwijze, waarbij een vaste groep huisartsen en specialisten regelmatig bijeenkwamen eveneens toegepast en beschreven. (43-54)

De werkwijze lijkt te beantwoorden aan een aantal door Meyboom-de Jong voor de begeleiding van met name oudere patiënten essentieel geachte aspecten van de huisartsgeneeskunde, namelijk; gebruik van contextuele informatie, kennen van co-morbiditeit, zorg voor continuïteit en aandacht voor communicatie tussen de verschillende behandelaars. (55)

Het volgens Long en Atkins bestaande grote verschil tussen behoefte aan en het werkelijk uitgevoerd overleg tussen huisartsen en specialisten over hun pariënten kan door deze werkwijze afnemen. (56) 
Consultatie-ervaringen vanuit verpleegtehuizen en voor specifieke groepen patiënten werden eveneens geëvalueerd. $(57,58)$

Uit de diverse ervaringen komt naar voren dat het gezamenlijk consult wordt gevolgd door een betere samenwerking tussen huisarts en specialist, met afname van het aantal verwijzingen, verbetering van de deskundigheid van de huisartsen en dientengevolge het optreden van een substitutie-effect.

De belemmeringen bij gemotiveerde huisartsen en specialisten bestonden voornamelijk uir tijdgebrek en ontbreken van honorering.

Ook met telefonische consultaties als vorm van nascholing en als diagnostisch hulpmiddel werden positieve ervaringen opgedaan. $(59,60)$

Vooral in Engeland is onderzoek verricht naar de behoefte aan en motieven bij consultaties van specialisten aan huis van de patiënt.

De behoeften liepen hierbij sterk uiteen voor de verschillende specialismen. In een aantal gevallen nam het gezamenlijk contact van de huisarts met de specialist en de patiënt (61-64) vanwege de volgende redenen af:

De huisartsen vonden geen tijd voor de contacten; dachten geen advies nodig te hebben; gebruikten de contacten vooral om opnamen te forceren (wachtlijsten te ontlopen); bemerkten geen duidelijk nascholingseffecten; hadden een afkeer voor het herhalen van onderzoek; en werden er niet voor gehonoreerd. $(50,51)$

Geconcludeerd kan worden dat in het gezamenlijk consult een aantal doelen nagestreefd worden, welke mogelijk belangrijke effecten op kunnen leveren in een gezondheidszorg waar doelmatigheid en communicatie in toenemende mate knelpunten vormen.

In het licht van het voorgaande worden de kenmerken van het Maastrichtse project 'Gezamenlijk Consult' als volgt beschreven:

\section{DOELSTELLING}

Beoogd wordt huisartsen met deze werkwijze de mogelijkheid te bieden patiënten zelf optimaal te behandelen of indien nodig gericht en effectief te verwijzen. Het te bereiken doel houdt in dat er minder verwijzingen en verrichtingen plaatsvinden, substitutie van zorg van de tweede lijn naar de eerste lijn wordt gerealiseerd bij een meer doelmatige en meer gerichte wijze van zorg, terwijl er een kennisvermeerdering en toename en/of verbetering van vaardigheden ontstaat bij de deelnemende huisartsen.

De subjectieve en objectieve gezondheidstoestand van de op deze wijze behandelde patiënten dient na behandeling via het gezamenlijk consult minstens gelijk te zijn aan die van de op de gebruikelijke wijze behandelde patiënten.

Om na te gaan in hoeverre de na te streven doelen haalbaar en toetsbaar zijn, is gekozen voor een onderzoeksopzet middels het project 'Gezamenlijk Consult huisarts-specialist in de huisartspraktijk, voor problemen met betrekking tor het bewegingsapparaat'. 
Gekozen is voor klachten van het bewegingsapparaat en voor het specialisme orthopaedie. Hierbij speelde een aantal motieven een rol. Uit registratiegegevens blijkt dat klachten op het gebied van het bewegingsapparaat de omvangrijkste categorie vormen van de aan huisartsen gepresenteerde morbiditeit.

Een belangrijk deel van deze klachten is langdurig aanwezig, complex van aard en niet levensbedreigend. (65-69)

Bovendien voelen huisartsen zich bij verwijzingen naar orthopaedie vaak onder druk gezet. (29)

Huisartsen worden, ook op het gebied van het bewegingsapparaat, diverse malen geconfronteerd met verzoeken voor verwijzing, waarvan zij de zin niet inzien. (29)

Het is zeer wel mogelijk dat een substantieel deel van de doorgaans naar orthopaedisch chirurgen verwezen patiëntenpopulatie adequaat door huisartsen kan worden behandeld. $(22,70)$

Technisch hoogwaardige apparatuur voor diagnostiek en behandeling, evenals operatieve behandelingen, zijn tevens slechts bij een klein deel van de thans verwezen patiënten geïndiceerd.

Lacunes op het gebied van het bewegingsapparaat in de opleiding tot arts en huisarts veroorzaken waarschijnlijk een zodanig kennis- en vaardighedenniveau bij huisartsen, dat een aantal patiënten onnodig wordt verwezen.

Ter voorkoming van somatische fixatie kan het van belang zijn, dat huisartsen, zonodig samen met specialisten, deze patiënten optimale duidelijkheid verschaffen omtrent de klacht, indien nodig op het juiste moment verwijzen en waar mogelijk zelf blijven behandelen. (71)

Intensieve samenwerking, zoals gerealiseerd in het gezamenlijk consult, kan daarbij voor zinvolle praktijkgerichte nascholingseffecten zorgen.

Een pilotstudy in enkele gezondheidscentra, waar het gezamenlijk consult met orthopaedisch chirurgen plaatsvond, liet positieve resultaten zien. $(43,44)$

In het bijzonder gold dat de orthopaedisch chirurgen gemotiveerd waren om aan een dergelijk project deel te nemen, hetgeen er toe leidde, dat de vakgroep Orthopaedie van het Academisch Ziekenhuis Maastricht en de Rijksuniversiteit Limburg haar medewerking roezegde.

Bij het onderzoek naar de haalbaarheid en de effecten van het gezamenlijk consult zijn de volgende vragen gesteld:

VRAAGSTELLINGEN

vraag 1

Zijn gezamenlijke consultspreekuren organisatorisch goed uitvoerbaar?

Is er een voldoende aanbod van patiënren om regelmatig spreekuren te plannen en hoe verloopt het patiëntenaanbod? 


\section{vraag 2}

Welke zijn de effecten van het gezamenlijk consult bij klachten van het bewegingsapparaat voor patiënten, huisartsen en specialisten?

\section{vraag 3}

Is het mogelijk een deel van de patiënten met klachten waarvoor zij normaliter naar de polikliniek orthopaedie worden verwezen, met behulp van het gezamenlijk consult, door huisartsen adequaat te laten behandelen en zo ja, voor welk type klachten respectievelijk patiënten is dat het geval?

\section{vraag 4}

Welke motieven hebben huisartsen wanneer zij patiënten geschikt achten voor een gezamenlijk consult?

\section{vraag 5}

Ontstaat bij huisartsen die deelnemen aan het gezamenlijk consult een toename van kennis en een verbetering van de vaardigheden?

\section{vraag 6}

Welke ervaringen doen orthopaedisch chirurgen op wanneer zij deelnemen aan het gezamenlijk consult?

DE VRAAGSTELLINGEN ZIJN GEOPERATIONALISEERD DOOR DE VOLGENDE VRAGEN:

ten aanzien van de organisatie: (vraag 1 )

- Is voor patiënten, huisartsen en orthopaedisch chirurgen de organisatie van gezamenlijke consultspreekuren haalbaar en uitvoerbaar?

- Welke is de behoefte bij huisartsen aan het gezamenlijk consult voor klachten van het bewegingsapparaat, en bestaan er verschillen tussen de groepen huisartsen?

- Hoe verloopr de behoefte aan her gezamenlijk consult bij huisartsen, die regelmatig deelnemen aan gezamenlijke consultspreekuren?

ten aanzien van de klachten en patiënten: (vragen 2 en 3)

- Welk type klachten, gespecificeerd naar klachtkenmerken en klachtbeleving gerelateerd aan pathologie, co-morbiditeit, life-events en voorgeschiedenis, wordt voor het gezamenlijk consult gepresenteerd, en in hoeverre komen de klachten overeen met de klachten waarmee patiënten naar de polikliniek orthopaedie worden verwezen?

- Hoe is de lichamelijke toestand, het subjectief en objectief welbevinden, de ervaringen ten aanzien van het functioneren en sarisfactie ten aanzien van de zorgverlening van de patiënten die deelnemen aan het gezamenlijk consult, vergeleken met die van patiënten welke op de gebruikelijke wijze worden behandeld?

- Hoe verhouden de verrichtingen en verwijzingen van de groep patiënten die deelneemt aan het gezamenlijk consult zich ten opzichte van die van een 
vergelijkbare groep patiënten welke op de gebruikelijke wijze wordt behandeld? Zijn er klacht- en/of patiëntencategorieën waarvoor het gezamenlijk consult al of niet opvallend effectief is?

- Wanneer patiënten na een gezamenlijk consult worden verwezen gebeurt dit, vergeleken met de gebruikelijke zorg, al of niet op een later tijdstip na de instroom?

- In welke mate en op welke wijze speelt de wens/verwachting tot verwijzing een rol bij de verwijzingen van patiënten voor het gezamenlijk consult?

- Is een kosten-effectiviteitsanalyse van het gezamenlijk consult op te stellen en welke zijn daarvan de uitkomsten?

ten aanzien van de huisartsen en de orthopaedisch chirurgen: (vragen $2,4,5$ en 6)

- Welke motieven hebben huisartsen bij patiënten die zij geschikt achten voor een gezamenlijk consult en in hoeverre komen de verschillende motieven voor bij de verwijzingen?

- Ervaren huisartsen die deelnemen aan het gezamenlijk consult, vergeleken met niet deelnemende huisartsen, een toename van kennis en verbetering van vaardigheden en is dat vast te stellen?

- Voldoet het gezamenlijk consult aan de verwachtingen die huisartsen vooraf daarover hadden?

- Welke zijn de ervaringen die orthopaedisch chirurgen opdoen als consulenten tijdens het gezamenlijk consult?

\section{OPZET VAN HET PROEFSCHRIFT}

Waar het gezamenlijk consult in de huisartspraktijk voor klachten van het bewegingsapparaat een in de gezondheidszorg nieuw te introduceren wijze van samenwerken betreft, is gekozen voor een onderzoek naar de effecten van het gezamenlijk consult, alsmede voor een onderzoek naar de haalbaarheid van en behoefte er aan in de huisartspraktijk.

In het proefschrift worden achtereenvolgens de volgende onderwerpen beschreven:

- onderzoeksopzet met toegepaste methodologie

- effectiviteitsonderzoek in een twaalftal huisartspraktijken in Maastricht en Meerssen

- deskundigheidsbevordering van de huisartsen

- informatieoverdracht naar de specialist

- haalbaarheid van het gezamenlijk consult

- ervaringen van huisartsen en specialisten

- beschouwingen en aanbevelingen

- samenvatting. 


\section{Literatuur}

1 Does van den E. Goed verwijzen. MC 1979;34:225

2 Mokkink HGA. Ziekenfondscijfers als parameter over het handelen van huisartsen. Proefschrift Nijmegen KUN 1986.

3 Beukema-Siebenga H. Ontevredenheid over het patiënt contact. Huisarts Wet 1991; 34(4):166-8.

4 Beukema-Siebenga $\mathrm{H}$. Arts-patiënt contacten in zeven huisartspraktijken. Huisarts Wet 1990;33:92-5.

5 Lamberts H, Janssens PMH. Defensief handelen door huisartsen. Ned Tijdschr Geneeskd 1984;128(13):598-602.

6 Es JC van. Patiënt, huisarts en specialist op één lijn. MC 1984;42:1357-9.

7 Starfield B, Steinwachs D et al. Concordance Berween Medical Records and Observations Regarding Information on Coordination of Care. Med Care 1979;17:758-66.

8 Verhaak PFM. Hoe speciaal is de communicatie van de huisarts? Huisarts Wet 1991; $34(7): 320-4$.

9 Borst-Eilers E. Kiezen in de gezondheidszorg. MC 1990;51/52:1533-4.

10 Tits MHL van. Substitutie. MC 1988;19:585-8.

11 Groenewegen PP. Verrichtingen in de huisartspraktijk. MC 1990;19:608-11.

12 Wennink J, Goudriaan G. De eerste lijn en thuiszorg. MC 1990;37:1081-5.

13 Marinker M, Wilkin D, Mercalfe DH. Referral to hospital, can we do better? Br Med J 1988;297:461-4.

14 Roland M. General practitioner referral rates. Interpretation is difficult. Br Med J 1988;297:437-8.

15 Wilkin D, Smith A. Variation in general practitioners' referral rates to consultants. J R Coll Gen Pract 1987;37(301):350-3.

16 Wilkin D. Smith A. Explaining variation in general practitioner referrals to hospital. Fam Pract 1987:4(3):160-9.

17 Wijkel D, Zee J van de, Bahler D de. Ziekenfondscijfers van samenwerkende huisartsen. TSG 1992;70:519-26.

18 Discussienota substitutie in de gezondheidszorg. Zoetermeer: Nationale Raad voor de Volksgezondheid 1989.

19 Ven WPMM van de, Winkers CGF, Wohrmann LJE. Doelmatigheid in de gezondheidszorg: een miljardenkwestie. Ned Tijdschr Geneeskd 1988;132(35):1623-7.

20 Knottnerus JA, Vet HCW de. Effectiviteitsonderzoek in de huisartspraktijk. Huisarts Wet 1987;30:49-53.

21 Reynolds GA, Chitnis JG, Roland MO. General pracritioner outpatient referrals: do good doctors refer more patients to hospital? Br Med J 1991;302:1250-2.

22 Felson DT, Meenan RF, Dayno SF, Gertman P. Referral of musculoskeletal disease parients by family and general practitioners. Archritis-Rheum 1985;28(10):1156-62.

23 Franks P, Clancy CM, Nutting PA. Gatekeeping revisited-protecting patients from overtrearment. N Engl J Med 1992;327(6):424-9.

24 Basis-takenpakket van de huisarts. Utrecht: LHV 1982.

25 Meyboom WA. Schaadt overdaad in de (huisarts)geneeskunde? The Practitioner 1991; 8:568

26 Post D. Iatrogene ziekren: een onderzoek naar oorsprong en omvang. Alphen a.d. Rijn: Stafleu 1984.

27 Knottnerus JA. Medical decision making by general practitioners and specialists. Fam Practice 1991;8:305-7. 
28 Kersten TJJMT. De invloed van de huisarts op de specialist. TSG 1992;70:171-9.

29 Armstrong D, Try J, Armstrong P. Doctor's perceptions of pressure from patients for referral. Bir Med J 1991;302:1186-8.

$30 \mathrm{Krol} \mathrm{LJ}$. De consument als leidend voorwerp in de gezondheidszorg: onderzoek naar achtergronden en verwijzingen naar de kinderarts. Proefschrift Universiteit van Amsterdam 1985.

31 Christensen B, Sorensen HT, Mabeck CE. Referral from general practice to dermatologists. Scand J Prim Health Care 1988;6(1):29-32.

32 Gerritsma. JGM, Smal JA. De werkwijze van huisarts en internist: een vergelijkend onderzoek met behulp van een interactieve patiëntensimulatie. Utrecht: Bunge 1982.

33 Casparie F. Gestructureerde Samenwerking. MC 1985;40:97-100.

34 Nuynen W, Slobbe W van. Een haalbare kaart. MC 1988;10:301-5.

35 Sips AJBI, Smeele I, Voort JPM van der. De verwijsbrief naar de tweede lijn. NHGstandaard. Huisarts Wet 1989;32:541-4.

36 Pop P. Consultaties $1^{\circ}-2^{\circ}$ lijn. Drie jaar Diagnostisch Centrum Maastricht. MC 1982; 37:1019-23.

37 Es JC van. Integratie: voor huisarts en specialist een zorg. MC 1990;51/52:1536-7.

38 Swinkels MAA, Dopheide JP. Samenwerking tussen $1^{\circ}-2^{\circ}$ lijnsgezondheidszorg te Hoogeveen, Utrecht: NHI 1982.

39 Hamers RTJ c.s. Samenwerking na verwijzing. MC 1991;26:817-9.

40 Post D. Verwijzen en prescriptie, een paar apart. Zwolle: Regionaal Ziekenfonds Zwolle 1984.

41 Carne S. A problem halved? J R Coll Gen Pract 1981;32:10

42 Schuurman W, Everdingen JJE van, Schadé E. De dermatoloog in de eerste lijn. Huisarts Wet 1992:35(4):161-3.

43 Vierhout WPM, Beusmans GHMI, Verwijnen GM, Ooij A van, Gasselt HRM van, Beek JMH van der. Gezamenlijk Consult huisarts-specialist. MC 1987;4:106-9.

44 Ooij A van, Walenkamp GHIM, Geesink RGT, Arens HJ, Vierhour WPM, Knotrnerus JA. Consultatie in de huisartspraktijk; een specialistische impressie. MC 1992;4:118-20.

45 Have J ten, Buwalda J. Hoe her beter kan russen huisarts en specialist. MC 1990; 45:86-8.

46 Have JJIM ten, Kolker L. Consultarievormen Huisarts-Specialist. O en O 1989.

47 Hall EV van, Gill K, Trimbos JB. Gynaecologische consultaties in de huisartspraktijk. MC 1987;4:105-6.

48 Burkens JCJ. Consultaties in beide richtingen. MC 1974;29:705-14.

49 Mulder JD. Somatische Consultatie. Tijdschrift SDO dec. 1987:18-20.

50 Smit DJ de. Consultatiebijeenkomst voor huisartsen en specialisten: projekt samenwerking $1^{\circ}-2^{\circ}$ lijn. Amsterdam VU Ziekenhuis: projekt samenwerking $1^{\circ}-2^{\circ}$ lijn 1989.

51 Smit DJ de. Consultatie tussen huisarts en specialist. MC 1987;42:849-52.

52 Smit DJ de c.s. Ervaringen met consultatiebijeenkomsten. MC 1990;47:1413-15.

53 Norell L.JS. Consultant sessions in health centres and group practices. Community Health 1975;6:306-10.

54 Grinten R van der. Communicatie huisarts-internist. MC 1981;36:777-81.

55 Meyboom-Jong de B. De oudere patiënt in beeld. Huisarts Wet 1991;34(2):82-8.

56 Long A, Atkins JB. Communications between General Practitioners and consultants. $\mathrm{Br}$ Med ] 1974; $4: 456-9$.

57 Wersch-Spek MCM van de. De verpleeghuisarts als medisch consulent in de eerstelijns gezondheidszorg. MC 1987;39:1243-4.

58 Wouden JC van der, Dokter HJ. Samenwerking tussen huisarts en specialist bij patiënten met kanker. Huisarts Wet 1989;32(2):51-5. 
59 Pop P, Beusmans GHMI. Telefonische consultatie als diagnostisch hulpmiddel. The Practirioner 1990;635-8.

60 Plantenga HA. Het telefonisch consult als nascholingsvorm. MC 1986;41:47

61 Fry J, Sandler G. Domiciliary consultations: some facts and questions. Br Med J 1988; 297(6644):337-8.

62 Littlejohns PC. Domiciliary consultations - who benefits? JR Coll Gen Pract 1986; 36(288):313-5.

63 Coupland AI, Todd GB. Pattern of domiciliary consultations in the Trent region. Br Med J 1985;290(6479):1399-402.

64 Mullery GP. Home visiting by consultants. Br Med J 1988;296:515-6.

65 Höppener P, Knotmerus JA, Metsemakers JFM, Kocken RJJ, Limonard ChBG. Het Registratienet Huisartspraktijken van de Rijksuniversiteit Limburg. Huisarts Wet 1990; 33(2):66-69.

66 Lamberts $H$, Brouwer $H$, Groen ASM, Huisman H. Het transitiemodel in de huisartspraktijk. Huisarts Wet 1987;30:105-13.

67 Lamberts $H$. Aan de diagnose gebonden informatie uit de huisartspraktijk; van een op de prevalentie naar een op de episode beoriënteerde epidemiologie. Ned Tijdschr Geneeskd 1986; 130:292-6.

68 Weel O van, Bosch WJHM van den, Hoogen HJM van den. De Continue Morbiditeits Registratie Nijmegen. Huisarts Wet 1986;29:373-7.

69 Lamberts $H$. De morbiditeitsanalyse 1972 door de groepsprakrijk Ommoord. Huisarts Wet 1974;17:455-73, Huisarts Wet 1975;18:7-39, Huisarts Wet 1975;18:61-72.

70 Ross AK, Davis WA, Horn G, Williams R. General practice orthopaedic ourpatient referrals in North Sraffordsire. Br Med J 1983;287:1439-41.

71 Kuyvenhoven MM, Jacobs HM, Touw-Otten FWMM, Fs JC van. Verschillen in hulpverlening bij patiënten met vage klachten. Huisarts Wet 1986;29(3):65-71. 


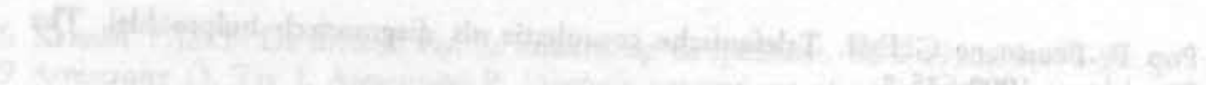

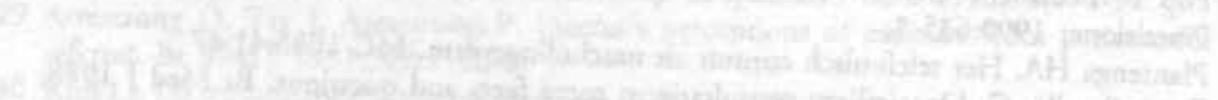

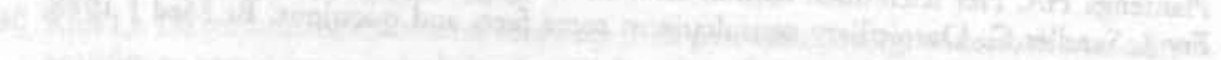

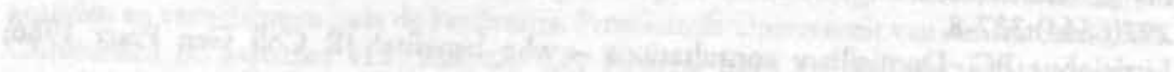

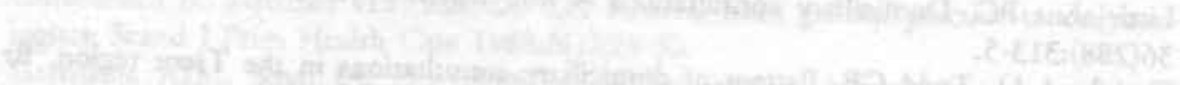

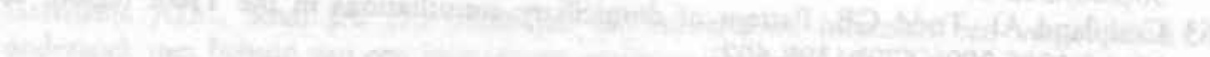

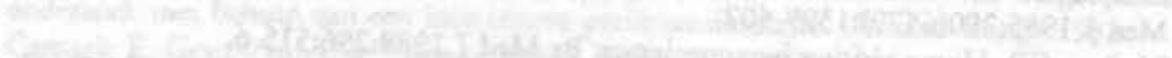
Wo

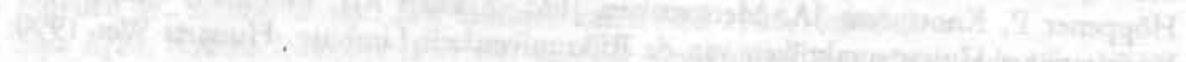
Q

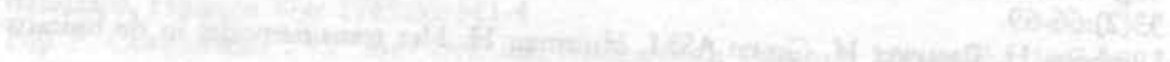

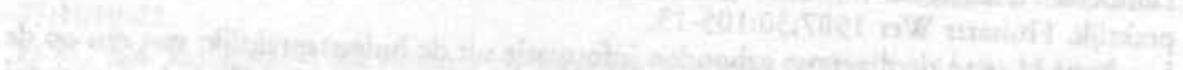

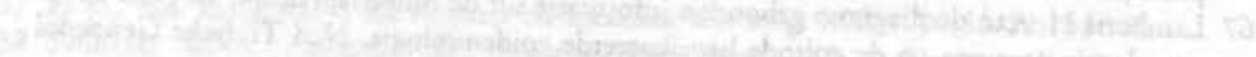

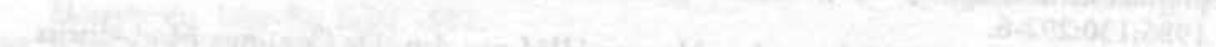

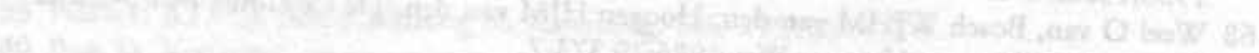

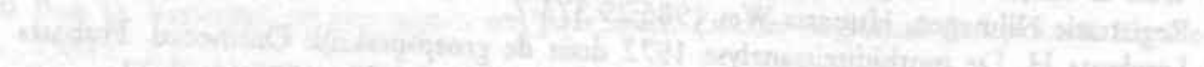

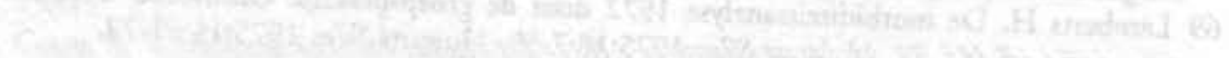
14:-

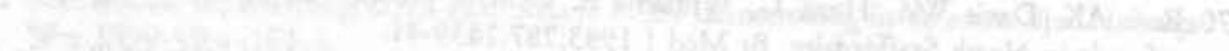

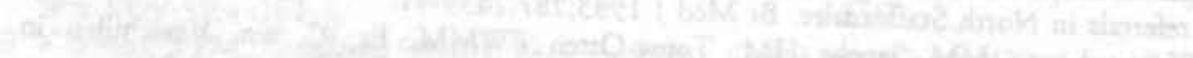

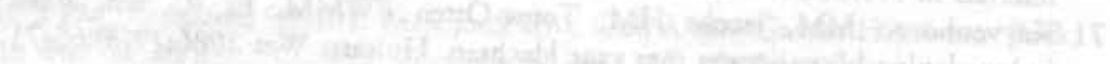

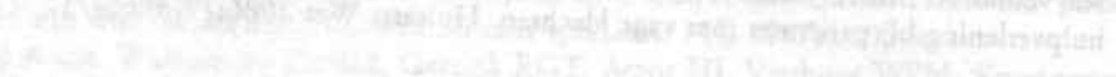




\section{Onderzoeksopzet en methoden}

\subsection{Algemene opzet}

In dit hoofdstuk wordt eerst de globale onderzoeksopzet van het effectiviteitsonderzoek en van het peilingsonderzoek beschreven. Vervolgd wordt met de patiëntenpopulaties van de huisartspraktijken die aan het effectiviteitsonderzoek deelnamen, waarna informatie wordt gegeven over de huisartsen en orthopaedisch chirurgen die aan het onderzoek deelnamen. Tenslotte worden de elementen van het prospectief gerandomiseerde onderzoek beschreven.

Het onderzoeksproject bestond uit een tweetal onderdelen:

1. Een prospectief gerandomiseerd onderzoek naar haalbaarheid en effecten van gezamenlijke consultspreekuren in de huisartspraktijk. Naast effecten met betrekking tot subjectieve en objectieve gezondheidstoestand en medische consumptie, werd ook het kennis- en vaardighedenniveau van huisartsen die deelnemen aan gezamenlijk consultspreekuren bestudeerd.

\section{KORTE INHOUD}

Om effecten (het effectiviteitsonderzoek) en haalbaarheid (het haalbaarheidsonderzoek) van gezamenlijke consultspreekuren te meten, is gekozen voor een gerandomiseerde onderzoeksopzet. $(1,2)$

Een twaalftal huisartsen, verdeeld in vier groepen, werd de mogelijkheid geboden om samen met een orthopaedisch chirurg in de spreekkamer van één van de huisartsen regelmatig spreekuren te houden voor patiënten met klachten van het bewegingsapparaat.

Patiënten, volgens de huisartsen geschikt geacht voor een gezamenlijk consult, werden gerandomiseerd in twee groepen, een interventiegroep, die daadwerkelijk gezien werd tijdens het gezamenlijk consult, en een controlegroep, die de gebruikelijke behandeling kreeg (zie figuur 2.1.I).

Van beide groepen werd een aantal onderzoeksgegevens verzameld, terwijl vervolgens alle verrichtingen welke verband hielden met de ingangsklacht gedurende één jaar werden geregistreerd. $\mathrm{Na}$ dit jaar werden alle patiënten van beide groepen uirgenodigd voor een controle-onderzoek door een orthopaedisch chirurg. 
Figuur 2.1.I

\section{PROJECTOPZET}

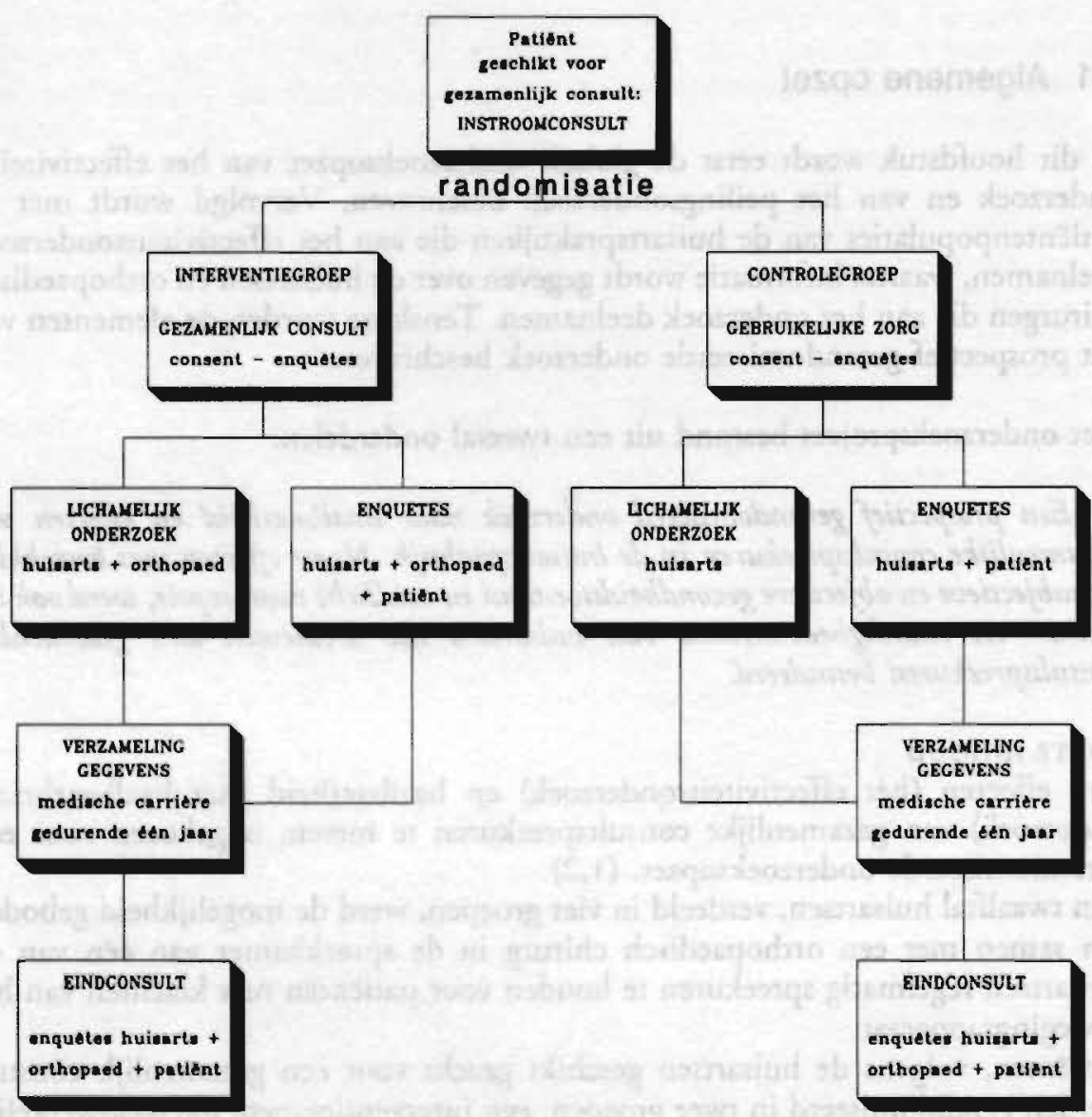

De aan het effectiviteitsonderzoek deelnemende huisartsen werden, evenals een controlegroep huisartsen, door middel van een vragenlijst over klachten van het bewegingsapparaat bij de start en aan het eind van het onderzoek getoetst (het onderzoek naar deskundigheidsbevordering), om na te gaan in hoeverre het 
gezamenlijk consult een invloed had op het kennis- en vaardighedenniveau van de deelnemende huisartsen.

Aan de aan het onderzoek deelnemende huisartsen werd bij de eindconsulten gevraagd of zij na het instroomconsult patiënten met identieke klachten hadden gezien en zo ja, of zij deze patiënten al dan nier hadden verwezen en met welke motieven. De huisartsen en orthopaedisch chirurgen werden aan het eind van het project geënquêteerd over hun ervaringen.

\section{Een peilingsonderzoek naar de behoefte bij huisartsen aan het gezamenlijk consult.}

\section{KORTE INHOUD}

Een peilingsonderzoek werd verricht naar de behoefte aan het gezamenlijk consult. Daartoe werden de huisartsen uit de regio Heuvelland, nadat zij informatie hadden ontvangen over het doel en de gang van zaken van het gezamenlijk consult, gevraagd of zij meenden dat een gezamenlijk consult een zinvolle werkwijze zou zijn geweest bij recent door hen naar de polikliniek orthopaedie verwezen patiënten. Daarbij werd door de verwijzende huisarts een aantal klachtkenmerken en motieven met betrekking tot de recent verwezen patiënt geregistreerd. Deze gegevens werden vergeleken met instroomgegevens van het effectiviteitsonderzoek.

Het peilingsonderzoek wordt beschreven in paragraaf 6.2 .

\subsection{Patiëntenpopulaties van de deelnemende huisartspraktijken (praktijkpopulaties)}

De praktijkpopulaties van de aan het effectiviteitsonderzoek deelnemende huisartsen in Maastricht en Meerssen vormden de doelgroep. Van deze populatie was $67 \%$ bij het ziekenfonds verzekerd.

De leeftijdsverdeling en het verwijzingspatroon (orthopaedie en algemeen) van de ziekenfondsverzekerden kwamen goed overeen met die in de regio Heuvelland (Maastricht en omgeving), (zie bijlage 12). (3)

Overigens zijn er geen argumenten of aanwijzingen waarom het voorkomen van klachten van het bewegingsapparaat in deze populatie zou afwijken van de populatie van de regio.

\subsection{De huisartsen en orthopaedisch chirurgen}

Ervaringen met consultaties en het gezamenlijk consult in de huisartspraktijk bestonden vooral bij gezondheidscentra.

In Nederland werd de huisartsgeneeskunde in 1988 voor $63 \%$ uitgeoefend door solistisch werkende huisartsen, voor $31 \%$ door huisartsen in groepspraktijken en voor $6 \%$ door huisartsen, werkzaam in gezondheidscentra. (3) 
Om een uitspraak te kunnen doen over de haalbaarheid van het gezamenlijk consult voor huisartsen in het algemeen, was het van belang om zowel solistisch werkende als samenwerkende huisartsen aan het onderzoek te laten deelnemen. Omdat de deelname van de orthopaedisch chirurgen beperkt was tot die van het Academisch Ziekenhuis Maastricht, namen uitsluitend huisartsen uit Maastricht en omgeving aan het onderzoek deel.

We verwachtten met vier groepen van drie huisartsen de voor het onderzoek noodzakelijke aantallen patiënten binnen één jaar te kunnen insluiten. (zie paragraaf 2.4.2.).

Uit contacten met huisartsen in de regio bleek dat er grote belangstelling bestond voor deelname aan het gezamenlijk consultproject.

Het tijdstip waarop huisartsen meedeelden te willen deelnemen werd als keuzecriterium gehanteerd voor deelname.

Een drietal gezondheidscentra kon niet deelnemen wegens eerdere participatie aan de pilotstudy.

De huisartsgroepen waren als volgt samengesteld:

- én groep, (groep I), bestaande uit drie in een groepspraktijk werkende huisartsen, te Maastricht.

- twee groepen, (groep II en IV), elk samengesteld uit drie binnen én maatschapsvorm werkende solisten, in Meerssen

- én groep, (groep III), gevormd door een maatschap van twee huisartsen en een solistisch werkende buurtcollega, in Maastricht.

Tijdens het project heeft zich bij een huisartsgroep, door vestiging van én van de huisartsen elders, een mutatie voorgedaan. De mutatie in deze groep leidde er toe dat in de periode van september 1989 tot en met maart 1990 vrijwel geen gezamenlijke consulten plaatsvonden.

Een andere deelnemende huisarts vond de administratieve werkzaamheden behorend bij het project te belastend, reden waarom hij zijn deelname aan het onderzoeksproject halverwege opzegde.

De deelnemers waren gemiddeld 15,8 jaar (met een spreiding tussen de 5 en 31 jaar) als huisarts werkzaam.

De vier voor het gezamenlijk consult gemoriveerde orthopaedisch chirurgen die deelnamen aan het onderzoek, waren lid van de medische staf van het AZM. Ieder van hen was gekoppeld aan een vaste groep huisartsen.

De werkzaamheden passend binnen het gezamenlijk consultonderzoek werden verricht binnen het dienstverband bij de vakgroep Orthopaedie. De vakgroep Orthopaedie ontving hiervoor een honorarium conform de gedeclareerde uurvergoedingen. Dit gold eveneens voor de aan het onderzoek deelnemende huisartsen. 


\subsection{Het prospectief gerandomiseerd onderzoek: de patiënteninstroom}

\subsubsection{In- en uitsluitingscriterla}

Patiënten voor wie de huisartsen tijdens een consult van mening waren dat een gezamenlijk consult zinvol zou zijn, kwamen in principe in aanmerking voor het gezamenlijk consult. Het consult, waarin de huisarts de indicatie stelt voor het gezamenlijk consult, wordt verder steeds het instroomconsult genoemd.

De grenzen aan de deelname werden gesteld door de uitsluitingscriteria.

Patiënten met een leeftijd jonger dan 10 jaar en ouder dan 75 jaar werden uitgesloten van het onderzoek. Hoewel we verwachtten dat het gezamenlijk consult voor deze leeftijdscategorieën wel zinvol zouden kunnen zijn, werden zij uitgesloten, omdat een betrouwbare meting van de subjectief ervaren effecten voor het onderzoek niet goed mogelijk leek.

Patiënten bij wie de huisartsen van mening waren dat acute behandeling noodzakelijk was, werden eveneens uitgesloten ter voorkoming van mogelijk optredend 'doctor's delay'.

Bovendien werden patiënten uitgesloten wanneer de huisartsen meenden dat er een duidelijke verwijsindicatie aanwezig was, terwijl de verdere toestand en de omstandigheden van de patiënt geen aanleiding vormden tot specifiek overleg, met andere woorden; patiënten met een volgens de huisarts duidelijke verwijsindicatie zonder verdere problemen.

\subsubsection{Onderzoekspopulatie: aantallen patiënten}

Om relevante en statistisch valide uitkomsten te kunnen verkrijgen hebben we de hiervoor benodigde aantallen patiënten met de volgende uitgangspunten berekend:

- We verwachtten dat van de groep patiënten waarbij het gezamenlijk consult wordt gerealiseerd ongeveer $60 \%$ verwezen zou worden wanneer deze mogelijkheid niet zou bestaan.

- We wilden minimaal een reductie van $20 \%$ van dir verwijspercentage (60\%) kunnen aantonen.

- Gegeven een $\alpha$ fout van 0,05 en een $ß$ fout van 0,10 , en tweezijdige toetsing.

Met bovenstaande uitgangspunten is er per groep minimaal een aantal van 130 patiënten nodig. (4)

Bij een uitvalspercentage van ongeveer $25 \%$ zullen de groepen uit minimaal 175 patiënten moeten bestaan. Dit werd mogelijk geacht indien de intake-fase één jaar zou duren, bij een deelname van twaalf artsen.

\subsubsection{Randomisatiemethode, -procedure en informed consent}

Om de effecten van het gezamenlijk consult te kunnen vergelijken met die van consulten in de gebruikelijke zorg, is voor het effectiviteitsonderzoek gekozen voor een gerandomiseerde indeling van de door de huisartsen voor het gezamenlijk consult geschikt geachte patiënten. (1,2,4-6)

Een opzet waarbij huisartspraktijken at random zouden worden verdeeld stuitte op teveel praktische bezwaren, vanwege de te beperkte aantallen praktijken, die konden deelnemen. Bovendien geldt ook een principieel methodologisch bezwaar: 
we wilden nagaan wat het effect van het gezamenlijk consult was in aanvulling op het nascholingseffect, en niet inclusief dit effect.

De randomisatie binnen de aan het onderzoek deelnemende huisartspraktijken had als nadeel dat eventuele effectverschillen tussen interventie- en controlegroep mogelijk minder duidelijk vastgesteld kunnen worden. De nascholingseffecten die waren te verwachten als gevolg van het gezamenlijk consult, zouden de behandeling van de controlegroeppatiënten zodanig kunnen beïnvloeden, dat het verschil tussen de uitkomsten van beide groepen patiënten afneemt. De bewijsvoering van het effectiviteitsonderzoek zou er dientengevolge door kunnen worden bemoeilijkt. Echter, indien een effect zou worden gevonden, dan zou dit een extra overtuigend karakter hebben.

Patiënten die in aanmerking kwamen om deel te nemen aan het gezamenlijk consult werden at random verdeeld in twee groepen: de interventiegroep en de controlegroep. Patiënten voor de interventiegroep werden uitgenodigd voor het gezamenlijk consult, terwijl die van de controlegroep hiervoor niet mochten worden uitgenodigd.

In dit onderzoek was het noodzakelijk om te kiezen voor het zogenaamde 'Zelendesign' (7): eerst werd voor iedere voor het onderzoek in aanmerking komende patiënt een enveloppe getrokken, die (in random volgorde volgens Statistical Tables for the Design of Clinical Trials; David Machin \& MJ Campbell; chapter 13) de informatie bevatte over de groep waarin de patiënt zou vallen. Vervolgens werd de 'interventiegroep' uitgenodigd om deel te nemen aan het gezamenlijk consult en het daarbij behorende vervolgonderzoek.

Aan de controlegroep, die de gebruikelijke zorg zou krijgen, werd gevraagd of men mee wilde werken aan het vervolgonderzoek met betrekking tot de gepresenteerde klachten.

Deze opzet was noodzakelijk, omdat bij informatie over de randomisatieprocedure vóóraf, het onderzoek niet uitvoerbaar zou zijn: vermoed kon worden dat relatief veel patiënten zich dan primair of secundair zouden aanmelden voor het gezamenlijk consult, dan wel (onnodig) op verwijzing zouden aandringen.

Omdat de gebruikelijke zorg steeds werd geboden, terwijl à priori niet duidelijk was of het gezamenlijk consult een meerwaarde voor de patiënt zou hebben, werd, gezien het belang van het beantwoorden van de vraagstelling, deze opzet verantwoord geacht. $(8-11)$

De medisch-ethische commissie van het Academisch Ziekenhuis Maastricht ging met deze opzet accoord.

De randomisatie en de bijbehorende controle verliep concreet als volgt:

Patiënten, ingedeeld voor de interventiegroep, werden uitgenodigd een afspraak te maken voor een gezamenlijk consult. $\mathrm{Zij}$ ontvingen daarbij zowel mondeling als schriftelijk informatie over de werkwijze en het onderzoek.

Patiënten behorend tor de controlegroep werden eveneens mondeling en schriftelijk geïnformeerd.

Het correct volgen van de randomisatievolgorde was van groot belang voor het welslagen van het onderzoek. De huisartsen werden diverse malen met nadruk er op gewezen niet van de ontvangen enveloppevolgorde af te wijken. 
De enveloppen werden aangevuld, wanneer uit de registratie van de ontvangen enquêteformulieren bleek dat de voorraad dreigde op te raken.

Om na te gaan in hoeverre de huisartsen de randomisatievolgorde correct opvolgden, maakten we gebruik van de volgorde waarin we de ingevulde pariëntenenquêteformulieren ontvingen en vergeleken we deze met de geregistreerde randomisatievolgorde.

Om dezelfde reden werden vanaf de start de achtergrondgegevens van de patiënten van beide groepen regelmatig vergeleken.

Hiermee was het eveneens mogelijk een indruk te krijgen over de mate waarin de voorgeschreven randomisatievolgorde werd gevolgd.

De huisartsen werden diverse malen hierover geïnformeerd.

\subsection{Gezamenlijke consult- en controlespreekuren}

\subsubsection{Het gezamenlijk consultspreekuur}

Patiënten die in aanmerking kwamen voor het gezamenlijk consultspreekuur werden tijdens het instroomconsult gevraagd een vragenformulier in te vullen en op te sturen naar de projectleiding.

De huisartsen hadden voorafgaand aan het gezamenlijk consult eveneens een vragenformulier naar aanleiding van de tijdens het instroomconsult gepresenteerde klacht ingevuld. De inhoud van de verschillende vragenformulieren wordt beschreven in paragraaf 2.5.4.; meetinstrumenten.

Tijdens het gezamenlijk consult besprak de huisarts, al of niet in aanwezigheid van de patiënt, de klacht, het verrichte vooronderzoek, de vraagstelling en eventueel relevante bijkomende informatie.

Vervolgens nam de orthopaedisch chirurg de anamnese af en verrichtte het lichamelijk onderzoek. Desgewenst vulden de huisartsen de anamnese aan of onderzochten zij de patiënt eveneens. Vervolgens werd een evaluatie gemaakt, een eventuele differentiële diagnose opgesteld en in overleg met de patiënt een behandelingsplan opgesteld.

Wanneer behandeling door middel van injectie of punctie geïndiceerd werd geacht, kon dit direct door de huisarts of door de orthopaedisch chirurg worden uitgevoerd.

$\mathrm{Na}$ afloop van het consult werden de bevindingen van het lichamelijk onderzoek door de orthopaedisch chirurg op een onderzoeksformulier geregistreerd. Patiënt en huisarts vulden een vragenformulier over het gezamenlijk consult in.

De huisarts maakte bovendien een vervolglijst waarop alle verrichtingen en verwijzingen, gerelateerd aan de ingangsklacht gedurende één jaar tot aan het controlebezoek, geregistreerd werden.

\subsubsection{De organlsatie van de gezamenlljke consultspreekuren}

Aan de hand van een checklist werd in de beginperiode van 1 januari 1989 tot 1 april 1989 een aantal gezamenlijk consultspreekuren zonder registratie uitgevoerd om te wennen aan de werkwijze en de organisatie. 
Vooraf was gesteld dat de verantwoordelijkheid voor de patiënt tot aan een eventuele verwijzing primair bij de huisarts zou berusten.

Deze afspraak is gemaakt om te voorkomen dat verschillen in taakafbakening de samenwerking zouden belemmeren.

De spreekuren werden vanaf 1 april 1989 in principe éénmaal per twee tot drie weken gepland (uitgezonderd de vakantieperioden) op het afgesproken praktijkadres van de groep, waar als enige extra voorziening een lichtbak voor röntgenfoto's was geplaatst.

De assistente van de praktijk waar de spreekuren plaatsvonden verzocht zo nodig het secretariaat van de afdeling orthopaedie, om eerder gemaakte röntgenfoto's aan de orthopaedisch chirurg voor het gezamenlijk consult mee te geven.

\subsubsection{Controleconsult (eindconsult)}

Eén jaar na het instroomconsult werd bij alle patiënren van beide groepen een controleconsult (verder in dit verslag steeds 'eindconsult' genoemd) uitgevoerd. Elke praktijkassistente organiseerde de controlespreekuren in de eigen huisartspraktijk.

Alle patiënten werden bij dit eindconsult door een hen onbekende orthopaedisch chirurg onderzocht.

Voorafgaand aan het eindconsult ontvingen de patiënten vragenformulieren betreffende hun klacht en algemene toestand.

De huisarts en de orthopaedisch chirurg vulden na het eindconsult een onderzoeks- en vragenformulier in.

Bovendien controleerde de huisarts het vervolgformulier, alvorens het in te leveren bij de projectleiding.

\subsubsection{Meetinstrumenten}

Bij de instroom-, de gezamenlijke- en de eindconsulten werden enquêteformulieren ingevuld, waarin een aantal meetinstrumenten zijn opgenomen.

Hiermee werden gegevens verkregen over de klachten, de pariëntvariabelen, de motieven en ervaringen van huisartsen en orthopaedisch chirurgen.

Als meetinstrumenten om de subjectief ervaren lichamelijke toestand vast te stellen zijn een korte VOEG-lijst van 13 vragen (12), een aangepaste versie van de S.I.P.-lijst (13-19) en een vragenlijst betreffende de ervaren gezondheidstoestand conform de C.B.S.-enquêtelijst opgenomen. $(3,20)$

Om de patiënten niet onnodig te belasten met vragen die niet relevant zijn voor dit onderzoek zijn van de twaalf categorieën van de S.I.P.-lijst een vijftal volledig weggelaten, namelijk de categorieën: sociale interacties, alertheid/intellectueel functioneren, communicatie, werk en eten. Deze beperkingen doen geen afbreuk aan de validiteit. (21-23)

Voor de vaststelling van de lichamelijke toestand werden onderzoeklijsten ingevuld.

Om de ingangsklachten en diagnoses te registreren is gebruik gemaakt van de ICPC-coderingslijst (zie bijlage 13). (24-26) 
Met vervolglijsten werden de bezoeken, verrichtingen en verwijzingen (proces- of zorgvariabelen) die tijdens het jaar na instroom plaatsvonden, geregistreerd.

De onderscheiden formulieren werden op de volgende momenten verstrekt en ingevuld:

De patiënten van beide groepen ontvingen tijdens het instroomconsult, direct na randomisatie en consent, een informatieve brief en een vragenlijst met het verzoek deze binnen twee dagen in te vullen en vervolgens op te sturen naar de projectleiding (formulier bijlage $1 \mathrm{~A}+\mathrm{B}$ ).

De huisartsen vulden na het instroomconsult eveneens een vragen- en onderzoeksformulier in (formulier bijlage $2 \mathrm{~A}+\mathrm{B}$ ).

Bovendien werd een vervolglijst bij het kaartsysteem van de huisarts gevoegd (bijlage 3).

$\mathrm{Na}$ afloop van het gezamenlijk consult (interventiegroep) werden door patiënt, huisarts en specialist een vragenformulier en een onderzoeksformulier ingevuld (bijlagen 4,5,6).

Eén jaar na het instroomconsult ontvingen de patiënten een vragenformulier (bijlage $7 \mathrm{~A}+\mathrm{B}$ ), dat zij voorafgaand aan het eindconsult dienden in te vullen en op te sturen.

De huisarts vulde na afloop van het eindconsult een vragenformulier (bijlage $8 \mathrm{~A}+\mathrm{B}$ ) in, terwijl de specialist uitsluitend een onderzoeksformulier (bijlage 9) invulde, wanneer er naar zijn mening nog klachten aanwezig waren met betrekking tot de ingangsklacht.

Bovendien werden huisartsen en orthopaeden aan het eind van het project geënquêteerd over hun ervaringen (bijlagen 10 en 11).

\subsubsection{Statistische analyse methoden}

In de statistische analyse werden in de eerste plaats bivariate analyses verricht door middel van frequentieverdelingen en kruistabellen.

Statistische toetsing werd verricht door middel van de Fisher Exact Test, de Chikwadraattoets voor onafhankelijke proporties, de Wilcoxon signed-rank test en door middel van de T-toets voor onafhankelijke gemiddelden. Steeds werd tweezijdig getoetst met een significantiedrempel van 0.05 .

Ten einde na te gaan in hoeverre bij de vOEG-enquêtes de totaalscores van de groepen al dan niet tot stand zijn gekomen door overeenkomstige scoreveranderingen van de individuele patiënten is gebruik gemaakt van de Wilcoxon toets. Door middel van 'backward stepwise multiple logistische analyse' (BMDP-LR) werden de invloeden van diverse onafhankelijke variabelen op relevante uitkomstvariabelen in onderlinge samenhang bestudeerd.

De daarbij gehanteerde onafhankelijke- en afhankelijke variabelen zijn weergegeven in bijlagen 17-31.

In de resultaten van deze analyse worden de bijdragen van de afzonderlijke onafhankelijke variabelen weergegeven door middel van odds ratio's met hun $95 \%$ betrouwbaarheidsinterval.

Gepresenteerd worden per afhankelijke variabele het 'full model' (waarmee de backward analyse begon) en het 'reduced model' dat alleen nog significant 
bijdragende onafhankelijke variabelen bevat. Deze resultaten worden vermeld in de bijlagen $17 \mathrm{t} / \mathrm{m} \mathrm{31}$, en in onderlinge samenhang, veelal per onafhankelijke variabele, besproken.

Bovendien werd door middel van multipele lineaire regressie analyse nagegaan welke verrichtingen ('röntgen', 'medicatie', 'injecties' en 'fysiotherapie') van huisarts en orthopaedisch chirurg tezamen, een sterke en significante samenhang vertoonden met de onafhankelijke variabelen. De resultaten hiervan zijn vermeld in de bijlage 32 en worden per verrichting en waar relevant, per onafhankelijke variabele besproken.

\section{Literatuur}

1 Knottnerus JA, Ver HCW de. Effectiviteitsonderzoek in de huisartspraktijk. Huisarts Wer 1987;30:49-53.

2 Feinstein AR. Clinical epidemiology: the architecrure of clinical research. Philladelphia: Sauders, 1985.

3 Swinkels H. Huisarts en pariënt in cijfers. Huisarts Wet 1990;33(13):504-10.

4 Knottnerus JA, Volovics A. Medische statistiek en onderzoek in de huisartsgeneeskunde. NHG-publikaties 1990;nr 4.

5 Knottnerus JA, Vet HCW de. Effectiviteitsonderzoek in de huisartspraktijk. Huisarts Wet 1987:30:72-5.

6 Knortnerus JA, Ver HCW de. Effecriviteirsonderzoek in de huisartspraktijk. Huisarts Wet 1987:30:116-9.

7 Zelen M. A new design for randomized clinical trials. N Engl J Med 300(22):1242-5, 31 may 1979

8 Lamberts, $\mathrm{H}$. Interventie onderzoek en informed consent: een dilemma voor huisarts en patiënt? Huisarts Wet 1987;30:183-7.

9 Uden MMAT van, Dam FSAM van. Informed consent bij klinisch kankeronderzoek: psychologische aspecten. Ned Tijdschr Geneeskd 1986;130(46):2078-82.

10 Stull WM, Lo B, Charles G. Do patients want to participate in medical decision making? JAMA 1984;252:2990-4.

11 Beaufort I de. Ethiek en medische experimenten met mensen. Assen: van Gorcum 1985.

12 Joosten J, Drop MJ. De betrouwbaarheid en vergelijkbaarheid van drie versies van de VOEG. Gezondheid en Samenleving 1987;10:251-65.

13 Bock GH de, Rijneveld SA, Haan M de. Geneeskunde en kwaliteit van leven. MC $1990 ; 22: 701-4$.

14 Bergner M, Bobbitt RA, Cartner WB, Gibson BS. The Sickness Impact Profile: Development and Final Revisions of a Health Starus Measure. Med Care 1981;19:787-805.

15 Lurtik A, Jacobs HM, Witte LP de. De Sickness Impact Profile. Nederlandse versie. Utrecht: Rijksuniversiteit, Vakgroep Huisartsgeneeskunde 1985.

16 Jacobs HM, Lutrik A, Touw-Otren FWMM, Melker RA van. De 'Sickness Impact Profile'; resultaten van een validerings van de Nederlandse versie. Ned Tijdschr Geneeskd $1990 ; 134 ; 40: 1950-4$.

17 Gilson BS, Gilson JS, Berquer et al. The Sickness Impact Profile. Development of an outcome measure of health care. AMJ. Public Health 1975;65:1304-10.

18 Melker RA de, Touw-Otten FWMM, Jacobs HM, Lutrik A. De waarde van de 'Sickness Impact Profile' als uitkomstmeting. Ned Tijdschr Geneeskd 1990;134(19):946-8. 
19 Witte L de, Jacobs HM. Horst F van der, Luttik A, Joosten J, Philipsen H. De waarde van de Sickness Impact Profile als maat voor het functioneren van patiënten. Gezondheid en Samenleving 1987;8:120-7.

20 Bensing JM, Foers M, Velden J van der, Zee J van der. De Nationale Studie van ziekten en verrichtingen in de huisartsprakrijk. Huisarts Wet 1991;34(2):51-61.

21 Bruin AF de, Witte LP de, Stevens F, Diederiks JPM. Sickness Impact Profile: the state of the art of a generic functional status measure. Soc Science Med Vol 1992;35(8): 1003-14.

22 Essink-Bot ML, Agt HME van, Bonsel GJ. NHP of SIP: een vergelijkend onderzoek onder chronisch zieken. TSG 1992;70:152-9.

23 Bruin AF de, Witte LP de, Stevens FCJ, Diederiks JPM. De bruikbaarheid van de Sickness Impact Profile als generieke maat voor functionele toestand. TSG 1992;70: $160-70$.

24 Lamberts $\mathrm{H}$, Wood M, c.s. International Classification of Primary care. Oxford: Oxford University Press 1987.

25 Lamberts H, Wood M, Hofmans-Okkes I, Marinus A. Communiceren en classificeren. Huisarts Wet 1991;34(7):346-52.

26 Meyer JS, Brouwer H, Lamberts HJ. De I.C.P.C. als diagnostische classificatie. Huisarts Wet 1987;30:13-9,44-8. 



\section{Het effectiviteitsonderzoek}

\section{TEN GELEIDE}

Van het prospectief gerandomiseerd effectiviteitsonderzoek, verricht in de twaalf huisartspraktijken, verliep de instroom van 339 patiënten vanaf 1 april 1989 tot 1 januari 1991.

De eindconsulten werden verricht tot 1 januari 1992.

Tijdens het totale onderzoek van 1 april 1989 tot 1 januari 1992, werden van patiënten, huisartsen en orthopaeden gegevens verzameld.

De onderzoeksvariabelen worden in schema 3.1 onderverdeeld in patiënt- en klacht-, proces- of zorgvariabelen en in voorspellende en effectvariabelen (eveneens schema 3.1.).

De paragrafen waarin de variabelen achtereenvolgens in de volgorde van dir schema worden beschreven, beginnen, uitgezonderd de ecrste paragraaf, mer een inleiding, gevolgd door een bespreking en analyse van de resultaten, waarna besloten wordt met discussie en conclusies. Onder het hoofd 'resultaten' worden doorgaans eerst de instroomgegevens beschreven waarna, indien aanwezig, bevindingen volgen waarmee effecten van de zorgverlening kunnen worden vastgesteld.

In deze paragrafen worden de patiënt- en klachtvariabelen voor interventie- en controlegroep een aantal malen beschreven, gerelateerd aan de vraag of de patiënten binnen het tijdsverloop van één jaar al of niet zijn verwezen.

Deze analyses zijn verricht omdat verwijzing als belangrijke effectvariabele wordt beschouwd. Ter voorkoming van een overvloed aan tabellen van genoemde analyses worden deze vrijwel uitsluitend weergegeven, wanneer belangrijke verschillen werden gevonden tussen interventie- en controlegroep.

In de tabellen worden de procentuele verdelingen van de totale groepen steeds in de verticale richting weergegeven. De percentages ingevuld in de kolom 'verwezen patiënten' laten steeds horizontaal in de kolommen zien welk deel van de groep van de betreffende categorie is verwezen.

De resultaten van de analyses door middel van multipele logistische regressie worden in de bijlagen met full en reduced model weergegeven en in de tekst in hoofdzaak besproken, wanneer significante effecten zijn vastgesteld. De resultaten van afzonderlijke regressie analyses voor de interventie- en controlegroep apart, zijn niet in de bijlagen opgenomen maar uitsluitend voor zover relevant in de tekst verwerkt. 


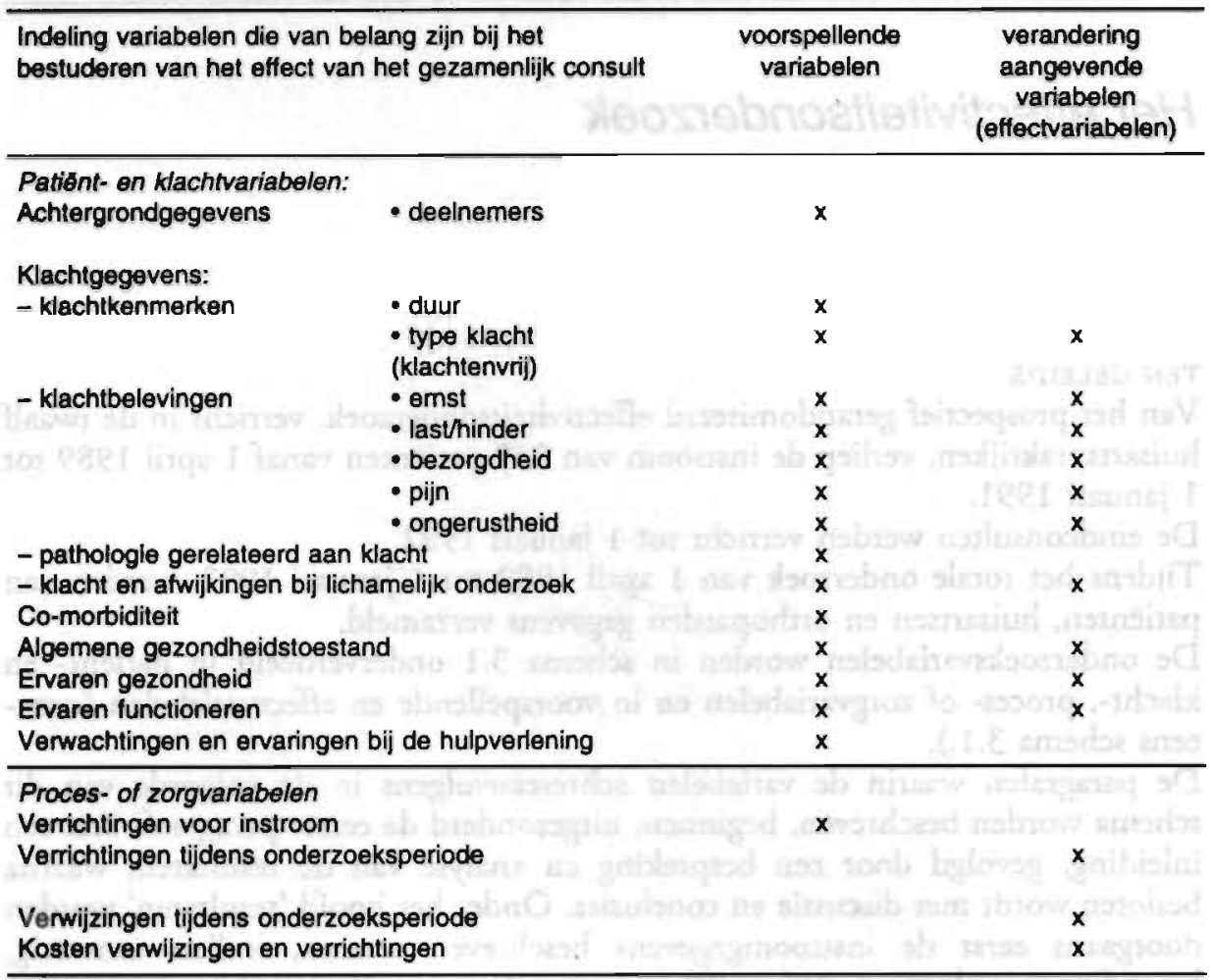

\subsection{Patiënt- en klachtvariabelen}

\subsubsection{Achtergrondgegevens, deelname, uitval en verwijsaantallen}

\section{ACHTERGRONDGEGEVENS}

Waar voor de effectstudie gekozen is voor een gerandomiseerde verdeling van de patiënten in een tweetal vergelijkbare groepen, is het van belang dat beide groepen tijdens het instroommoment ook inderdaad overeenkomen.

In paragraaf 2.4.3 (randomisatie) is reeds beschreven dar de achtergrondgegevens werden gebruikt om na te gaan in hoeverre de randomisatie correct verliep. Als achtergrondgegevens zijn geslacht, verzekeringsvorm, leeftijd, burgerlijke staat en opleiding geregistreerd (zie tabel 3.1.1.I, II, III en IV).

Uit deze gegevens is op te maken dat er geen relevante verschillen zijn tussen beide groepen.

Ook wat betreft de overige patiëntvariabelen zijn eveneens vrijwel overeenkomstige patronen in beide groepen vast te stellen. 
Bij de verdeling naar verzekeringsvorm (zie paragraaf 2.2. en tabel 3.1.1.I) blijkt dat in beide onderzoeksgroepen het aantal ziekenfondsverzekerden vergeleken met de algemene patiëntenpopulatie enigszins is oververtegenwoordigd. Dit komt overeen met de bevindingen van het NIVEL-onderzoek 'Determinanten van verwijzen door de huisarts naar de tweede lijn' waar een groter aantal verwijzingen voor ziekenfondsverzekerden werd vastgesteld, (1) en uit eerdere onderzoeken van Boots en Van Zutphen (2) en Van der Zee (3).

Tabel 3.1.1.I Verdeling naar geslacht en verzekeringsvorm bij instroom.

\begin{tabular}{llccccccccccc}
\hline & Interventiegroep & $n=144$ & \multicolumn{10}{c}{ Controlegroep n=128 } \\
\hline & & $n$ & $\%$ & & $n$ & $\%$ & & $n$ & $\%$ & & $n$ & $\%$ \\
\hline geslacht & man & 70 & 49 & vrouw & 74 & 51 & man & 64 & 50 & vrouw & 64 & 50 \\
\hline $\begin{array}{l}\text { verzeke- } \\
\text { ringsvorm }\end{array}$ & $\begin{array}{l}\text { zieken- } \\
\text { fonds }\end{array}$ & 117 & 81 & $\begin{array}{l}\text { parti- } \\
\text { culier }\end{array}$ & 27 & 19 & $\begin{array}{l}\text { zieken- } \\
\text { fonds }\end{array}$ & 103 & 80 & $\begin{array}{l}\text { parti- } \\
\text { culier }\end{array}$ & 25 & 20 \\
\hline
\end{tabular}

Uit bijlage 12 en tabel 3.1.1.II valt op te maken dat in de onderzoekspopulatie de leeftijdscategorieën 30-39 jaar en 40-49 jaar enigszins zijn oververtegenwoordigd. Doorgaans wordt in de hogere leeftijdscategorieën meer verwezen, echter in dit onderzoek zijn de patiënten ouder dan 75 jaar uitgesloten van deelname.

Tabel 3.1.1.II Verdeling naar leeftijd bij instroom.

\begin{tabular}{|c|c|c|c|c|c|c|c|c|}
\hline \multirow[b]{3}{*}{ Leeftijd } & \multicolumn{4}{|c|}{ Interventiegroep $n=144$} & \multicolumn{4}{|c|}{ Controlegroep $n=128$} \\
\hline & \multicolumn{2}{|c|}{ Man } & \multicolumn{2}{|c|}{ Vrouw } & \multicolumn{2}{|c|}{ Man } & \multicolumn{2}{|c|}{ Vrouw } \\
\hline & $n=70$ & $\%$ & $n=74$ & $\%$ & $n=64$ & $\%$ & $n=64$ & $\%$ \\
\hline 10-19 jaar & 11 & 16 & 7 & 10 & 8 & 12 & 8 & 12 \\
\hline 20-29 jaar & 11 & 16 & 9 & 12 & 14 & 22 & 13 & 20 \\
\hline $30-39$ jaar & 19 & 27 & 12 & 16 & 12 & 19 & 12 & 19 \\
\hline 40-49 jaar & 12 & 17 & 23 & 31 & 11 & 17 & 17 & 27 \\
\hline 50-59 jaar & 9 & 13 & 8 & 11 & 7 & 11 & 9 & 14 \\
\hline $60-69$ jaar & 5 & 7 & 12 & 16 & 10 & 16 & 4 & 6 \\
\hline 70-76 jaar & 3 & 4 & 3 & 4 & 2 & 3 & 1 & 2 \\
\hline totaal & 70 & 100 & 74 & 100 & 64 & 100 & 64 & 100 \\
\hline
\end{tabular}


Tabel 3.1.1.III Verdeling naar burgerlijke staat bij instroom.

\begin{tabular}{lcc}
\hline Burgertijke staat & $\begin{array}{c}\text { Interventiegroep } n=144 \\
\%\end{array}$ & $\begin{array}{c}\text { Controlegroep } n=128 \\
\%\end{array}$ \\
\hline gehuwd & 58,9 & 60,0 \\
samenwonend & 5,6 & 3,9 \\
nooit gehuwd of samenwonend geweest & 17,4 & 21,9 \\
gescheiden of niet meer samenwonend & 5,6 & 6,3 \\
weduwe/weduwnaar & 8,3 & 1,6 \\
anders & 4,2 & 6,3 \\
lotaal & 100 & 100 \\
\hline
\end{tabular}

Tabel 3.1.1.IV Verdeling naar hoogst genoten opleiding bij instroom.

\begin{tabular}{lcc}
\hline Opleiding & $\begin{array}{c}\text { Interventiegroep } n=144 \\
\%\end{array}$ & $\begin{array}{c}\text { Controlegroep } n=128 \\
\%\end{array}$ \\
\hline basisschoollo & 27,1 & 21,1 \\
Ib & 21,6 & 18,0 \\
mulo/mavo & 10,4 & 21,9 \\
mbo & 15,3 & 12,4 \\
hbs/havo/nwo & 4,9 & 12,5 \\
hbo & 9,7 & 5,5 \\
wetenschappelijk onderwijs & 2,1 & 0,0 \\
een andere opleiding & 4,8 & 6,3 \\
nlet ingevuld & 4,1 & 2,3 \\
tolaal & 100 & 100 \\
\hline
\end{tabular}

DEELNAME EN UitVAL.

Patiënten reageerden desgevraagd, met uitzondering van én patiënt, positief op het voorstel deel te nemen aan het onderzoek.

Bij de instroom was er een directe uitval van 8 patiënten uit de interventiegroep en 11 patiënten uit de controlegroep ontstaan, door het niet invullen van de enquêteformulieren (=geen deelname na randomisatie).

De totale uitval bedroeg blijkens tabel 3.1.1.V voor de interventie- en de controlegroep respectievelijk $17 \%$ en $23 \%$ en verschilde per huisarts. De verschillende redenen van uitval kwamen voor beide groepen sterk overeen (tabel 3.1.1.VI). 
Tabel 3.1.1.V Aantallen patiënten door de huisartsen voor het onderzoek uitgenodigd en de uitval.

\begin{tabular}{crrrcrc}
\hline Artsnummer & $\begin{array}{c}\text { Interventie- } \\
\text { groep }\end{array}$ & $\begin{array}{c}\text { Controle- } \\
\text { groep }\end{array}$ & $\begin{array}{c}\text { Totaal aantal } \\
\text { patiënten bij } \\
\text { instroom }\end{array}$ & $\begin{array}{c}\text { Uitval } \\
\text { interventie- } \\
\text { groep }\end{array}$ & $\begin{array}{c}\text { Uitval } \\
\text { controle- } \\
\text { groep }\end{array}$ & $\begin{array}{c}\text { Totaal aantal } \\
\text { patienten } \\
\text { instroom } \\
\text { minus uitval }\end{array}$ \\
\hline 1. & 9 & 7 & 16 & 5 & 1 & 10 \\
2. & 15 & 13 & 28 & 1 & 2 & 25 \\
3. & 13 & 13 & 26 & 0 & 4 & 22 \\
4. & 3 & 1 & 4 & 3 & 1 & 0 \\
5. & 30 & 30 & 60 & 7 & 7 & 46 \\
6. & 7 & 8 & 15 & 1 & 2 & 12 \\
7. & 18 & 17 & 35 & 3 & 3 & 29 \\
8. & 26 & 27 & 53 & 2 & 10 & 41 \\
9. & 18 & 17 & 35 & 3 & 3 & 29 \\
10. & 6 & 7 & 13 & 2 & 2 & 9 \\
11. & 12 & 11 & 23 & 0 & 2 & 21 \\
12. & 16 & 15 & 31 & 2 & 1 & 28 \\
totaal & 173 & 166 & 339 & 29 & 38 & 272 \\
procentueel & $51 \%$ & $49 \%$ & $100 \%$ & $17 \%$ & $23 \%$ & $80 \%$ \\
\hline
\end{tabular}

Huisarts beëindigde deelname aan project

Tabel 3.1.1.VI Redenen uitval gezamenlijk consult.

\begin{tabular}{lrc}
\hline & Interventiegroep & Controlegroep \\
\hline Verhuisd, veranderd van huisarts, geen & 7 & 13 \\
mogelijkheid instroom/eindconsult bij te wonen & 11 & 16 \\
patiënt wil nlet meer meewerken & 4 & 2 \\
uitval wegens leeftijd <10 en $>75$ jaar & 3 & 1 \\
huisarts beï indigde deelname onderzoek & & 3 \\
wegens gezondheidsredenen niet kunnen & 1 & 3 \\
deelnemen & 3 & 38 \\
anders & 29 & \\
tolaal & & \\
\hline
\end{tabular}

- 1x patiēnt geeft andere klacht aan dan huisarts/orthopaed

- $1 x$ patiēnt analfabeet

$-1 x$ patiênt engelstalig

- 1x patiēnt vinott hel invullen een te grote psychische belasting

$-1 x$ echtscheiding

$-1 x$ volgens huisarts formulier niet ontvangen

In beide groepen overleed én patiënt ten gevolge van een maligniteit. Klachten veroorzaakt door metastasen waren bij beide patiënten de aanleiding van het gezamenlijk consult. De uitval in de controlegroep was iets groter dan die van de interventiegroep (23 versus $17 \%$ ).

De interventie- en controlegroep bevatten na uitval respectievelijk 144 en 128 patiënten. Van deze aantallen zal in dit verslag worden uitgegaan. 
De oorzaak van de iets grotere uitval in de controlegroep is niet bekend. Het is echter mogelijk dat patiënten van de controlegroep minder gemotiveerd waren om deel te (blijven) nemen.

Wat betreft de redenen voor patiëntenuitval zien we tussen beide groepen geen belangrijke verschillen.

\section{VERVIJSPERCENTAGES}

In de interventie- en controlegroep van respectievelijk 144 en 128 patiënten, bedroegen de verwijspercentages respectievelijk $35 \%$ en $68 \%$, hetgeen een significant verschil betekent $(\mathrm{p}=<.01$, zie tabel 3.1.1.VII).

Deze verwijspercentages zijn zoals beschreven onder 'Ten Geleide' (hoofdstuk 3) steeds gerelateerd aan de onderscheiden variabelen.

Tabel 3.1.1.VII Verwijzingen tijdens het jaar na het instroomconsult.

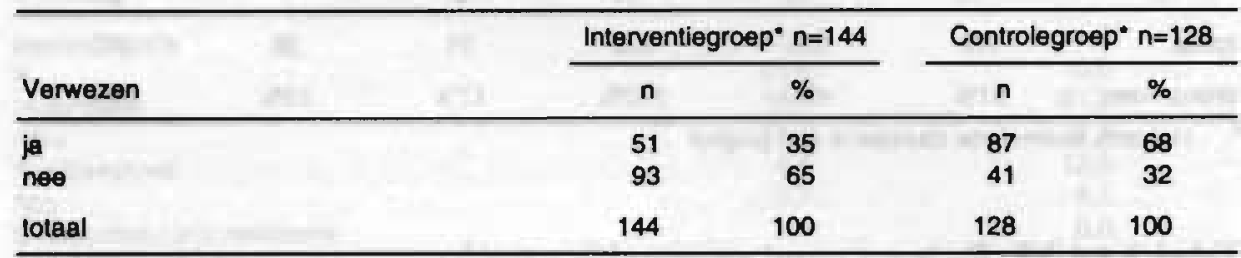

- Chi-kwadraattoets $p=<.01$

\subsubsection{Klachtgegevens}

\section{INLEIDING}

De klachtgegevens, onderverdeeld in de variabelen 'klachtkenmerken', 'klachtbelevingen', 'aanwezigheid van pathologie in relatie tot de klacht' en 'klacht en afwijkingen: vastgesteld door lichamelijk onderzoek', informeren over de 'klachtendoelgroep', welke door huisartsen voor het gezamenlijk consult wordt aangeboden.

Deze gegevens worden mede gebruikt ter controle van de randomisatie en kunnen als mogelijk prognostische factor worden gerelateerd aan de effectvariabelen.

\subsubsection{Klachtkenmerken}

\section{INLEIDING}

De aan het instroomconsult voorafgaande duur van de klacht en behandeling, alsmede de schatting van de huisartsen in hoeverre de aangeboden klachten al dan niet vaak in de huisartspraktijk voorkomen en de gepresenteerde klachten en diagnoses, worden klachtkenmerken genoemd.

De lengte van de klachtperiode (klachtduur) en de lengte van de behandelingsperiode (behandelingsduur) spelen volgens Bergsma een rol in het beslissingspro- 
ces van de huisarts, als gevolg waarvan een patiënt in aanmerking komt voor een verwijzing. $\mathrm{Zij}$ zijn bovendien warschijnlijk van invloed op het verdere verloop, de verrichtingen en de verwijzingen. (4)

Voor het gezamenlijk consult verwachtten we in dit verband hetzelfde. Om deze reden zijn tijdens de instroomconsulten zowel aan de patiënten als aan de huisartsen vragen gesteld over de klachtduur. Dit laatste is gedaan, omdat uit onderzoek bekend is dat de meningen van patiënten en huisartsen met betrekking tot de contactreden belangrijk kunnen verschillen. $(4,5)$

Zowel de klachtduur als behandelingsduur werden geregistreerd met een indeling in 4 categorieën, $\mathrm{nl}$. < 1 maand; 1-5 maanden; 6-11 maanden en $\geq 1$ jaar.

Eveneens om het klachtenaanbod en daarmee de doelgroep voor het gezamenlijk consult beter te kunnen typeren, zijn naast bovenstaande klachtkenmerken tijdens de instroomconsulten aan de huisartsen bij iedere nieuwe patiënt vragen gesteld over de geschatte prevalentie van de betreffende klachr.

De vragen naar het voorkomen van de klacht in de huisartspraktijk konden worden beantwoord met de categorieën 'zelden', 'regelmatig' of 'vaak'.

Omdat deze vragen indrukken van de huisartsen betreffen, geven zij slechts globale informatie.

De klachten/diagnoses zijn met behulp van de voor de huisartsgeneeskunde ontwikkelde en goed hanteerbare International Classification of Primary Care (I.C.P.C.-)codering (zie bijlage 13) geregistreerd. (6-11)

$\mathrm{Bij}$ de rubricering van de ingangsklachten in het voor ons onderzoek relevante hoofdstuk L (bewegingsapparaat), is uitgegaan van de klachten zoals deze spontaan door de patiënten zijn gebracht.

\section{RESULTATEN}

De tabellen 3.1.2.1.I en II laten zien dat qua klacht- en behandelingsduur geen significante verschillen aanwezig zijn tussen interventie- en controlegroep.

De klachten bestonden bij meer dan de helft van de patiënten langer dan een half jaar.

Kortdurende klachten kwamen zoals verwacht, mede ten gevolge van de in- en uitsluitingscriteria, weinig $( \pm 10 \%)$ voor.

Huisartsen schatten voor beide groepen patiënten zowel de duur van de klacht als die van de behandeling significant korter in dan de patiënten zelf deden. 
Tabel 3.1.2.1.I Klachtduur volgens patiënt en huisarts per groep bij het instroomconsult.

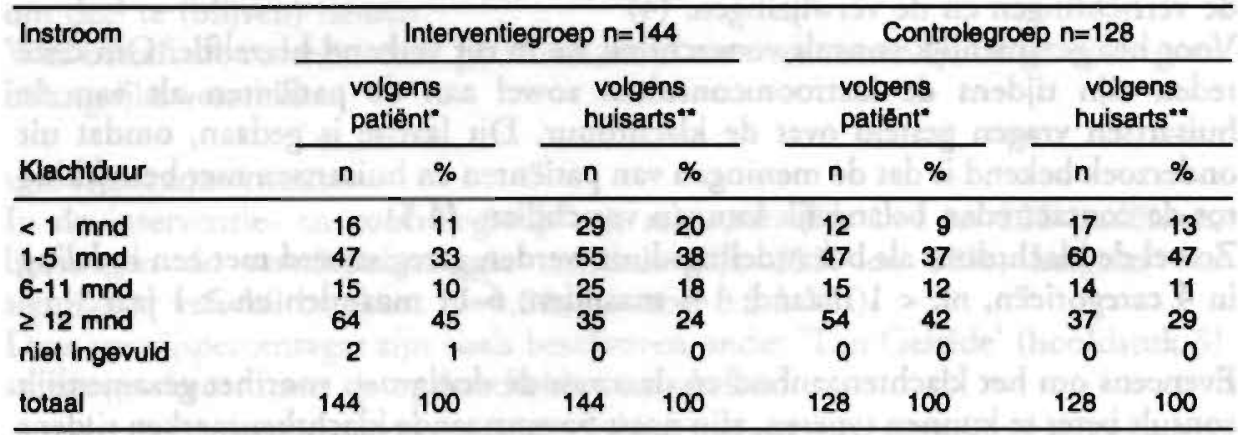

- Chi-kwadraattoets $p=0.87$

** Chi-kwadraattoets $p=0.13$

(getoetst met item 'niet ingevuld' als missing).

Wilcoxon signed-rank test patiënt-huisarts Interventiegroep $p=<.01$

Wilcoxon signed-rank test patiënt-huisarts Controlegroep $p=<.01$

Tabel 3.1.2.1.II Behandelingsduur volgens patiënt en huisarts per groep bij het instroomconsult.

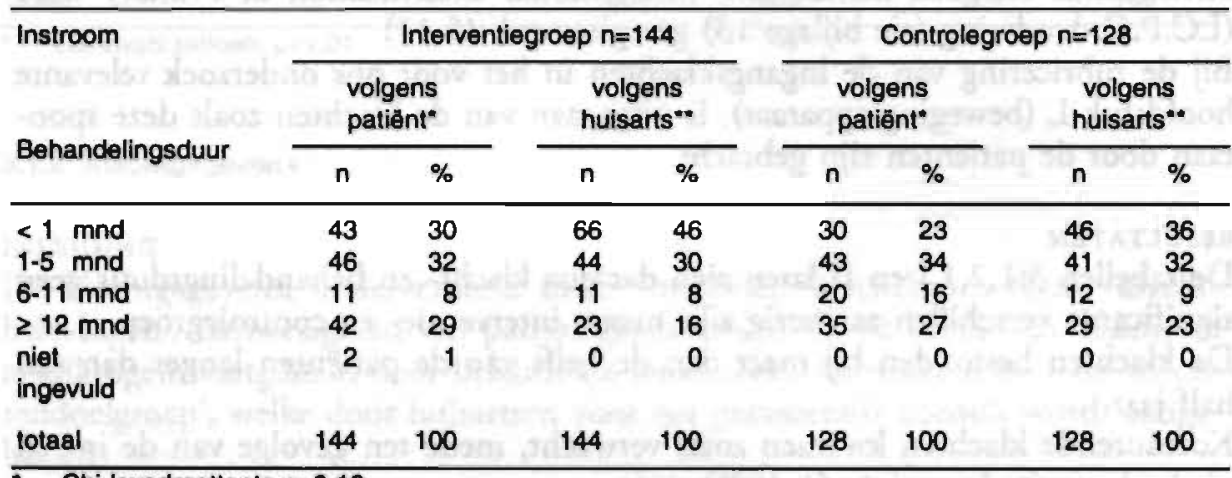

Chi-kwadraattoets $p=0.18$

*- Chi-kwadraattoets $p=0.32$

(getoetst met item 'niet ingevuld' als missing).

Wilcoxon signed-rank test patiēnt-huisarts Interventiegroep $p=<.01$

Wilcoxon signed-rank test patiënt-huisarts Controlegroep $p=<.01$

Uit de multivariate analyses blijkt dat patiënten met langer bestaande klachten een significant kleinere kans hadden om klachtenvrij te worden (bijlage 17), en een grotere kans om röntgenonderzoek te ondergaan (zie bijlage 32). Bij de patiënten met langdurige klachten was er in de controlegroep een grotere kans op door huisarts en orthopaed tezamen aangevraagd röntgenonderzoek, in de interventiegroep was dit het geval voor röntgenonderzoek dat door de huisarts was aangevraagd (respectievelijk $\mathrm{p}=0.04, \mathrm{O} . \mathrm{R} .0 .35,95 \% \mathrm{CI}=1.36-11.9$ ). 
Tabel 3.1.2.1.III De door de huisartsen geschatte frequentie waarmee de bij de instroomconsulten aangeboden klachten voorkomen.

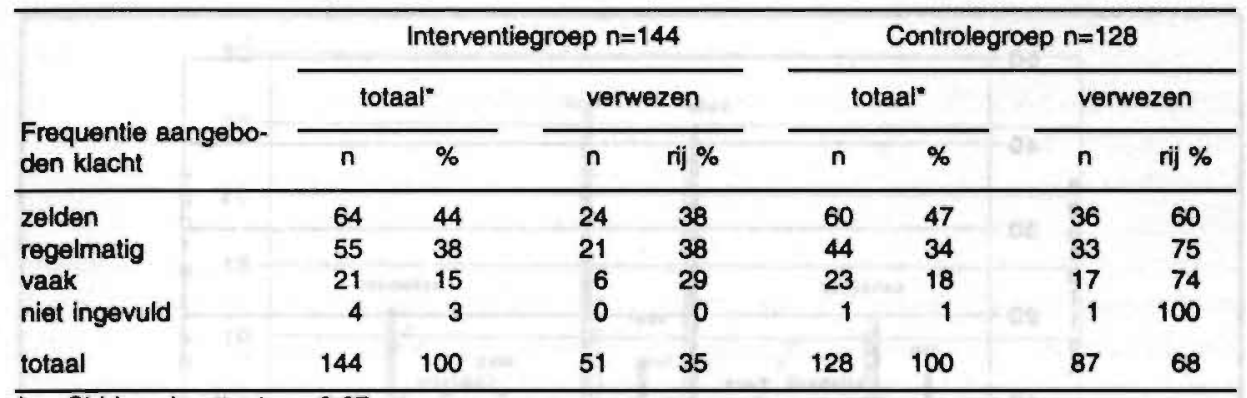

Chi-kwadraattoots $p=0.67$

(getoetst met item 'niet ingevuld' als missing).

Uit tabel 3.1.2.1.III blijkt dat de klachten aangeboden voor het gezamenlijk consult, volgens de huisartsen voor meer dan de helft (interventiegroep 53\%, controlegroep 52\%) onder de categorieën 'regelmatig' en 'vaak' vielen.

Gerelateerd aan de verwijzingen zijn er verschillen. In de controlegroep scoorden patiënten met de categorieën 'regelmatig' en 'vaak' in verhouding tor het 'overall' verwijscijfer (68\%) van de groep iets hoger. In de interventiegroep zien we het tegenovergestelde. Daar werden patiënten met 'vaak' voorkomende klachten minder vaak dan gemiddeld ( $29 \%$ regen $35 \%$ ) verwezen. Beide verschillen zijn echter niet significant.

In figuur 3.1.2.1.IV zien we de bij de instroomconsulten gecodeerde klachten en diagnoses.

Bij vergelijking van de klachten en diagnoses van beide groepen, valt op dat het aanbod in beide groepen sterk overeenkwam.

De figuren 3.1.2.1.V en VI laten de aangeboden klachten/diagnoses zien in relatie tot het al dan niet verwezen zijn.

Diagnoses welke in redelijk hoge aantallen (in beide groepen $>5 \mathrm{x}$ voorkomend) werden aangeboden, betreffen de ICPC-codes 3 (rug); 8 (schouder); 10 (elleboog); 12 (pols); 13 (heup); 15 (knie) en 17 (voet-teen). 
Figuur 3.1.2.1.IV Klachten/diagnoses volgens ICPC-codering bij de instroomconsulten voor Interventie- en Controlegroep.

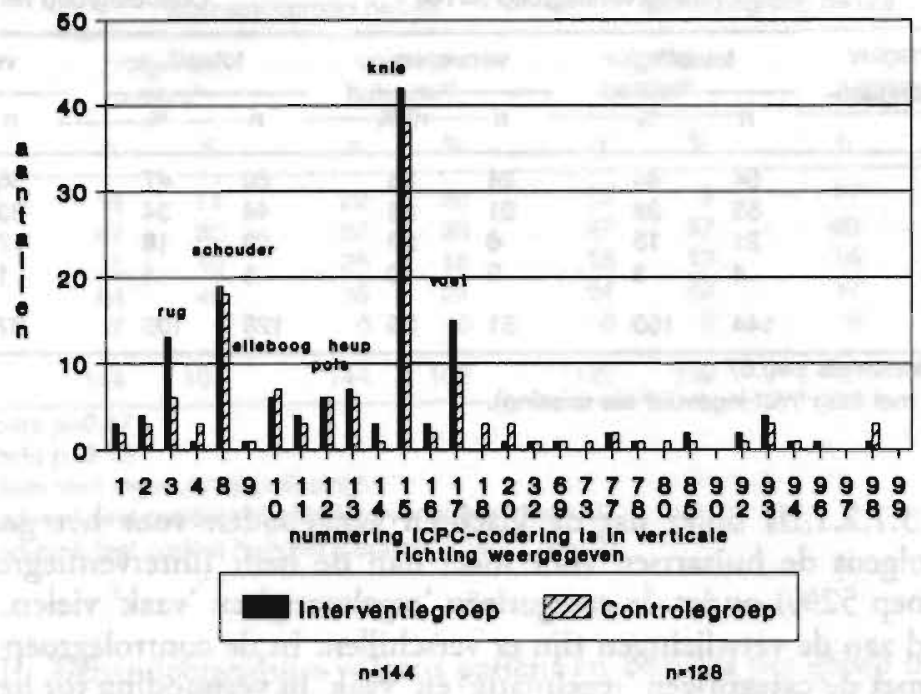

Figuur 3.1.2.1.V Klachten en diagnoses bij instroom van de Interventiegroep, gerelateerd aan verwijzingen.

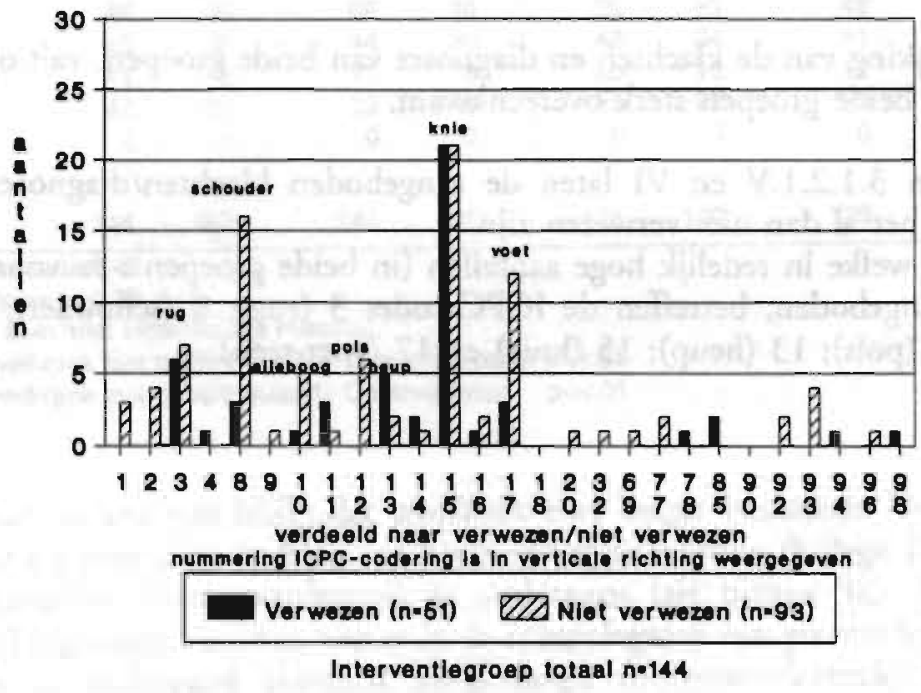


Figuur 3.1.2.1.VI Klachten en diagnoses bij instroom van de Controlegroep, gerelateerd aan verwijzingen.

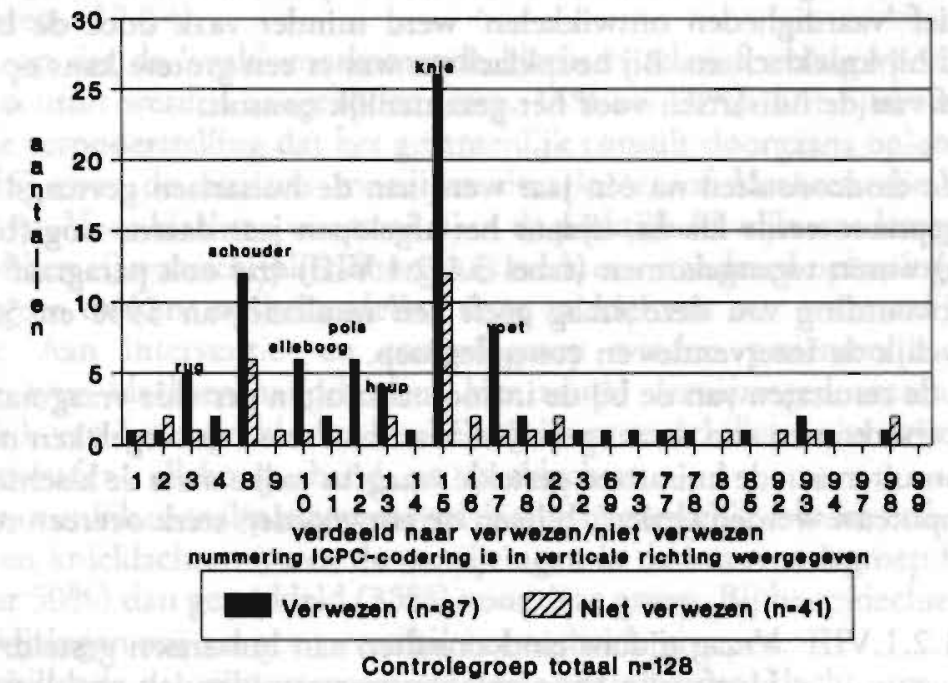

Tabel 3.1.2.1.VII

Verwijzingen, gerelateerd aan klachten/diagnoses.

\begin{tabular}{|c|c|c|c|c|c|c|c|c|}
\hline \multirow{3}{*}{$\begin{array}{l}\text { Klacht/diagnoses } \\
\text { ICPC-codering }\end{array}$} & \multicolumn{4}{|c|}{ Interventiegroep $n=144$} & \multicolumn{4}{|c|}{ Controlegroep $n=128$} \\
\hline & & & \multicolumn{2}{|c|}{ verwezen } & & & \multicolumn{2}{|c|}{ venwezen } \\
\hline & & & $\mathrm{n}$ & rij \% & & & $\mathrm{n}$ & rij \% \\
\hline 03. rug & $n=$ & 13 & 6 & 46 & $\mathrm{n}=$ & 6 & 5 & 83 \\
\hline 08. schouder & $n=$ & 21 & 3 & 14 & $\mathrm{n}=$ & 19 & 12 & 63 \\
\hline 10. elleboog & $\mathrm{n}=$ & 10 & 1 & 10 & $\mathrm{n}=$ & 10 & 8 & 80 \\
\hline 12. hand & $\mathrm{n}=$ & 6 & 0 & 0 & $\mathrm{n}=$ & 6 & 6 & 100 \\
\hline 13. houp & $\mathrm{n}=$ & 7 & 5 & 71 & $n=$ & 6 & 4 & 67 \\
\hline 15. knie & $\mathrm{n}=$ & 44 & 22 & 50 & $n=$ & 39 & 27 & 69 \\
\hline 17. voet & $\mathrm{n}=$ & 15 & 3 & 20 & $n=$ & 9 & 8 & 89 \\
\hline alle klachten/diagr & & & & 35 & & & & 68 \\
\hline
\end{tabular}

In bovenstaande tabel zien we dat vooral de klachten met de ICPC-codes 8 (schouder), 10 (elleboog), 12 (hand) en 17 (voet) voor de interventiegroep qua verwijspercentage relatief sterk afwijken van de controlegroep.

Bij de klachten 3 (rug) en 15 (knie) wordt een minder groot verschil gezien, terwijl bij 13 (heup) tussen beide groepen geen verschil wordt gevonden.

Uit de multivariate analyses (bijlagen 26-28,30,31) blijkt dat rugklachten vaker als recidief voorkwamen, terwijl de huisartsen bij deze klachten relatief minder 
vaak 'vaardigheden ontwikkelen' als motief voor het gezamenlijk consult noteerden. $\mathrm{Bij}$ schouderklachten was er bij de huisartsen een significant grotere kans op het motief 'vaardigheden ontwikkelen', evenals bij tendinitiden.

Het motief 'vaardigheden ontwikkelen' werd minder vaak door de huisartsen genoteerd bij knieklachten. Bij heupklachten was er een grotere kans op 'overleg' als motief van de huisartsen voor het gezamenlijk consult.

Tijdens de eindconsulten na één jaar werd aan de huisartsen gevraagd of zij de destijds gepresenteerde klacht, tijdens het afgelopen jaar daarna nog (bij andere patiënten) waren tegengekomen (tabel 3.1.2.1.VII) (zie ook paragraaf 4.2.).

De beantwoording van deze vraag geeft een resultaat van $59 \%$ en $56 \%$ voor respectievelijk de interventie- en controlegroep.

Wanneer de resultaten van de bij de introomconsulten gestelde vraag naar 'al dan niet vaak voorkomen van de aangeboden klachten' worden vergeleken met de bij de eindconsulten aan de huisartsen gestelde vraag in welke mate de klachten tijdens één jaar opnieuw werden gezien', blijken de antwoorden sterk overeen te komen.

Tabel 3.1.2.1.VIII Vraag tijdens eindconsulten aan huisartsen gesteld:

Heeft $\mathrm{u}$ in het afgelopen jaar een identiek probleem gezien?

\begin{tabular}{lcc}
\hline & $\begin{array}{c}\text { Interventiegroep* } n=144 \\
\%\end{array}$ & $\begin{array}{c}\text { Controlegroep* } n=128 \\
\%\end{array}$ \\
\hline ja & 59 & 56 \\
nee & 41 & 40 \\
niet ingevuld & 0 & 4 \\
\hline
\end{tabular}

- Chi-kwadreattoets $p=0.96$ (geloetst mel item 'niet ingevuld' als missing)

\section{DISCUSSIE}

De interventie- en controlegroep komen qua achtergrondgegevens en uitval sterk overeen. Over het geheel genomen blijkt dat in de gezamenlijk consultgroep significant minder vaak werd verwezen dan in de controlegroep. Op het instroommoment verschilden duur van de klacht en behandelingsduur niet voor interventie- en controlegroep. Wel schatten de huisartsen de duur van de klachten, conform de resultaten van eerder onderzoek, gemiddeld minder lang dan de patiënten zelf doen. $(4,5)$

Kort bestaande en behandelde klachten waren in de groepen in een minderheid (respectievelijk $20 \%$ en $13 \%$ ) aanwezig. De uitkomsten komen overeen met onze verwachting dat vooral patiënten met langer bestaande klachten en/of langere behandelingsduur volgens huisartsen in aanmerking komen voor een gezamenlijk consult. Bij patiënten waarbij op het instroommoment de klachten al langer bestonden, bleek dat de kans op klachtenvrij worden na één jaar relatief kleiner was en reageerden zowel de huisartsen (bij patiënten van de interventiegroep) als de orthopaedisch chirurgen (bij patiënten van de controlegroep) met het aanvragen van relatief meer röntgenfoto's. Deze toename van diagnostische verrichtin- 
gen en de kleinere kans om klachtenvrij te worden, is mogelijk toe te schrijven aan de, ook uit eerder onderzoek bekende, neiging van huisartsen en specialisten vooral diagnostisch onderzoek aan te vragen bij onzekere diagnoses en/of chronische ziekten. (12-14)

Het valt op dat de 'vaak' voorkomende klachten relatief weinig voor het gezamenlijk consult werden aangeboden (resp. $15 \%$ en $18 \%$ ). Dit lijkt verklaarbaar vanuit de veronderstelling dat het gezamenlijk consult doorgaans oplossingen zal bieden bij voor de huisarts moeilijke situaties en/of klachten die niet vaak voorkomen. Voor klachten waarmee zij in de praktijk dikwijls worden geconfronteerd, hebben zij waarschijnlijk doorgaans reeds een standaard oplossing voorhanden, hetgeen de kans op behandeling door middel van een gezamenlijk consult verkleint. Aan interventie- en controlegroep werden patiënten met vrijwel hetzelfde type klachten aangeboden. Het aantal verwijzingen verschilde sterk afhankelijk van het type klacht. De belangrijkste verschillen in verwijzing zagen we bij schouder-, elleboog-, hand- en voetklachten.

$\mathrm{Bij}$ de gezamenlijk consultpatiënten werd daarbij opmerkelijk minder vaak verwezen. $\mathrm{Bij}$ rug-en knieklachten waren de verwijzingen in de interventiegroep frequenter (ongeveer $50 \%$ ) dan gemiddeld (35\%) voor deze groep. Bij heupklachten zien we qua verwijzingen vrijwel geen verschil tussen beide groepen.

De verschillende verwijspercentages bij de onderscheiden klachrcategorieën zijn wellicht te verklaren vanuit de veronderstelling dat klachten van schouder, elleboog, hand en voet vaak het gevolg zijn van een door huisartsen goed te behandelen tendinitis of bursitis. Bij knieklachten zal frequenter gebruik worden gemaakt van specialistische onderzoektechnieken (bijvoorbeeld arthroscopie), hetgeen zal resulteren in een relatief groot aantal verwijzingen. Heup- en rugklachten, mogelijk als gevolg van degeneratieve processen (bijvoorbeeld coxarthrosis), zien we nog vaker uitmonden in verwijzingen.

Deze hypothesen stemmen overeen met de resultaten van de multivariate analyses, waaruit bleek dat schouderklachten en tendinitiden vergezeld werden van het motief 'vaardigheden ontwikkelen', terwijl dit bij rug- en knieklachten juist tegenovergesteld was. Dit past ook bij de bevinding dat de injectierherapie door huisartsen bij patiënten van de interventiegroep vooral werd toegepast in combinatie met het motief 'vaardigheden ontwikkelen' (zie pagina's 71 en 90).

$\mathrm{Bij}$ rugklachten was er dikwijls sprake van recidief en bij heupklachren werd vaker 'overleg' gewenst, hetgeen eveneens het groter aantal verwijzingen bij deze klachten zou kunnen verklaren.

\section{CONCLUSIES}

$\mathrm{Na}$ het gezamenlijk consult (=interventiegroep) is significant minder vaak verwezen dan bij de gebruikelijke zorg (controlegroep).

- Voor het gezamenlijk consult kwamen vooral patiënten met langer bestaande en behandelde klachten in aanmerking. Patiënten bleken na één jaar significant minder frequent klachtenvrij te zijn, wanneer de klachten op het moment van instroom reeds zeer lang bestonden. Bovendien werd bij deze patiënten, vooral in de gebruikelijke zorg, vaker röntgenonderzoek verricht. 
- De klachten aangeboden voor het gezamenlijk consult kwamen volgens de huisartsen overwegend 'regelmatig' tot 'zelden' voor in de huisartspraktijk.

- De klachten welke het frequentst voor het gezamenlijk consult werden aangeboden, betreffen knie-, schouder-, voet/teen-, rug-, elleboog-, heup-en handklachten.

- De daling van het aantal verwijzingen na het gezamenlijk consult was verschillend voor de onderscheiden klachten. Vooral patiënten met schouder-, elleboog-, hand- en voetklachten, werden in de interventiegroep opvallend minder verwezen. Een voor de hand liggende verklaring is dat vooral bij dit type klachten door het gezamenlijk consult op adequate wijze tegemoet kan worden gekomen aan het motief 'vaardigheden ontwikkelen', waardoor verwijzingen worden voorkomen.

\subsubsection{Klachtbeleving}

\section{INLEIDING}

Binnen de gezondheidszorg speelt de klachtbeleving bij de vragen om hulp een belangrijke rol.

Pijn, hinder, angst of ongerustheid zijn bij $85-90 \%$ van de mensen de belangrijkste reden om de dokter te raadplegen. (15-19)

Ongerustheid en angst over de betekenis en gevolgen van een ervaren klacht vormen bij ongeveer $60 \%$ van de patiënten een belangrijke reden om de huisarts te raadplegen. (20-25)

Belleman (26) is van mening dar uitsluitend medisch somatisch onderzoek mogelijk wel de arts, echter vaak niet de patiënt geruststelt. Ditzelfde zou meestal gelden voor verwijzing.

Volgens De Jonghe (27) is het belangrijk dat huisartsen angst en ongerustheid herkennen, om vervolgens hun informatieverstrekking en interventie daarop af te stemmen. Engelsman c.s. (25) vonden in hun onderzoek naar ongerustheid van naar diverse specialismen verwezen patiënten, dat na drie maanden bij de helft van de patiënten de ongerustheid nog aanwezig was. Geruststelling van de patiënt speelde bij $36 \%$ van de verwijsbeslissingen van de huisarts een belangrijke rol. Naarmate klachtbeleving bij klachten van het bewegingsapparaat hoger scoort, lijkt het logisch dat een zwaarder beroep wordt gedaan op de gezondheidszorg. Om deze redenen zijn last of hinder, pijn, ernst, verergering, bezorgdheid, mate waarin de patiënt zich gerustgesteld voelt en het inzicht van de patiënt in de oorzaak van de klacht in het onderzoek opgenomen als variabelen.

Omdat naar verwachting klachtbeleving van invloed is op het verdere verloop, mocht hieromtrent tussen interventie- en controlegroep op het instroommoment geen belangrijke verschillen aanwezig zijn.

De verschillende belevingsvariabelen zijn gescoord op een 5-puntsschaal, behalve de variabele 'de laatste tijd verergering' welke door middel van een 7-puntsschaal werd gescoord.

$\mathrm{Bij}$ het instroomconsult werden de variabelen door patiënten en huisartsen gescoord, bij de eindconsulten beantwoordden uitsluitend de patiënten een aantal van deze vragen. 
Daardoor is het mogelijk tussen instroom- en eindconsult eventuele verschillen van een aantal belevingsvariabelen vast te stellen.

Vragen over 'geruststelling' en 'duidelijkheid' werden door de patiënten direct na de instroomconsulten beantwoord, terwijl de patiënten van de interventiegroep de vragen na het gezamenlijk consult nogmaals beantwoordden. Dit laatste is gedaan om de mogelijke invloed van het gezamenlijk consult op de mate waarin patiënten gerustgesteld zijn over of inzicht hebben in de klacht te kunnen vaststellen.

\section{RESULTATEN}

\section{Last of hinder}

De resultaten voor de variabelen 'last of hinder', 'pijn', 'ernst', 'verergering' en 'bezorgdheid' over de klachten vertonen voor een belangrijk deel een overeenkomstig profiel.

Om deze reden en omdat de bivariate analyses overeenkomstige resultaten te zien geven, is voor een aantal onderdelen uitsluitend de variabele 'last of hinder' beschreven. Bovendien zijn de variabelen last/hinder, ernst en gerustgesteld geanalyseerd door middel van de multivariate analyses.

Tabel 3.1.2.2.I Mate van 'last of hinder' volgens patiënt tijdens instroom- en eindconsult en volgens huisarts bij instroomconsult.

\begin{tabular}{|c|c|c|c|c|c|c|c|c|c|c|c|c|}
\hline \multirow[b]{3}{*}{ Last of hinder } & \multicolumn{4}{|c|}{ Interventiegroep $n=144$} & \multicolumn{4}{|c|}{ Controlegroep $n=128$} & \multirow{2}{*}{\multicolumn{2}{|c|}{$\begin{array}{c}\text { Interven- } \\
\text { tiegroep } \\
n=144 \\
\text { huisarts } \\
\text { tijdens } \\
\text { instroom- } \\
\text { consult }\end{array}$}} & \multirow{2}{*}{\multicolumn{2}{|c|}{$\begin{array}{c}\begin{array}{c}\text { Controle } \\
\text { groep } \\
n=128\end{array} \\
\text { huisarts } \ldots \\
\text { tijdens } \\
\text { Instroom- } \\
\text { consult }\end{array}$}} \\
\hline & \multicolumn{2}{|c|}{$\begin{array}{l}\text { patiēnt" } \\
\text { tijdens } \\
\text { instroom- } \\
\text { consult }\end{array}$} & \multicolumn{2}{|c|}{$\begin{array}{l}\text { patiênt"* } \\
\text { tijdens } \\
\text { eind- } \\
\text { consult }\end{array}$} & \multicolumn{2}{|c|}{$\begin{array}{c}\text { patiönt" } \\
\text { tijdens } \\
\text { instroom- } \\
\text { consult }\end{array}$} & \multicolumn{2}{|c|}{$\begin{array}{l}\text { patient }{ }^{* *} \\
\text { tijdens } \\
\text { eind. } \\
\text { consult }\end{array}$} & & & & \\
\hline & n & $\%$ & $n$ & $\%$ & $n$ & $\%$ & $n$ & $\%$ & $n$ & $\%$ & $n$ & $\%$ \\
\hline zeer veel & 31 & 22 & 9 & 6 & 33 & 26 & 9 & 7 & 12 & 8 & 6 & 5 \\
\hline voel & 69 & 48 & 31 & 22 & 59 & 46 & 37 & 28 & 71 & 50 & 70 & 54 \\
\hline matig & 36 & 25 & 45 & 31 & 27 & 21 & 34 & 27 & 55 & 38 & 46 & 36 \\
\hline weinig & 5 & 3 & 23 & 16 & 3 & 2 & 25 & 20 & 4 & 3 & 4 & 3 \\
\hline geen & 3 & 2 & 35 & 24 & 4 & 3 & 23 & 18 & 2 & 1 & 2 & 2 \\
\hline niet ingevuld & 0 & 0 & 1 & 1 & 2 & 2 & 0 & 0 & 0 & 0 & 0 & 0 \\
\hline totaal & 144 & 100 & 144 & 100 & 128 & 100 & 128 & 100 & 144 & 100 & 128 & 100 \\
\hline
\end{tabular}

- Chi-kwadraattoets $p=0.78$

* Chi-kwadraattoets $p=0.36$

*.* Chi-kwadraattoets $p=0.92$

(getoetst met item 'niet ingevuld' als missing en de items 'zeer veel' en 'veel' samengevoegd, evenals de items 'weinig' en 'geen': $d t=2$ ).

Wilcoxon signed-rank test patient-huisarts bij instroom: Interventiegroep $p=<.01$; Controlegroep $p=<.01$ Wilcoxon signed-rank test patient instroom-eindconsult: Interventiegroep $p=<.01$; Controlegroep $p=<.01$ 
In deze tabel blijken de patiënten-scores bij de instroomconsulten qua verdeling over de verschillende items voor beide groepen sterk overeen te komen, waarbij voornamelijk de categorieën 'zeer veel', 'veel' en 'matig' hoog scoren.

Ook de scores van de huisartsen met betrekking tor 'last of hinder' tijdens de instroomconsulten waren voor beide groepen sterk overeenkomstig, waarbij echter conform de resultaten van eerder onderzoek bleek dat de huisartsen de last of hinder beduidend (significant $\mathrm{p}=<.01$ voor beide groepen) lager inschatten dan de patiënten zelf deden. (27-29)

Wanneer we de resultaten ten aanzien van 'last of hinder' tijdens het instroomconsult vergelijken met die van het eindconsult zien we voor beide groepen patiënten na één jaar vrijwel dezelfde significante $(p=<.01$ voor beide groepen) vooruitgang. 'Last of hinder' scoorde bij de instroom hoog. Wel had in beide groepen bij het eindconsult ongeveer $30 \%$ van de patiënten nog 'veel' tot 'zeer veel' last of hinder. Voorts blijkt dat de mate van last en hinder geen voorspellende waarde heeft ten aanzien van het al of niet verwijzen.

Dezelfde bevindingen gelden voor de variabelen 'pijn', 'ernst' en 'verergering', waarvan we de tabellen hier niet hebben opgenomen. Uit de multivariate analyses (zie bijlage 18) blijkt dat de huisartsen in beide groepen vaker medicatie voorschreven wanneer patiënten de klachten ernstiger achtten. Patiënten in de interventiegroep werden bij ernstige klachten vaker door de huisartsen naar de fysiotherapeut verwezen (OR 2.60, 95\% CI 1.19-5.69).

\section{Geruststelling}

De resultaten voor de mate van 'geruststelling' gemeten na de instroomconsulten van de 'interventie-' en 'controlegroep' zien we in tabel 3.1.2.2.II, waarbij wel de relatie met het 'al dan niet verwezen zijn' is aangegeven.

Tabel 3.1.2.2.II Mate van geruststelling volgens patiënt per groep bij het instroomconsult, in relatie tot verwijzingen.

\begin{tabular}{|c|c|c|c|c|c|c|c|c|}
\hline \multirow{3}{*}{$\begin{array}{l}\text { Mate van gerust- } \\
\text { stelling }\end{array}$} & \multicolumn{4}{|c|}{ Interventiegroep $n=144$} & \multicolumn{4}{|c|}{ Controlegroep $n=128$} \\
\hline & \multicolumn{2}{|c|}{ totaal* } & \multicolumn{2}{|c|}{ verwezen } & \multicolumn{2}{|c|}{ totaal* } & \multicolumn{2}{|c|}{ verwezen } \\
\hline & $n$ & $\%$ & $n$ & rij \% & $n$ & $\%$ & $n$ & rij \% \\
\hline volledig & 12 & 8 & 3 & 25 & 13 & 10 & 9 & 69 \\
\hline voldoende & 40 & 28 & 11 & 28 & 36 & 28 & 22 & 61 \\
\hline matig & 43 & 30 & 14 & 33 & 31 & 24 & 24 & $\pi$ \\
\hline weinig & 22 & 15 & 13 & 59 & 19 & 15 & 8 & 42 \\
\hline niet & 27 & 19 & 10 & 37 & 29 & 23 & 24 & $83^{* *}$ \\
\hline totaal & 144 & 100 & 51 & 35 & 128 & 100 & 87 & 68 \\
\hline
\end{tabular}

Chi-kwadraattoets $p=0.81$

* Chi-kwadraattoets $p=0.03$ 
In deze tabel zien we tussen interventie- en controlegroep geen belangrijke verschillen voor de mate waarin de patiënten zich na de instroomconsulten gerustgesteld voelden. Opvallend groot zijn de aantallen patiënten die 'niet' 'weinig' en 'matig' gerustgesteld waren: samen bedragen zij respectievelijk $64 \%$ en $62 \%$ van de interventie- respectievelijk controlegroep.

Verwijzingen waren frequent en significant $(p=0.03)$ afwijkend van de overige controlegroeppatiënten aanwezig bij de 'niet gerustgestelde' patiënten ( $83 \%$ van de 'niet gerustgestelden').

Uit de multivariate analyses (zie bijlage 19) blijkt dat de patiënten in één jaar significant meer verwijzingen voor fysiotherapie kregen, wanneer de huisarts voor het gezamenlijk consult het motief 'patiënt ongerust' aanvoerde (OR 2.99, 95\% CI 1.40-6.36).

Bij vergelijking van gegevens van de interventiegroep vóór en na het gezamenlijk consult (tabel 3.1.2.2.III), zien we dat het aantal 'matig', 'weinig' en 'niet gerustgestelde' patiënten na het gezamenlijk consult significant $(p=<.01)$ is afgenomen.

Tabel 3.1.2.2.III Mate van geruststelling volgens patiënten van de interventiegroep na instroomconsult en na gezamenlijk consult.

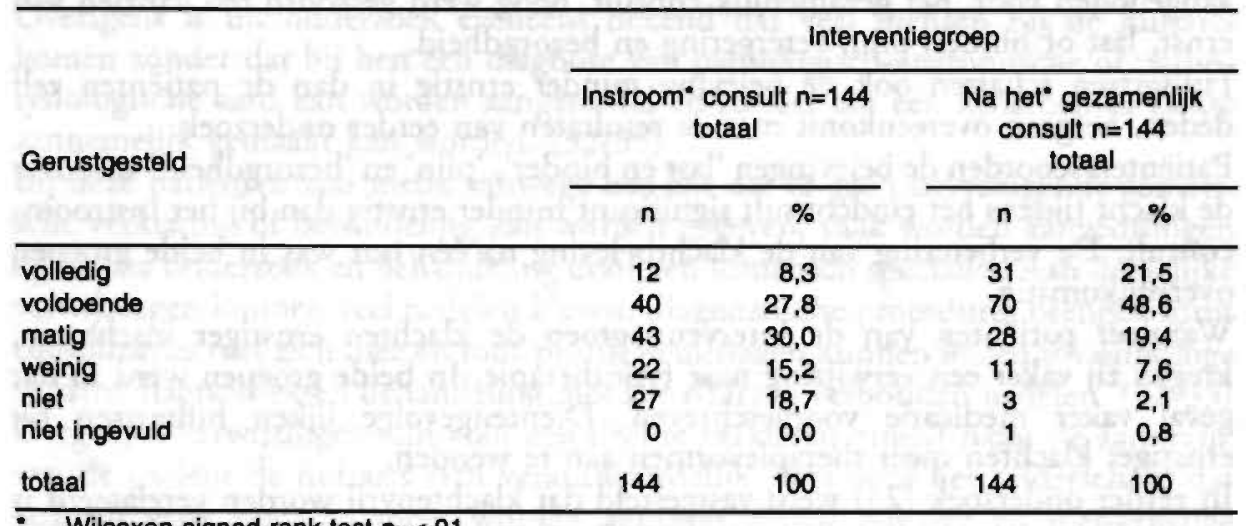

Vergelijkbare effecten na het gezamenlijk consult zagen we voor de variabele 'inzicht in de klacht' (tabel 3.1.2.2.IV). 
Tabel 3.1.2.2.IV Mate waarin patiënten menen duidelijkheid te hebben verkregen over de klacht na het instroom- en gezamenlijk consult.

\begin{tabular}{|c|c|c|c|c|c|c|}
\hline \multirow{3}{*}{ Inzicht in de klacht } & \multicolumn{4}{|c|}{ Interventiegroep $n=144$} & \multirow{2}{*}{\multicolumn{2}{|c|}{$\begin{array}{l}\text { Controlegroep } n=128 \\
\text { Instroom }{ }^{*} \text { consult }\end{array}$}} \\
\hline & \multicolumn{2}{|c|}{ Instroom* Consult"* } & \multicolumn{2}{|c|}{$\begin{array}{c}\text { Na het gezamenlijk } \\
\text { consult** }\end{array}$} & & \\
\hline & $n$ & $\%$ & n & $\%$ & n & $\%$ \\
\hline volledig & 28 & 19,4 & 42 & 29,1 & 22 & 17,2 \\
\hline voldoende & 28 & 19,4 & 47 & 32,5 & 25 & 19,5 \\
\hline matig & 16 & 11,1 & 22 & 15,3 & 20 & 15,6 \\
\hline weinig & 24 & 16,7 & 8 & 5,6 & 18 & 14,1 \\
\hline niet & 47 & 32,6 & 24 & 16,7 & 43 & 33,6 \\
\hline niet ingevuld & 1 & 0,8 & 1 & 0,8 & 0 & 0 \\
\hline totaal & 144 & 100 & 144 & 100 & 128 & 100 \\
\hline
\end{tabular}

- Chi-kwadraattoets $p=0.82$

(getoetst met item 'niet ingevuld' als missing).

** Wilcoxon signed-rank test $p=<.01$

\section{DISCUSSIE}

De resultaten met betrekking tot de klachtbeleving laten zien dat bij klachten aangeboden voor 'het gezamenlijk consult' hoog werd gescoord ten aanzien van ernst, last of hinder, pijn, verergering en bezorgdheid.

Huisartsen schatten ook de beleving minder ernstig in dan de patiënten zelf deden, hetgeen overeenkomt met de resultaten van eerder onderzoek.

Patiënten scoorden de belevingen 'last en hinder', 'pijn' en 'bezorgdheid' van/over de klacht tijdens het eindconsult significant minder ernstig dan bij het instroomconsult. De verbetering van de klachtbeleving na één jaar was in beide groepen overeenkomstig.

Wanneer patiënten van de interventiegroep de klachten ernstiger inschatten, kregen zij vaker een verwijzing naar fysiotherapie. In beide groepen werd in dat geval vaker medicatie voorgeschreven. Dientengevolge lijken huisartsen bij ernstiger klachten meer therapievormen aan te wenden.

In eerder onderzoek (25) werd vastgesteld dat klachtenvrij worden gerelateerd is aan de mate van geruststelling. In het effectiviteitsonderzoek betreft het geruststelling tijdens de instroom gerelateerd aan klachrenvrij zijn na één jaar. Wellicht levert geruststelling een belangrijke bijdrage aan het klachtenvrij worden. $\mathrm{Na}$ deelname aan het gezamenlijk consult lijkt de ongerustheid te verminderen en mede daardoor daalt wellicht het aantal verwijzingen. De afname van de ongerustheid ontstaat mogelijk door de meer complete inventarisatie en uitdieping van klachten en achtergronden en de wijze van onderzoek en samenspraak met de patiënt, inherent aan het gezamenlijk consult. Het ontbreken van geruststelling in de controlegroep wordt opvallend vaak gevolgd door verwijzen, hetgeen overeenkomt met eerder onderzoek. (22) 
- Patiënten geïndiceerd voor het gezamenlijk consult scoorden hoog met betrekking tot last of hinder, pijn, ernst, verergering en bezorgdheid.

- 'Ernstiger' klachten werden vaker behandeld met medicatie en fysiotherapie.

- $\mathrm{Na}$ éen jaar is de klachtbeleving in beide groepen duidelijk verbeterd.

- Niet gerustgestelde patiënten werden bij gebruikelijke zorg vaker verwezen.

- $\mathrm{Na}$ het gezamenlijk consult was eventueel aanwezige ongerustheid belangrijk verminderd.

\subsubsection{Pathologie gerelateerd aan de klacht}

\section{INLEIDING}

Bij een belangrijk deel van de klachten waarmee huisartsen worden geconfronteerd is er onduidelijkheid over de oorzak van de klachten. Dit geldt eveneens voor klachten van het bewegingsapparaat. Volgens Klip zal het oordeel van de huisarts of een klacht een somatische dan wel een psychosociale oorzaak heeft, gevolgen hebben voor de behandelingsstrategie. (30)

Van der Meer beschreef een samenhang tussen chronisch huisartsbezoek en het niet puur lichamelijk begrijpbaar zijn van de klacht. Daarbij vond hij een hogere kans op psychische problematiek. (31)

Overigens is uit onderzoek eveneens bekend dat veel mensen bij de huisarts komen zonder dat bij hen een diagnose van pathologisch-anatomische of pathofysiologische aard kan worden aangetoond en zonder dat een lichamelijke ziekte aannemelijk gemaakt kan worden. (32-35)

Bij deze patiënten zou mede vanwege het feit dat er geen bevredigende somatische verklaring of behandeling kan worden gegeven, vaak worden aangedrongen op verder onderzoek en behandeling door een somarisch specialist. Aan dergelijke verwijzingen kunnen veel nadelen kleven: diagnostische procedures brengen soms complicaties met zich mee en fout-positieve uitslagen kunnen leiden tot onnodige verdere diagnostiek en behandeling met alle daaraan verbonden nadelen. (32-35) Dergelijke verwijzingen zijn voor een deel te verklaren omdat naast de aandrang van de patiënt de huisarts zich verantwoordelijk weet voor het onderscheid dat ook bij vage klachten moet worden gemaakt tussen ernstige en niet-ernstige aandoeningen. $(30,35,36)$

Omdat klachten voorafgaand aan het gezamenlijk consult eveneens vaak lang bestaan en verwacht kan worden dat de oorzaak van de klachten dikwijls onduidelijk is, leek het van belang na te gaan in welke mate huisartsen meenden dat aan de klacht duidelijke pathologie ten grondslag lag.

Om bovenstaande redenen werd tijdens ieder eindconsult aan de huisarts de vraag gesteld in hoeverre hij van mening was dat de klacht veroorzaakt was door herkenbare pathologie. De vraag aan de huisarts luidde: 'Is bij de patiënt in de loop van éen jaar in relatie tot de klacht evidente pathologie gevonden?'. 


\section{RESULTATEN}

$\mathrm{Na}$ het eindconsult werd op de vraag naar in de loop van tén jaar gevonden evidente pathologie, gerelateerd aan de klacht, in $56 \%$ en $62 \%$ van de gevallen positief geantwoord, respectievelijk voor de interventiegroep $(n=144)$ en de controlegroep $(n=128)$.

In tabel 3.1.2.3.I zien we dezelfde gegevens ingedeeld naar het criterium verwezen-niet verwezen.

Tabel 3.1.2.3.I Mate waarin tijdens het eindconsult volgens de huisarts patiënten met aan de klacht gerelateerde pathologie binnen één jaar zijn verwezen.

\begin{tabular}{|c|c|c|c|c|c|c|c|c|}
\hline \multirow[b]{3}{*}{ Pathologie } & \multicolumn{4}{|c|}{ Interventiegroep $n=144$} & \multicolumn{4}{|c|}{ Controlegroep $n=128$} \\
\hline & \multicolumn{2}{|c|}{ totaal } & \multicolumn{2}{|c|}{ venwezen } & \multicolumn{2}{|c|}{ totaal } & \multicolumn{2}{|c|}{ verwezen } \\
\hline & $n$ & $\%$ & $n$ & rij \% & $n$ & $\%$ & $n$ & rij \% \\
\hline $\begin{array}{l}\text { ja } \\
\text { nee } \\
\text { niet ingevuld }\end{array}$ & $\begin{array}{r}80 \\
64 \\
0\end{array}$ & $\begin{array}{r}56 \\
44 \\
0\end{array}$ & $\begin{array}{r}30 \\
21 \\
0\end{array}$ & $\begin{array}{r}38 \\
33 \\
0\end{array}$ & $\begin{array}{r}80 \\
47 \\
1\end{array}$ & $\begin{array}{r}62 \\
37 \\
1\end{array}$ & $\begin{array}{c}63 \\
24^{\circ} \\
0\end{array}$ & $\begin{array}{r}79 \\
51 \\
0\end{array}$ \\
\hline total & 144 & 100 & 51 & 35 & 128 & 100 & 87 & 68 \\
\hline
\end{tabular}

- Chi-kwadraattoets $p=<.01$

(getoetst met item 'niet ingevuld' als missing).

We zien dat in de controlegroep significant minder patiënten 'zonder pathologie' werden verwezen dan patiënten 'met pathologie'.

In de interventiegroep werden patiënten met pathologie vrijwel even vaak verwezen als patiènten zonder pathologie.

Uit de multipele logistische regressie analyses blijkt dat bij afwezigheid van pathologie in de controlegroep minder patiënten werden verwezen (O.R. 0.25 , $95 \%$ C.I. $0.10-0.58)$.

\section{DISCUSSIE}

De door de huisartsen in de loop van één jaar geconstateerde pathologie, gerelateerd aan de klacht, deed zich in beide groepen frequent en vrijwel even vaak (ongeveer 60\%) voor. Dit is mede gezien onderzoek elders een betrekkelijk hoog percentage. (32)

In de controlegroep zien we bij verdenking van aan de klacht gerelateerde pathologie significant meer verwijzingen.

Blijkbaar zijn huisartsen in de gebruikelijke zorg vaker geneigd te verwijzen wanneer aan de klacht pathologie is gerelateerd. Op zichzelf lijkt dit een zinvolle gewoonte.

$\mathrm{Na}$ het gezamenlijk consult lijkt het voor huisartsen en patiënten blijkbaar meer acceptabel om ook bij klachren gerelateerd aan pathologie, minder vaak te verwijzen. 
Huisartsen voelen zich na een gezamenlijk consult blijkbaar beter geëquipeerd om patiënten met klachten waaraan pathologie is gerelateerd, zelfstandig verder te behandelen.

\section{CONCLUSIES}

Pathologie gerelateerd aan de ingangsklacht deed zich volgens de huisarts bij meer dan de helft van de voor het gezamenlijk consult geselecteerde patiënten voor. $\mathrm{Na}$ het gezamenlijk consult werden ook patiënten met dergelijke klachten relatief minder vaak verwezen dan in de gebruikelijke zorg. In de gebruikelijke zorg werden patiënten zonder duidelijke pathologie minder vaak verwezen dan diegenen met mogelijke pathologie.

\subsubsection{Klacht en afwljkingen: vastgesteld door lichamelljk onderzoek}

\section{INLEIDING}

Alle patiënten zijn bij instroom-, gezamenlijke en eindconsulten naar aanleiding van de klacht gericht lichamelijk onderzocht.

Dit gebeurde bij beide groepen patiënten aan de hand van een onderzoeklijst (zie bijlagen 2B,6,9).

Met behulp van de onderzoeklijst diende een zo eenvoudig en nauwkeurig mogelijke meting voor de klachten van het bewegingsapparaat te worden verkregen.

Getracht is een aantal bevindingen en functies zo objectief mogelijk te laten scoren.

De onderzoeksbevindingen betroffen zwelling, atrofie en pijnlijke palpatie. De functies werden gescoord door beoordeling van de beweeglijkheid en met de items 'passieve beweeglijkheid beperkt', 'actieve beweeglijkheid beperkt', 'kracht beperkt' en 'testen positief. Elk positief gescoord item van de onderzoeklijst werd gewaardeerd met één punt.

$\mathrm{Bij}$ de instroom vulde de orthopaedisch chirurg na een gericht onderzoek de onderzoeklijst in bij de patiënten van de interventiegroep. De huisarts deed hetzelfde bij de patiënten van de controlegroep.

Vanwege de studie-opzet was het niet mogelijk de patiënten van de controlegroep ten tijde van het instroommoment door een orthopaedisch chirurg te laten onderzoeken.

Een dergelijk onderzoek zou naar verwachting een aantal niet te voorziene gevolgen kunnen hebben voor de verdere zorgverlening en komt niet overeen met de 'gebruikelijke zorg', welke voor de controlegroep volgens de projectopzet zou moeten plaatsvinden.

Om na te gaan in hoeverre huisarts of orthopaedisch chirurg met behulp van de onderzoeklijst verschillende uitslagen noteerden (inter-observer verschillen), hebben 3 huisartsen en 2 orthopaedisch chirurgen tijdens de eindconsulten 11 maal de onderzoeklijsten onafhankelijk van elkaar ingevuld.

Wanneer we de huisartsgeneeskundige waarnemingen uitzetten tegen de waarnemingen van de orthopaedisch chirurgen bij dezelfde patiënten (resulterend in 66 paar waarnemingen), kunnen we de overeenkomst van het algemene oordeel van 
de huisartsen en het algemene oordeel van de orthopaeden uitdrukken in een kappawaarde van 0.72 .

Om deze reden worden de instroom-onderzoeksgegevens van de huisartsen en orthopaedisch chirurgen als gelijkwaardig beschouwd.

Tijdens het eindconsult werd de patiënt door een hem onbekende orthopaedisch chirurg klachtgericht onderzocht, tenzij de patiënt klachtenvrij was en er derhalve geen onderzoek werd verricht.

De subjectief ervaren ADL-functies werden door middel van de S.I.P.-enquêtelijst gescoord (zie bijlagen 1A,1B,7A,7B). (Zie paragraaf 3.1.5.).

\section{RESULTATEN}

De totaalscores van de onderzoeklijsten van de instroom- en gezamenlijke consulten van beide groepen zien we in figuur 3.1.2.4.I. In figuur 3.1.2.4.II zien we de scores van de eindconsulten van beide groepen.

Figuur 3.1.2.4.I Resultaten gericht lichamelijk onderzoek tijdens instroomconsulten.

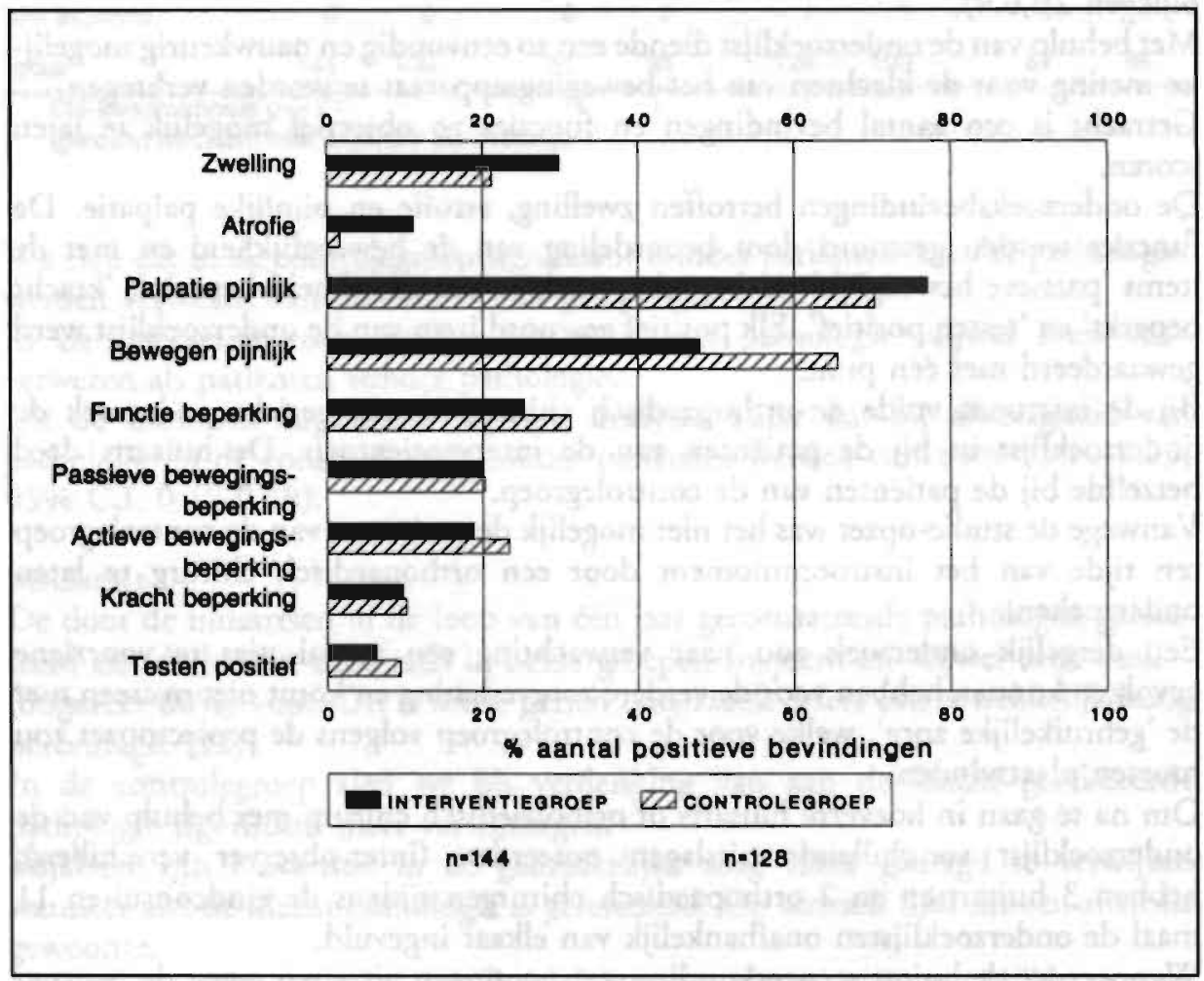

Percenteges positief (afwijkend) gescoorde bevindingen

Totaal Interventiegroep:

$27,4 \%$

Totaal Controlegroep:

$28,1 \%$ 
Figuur 3.1.2.4.II Resultaten gericht lichamelijk onderzoek tijdens eindconsulten.

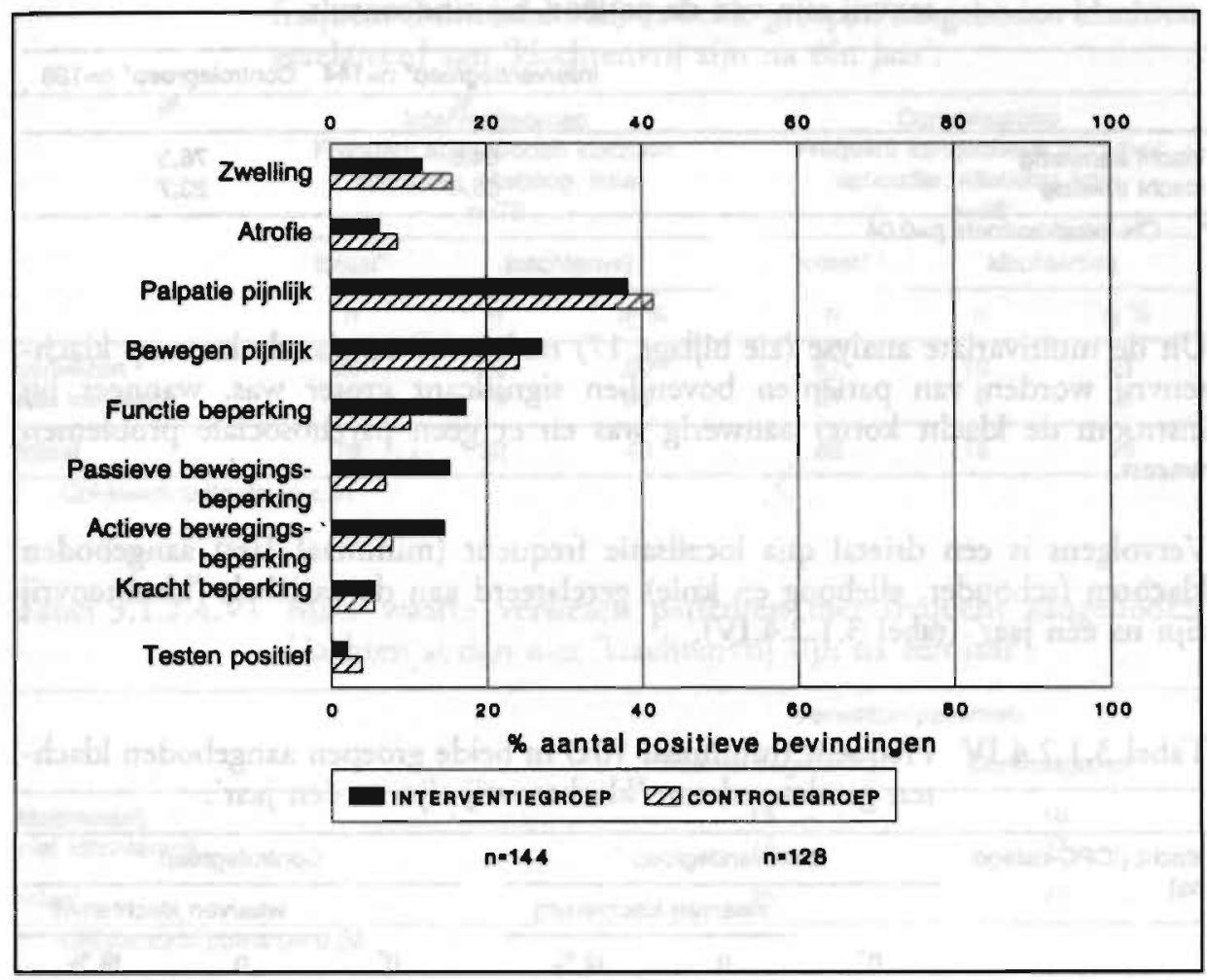

Percentages positief (afwijkend) gescoorde bevindingen

Totaal Interventiegroep:

$15,3 \%$

Totaal Controlegroep:

$13,8 \%$

Uit beide figuren is op te maken dat de lichamelijke onderzoeksgegevens bij de instroom- en eindconsulten tussen de twee groepen niet belangrijk verschilden. Bij beide groepen is na én jaar een vrijwel overeenkomstige verbetering opgetreden.

Het oordeel in hoeverre de patiënten na één jaar klachtenvrij waren, geeft eveneens inzicht in de gezondheidstoestand in relatie tot de gepresenteerde klacht (tabel 3.1.2.4.III).

Bij de eindconsulten bleken volgens de orthopaedisch chirurgen van de interventiegroeppatiënten $35,4 \%$ klachtenvrij en $23,7 \%$ van de controlepatiënten, hetgeen een significant verschil $(\mathrm{p}=0.04)$ russen beide groepen betekent. 
Tabel 3.1.2.4.III Oordeel van de orthopaedisch chirurg over al dan niet klachtenvrij zijn van de patiënt, bij eindconsult.

\begin{tabular}{lcc}
\hline & $\begin{array}{c}\text { Interventiegroep* } n=144 \\
\%\end{array}$ & $\begin{array}{c}\text { Controlegroep* } n=128 \\
\%\end{array}$ \\
\hline klacht aanwezig & 64,6 & 76,3 \\
klacht afwezig & 35,4 & 23,7 \\
\hline
\end{tabular}

Chi-kwadraattoets $p=0.04$

Uit de multivariate analyse (zie bijlage 17) maken we op dat de kans op klachtenvrij worden van patiënten bovendien significant groter was, wanneer bij instroom de klacht korter aanwezig was en er geen psychosociale problemen waren.

Vervolgens is een drietal qua localisatie frequent (minimaal 10x) aangeboden klachten (schouder, elleboog en knie) gerelateerd aan de variabele 'klachtenvrij zijn na één jaar' (tabel 3.1.2.4.IV).

Tabel 3.1.2.4.IV Frequent (minimaal 10x) in beide groepen aangeboden klachten gerelateerd aan 'klachtenvrij zijn na één jaar'.

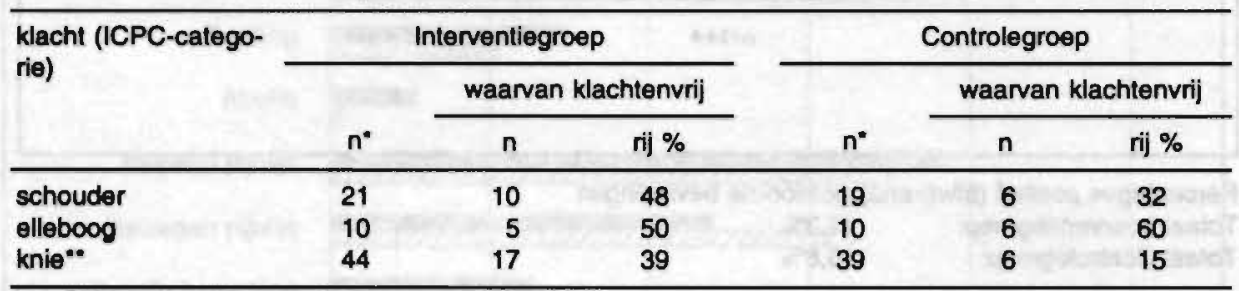

- Chi-kwadraattoets $p=0.93$

*- Chi-kwadraatloets $p=0.03$

Deze klachten waren in beide groepen in overeenkomstige aantallen $(p=0.93)$ aanwezig.

$\mathrm{Bij}$ knieklachten zien we in de interventiegroep na één jaar significant meer $(p=0.03)$ klachtenvrije patiënten. 
Tabel 3.1.2.4.V Mate waarin verwijzingen hebben plaatsgevonden voor de frequent (minimaal 10x) in beide groepen aangeboden klachten gerelateerd aan 'klachtenvrij zijn na één jaar'.

\begin{tabular}{|c|c|c|c|c|c|c|}
\hline \multirow{3}{*}{ 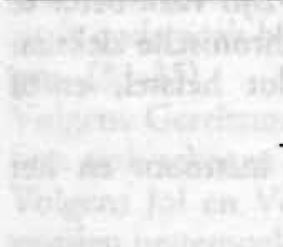 } & \multicolumn{3}{|c|}{$\begin{array}{c}\text { Interventiegroep } \\
\text { Frequent aangeboden klachten: } \\
\text { schouder, elleboog, knie } \\
n=75\end{array}$} & \multicolumn{3}{|c|}{$\begin{array}{l}\text { Controlegroep } \\
\text { Frequent aangeboden klachten: } \\
\text { schouder, elleboog, knie } \\
n=68\end{array}$} \\
\hline & \multirow{2}{*}{$\begin{array}{c}\text { totaal } \\
n\end{array}$} & \multicolumn{2}{|c|}{ klachtenvri] } & \multirow{2}{*}{$\begin{array}{c}\text { totaal } \\
n\end{array}$} & \multicolumn{2}{|c|}{ klachtenvrij } \\
\hline & & $n$ & nij \% & & $n$ & rij \% \\
\hline $\begin{array}{l}\text { venwezen } \\
\text { niet verwezen }\end{array}$ & $\begin{array}{l}26 \\
49\end{array}$ & $\begin{array}{l}13 \\
19\end{array}$ & $\begin{array}{l}50 \\
39\end{array}$ & $\begin{array}{l}47 \\
21\end{array}$ & $\begin{array}{r}10 \\
8\end{array}$ & $\begin{array}{l}21 \\
38\end{array}$ \\
\hline totaal & 75 & 32 & 43 & 68 & 18 & 26 \\
\hline
\end{tabular}

Tabel 3.1.2.4.VI Mate waarin verwezen patiënten met frequent aangeboden klachten al dan niet 'klachtenvrij zijn na één jaar'.

\begin{tabular}{lcc}
\hline & \multicolumn{2}{c}{ Venwezen patiènten } \\
& Interventiegroep* & Controlegroep* \\
\hline klachtenvrij & 13 & 10 \\
niet klachtenvrij & 13 & 37 \\
lotaal & 26 & 47 \\
\hline
\end{tabular}

Chi-kwadraattoets $p=0.02$

Bovendien is bij deze frequent aangeboden klachten voor de variabele 'klachtenvrij' nagegaan in welke mate verwijzingen hadden plaatsgevonden (tabel 3.1.2.4. V). Te zien is dat in de interventiegroep het percentage klachtenvrije verwezen patiënten $50 \%$ bedraagt, terwijl dat in de controlegroep slechts $21 \%$ is. Bij de niet verwezen patiënten zijn de percentages klachtenvrije patiënten in beide groepen vrijwel gelijk.

Uit tabel 3.1.2.4.VI blijkt eveneens dat patiënten met frequent aangeboden klachten na het gezamenlijk consult significant $(p=0.02)$ vaker klachtenvrij worden.

\section{DISCUSSIE}

De gegevens met betrekking tot gericht lichamelijk onderzoek lieten tijdens het instroommoment en tijdens de eindconsulten geen belangrijke verschillen tussen de groepen zien. Beide groepen patiënten toonden na één jaar vrijwel dezelfde vooruitgang. Wel was het aantal klachtenvrije patiënten in de interventiegroep tijdens het eindconsult hoger dan dat van de controlegroep. In beide groepen zien we na één jaar nog grote aantallen (65\% en $76 \%$ ) patiënten met klachten! De kans voor de patiënt na één jaar klachtenvrij te worden was groter wanneer 
op het moment dat de huisarts de patiënt selecteert voor het gezamenlijk consult de klacht nog niet lang aanwezig is en wanneer psychosociale problemen geen rol spelen.

Beide voorwaarden lijken verklaarbaar. Kortdurende klachten zijn vaak beter te behandelen omdat zij minder vaak het gevolg zullen zijn van chronische ziekten. Psychosociale problemen verhinderen waarschijnlijk een vlot herstel, en/of kunnen het ontstaan van klachten bevorderen. (31)

Een direct verband tussen geringe ernst van de klacht bij instroom en het klachtenvrij zijn na eén jaar werd echter niet vastgesteld.

Blijkbaar omvat de voor het gezamenlijk consult geselecteerde groep patiënten een groot aantal patiënten met chronische klachten welke moeilijk te verhelpen zijn, waarbij echter binnen én jaar vaak wel een duidelijke verbetering is vast te stellen.

Verwijzen lijkt na het gezamenlijk consult bij de drie meest frequent aangeboden klachtcategorieën, vergeleken met de gebruikelijke zorg, procentueel vaker te worden gevolgd door het klachtenvrij worden van de patiënten. Verwijzingen na het gezamenlijk consult lijken qua 'klachtenvrij' worden daardoor relatief effectiever. Hiervoor is geen duidelijke verklaring te geven.

\section{CONCLUSIES}

- $\mathrm{Na}$ het gezamenlijk consult verschilde de verbetering van de lichamelijke toestand van de patiënten na één jaar niet met die van patiënten behandeld door middel van de gebruikelijke zorg. Na het gezamenlijk consult waren er vergeleken met de gebruikelijke zorg wel significant meer klachtenvrije patiënten.

- Patiënten met bij instroom kortdurende klachten en geen of weinig psychosociale problemen hadden een grotere kans om na én jaar klachtenvrij te zijn.

\subsubsection{Co-morbiditelt}

\section{INLEIDING}

Klachten van patiënten, geselecteerd voor het gezamenlijk consult, zijn zoals reeds beschreven, vaak langdurig aanwezig. Vermoed wordr dat een belangrijk deel hiervan vaak multicausaal van aard is. In dit verband wordt ook gesproken over 'lichaamstaalklachten'. (37)

Vooral op het verloop van klachten waarbij vaak geen somatische oorzaak wordt gevonden, zou co-morbiditeit van invloed kunnen zijn, of zou daarbij een belangrijke rol kunnen spelen. (30-44)

Volgens van der Meer c.s. zijn er bij patiënten met chronisch klaaggedrag meer contactredenen, is er meer sprake van psychosociale problematiek en is er vaker sprake van depressie. (31)

Gussekloo c.s. vonden vaker somatisatie bij de groep chronische klagers. (45) Bovendien zouden vaak veel specialisten door deze patiënten worden geraadpleegd. Van der Meer c.s. concludeerden, dat huisartsen ongeveer $25 \%$ van de 
problemen in hun dagelijkse praktijk als psychosociaal beoordeelden, waarbij slechts enkele procenten werden ingevuld door de bekende psychiatrische syndromen. (31)

Ook Knottnerus en Portegijs c.s. wijzen op het gevaar van veelvuldig specialistisch onderzoek bij de somatiserende patiënt met mogelijk onnodige behandelingen. (33-35)

Volgens Gerritsma en Smal zou dit vooral gebeuren omdat specialisten het tot hun taak rekenen een aantal mogelijkheden uit te sluiten. (12)

Volgens Jol en Verhaak zouden $99 \%$ van alle klachten die als mede-psychisch worden bestempeld, en $95 \%$ van de klachten die als psychische- en sociale klacht door de patiënt worden gepresenteerd, door de huisarts zelf worden afgehandeld. (44)

Vaak wordt in onderzoek onvoldoende aandacht gegeven aan co-morbiditeit, hoewel volgens van der Velden co-morbiditeit bij klachten van het bewegingsapparaat vaak een rol speelt. (46)

Belleman waarschuwt dat bij patiënten met co-morbiditeit de verandering van de functionele toestand moeilijker is te meten. (26)

Volgens onderzoek van Bos neemt het geneesmiddelengebruik bij co-morbiditeit toe en treedt bij klachten van het bewegingsapparaat er in belangrijke mate comorbiditeit op na het $45 \mathrm{e}$ jaar. (47)

Meyboom-de Jong acht de kennis over de co-morbiditeit van de patiënten één van de essentiële aspecten van de huisartsgeneeskunde. (48)

Volgens Bensing was bij $86 \%$ van de patiënten met een hoge score op de 'general health questionnaire' de huisarts op de hoogte van het bestaan van psychosociale problematiek. (49)

Ook Van der Velden meende dat huisartsen in verreweg de meeste gevallen op de hoogte zijn van psychische problematiek bij hun patiënten. (50)

Wij veronderstellen dan ook dat de perceptie van de huisarts ten aanzien van comorbiditeit belangrijke informatie geeft.

Om na te gaan of deze variabele gelijk over beide groepen is verdeeld en om mogelijke effecten van co-morbiditeit (eventueel toegenomen aantal verrichtingen of verwijzingen) op het spoor te komen, zijn bij de instroom- en eindconsulten hieromtrent aan de patiënten en huisartsen vragen gesteld.

Co-morbiditeit is onderverdeeld en achtereenvolgens beschreven in de volgende drie onderwerpen: chronische aandoeningen, psychosociale aspecten en life-events. Aan de huisartsen werd tijdens de instroomconsulten gevraagd te registreren of de patiënt buiten de ingangsklacht een chronische- of langdurige ziekte of aandoening had. Bovendien werd gevraagd of naar zijn mening al dan niet belangrijke psychosociale aspecten bij de klacht een rol speelden.

Tijdens het eindconsult werd de huisartsen gevraagd of er zich naar hun mening belangrijke gebeurtenissen hadden voorgedaan welke een rol hebben gespeeld in het ziektebeeld/verloop. Bovendien zijn de patiënten tijdens de eindconsulten hieromtrent geënquêteerd. 


\section{Chronische aandoeningen}

Aan de huisartsen werd bij de instroomconsulten gevraagd naar aanwezige chronische of langdurige ziekte bij de patiënt.

De huisarts beantwoordde de vraag 'Heeft deze patiënt overigens een chronische of langdurige ziekte of aandoening buiten deze klacht?', met het antwoord 'ja' of 'nee' en maakte daarbij gebruik van de tot zijn beschikking staande voorkennis. Deze variabele werd eveneens gerelateerd aan 'verwijzingen'.

Tabel 3.1.3.I Chronische of langdurige ziekte volgens huisarts per groep bij instroomconsult gerelateerd aan de verwijzingen in één jaar.

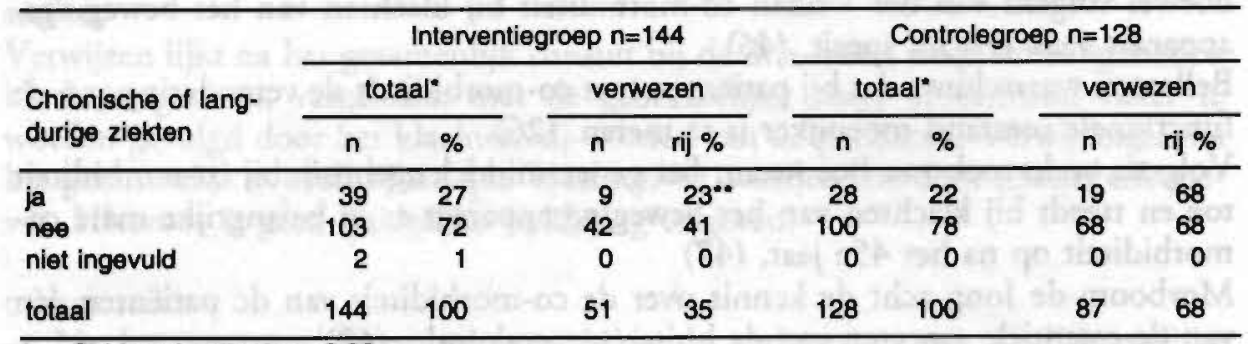

Chi-kwadraattoets $p=0.36$

-. Chi-kwadraattoets $p=0.07$

(getoetst met item 'niet ingevuld' als missing).

In tabel 3.1.3.I is in de interventiegroep het aantal patiënten met chronische aandoeningen iets groter in aantal.

Het aantal verwijzingen in de interventiegroep bij chronische ziekte was blijkens deze tabel echter wat lager $(p=0.07)$ dan bij niet chronisch zieken.

\section{Psychosociale aspecten}

$\mathrm{Bij}$ de instroomconsulten werd aan de huisartsen gevraagd of zij meenden dat psychosociale aspecten een rol speelden bij de klachten. De vraag: 'Zijn er belangrijke psychosociale aspecten die bij deze klacht een rol spelen?' kon met 'ja' of 'nee' worden gescoord.

Uit tabel 3.1.3.II blijkt dat de twee groepen met betrekking tot deze vraag niet belangrijk verschillen. 
Tabel 3.1.3.II Psychosociale aspecten die volgens huisarts een rol spelen bij de klacht per groep bij het instroomconsult, gerelateerd aan de verwijzingen in één jaar.

\begin{tabular}{|c|c|c|c|c|c|c|c|c|}
\hline \multirow[b]{3}{*}{$\begin{array}{l}\text { Belangrijke psycho- } \\
\text { sociale aspecten }\end{array}$} & \multicolumn{4}{|c|}{ Interventiegroep $n=144$} & \multicolumn{4}{|c|}{ Controlegroep $n=128$} \\
\hline & \multicolumn{2}{|c|}{ totaal" } & \multicolumn{2}{|c|}{ verwezen } & \multicolumn{2}{|c|}{ totaal" } & \multicolumn{2}{|c|}{ verwezen } \\
\hline & $n$ & $\%$ & n & rij \% & $n$ & $\%$ & n & rij \% \\
\hline ja & $\begin{array}{r}25 \\
119\end{array}$ & $\begin{array}{l}17 \\
83\end{array}$ & $\begin{array}{r}7 \\
44\end{array}$ & $\begin{array}{l}28 * * \\
37\end{array}$ & $\begin{array}{r}25 \\
103\end{array}$ & $\begin{array}{l}20 \\
80\end{array}$ & $\begin{array}{l}18 \\
69\end{array}$ & $\begin{array}{l}72 \\
67\end{array}$ \\
\hline totaal & 144 & 100 & 51 & 35 & 128 & 100 & 87 & 68 \\
\hline
\end{tabular}

Chi-kwadraattoets $p=0.74$

*. Chi-kwadraattoets $p=0.53$

De resultaten van de multivariate analyse geven voor deze variabele wel opvallende resultaten te zien. Er is een significant grotere kans voor 'klachtenvrij zijn na één jaar', wanneer er geen psychosociale problemen werden gescoord. (Zie bijlage 17). Bovendien werd in de controlegroep bij patiënten met psychosociale problemen vaker medicatie gegeven door de huisarts (OR 3.88, 95\% IC 1.20-12.5).

Eveneens valt in beide groepen op, dat de huisartsen significant meer patiënten verwezen naar de fysiotherapeut wanneer psychosociale aspecten aanwezig waren. (Bijlage 19).

\section{Life-events}

Aan patiënten en huisartsen werd onafhankelijk van elkaar bij het eindconsult gevraagd naar life-events, die naar hun oordeel gevolgen hadden gehad op het verloop van de klacht. De vragen konden worden beantwoord met de antwoorden: 'ja', 'twijfel', 'nee' of 'weet niet'.

Tabel 3.1.3.III Belangrijke gebeurtenissen die volgens patiënt en huisarts een rol zouden hebben gespeeld in het ziektebeloop per groep bij het eindconsult.

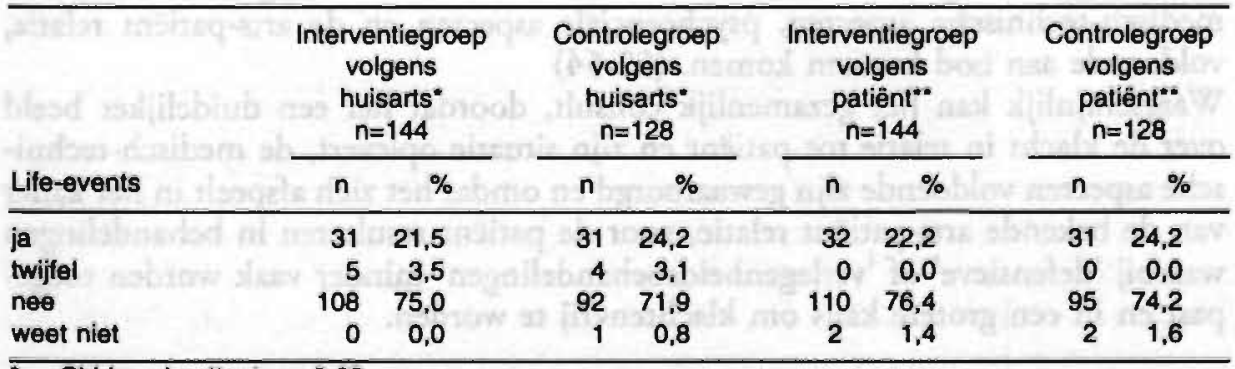

Chi-kwadraattoets $p=0.68$

-. Chi-kwadraattoets $p=0.80$

(getoetst met de items 'twijfel' en 'weet niet' als missing). 
In bovenstaande tabel zien we geen significante verschillen tussen interventie- en controlegroep en tussen de resultaten van huisartsen en patiënten.

$\mathrm{Bij}$ het relateren van life-events aan verwijzingen werden, evenals bij de multivariate analyse, geen opvallende verbanden gezien.

\section{DISCUSSIE}

Uit de gegevens blijkr dat de percentages chronische aandoeningen, psychosociale aspecten en life-events in beide groepen niet relevant verschilden en bij ongeveer $25 \%$ van de patiënten aanwezig waren. $\mathrm{Zij}$ zullen dientengevolge tussen de groepen voor de resultaten niet als verstorende variabele optreden. Conform eerdere onderzoeksresultaten schatten de huisartsen het aantal life-events gelijk aan dat van de patiënten. (48-50)

Te verwachten is dat hetzelfde zal gelden voor chronische ziekten en psychosociale aspecten.

Waar wij bij gebruikelijke zorg verwachtten dat patiënten met chronische ziekten, psychosociale aspecten ten aanzien van de klacht en life-events een grotere kans lopen verwezen te worden, lijkt voor chronische ziekten inderdaad een lichte trend te herkennen dat de kans op verwijzing in de interventiegroep kleiner dan gemiddeld is. Hierdoor is mogelijk op dit gebied belangrijke winst te behalen.

Vanuit de literatuur is bekend dat binnen het basisvaardighedenpakket van de huisarts belangrijke taken zijn aangegeven voor patiënten met chronische ziekten, psychosociale problemen en/of life-events. $(48,51)$

Uit de multivariate analyses dringt het idee zich op, dat de aanwezigheid van psychosociale problemen prognostisch een slecht teken is.

Ook Belleman beschreef dat bij patiënten met co-morbiditeit de functionele toestand minder verbeterde dan bij patiënten zonder co-morbiditeit. (26)

Patiënten met psychosociale problemen hadden een significant lagere kans om klachtenvrij te worden en kregen daarbij in de gebruikelijke zorg vaker medicatie voorgeschreven. Zowel na het gezamenlijk consult als in de gebruikelijke zorg werden zij frequenter verwezen naar de fysiotherapeut. Mogelijk moeten zowel medicatie als fysiotherapie hierbij worden gezien als 'verlegenheidsbehandelingen'. Het lijkt goed mogelijk dat in het gezamenlijk consult de drie dimensies waaraan Dimatteo, Bensing en Smits de kwaliteit van consulten hebben gemeten, te weten medisch-technische aspecten, psychosociale aspecten en de arts-patiënt relatie, voldoende aan bod kunnen komen. (52-54)

Waarschijnlijk kan het gezamenlijk consult, doordat het een duidelijker beeld over de klacht in relatie tot patiënt en zijn situatie oplevert, de medisch-technische aspecten voldoende zijn gewaarborgd en omdat het zich afspeelt in het kader van de bekende arts-patiënt relatie, voor de patiënt resulteren in behandelingen waarbij 'defensieve' of 'verlegenheidsbehandelingen' minder vaak worden toegepast en in een grotere kans om klachtenvrij te worden. 
- Co-morbiditeit kwam bij $25 \%$ van de voor het gezamenlijk consult geselecteerde patiënten voor. Bij patiënten met co-morbiditeit lijkt na het gezamenlijk consult de kans op verwijzing iets af te nemen.

- Bij patiënten met psychosociale problemen, geselecteerd voor het gezamenlijk consult, was de kans na één jaar klachtenvrij te worden significant verlaagd. Bij gebruikelijke zorg was bij aanwezigheid van psychosociale problemen de kans op medicatie op voorschrift van de huisarts significant verhoogd.

- Bij patiënten met psychosociale aspecten, geselecteerd voor het gezamenlijk consult, was de kans op fysiotherapie op voorschrift van de huisarts, eveneens verhoogd.

\subsubsection{Ervaren algemene gezondheidstoestand}

\section{INLEIDING}

Wanneer de algemene gezondheidstoestand door de patiënt als minder goed wordt ervaren zal dit naar verwachting gevolgen hebben voor de verrichtingen en de verwijzingen. Bovendien is te verwachten dat klachten, door de huisartsen geïndiceerd voor het gezamenlijk consult, invloed uitoefenen op de algemene gezondheidstoestand en omgekeerd. Om deze redenen hebben we getracht inzichr te krijgen in de ervaren gezondheidstoestand van de patiënten door het gebruik van een vragenlijst ervaren gezondheid, conform de C.B.S.-enquête-lijst (55) en door middel van een korte V.O.E.G. (Vragen Over Ervaren Gezondheid)lijst. (56)

De gezondheidstoestand van de patiënten is bij de instroom- en eindconsulten gescoord overeenkomstig de daarvoor gebruikte lijst met 5-puntsschaal met betrekking tot de gezondheidsbeleving van de CBS-enquête van 1988. (55)

De korte VOEG-lijst werd eveneens tijdens instroom- en eindconsult gescoord en betreft een gevalideerde lijst met dertien vragen, welke handelen over verschillende functies (zie bijlagen $1 A+B$ en $7 A+B$ ). Per positief gescoorde vraag werd én punt gerekend. Ook met betrekking tot dit onderwerp is primair nagegaan, of er bij de instroom verschillen tussen beide groepen waren en vervolgens of tijdens het verloop van het onderzoek veranderingen zijn opgetreden. 


\subsubsection{Lijst ervaren gezondheld}

Tabel 3.1.4.1.I Beoordeling van eigen gezondheid volgens patiënt per groep tijdens instroom- en eindconsult.

\begin{tabular}{|c|c|c|c|c|}
\hline \multirow[b]{2}{*}{$\begin{array}{l}\text { Beoordeling eigen } \\
\text { gezondheid }\end{array}$} & \multicolumn{2}{|c|}{ Instroom } & \multicolumn{2}{|c|}{ Eindconsult } \\
\hline & $\begin{array}{c}\text { Interventiegroep } \\
\qquad \begin{array}{c}n=144^{\circ} \\
\%\end{array}\end{array}$ & $\begin{array}{c}\text { Controlegroep } \\
\begin{array}{c}n=128^{*-} \\
\%\end{array}\end{array}$ & $\begin{array}{c}\begin{array}{c}\text { Interventiegroep } \\
n=144^{*} \\
\%\end{array} \\
{ }^{*}\end{array}$ & $\begin{array}{c}\text { Controlegroep } \\
\begin{array}{c}n=128^{* *} \\
\%\end{array}\end{array}$ \\
\hline zeer goed & 16,4 & 14,8 & 14,3 & 9,2 \\
\hline good & 57,0 & 60,3 & 57,8 & 61,2 \\
\hline matig & 23,0 & 21,6 & 24,7 & 28,2 \\
\hline slecht & 3,0 & 2,0 & 3,2 & 1,4 \\
\hline zeer slecht & 0,6 & 1,3 & 0 & 0 \\
\hline
\end{tabular}

Wilcoxon signed-rank test $\mathrm{p}=0.32$

-. Wilcoxon signed-rank test $p=0.19$

Chi-kwadraattoets Instroom Interventie-/Controlegroe $p=0.90$

Chi-kwadraattoets Eindconsult Interventie-/Controlegroep $p=0.83$

(de items 'zeer goed' en 'goed' samengevoegd en de items 'matig', 'slecht' en 'zeer slecht':df=1).

Uit tabel 3.1.4.1.I blijkt dat de beoordeling van de eigen gezondheid tussen beide groepen overeenkwam, terwijl tussen instroom- en eindconsult geen relevant verschil was op te merken.

In vergelijking met de landelijke CBS-gegevens (tabel 3.1.4.1.II) scoorden de patiënten van het effectiviteitsonderzoek duidelijk lager.

TABEL 3.1.4.1.II Gezondheidsbeleving, resultaten van CBS-enquête 1990.

\begin{tabular}{lrr}
\hline & \multicolumn{2}{c}{$n=8223$} \\
\cline { 2 - 3 } Gezondheidsbeleving & $n$ & \multicolumn{1}{c}{$\%$} \\
\hline zeer goed & 2444 & 30 \\
goed & 4407 & 53,5 \\
gaat wel (matig) & 833 & 10,1 \\
soms goed/soms slecht & 394 & 4,7 \\
slecht & 145 & 1,7 \\
\hline
\end{tabular}

\subsubsection{V.O.E.G.-Lijat}

Volgens de tabellen van de VOEG-lijsten is gedurende het jaar wel een verbetering opgetreden.

De gemiddelde VOEG-waarden daalden voor de interventie- respectievelijk controlegroep van 4.46 (S.D. 2.99) tot 4.05 (S.D. 3.16) en van 4.52 (S.D. 2.96) tot 4.38 (S.D. 3.16). 
Er waren geen significante verschillen tussen de groepen tijdens instroom- en controlemoment. ( $T$-toets instroom $\mathrm{p}=0.87$, eindconsult $\mathrm{p}=0.39$ )

De vOEG-scores laten voor beide groepen bij de eindconsulten een lichte verbetering zien. De 'delta'-analyses van de VOEG-scores laten eveneens geen significante verschillen zien. $(\mathrm{p}=0.43)$

Om na te gaan op welke wijze de wijzigingen van de gemiddelden en standaarddeviaties tot stand zijn gekomen, zijn scores ten aanzien van spreidingen en waarderingen van de patiëntenscores getoetst door middel van de Wilcoxon-toets, hetgeen eveneens geen significant $(p=0.88)$ verschil aantoonde.

\section{DISCUSSIE}

De algemene gezondheidstoestand van de patiënten van beide groepen verschilde tijdens instroom- en eindconsulten niet significant. Voor beide groepen was na één jaar volgens de 'gezondheidsbeleving 5-puntsschaal' geen en volgens de vOEGscores een lichte verbetering van de algemeen ervaren gezondheidstoestand opgetreden.

De algemene gezondheidstoestand van de patiënten was gemiddeld slechter dan die van de algemene bevolking. Dit lijkt begrijpelijk waar de CBS-studie (55) een steekproef uit de bevolking betreft, welke qua leeftijdsverdeling weliswaar enigszins afwijkt van de onderzoekspopulatie. De patiënten die deelnamen aan de effectiviteitsstudie hadden daarentegen vaak langdurige klachten waar dikwijls pathologie en co-morbiditeit aan gerelateerd was, en balanceerden op het grensvlak van eerste en tweede lijn.

Het gezamenlijk consult en de gebruikelijke zorg lijken echter geen belangrijke verbetering van de door de patiënten subjectief ervaren algemene gezondheidstoestand op te leveren, hoewel de subjectief ervaren en objectief gemeten gezondheidstoestand direct gerelateerd aan de klacht wel verbeterde. Dit zou kunnen betekenen dat veranderingen wat betreft de aan de klacht gerelateerde gezondheidsbeleving geen belangrijke gevolgen opleveren voor de algemene ervaren gezondheidstoestand. Deze bevinding is mogelijk te verklaren doordat de klachten van het bewegingsapparaat slechts door én item in de vOEG-lijst worden gescoord, hetgeen bij de zelfbeoordeling van de algemene gezondheidstoestand waarschijnlijk relatief weinig gewicht in de schaal zal leggen.

\section{CONCLUSIES}

De gepercipieerde algemene gezondheidsbeleving, bij patiënten geselecteerd voor het gezamenlijk consult met klachten van het bewegingsapparaat, verschilde voor en na het gezamenlijk consult en voor en na de gebruikelijke zorg én tussen beide groepen, niet duidelijk.

\subsubsection{Ervaren functioneren}

\section{INLEIDING}

De mate waarin mensen actief zijn in werk en vrije tijd geeft mede een indruk over hun gezondheidstoestand en kan consequenties hebben voor en resultaat zijn van de te leveren of geleverde gezondheidszorg. 
Om deze reden zijn enerzijds aan de patiënten vragen gesteld over hun activiteiten in verband met werk en vrije tijd en is anderzijds gebruik gemaakt van de S.I.P. (Sickness Impact Profile) -lijst, die ontworpen is om de invloed van ziekten op het dagelijks functioneren te meten. (57-62)

De S.I.P.-enquête kan worden toegepast voor een zeer brede doelgroep. De invloed van ziekten en geneeskundige onderzoeken en behandelingen op de kwaliteit van leven kan met de S.I.P.-enquête bij diverse groepen mensen worden gemeten.

Om de invloed van ziekre op het dagelijks functioneren te meten (zie ook paragraaf 2.5.4.) is, zoals beschreven in paragraaf 2.5.4., bovendien gebruik gemaakt van een zevental categorieën van de S.I.P.-lijst. (57-62)

De fysieke dimensies, bestaande uit de drie categorieën 'lichaamsverzorging en beweging', 'mobiliteit' en 'lopen', werden in hun totaliteit opgenomen in de enquête. De resultaten van de fysieke dimensies werden zowel afzonderlijk als categorie en gezamenlijk geanalyseerd. De categorieën 'slapen/rusten', 'emotioneel gedrag', 'huishouden' en 'recreatie en vrije tijd' werden eveneens volledig in de enquête opgenomen.

Dit was niet het geval voor de categorieën 'sociale interacties' en 'werk', welke niet werden opgenomen omdat reeds een meer gedetailleerde vragenlijst was toegevoegd (zie 'werk en activiteiten'). De categorieën 'intellectueel functioneren en alertheid', 'communicatie' en 'eten' werden voor het onderzoek minder relevant geacht en om deze reden eveneens niet opgenomen in de enquête.

$\mathrm{Bij}$ de analyses is gebruik gemaakt van de waarden zoals die aan de verschillende items als afspiegeling van het relatieve belang worden toegekend. $(58,59)$

De S.I.P.-enquêtes werden zowel ten tijde van het instroom- en het eindconsult ingevuld (zie bijlagen $1 A+B$ en $7 A+B$ ). De verschillende resultaten van de interventie- en controlegroep zijn getoetst door middel van een $T$-toets.

Om een indruk te krijgen over de mogelijkheden tot verrichten van werk- en vrijetijdse activiteiten werden aan de patiënten van beide groepen hieromtrent bij het instroom- en eindconsult vragen gesteld.

RESULTATEN

\subsubsection{Werken en activitelten}

De resultaten van de instroomconsulten laten geen belangrijke verschillen zien tussen beide groepen (bijlage 14).

Ook bij analyse van de resultaten met betrekking tot de activiteirenbeperking ten tijde van het eindconsult, blijken tussen de groepen geen significante verschillen aanwezig (eveneens bijlage 14).

$\mathrm{Bij}$ vergelijking van de eindconsultmetingen met de instroommetingen zien we eveneens geen opvallende verschillen tussen de groepen. 


\subsubsection{S.I.P. (SIckness Impact Profile)}

$\mathrm{Bij}$ de instroommetingen bedroegen de gemiddelde gewogen totaal S.I.P.-scores voor de interventie- en controlegroep respectievelijk 270.2 en 260.1 met een S.D. van 346.2 en 302.7.

De eindmetingen resulteerden in respectievelijk een gemiddelde waarde van 185.3 met een S.D. 272.6 en 186.3 met een S.D. 281.4.

Zowel tijdens de instroom- als tijdens de eindconsulten zagen we geen significante verschillen tussen beide groepen (instroom T-toets p.waarde 0.79 , eindconsult $\mathrm{T}$-toets p.waarde 0.82 ). Voor beide groepen waren de verschillen tussen instroom- en eindmeting wel significant (respectievelijke p.waarde van 0.02 en 0.04).

De 'delta'-analyses van de S.I.P.-scores (betreffende de verschillen tussen de scores bij instroom- en eindmeting) lieten tussen beide groepen eveneens geen significant verschil zien $(\mathrm{p}=0.41)$.

Voor de 'fysieke dimensies'-categorieën samen waren de resultaten bij de instroom voor interventie- en controlegroep achtereenvolgens 98,9 en 93,2 voor de gemiddelden met S.D. van 190,0 en 161,1 hetgeen niet significant verschillend is ( $T$-toets $\mathrm{p}=0.78$ ), terwijl bij de eindconsulten de scores hiervoor achtereenvolgens 64,1 en 62,8 met een S.D. van 135,0 en 152,9 bedroegen, hetgeen eveneens een niet significant verschil betekende ( $T$-toets $p=0.94$ ).

Voor de afzonderlijke 'fysieke dimensie'-categorieën ('lichaamsverzorging en beweging', 'mobiliteit' en 'lopen') waren de resultaten van de groepen niet verschillend en identiek aan die van de drie categorieën gezamenlijk.

\section{DISCUSSIE}

Patiënten die in aanmerking kwamen voor het gezamenlijk consult waren als gevolg van de ingangsklacht voor een belangrijk deel beperkt in hun activiteiten ten aanzien van werken, (ongeveer $40-45 \%$ ) en vrije tijd (ongeveer $70 \%$ ). Tussen beide groepen werd geen relevant verschil bij instroom- en eindmeting vastgesteld.

De resultaten van de S.I.P.-enquêtes van beide groepen verschilden onderling niet significant tijdens instroom- en eindconsult.

Tijdens het onderzoeksjaar was in beide groepen vrijwel dezelfde significante verbetering opgetreden. Dit betekent dat het subjectief beleven gerelateerd aan de klachten in beide groepen bij aanvraag vrijwel gelijk was en na éen jaar in gelijke mate was verbeterd.

Deze bevindingen komen overeen met de onder paragraaf 3.1.2. beschreven resultaten van de klachtgegevens, waar eveneens behoudens de aantallen klachtenvrije patiënten tijdens het verloop van éen jaar tussen beide groepen geen significante verschillen werden vastgesteld. Het gezamenlijk consult lijkt vergeleken met het consult in de gebruikelijke zorg na één jaar geen specifieke meerwaarde met betrekking tot de subjectief ervaren gezondheidstoestand op te leveren. 
Patiënten geselecteerd voor het gezamenlijk consult en het consult in de gebruikelijke zorg ervoeren zowel bij de instroom- als de eindmeting vaak en op overeenkomstige wijze beperkingen in hun activiteiten met betrekking tot werk en vrije tijd. De door middel van S.I.P.-enquêtes gemeten verbetering van de subjectieve gezondheidstoestand bij patiënten die deelnamen aan het gezamenlijk consult week na én jaar niet af van die van patiënten die op de gebruikelijke wijze werden behandeld.

\subsubsection{Verwachtingen en ervaringen van patiönt en huisarte blj de hulpverlening}

\section{INLEIDING}

Omdat uit eerder onderzoek bekend is, dat de wens van de patiënt tot verwijzing een belangrijke rol speelt in het verwijzingsproces, was het van belang na te gaan in welke mate de wens om verwezen te worden bestond bij de patiënten die deelnamen aan het onderzoek, alsmede de perceptie hieromtrent bij de huisartsen. (63-66)

Onderzoek naar de mate van (on)tevredenheid van patiënten over de zorg van de huisarts is van belang bij de toepassing van een nieuwe werkwijze. (65-69)

Om deze redenen hebben we zowel bij huisarts als bij patiënt gevraagd naar de wenselijkheid van verwijzing bij de instroom en werden de patiënten vragen gesteld over satisfactie en gekregen aandacht met betrekking tot het instroomconsult en het gezamenlijk consult. Aan alle patiënten werd bij het instroomconsult gevraagd naar de mate waarin zij aandacht kregen en tevreden waren over de genoten behandeling. Patiënten die deelnamen aan het gezamenlijk consult werden bovendien naar hun mening gevraagd over deze werkwijze.

De patiënten beantwoordden na het gezamenlijk consult door middel van een 5-puntsschaal de vraag in hoeverre zij deze wijze van samenwerken voor zichzelf van belang achtren en of zij al dan niet liever direct zouden zijn verwezen.

Over de tevredenheid van de patiënten ten aanzien van de wijze van behandeling (therapie) werden eveneens vragen gesteld. De gegevens omtrent therapie konden echter niet worden gebruikt, omdat bij controle bleek, dat patiënten vragen ten aanzien van therapie, verwarden met 'fysiotherapie'. Om deze reden zijn de vragen niet opgenomen in de analyse.

De verwachtingen en belevingen ten aanzien van satisfactie en aandacht van beide groepen bij instroom- en gezamenlijk consult werden eveneens onderling vergeleken en bovendien gerelateerd aan de verwijzingen naar specialisten in de onderzoeksperiode. Bovendien behoorde de variabele 'wens verwijzing' tot de onafhankelijke variabelen welke met de onderscheiden afhankelijke variabelen door middel van de multipele logistische regressie analyses werden geanalyseerd. (Zie bijlagen 19 en 21). 


\subsubsection{Wenselijkheid van verwijzing}

Uit de tabellen 3.1.6.1.I en 3.1.6.1.II blijkt, dat de groepen wat betreft de wens tot verwijzingen en hun verwachtingen nauwelijks van elkaar verschillen, terwijl daarbij tevens blijkt dat deze patiënten met betrekking tot hun klacht meestal niet (ongeveer $60-70 \%$ ) verwachtten of wensten dat de huisarts zelf zou blijven behandelen.

Tabel 3.1.6.1.I Verwachtingen volgens patiënt per groep ten aanzien van behandeling na het instroomconsult. Vraag aan patiënt na instroomconsult: Wat had u verwacht dat uw huisarts zou doen? (meer antwoorden aan te kruisen).

\begin{tabular}{lcccccc}
\hline & \multicolumn{2}{c}{ Interventiegroep* $n=144$} & & \multicolumn{2}{c}{ Controlegroep ${ }^{*} n=28$} \\
\cline { 2 - 3 } \cline { 6 - 7 } & $n$ & $\%$ & & $n$ & $\%$ \\
\hline zelf afhandelen & 50 & & 34,7 & & 52 & 40,6 \\
venwijzen near specialist & 70 & & 48,6 & & 58 & 45,3 \\
verwijzen naar therapeut & 48 & & 33,3 & & 48 & 37,5 \\
niet over nagedacht & 16 & & 11,1 & & 7 & 5,5 \\
weet niet & 10 & & 6,9 & & 10 & 7,8 \\
anders & 8 & & 5,6 & & 4 & 3,1 \\
\hline
\end{tabular}

- Chi-kwadraattoets $p=0.56$

(getoetst zonder item 'anders' en de items 'niet over nagedacht' en 'weet niet' samengevoegd: $\mathrm{df}=3$ )

Tabel 3.1.6.1.II Verwachtingen volgens patiënt per groep ten aanzien van behandeling na het instroomconsult. Vraag aan patiënt na instroomconsult: Wat wilde u zelf dat uw huisarts zou doen? (meer antwoorden aan te kruisen).

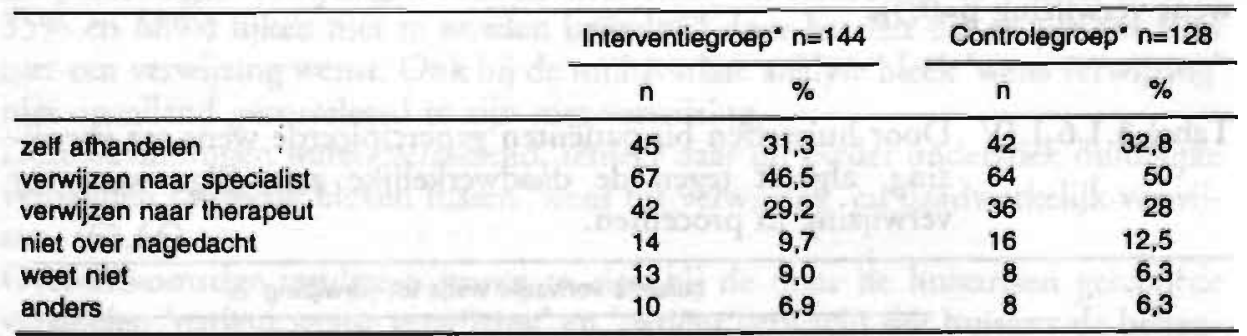

- Chi-kwadraattoets $\mathrm{p}=0.98$

(getoetst zonder item 'anders' en de items 'niet over nagedacht' en 'weet niel' samengevoegd: $d f=3$ ) 
Tabel 3.1.6.1.III Verwachting volgens de huisartsen per groep ten aanzien van behandeling na het instroomconsult. Vraag aan huisarts na instroomconsult: Wat denkt $u$ dat de patiënt van $u$ verwachtte?

\begin{tabular}{lcc}
\hline & $\begin{array}{c}\text { Interventiegroep } n=144 \\
\%\end{array}$ & $\begin{array}{c}\text { Controlegroep* } n=128 \\
\%\end{array}$ \\
\hline zelf afhandelen & 34,0 & 31,3 \\
verwijzen naar specialist & 39,6 & 38,3 \\
verwijzen naar therapeut & 5,6 & 7,8 \\
pationt had geen verwachting & 19,4 & 18,8 \\
anders & 1,4 & 3,8 \\
\hline
\end{tabular}

- Chi-kwadraattoets $p=0.87$ (getoetst zonder item 'anders')

We zien dat huisartsen de verwachtingen van patiënten omtrent verwijzing naar specialist en/of fysiotherapeut respectievelijk enigszins en fors onderschatten (tabellen 3.1.6.1.I en 3.1.6.1.III). Dit was niet het geval voor de aantallen patiënten waarbij zij meenden dat 'zelfstandig afhandelen' verwacht werd. Hierbij stemden de verwachtingen van huisarts en patiënt grotendeels overeen.

Uit tabel 3.1.6.1.IV blijkt voorts dat huisartsen bij bijna de helft van de patiënten waarbij zij een wens tot verwijzing aanwezig achtten, deze wens abusievelijk aanwezig achtten en gelijktijdig bij een groter aantal patiënten de wens tot verwijzing over het hoofd zagen.

In de tabel 3.1.6.1.V zien we na follow-up in de controlegroep bij de categorie patiënten, bij wie een wens tot verwijzing naar de specialist aanwezig was, een groot aantal verwijzingen $(70,3 \%)$ in tegenstelling tot de interventiegroep, waar dit slechts bij $40,3 \%$ van de patiënten het geval was.

De aantallen verwijzingen in de gevallen waarin de patiënt een verwijzing wenste verschillen echter niet significant van de aantallen verwijzingen in de gevallen waarin geen verwijzing werd gewenst (interventiegroep verwezen patiënten zonder wens verwijzing $\mathrm{p}=0.3$ ).

Tabel 3.1.6.1.IV Door huisartsen bij patiënten gepercipieerde wens tot verwijzing, afgezet tegen de daadwerkelijke aanwezige wens tot verwijzing in procenten.

\begin{tabular}{|c|c|c|c|c|c|c|c|c|}
\hline \multirow{3}{*}{ patient wenst verwijzing } & \multicolumn{8}{|c|}{ huisarts verwacht wens tot verwijzing } \\
\hline & \multicolumn{4}{|c|}{ Interventiegroep $n=144$} & \multicolumn{4}{|c|}{ Controlegroep $n=128$} \\
\hline & $\begin{array}{l}\text { ja } \\
\%\end{array}$ & $\begin{array}{c}\text { nee } \\
\%\end{array}$ & $\begin{array}{c}\text { niet } \\
\text { ingevuld }\end{array}$ & $\begin{array}{c}\text { totaal } \\
\%\end{array}$ & $\begin{array}{l}\text { ja } \\
\%\end{array}$ & $\begin{array}{c}\text { nee } \\
\%\end{array}$ & $\begin{array}{c}\text { niet } \\
\text { ingevuld }\end{array}$ & $\begin{array}{c}\text { totaal } \\
\%\end{array}$ \\
\hline ja & 22 & 24 & & 46 & 22 & 28 & & 50 \\
\hline $\begin{array}{l}\text { nee } \\
\text { nlet ingevuld }\end{array}$ & $\begin{array}{r}17 \\
0\end{array}$ & $\begin{array}{r}35 \\
0\end{array}$ & 2 & $\begin{array}{r}52 \\
2\end{array}$ & $\begin{array}{r}16 \\
0\end{array}$ & $\begin{array}{r}32 \\
0\end{array}$ & 2 & $\begin{array}{r}48 \\
2\end{array}$ \\
\hline Iotaal & 39 & 59 & 2 & 100 & 38 & 60 & 2 & 100 \\
\hline
\end{tabular}


Uit de multivariate analyse (bijlage 19) blijkt dat wanneer de patiënt geen verwijzing naar specialist wenst, dit vooral bij gebruikelijke zorg (controlegroep: OR $0.39,95 \%$, CI $0.17-0.90$ ) significant gerelateerd is aan verwijzingen van de huisartsen voor fysiotherapie gedurende het jaar van onderzoek.

Uit bijlage 21 is op te maken dat bij patiënten zonder een wens voor verwijzing naar de specialist door de huisartsen vaker röntgenonderzoek werd aangevraagd.

Tabel 3.1.6.1.V Daadwerkelijke verwijzingen tijdens het onderzoeksjaar, gerelateerd aan de wens tot verwijzing bij de instroom van patiënten in beide groepen.

\begin{tabular}{|c|c|c|c|c|c|c|c|c|}
\hline \multirow{3}{*}{$\begin{array}{l}\text { patient wenst } \\
\text { venwijzing }\end{array}$} & \multicolumn{4}{|c|}{ Interventiegroep } & \multicolumn{4}{|c|}{ Controlegroep } \\
\hline & \multicolumn{2}{|c|}{ totaal" } & \multicolumn{2}{|c|}{$\begin{array}{c}\text { verwijzingen in } \\
\text { én jaar }\end{array}$} & \multicolumn{2}{|c|}{ totaal" } & \multicolumn{2}{|c|}{$\begin{array}{c}\text { verwijzingen in } \\
\text { Gén jaar }\end{array}$} \\
\hline & $n$ & $\%$ & $n$ & rij \% & $n$ & $\%$ & $n$ & rij $\%$ \\
\hline $\begin{array}{l}\text { Ja } \\
\text { nee }\end{array}$ & $\begin{array}{l}67 \\
77\end{array}$ & $\begin{array}{l}46,5 \\
53,5\end{array}$ & $\begin{array}{l}27 \\
23\end{array}$ & $\begin{array}{l}40,3 \\
30,7\end{array}$ & $\begin{array}{l}64 \\
64\end{array}$ & $\begin{array}{l}50 \\
50\end{array}$ & $\begin{array}{l}45 \\
40\end{array}$ & $\begin{array}{l}70,3 \\
64,5\end{array}$ \\
\hline
\end{tabular}

- Chi-kwadraaltoets $p=0.64$

* Chi-kwadraattoets $p=0.30$

\section{DISCUSSIE}

De wens tot verwijzing scoorde, conform de verwachtingen en de resultaten van eerder onderzoek, hoog in de populatie die in anmerking komt voor het gezamenlijk consult. (63)

De huisarts onderschatte in zijn totaliteit de wens tot verwijzing van de patiënt enigszins en achtte deze wens vaak aanwezig bij de verkeerde patiënt. Ditzelfde gold voor de belevingen bij de klacht.

De percentages verwijzingen voor de interventie- en controlegroep (respectievelijk $35 \%$ en $68 \%$ ) lijken niet te worden beïnvloed door het feit dat de patiënt al of niet een verwijzing wenst. Ook bij de multivariate analyse bleek 'wens verwijzing' niet opvallend gecorreleerd te zijn met verwijzing.

Deze bevindingen waren verrassend, temeer daar uit eerder onderzoek duidelijke verbanden aanwezig bleken tussen 'wens tot verwijzing' en daadwerkelijk verwijzen. $(63,66)$

Overeenkomstige resultaten waren te zien bij de door de huisartsen gescoorde variabelen 'patiënt wenst verwijzing' en 'patiënt verwacht dat huisarts de behandeling zelf zal afhandelen' (tabellen van deze variabelen zijn niet opgenomen). Mogelijk zijn deze resultaten te verklaren door de bevinding dat huisartsen weliswaar vaak de indruk hebben dat er een wens tot verwijzing is, welke meeweegt in hun beslissingen, maar dat zij dit dikwijls ten onrechte vermoedden, terwijl ook vaak het omgekeerde het geval was.

Indien er geen wens tot verwijzing was, werd zowel na het gezamenlijk consult als in de gebruikelijke zorg vaker röntgenonderzoek aangevraagd en vaker 
verwezen voor fysiotherapie. Als verklaring kan wellicht gelden dat patiënten die geen verwijzing wensen, toch de drang van de huisartsen om iets te doen prikkellen, waardoor bij hen vaker röntgenonderzoek en fysiotherapie wordt toegepast.

\section{CONCLUSIES}

De bij patiënten hoog scorende verwachting 'wens verwijzing naar specialist' werd in zijn totaliteit door de huisartsen enigszins onderschat en daarbij vaak niet bij de juiste patiënten aanwezig geacht.

Wanneer patiënten een verwijzing naar de specialist wensten, was er vergeleken met de overige patiënten uit dezelfde groep, geen significant hogere kans op verwijzing. Wel werden patiënten die bij het instroomconsult niet aankruisten dat zij verwezen wilden worden, vaker door de huisartsen naar de fysiotherapeut verwezen en werd door de huisartsen bij deze patiënten vaker röntgenonderzoek aangevraagd.

\subsubsection{Aandacht en satisfactie}

\section{RESULTATEN}

Uit tabel 3.1.6.2.I blijkt dat na het instroomconsult tussen de groepen geen verschil is op te merken over de mate waarin de patiënten meenden dat zij aandacht kregen van de huisarts.

Meer dan $90 \%$ van de patiënten was van mening dat zij voldoende tor ruim voldoende aandacht kregen.

Vergelijkbare resultaten zien we bij tabel 3.1.6.2.II ten anzien van de aandacht volgens de patiënt gekregen tijdens het gezamenlijk consult.

Tabel 3.1.6.2.I Mate waarin patiënten per groep naar hun mening aandacht hadden gekregen tijdens het instroomconsult. Vraag aan patiënt na instroomconsult: 'Heeft U voldoende aandacht gekregen?'.

\begin{tabular}{lcccccc}
\hline & \multicolumn{2}{c}{ Interventiegroep* $n=144$} & & \multicolumn{2}{c}{ Controlegroep* $n=128$} \\
\cline { 2 - 3 } \cline { 6 - 7 } & $n$ & & $\%$ & & $n$ & $\%$ \\
\hline nuim voldoende & 69 & 47,9 & & 59 & 46,1 \\
voldoende & 69 & 47,9 & & 62 & 48,4 \\
matig & 6 & 4,2 & & 6 & 4,7 \\
weinig & 0 & & & & 1 & 0,8 \\
geen & 0 & & & & 0 & 0 \\
\hline
\end{tabular}

- Chi-kwadraattoets $p=0.83$

(getoetst met de items 'ruim voldoende' en 'voldoende' samengevoegd, evenals de items 'matig', 'weinig' en 'geen'). 
Tabel 3.1.6.2.II Mate waarin patiënten van de interventiegroep naar hun mening aandacht hadden gekregen tijdens het gezamenlijk consult. Vraag aan patiënt na het gezamenlijk consult: 'Heeft U voldoende aandacht gekregen?.

\begin{tabular}{lcc}
\hline & \multicolumn{2}{c}{ Interventiegroep $n=144$} \\
\cline { 2 - 3 } & $\mathbf{n}$ & $\%$ \\
\hline zeer veel & 51 & 35,4 \\
veel & 79 & 54,9 \\
matig & 13 & 9,0 \\
weinig & 1 & 0,7 \\
geen & 0 & 0 \\
\hline
\end{tabular}

Tabel 3.1.6.2.III Mate waarin patiënten van de interventiegroep naar hun mening het gezamenlijk consult als werkwijze voor zichzelf van belang achtten. Vraag aan patiënt na het gezamenlijk consult: 'Ik vind deze manier van samenwerken voor mij van belang'.

\begin{tabular}{lrr}
\hline & \multicolumn{2}{c}{ Interventiegroep $n=144$} \\
\cline { 2 - 3 } & $n$ & $\%$ \\
\hline volledig mee eens & 90 & 62,5 \\
mee eens & 47 & 32,6 \\
niet mee eens/niet mee oneens & 4 & 2,8 \\
mee oneens & 2 & 1,4 \\
volledig mee oneens & 1 & 0,7 \\
\hline
\end{tabular}

Tabel 3.1.6.2.IV Mate waarin patiënten van de interventiegroep na het gezamenlijk consult van mening zijn dat zij liever direct zouden zijn verwezen, gerelateerd aan het aantal verwijzingen na één jaar. Vraag aan patiënt na het gezamenlijk consult: 'Ik zou liever direct zijn verwezen naar de specialist'.

\begin{tabular}{lrrrr}
\hline & \multicolumn{4}{c}{ Interventiegroep $n=144$} \\
\cline { 2 - 5 } & $n$ & $\%$ & $n$ & $\begin{array}{c}\text { verwezen } \\
\text { rij \% }\end{array}$ \\
\hline volledig mee eens & 12 & 8,3 & 7 & 58,3 \\
mee eens & 15 & 10,4 & 3 & 20,0 \\
niet mee eens/niet mee oneens & 54 & 37,5 & 19 & 35,2 \\
mee oneens & 38 & 26,4 & 15 & 39,5 \\
volledig mee oneens & 22 & 15,3 & 6 & 27,3 \\
niet ingevuld & 3 & 2,1 & 1 & 33,3 \\
\hline
\end{tabular}


Hoewel uit de scores van tabel 3.1.6.2.III blijkt dat patiënten het gezamenlijk consult overwegend $(95,1 \%)$ voor zichzelf van belang achtten, zien we in tabel 3.1.6.2.IV dat $18,7 \%$ toch liever direct zou zijn verwezen.

Wanneer patiënten bij deze laatste vraag 'volledig mee eens' scoorden, zien we binnen tén jaar verhoudingsgewijs een hoog verwijspercentage $(58,3 \%)$.

Bij het relateren van de variabelen 'aandacht' en 'satisfactie' aan 'verwijzingen' zagen we in beide groepen geen afwijkende verwijscijfers.

\section{DISCUSSIE}

Aandacht, verkregen bij consulten in de gebruikelijke zorg en het gezamenlijk consult, satisfactie over het gezamenlijk consult en daarbij ervaren zinvolheid, scoorden hoog. Deze resultaten komen overeen met eerder onderzoek naar satisfactie. (64-69)

Het kleine verschil ten aanzien van 'aandacht' tussen de scores na het consult in de gebruikelijke zorg en na het gezamenlijk consult is mogelijk het gevolg van de verschillen in de formulering van de antwoorden op de vraag naar verkregen aandacht. $\mathrm{Na}$ het instroomconsult werd de vraag: 'Heeft $\mathrm{U}$ voldoende aandacht gekregen?' gescoord met de antwoorden 'ruim voldoende', 'voldoende', 'matig' 'weinig' en 'geen', terwijl dit na het gezamenlijk consult door middel van de antwoorden 'zeer veel', 'veel', 'matig', 'weinig' en 'geen' gebeurde.

Voorts lijkr discrepantie te bestaan tussen de resultaten van de patiëntenoordelen 'Ik vond deze manier van samenwerken voor mij van belang' en 'Ik zou liever direct zijn verwezen naar de specialist', omdat de eerste vraag door meer dan 95\% van de patiënten werd beantwoord met 'volledig mee eens' en 'mee eens', terwijl volgens de antwoorden van de tweede vraag $18 \%$ van de patiënten liever direct zou worden verwezen.

$\mathrm{Bij}$ de beantwoording van de tweede vraag speelde een wens tot verwijzing en de omgekeerde betekenis van de vragenlijst wellicht een rol, waardoor een schijnbare tegenstrijdigheid in de resultaten mogelijk is te verklaren.

In grote lijnen lijkt de conclusie gerechtvaardigd, dat patiënten tevreden waren over het gezamenlijk consult en de werkwijze positief waardeerden, al werd een kleine minderheid van de patiënten, waarvan er achteraf relatief veel werden verwezen, liever direct verwezen.

\section{CONCLUSIES}

Gekregen aandacht, satisfactie en beoordeling van de zinvolheid scoorden bij patiënten na het gezamenlijk consult hoog. Gekregen aandacht scoorde in de gebruikelijke zorg eveneens hoog.

Wanneer patiënten na een gezamenlijk consult liever direct zouden zijn verwezen, lijkt de kans op verwijzing binnen één jaar verhoogd. 


\subsection{Proces- en zorgvariabelen (verrichtingen en verwijzingen)}

\section{INLEIDING}

Om inzicht te krijgen in de inhoud en de mate van doelmatigheid van de geleverde zorg is het van belang geïnformeerd te worden over de verrichtingen welke tijdens die zorg plaats vonden. Naast vaststelling van de aantallen verrichtingen is kennis over het verband met klacht-, patiëntkenmerken en/of huisartsmotieven gewenst.

Lamberts beschreef in verband met defensief handelen de motieven van de arts bij het aanvullend onderzoek, terwijl Wielink de kosteneffectiviteit als aandachtspunt beschreef. (70-71)

De in deze paragraaf beschreven groep variabelen, met behulp waarvan informatie werd verkregen over de inhoud van de geleverde zorg, is onderverdeeld in variabelen welke het hulpverleningsproces en de als gevolg van dit proces geleverde zorg betreffen, en gerubriceerd in de volgende categorieën:

- Consulten en verwijzingen

- Diagnostische verrichtingen

- laboratorium onderzoek

- röntgenologisch onderzoek

- Therapeutische verrichtingen

- medicatie

- fysiotherapie, Cesar, Mensendieck

- hulpmiddelen (supplementen, corsetten, bandages)

- operaties

De registratie van de variabelen gebeurde als volgt:

- Consulten en verwijzingen

Bezoeken van patiënten vanwege de ingangsklacht aan huisarts en/of specialist, visites van huisartsen, verwijzingen (uitsluitend nieuwe verwijzingen) door huisartsen naar specialisten.

- Laboratorium-onderzoek

Alle laboratorium-onderzoeken gerelateerd aan de ingangsklacht aangevraagd of verricht door huisartsen en/of specialisten.

$\mathrm{Bij}$ de multipele logistische regressie analyses werd op basis van de registratiegegevens vastgesteld, of al dan niet laboratoriumonderzoek was verricht. Dit werd dus behandeld als een dichotome variabele.

- Röntgen-onderzoek

Identiek aan het laboratoriumonderzoek.

- Medicatie

Elk afzonderlijk voorschrift van huisarts en/of specialist werd geregistreerd.

Dit gold eveneens voor vervolgmedicatie-voorschriften.

- Fysiotherapie, Cesartherapie, Mensendiecktherapie

De verwijzingen en eventuele herhalingen werden per 12 behandelsessies als dichotome variabelen geregistreerd. 


\section{- Hulpmiddelen}

De afzonderlijke hulpmiddelen werden geregistreerd.

- Operaties

Elke operatieve behandeling werd geregistreerd.

Bovenstaande gegevens worden allen als effectvariabelen beschouwd.

De verrichtingen zijn ingedeeld in diagnostische (laboratorium- en röntgenonderzoek) en therapeutische (medicatie, injecties en fysiotherapie) verrichtingen. Operatieve behandelingen worden apart beschreven.

Verwijzingen zijn gedeeltelijk reeds beschreven gerelateerd aan patiëntvariabelen.

Over de verrichtingen en verwijzingen gerelateerd en voorafgaand aan de ingangsklacht werden aan patiënt en huisarts tijdens het instroomconsult en het gezamenlijk consult vragen gesteld. Vervolgens werden de gegevens door de huisartsen gedurende één jaar in de vervolglijsten geregistreerd. (Bijlagen $1 \mathrm{~A}+$ $1 \mathrm{~B}, 2 \mathrm{~A}+2 \mathrm{~B}, 3,4,5)$.

De gegevens van de vervolglijsten werden vóór het eindconsult gecontroleerd door de huisartsen. De projectleiding controleerde eveneens nog alle vervolglijsten met de hulp van de huisartsen, de huisartsregistratiesystemen, de eventueel gevoerde correspondentie, de poliklinische statussen en de gegevens van de financiële administratie van het Academisch Ziekenhuis Maastricht.

Achtereenvolgens worden de behandeling voorafgaand aan de instroom, de consulten, verwijzingen en verrichtingen sinds het moment van instroom, alsmede een kosten-baten analyse beschreven.

De diagnostische en therapeutische verrichtingen zijn in de bivariate analyses eveneens gerelateerd aan de vraag of de patiënt tijdens de onderzoeksperiode naar een specialist is verwezen.

Bovendien is bij de analyses van de proces- en zorgvariabelen zoals beschreven, gebruik gemaakt van multivariate analyses.

\subsubsection{Behandeling voorafgaand aan de Instroom}

INLEIDING

Omdat de klachten van patiënten die door huisartsen voor een gezamenlijk consult worden aangeboden vaak een lange voorgeschiedenis hebben (zie ook paragraaf 3.1.2.1. Klachtkenmerken) diende ook de aan de ingangsklacht gerelateerde voorafgaande behandeling qua verrichtingen en verwijzingen in beeld te worden gebracht.

Het aantal verrichtingen tijdens de aan het instroommoment voorafgaande behandelingsperiode zou consequenties kunnen hebben voor het aantal verrichtingen na het moment van instroom. Daarom was het van belang te weten of er hieromtrent tijdens het instroommoment tussen de interventie- en controlegroep verschillen bestonden.

Vanwege bovenstaande redenen werd tijdens het instroommoment aan de patiënten een vraag gesteld over het recidiverend voorkomen van de klacht en aan de 
huisartsen een aantal vragen over aan het instroommoment voorafgaande mogelijke diagnostische- of therapeutische verrichtingen en andere verwijzingen naar aanleiding van de ingangsklacht.

\section{RESULTATEN}

Uit de tabellen 3.2.1.I en II zien we dat beide groepen qua voorgeschiedenis, verrichtingen en verwijzingen op het instroommoment niet significant van elkaar verschilden.

Tabel 3.2.1.I Mate waarin patiënten per groep voor het instroomconsult eerder identieke klachten hebben gehad.

\begin{tabular}{|c|c|c|c|c|}
\hline \multirow{2}{*}{ 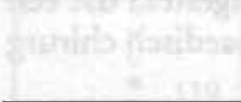 } & \multicolumn{2}{|c|}{ Interventiegroep $n=144$} & \multicolumn{2}{|c|}{ Controlegroep $p^{*} n=128$} \\
\hline & $n$ & $\%$ & $n$ & $\%$ \\
\hline $\begin{array}{l}\text { ja } \\
\text { nee }\end{array}$ & $\begin{array}{l}55 \\
89\end{array}$ & $\begin{array}{l}38,2 \\
61,8\end{array}$ & $\begin{array}{l}40 \\
88\end{array}$ & $\begin{array}{l}31,2 \\
68,8\end{array}$ \\
\hline
\end{tabular}

Chi-kwadraattoets $p=0.28$

Tabel 3.2.1.II Vraag aan huisarts tijdens instroomconsult bij beide groepen: 'Welke verrichtingen zijn voorheen voor deze klacht uitgevoerd?'

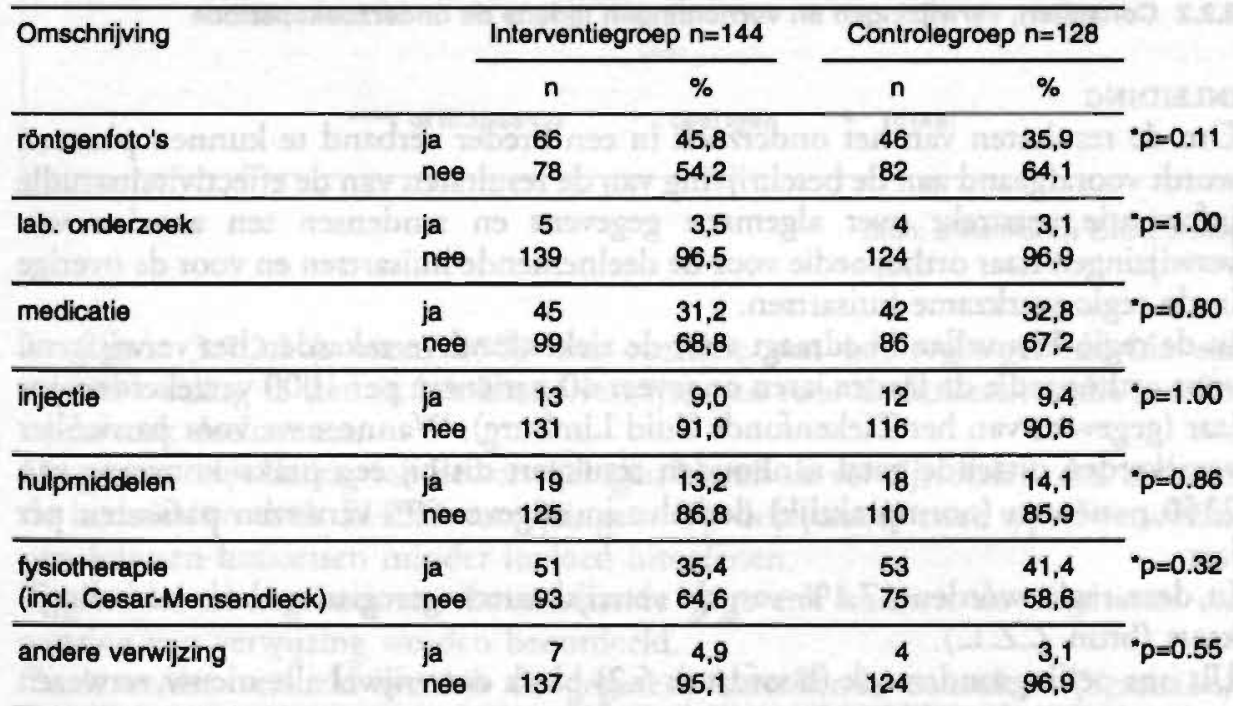

Fisher's Exact Test

\section{DISCUSSIE}

De metingen laten tussen beide groepen geen duidelijke verschillen zien. Gezien de resultaten is te verwachten dat de behandeling voorafgaand aan de instroom 
geen verstorende invloed uit zal oefenen op het verdere verloop in beide groepen. Bij ongeveer $1 / 3$ van de patiënten van beide groepen was er sprake van een recidiverende klacht.

De patiënten bleken in verband met de klacht, qua onderzoek en behandeling op het gebied van röntgenfoto's, medicatie en fysiotherapie, al vaak een voorgeschiedenis te hebben. Ondanks de frequente toepassing van de beschreven diagnostische en therapeutische verrichtingen was blijkbaar onvoldoende verbetering opgetreden, en wenste de huisarts daarom een gezamenlijk consult. Onvoldoende verbetering van klachten ondanks gebruik van deze diagnostische- en therapeutische faciliteiten is conform de resultaten van eerder onderzoek. $(70,72-78)$

Dit past bij de verwachtingen en de eerdere bevindingen ten aanzien van klachtduur en klachtbelevingen, zoals eerder beschreven in paragraaf 3.1.2. en komt overeen met de resultaten van eerder onderzoek, waarbij werd vastgesteld dat een belangrijk deel van de klachten, waarvoor het advies van de orthopaedisch chirurg werd gevraagd, langdurig bestond. $(79,80)$.

\section{CONCLUSIES}

De klachten waarvoor patiënten voor het gezamenlijk consult werden aangeboden zijn bij ongeveer $1 / 3$ van de patiënten recidiverend van aard, waarvoor op het moment van instroom, blijkbaar zonder voldoende resultaat, al vaak diagnostische en therapeutische handelingen zijn verricht.

\subsubsection{Consulten, verwijzingen en verrichtingen tijdens de onderzoeksperiode}

\section{INLEIDING}

Om de resultaten van het onderzoek in een breder verband te kunnen plaatsen wordt voorafgaand aan de beschrijving van de resultaten van de effectiviteitsstudie informatie verstrekt over algemene gegevens en tendensen ten aanzien van verwijzingen naar orthopaedie voor de deelnemende huisartsen en voor de overige in de regio werkzame huisartsen.

In de regio Heuvelland bedraagt voor de ziekenfondsverzekerden het verwijsgetal voor orthopaedie de laatste jaren ongeveer 40 patiënten per 1000 verzekerden per jaar (gegevens van het Ziekenfonds Zuid Limburg). Wanneer we voor particulier verzekerden ditzelfde getal aanhouden resulteert dit bij een praktijkomvang van 2350 patiënten (normpraktijk) derhalve in ongeveer 95 verwezen patiënten per jaar.

In deze regio worden $17,1 \%$ van de verwijskaarten geregistreerd als herhalingskaart (bron Z.Z.L.).

Uit ons peilingsonderzoek (hoofdstuk 6.2) bleek dat vrijwel alle nieuw verwezen patiënten van de polikliniek orthopaedie door de huisartsen zijn verwezen, ook al komt een aantal van hen via de EHBO binnen.

Per huisartspraktijk wordt jaarlijks gemiddeld ongeveer $70 \%$ van het totale aantal verwezen patiënten door huisartsen nieuw verwezen $(=$ ongeveer 65 patiënten per jaar). 
De op het regio-gemiddelde geïndexeerde verwijsgetallen van de aan het onderzoek deelnemende huisartsen wat betreft de verwijzingen orthopaedie en het totaal aantal verwijzingen zien we in figuur 3.2.2.I. (Bron Ziekenfonds ZuidLimburg).

Figuur 3.2.2.I

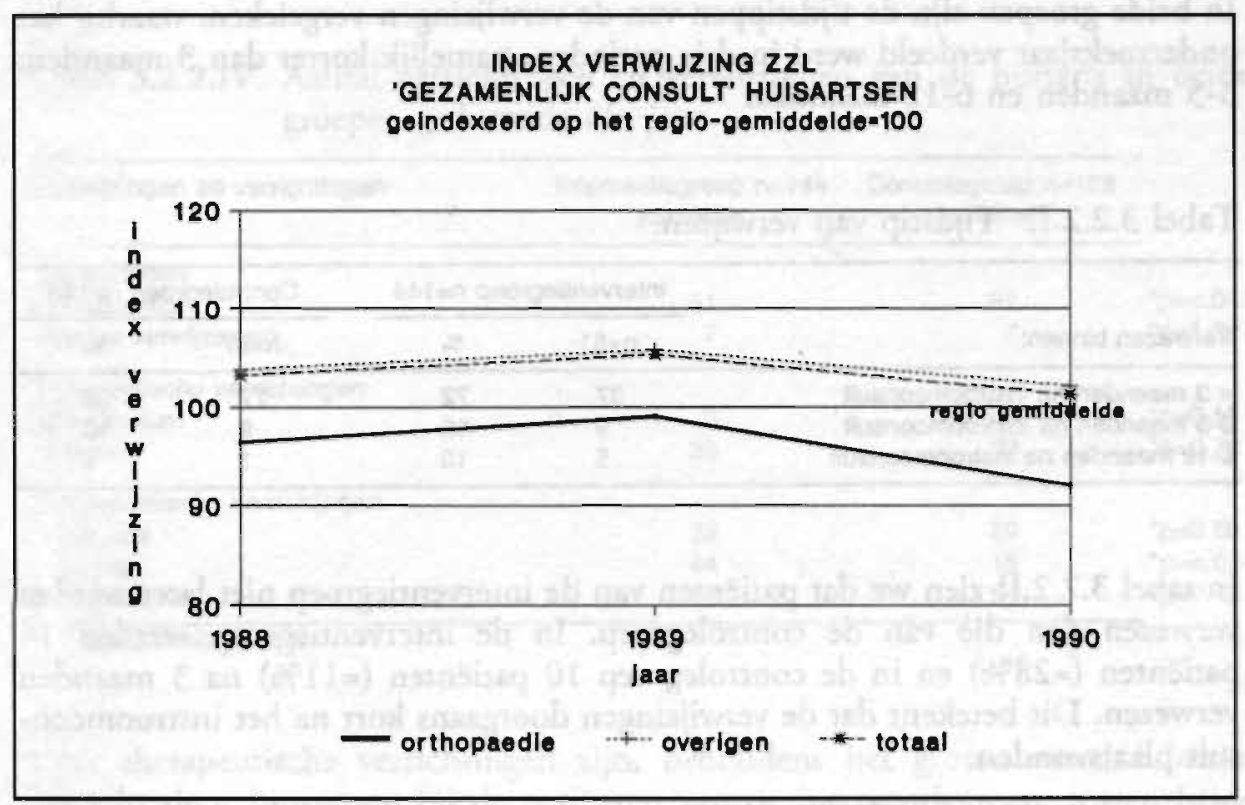

Bron: Ziekenfonds Zuid-Limburg

In figuur 3.2.2.I is vanaf 1989 ten opzichte van het regio-gemiddelde een relatieve daling te zien in het aantal verwijzingen voor de huisartsen, die aan het onderzoek deelnamen.

De procentuele daling van de verwijzingen betreft de verwijstotalen, dus inclusief de herhaal- en deels EHBO-verwijzingen. Op deze laatste twee typen verwijzingen kunnen huisartsen minder invloed uitoefenen.

Tegen de achtergrond van bovenstaande gegevens kunnen de resultaten ten aanzien van verwijzing worden beoordeeld.

Zoals eerder vermeld werden de gegevens betreffende consulten (bezoeken), verwijzingen en verrichtingen van beide groepen patiënten (al dan niet gezamenlijk consult) gedurende een jaar geregistreerd, gekoppeld aan het gegeven of huisarts dan wel de orthopaedisch chirurg verantwoordelijk was voor de verrichting.

Eerst worden de resultaten met betrekking tot het tijdstip van verwijzing voor patiënten van beide groepen beschreven, om na te gaan of het gezamenlijk 
consult mogelijk leidt tot te late of uitgestelde verwijzingen. Vervolgd wordt met de verwijzingen en verrichtingen van de interventie- en controlegroepen gerelateerd aan huisartsen en specialisten.

\section{RESULTATEN}

Tijdstip van verwijzing

In beide groepen zijn de tijdstippen van de verwijzingen vergeleken, waarbij het onderzoeksjaar verdeeld werd in drie perioden, namelijk korter dan 3 maanden; 3-5 maanden en 6-12 maanden.

Tabel 3.2.2.II Tijdstip van verwijzen.

\begin{tabular}{|c|c|c|c|c|}
\hline \multirow[b]{2}{*}{ Venwezen binnen: } & \multicolumn{2}{|c|}{ Interventiegroep $n=144$} & \multicolumn{2}{|c|}{ Controlegroep $n=128$} \\
\hline & $n=51$ & $\%$ & $n=87$ & $\%$ \\
\hline $\begin{array}{l}\text { < } 3 \text { maanden na instroomconsult } \\
\text { 3-5 maanden na instroomconsult } \\
\text { 6-12 maanden na instroomconsult }\end{array}$ & $\begin{array}{r}37 \\
9 \\
5\end{array}$ & $\begin{array}{l}72 \\
18 \\
10\end{array}$ & $\begin{array}{r}77 \\
9 \\
1\end{array}$ & $\begin{array}{r}89 \\
10 \\
1\end{array}$ \\
\hline
\end{tabular}

In tabel 3.2.2.II zien we dat patiënten van de interventiegroep niet later werden verwezen dan die van de controlegroep. In de interventiegroep werden 14 patiënten $(=28 \%)$ en in de controlegroep 10 pariënten $(=11 \%)$ na 3 maanden verwezen. Dit betekent dat de verwijzingen doorgaans kort na het instroomconsult plaatsvonden.

\section{Consulten, verrichtingen en verwijzingen}

Zoals reeds eerder beschreven vonden in de interventiegroep, vergeleken met de controlegroep, opvallend minder verwijzingen plaats.

Het aantal bezoeken aan de huisarts was in de controlegroep vrijwel gelijk aan dat van de interventiegroep (interventiegroep gemiddeld 1.00 en voor de controlegroep gemiddeld $0.97, T$-toets $p=0.85$ ). Het aantal bezoeken aan de orthopaed was in de controlegroep gemiddeld duidelijk hoger (respectievelijk 1.24 en 2.15 bezoeken, $\mathrm{p}=<.01$ ). (Zie tabel 3.2.2.III). Voor de verwezen patiënten bedroeg het gemiddelde bezoekaantal aan de polikliniek orthopaedie voor de interventiegroep 3.49 en voor de controlegroep 3.16. ( $p=0.05)$

Laboratoriumonderzoek is door de huisartsen in beide groepen weinig aangevraagd, terwijl het aantal röntgenfoto's tussen beide groepen niet belangrijk verschilde (zie tabel 3.2.2.IV). 
Tabel 3.2.2.III Gemiddeld aantal bezoeken aan huisarts en orthopaed per patiënt per groep.

\begin{tabular}{|c|c|c|}
\hline Gemiddeld aantal bezoeken & Interventiegroep $n=144$ & Controlegroep $n=128$ \\
\hline aan huisarts & $\begin{array}{l}1.00 \\
1.24\end{array}$ & $\begin{array}{l}0.97 \\
2.15\end{array}$ \\
\hline
\end{tabular}

- T-toets

Tabel 3.2.2.IV Aantal verrichtingen en verwijzingen van de huisarts in beide groepen gedurende eén jaar.

\begin{tabular}{|c|c|c|}
\hline Verwijzingen en verrichtingen & $\begin{array}{c}\text { Interventiegroep } n=144 \\
\text { aantallen }\end{array}$ & $\begin{array}{c}\text { Controlegroep } n=128 \\
\text { aantallen }\end{array}$ \\
\hline $\begin{array}{l}\text { Venwijzingen } \\
\text { orthopaedie } \\
\text { overige verwijzingen }\end{array}$ & $\begin{array}{r}51 \\
7\end{array}$ & $\begin{array}{r}87 \\
7\end{array}$ \\
\hline $\begin{array}{l}\text { Diagnostische verrichtingen } \\
\text { laboratorium } \\
\text { rőntgen }\end{array}$ & $\begin{array}{r}2 \\
35\end{array}$ & $\begin{array}{r}6 \\
29\end{array}$ \\
\hline $\begin{array}{l}\text { Therapeutische verrichtingen } \\
\text { medicatie } \\
\text { injecties } \\
\text { fysiotherapie }\end{array}$ & $\begin{array}{l}32 \\
44 \\
62\end{array}$ & $\begin{array}{l}29 \\
15 \\
54\end{array}$ \\
\hline
\end{tabular}

- Mann-Whitney test

Qua therapeutische verrichtingen zijn, behoudens het groter aantal injecties verricht door huisartsen bij de patiënten van de interventiegroep, tussen beide groepen geen belangrijke verschillen op te merken.

Uit de multipele regressie analyse blijkt eveneens een significant verschil tussen beide groepen voor verwijzingen naar de orthopaedisch chirurg. (Zie bijlage 22) In beide groepen zien we dat door de huisartsen vaker röntgenonderzoek werd aangevraagd, wanneer patiënten geen verwijzing naar de specialist wensten. (Zie bijlage 21). Bij patiënten behorend tot de interventiegroep werd bovendien vaker röntgenonderzoek door de huisartsen aangevraagd, wanneer de ingangsklacht lang bestond (OR 4.02, 95\% CI 1.36-11.9).

De huisartsen schreven vaker medicatie voor bij ernstige klachten (zie bijlage 18) Aan patiënten van de controlegroep werd bovendien door de huisartsen vaker medicatie voorgeschreven wanneer zij meenden dat er psychosociale problemen aanwezig waren (OR $3.88,95 \%$ CI 1.20-12.5).

Injecties, door de huisartsen vaker toegepast bij patiënten van de interventiegroep, werden vooral gegeven wanneer huisartsen 'vaardigheden ontwikkelen' als motief voor het gezamenlijk consult noteerden, en minder vaak bij het motief 'kennisvermeerdering'. (Zie bijlage 20).

Fysiotherapie werd door de huisartsen en ook door huisartsen en orthopaedisch chirurgen tezamen, in de beide groepen vaker voorgeschreven wanneer de huisarts 
psychosociale problemen aanwezig achtte en hij als motief voor het gezamenlijk consult 'patiënt ongerust' noteerde (bijlagen 19+32).

De huisartsen verwezen bovendien vaker naar de fysiotherapeut als er geen wens voor verwijzing naar de specialist was.

Tabel 3.2.2.V Aantal verrichtingen door de orthopaedische chirurg in beide totale groepen gedurende één jaar.

\begin{tabular}{|c|c|c|}
\hline Verrichtingen & $\begin{array}{c}\text { Interventiegroep } n=144 \\
\text { aantallen }\end{array}$ & $\begin{array}{c}\text { Controlegroep } n=128 \\
\text { aantallen }\end{array}$ \\
\hline $\begin{array}{l}\text { Diagnostische verrichtingen } \\
\text { laboratorium } \\
\text { róntgen }\end{array}$ & $\begin{array}{l}21 \\
44\end{array}$ & $\begin{array}{l}37 \\
91\end{array}$ \\
\hline $\begin{array}{l}\text { Therapeutische verrichtingen } \\
\text { medicatie } \\
\text { injecties } \\
\text { fysiotherapie } \\
\text { operatie }\end{array}$ & $\begin{array}{r}3 \\
5 \\
10 \\
25\end{array}$ & $\begin{array}{r}9 \\
39 \\
39 \\
23\end{array}$ \\
\hline
\end{tabular}

Mann-Whitney test

Tabel 3.2.2.V laat belangrijke verschillen zien tussen beide groepen. Voor de categorieën laboratorium- en röntgenonderzoek, injecties en fysiotherapie is er een significant hogere score voor de controlegroep.

Wat daarnaast opvalt is het aantal operaties dat in beide groepen vrijwel gelijk was, hoewel het aantal verwijzingen in de controlegroep bijna het dubbele bedroeg van dat in de interventiegroep.

De multipele logistische regressie analyse laat zien dat in de controlegroep de orthopaedisch chirurgen patiënten significant vaker behandelden door middel van injecties wanneer huisartsen 'vaardigheden ontwikkelen' als motief voor het gezamenlijk consult notecrden. (OR 2.78, 95\% CI 1.06-7.31).

Tabel 3.2.2.VI Aantal verrichtingen door huisarts en orthopaedisch chirurg tezamen in beide groepen gedurende één jaar bij de verwezen patiënten.

\begin{tabular}{|c|c|c|}
\hline & $\begin{array}{l}\text { Interventiegroep } n=144 \\
\text { aantallen }\end{array}$ & $\begin{array}{c}\text { Controlegroep } n=128 \\
\text { aantallen }\end{array}$ \\
\hline laboratorium & 23 & 43 \\
\hline röntgen & 79 & 120 \\
\hline medicatie & 35 & 38 \\
\hline injecties & 49 & 54 \\
\hline tysiotherapie & 72 & 93 \\
\hline operatie & 25 & 23 \\
\hline
\end{tabular}

Mann-Whitney test 
In tabel 3.2.2.VI zien we behoudens de diagnostische verrichtingen en de aantallen verrichtingen fysiotherapie, geen belangrijke verschillen tussen beide groepen voor de aantallen verrichtingen van huisartsen en orthopaedisch chirurgen tezamen.

Uit de multipele lineaire regressie analyses blijkt bovendien dat de huisartsen en orthopaedisch chirurgen tezamen vaker röntgenonderzoek aanvroegen bij langer bestaande klachten $(\mathrm{p}=0.01)$, ter voorkoming van somatische fixatie (interventiegroep $\mathrm{p}=0.05$ ) en wanneer de huisartsen meenden dat de klachten al eerder aanwezig waren geweest (controlegroep $p=0.04$ ). De huisartsen en orthopaedisch chirurgen behandelden vaker door middel van medicatie wanneer de klachten door de patiënten bij de instroom ernstiger werden ingeschat $(p=<.01)$ en verwezen vaker voor fysiotherapie wanneer de huisarts psychosociale aspecten aanwezig achtte $(p=0.04)$ en de patiënt ongerust vond $(p=<.01)$. (Zie bijlage 32$)$.

\section{DISCUSSIE}

De resultaten met betrekking tot consulten, verwijzingen en verrichtingen laten overeenkomsten en verschillen zien tussen interventie- en controlegroep.

Wanneer patiënten van beide groepen werden verwezen, gebeurde dit meestal kort na het instroomconsult. Het gezamenlijk consult lijkt dientengevolge niet te worden gevolgd door een belangrijk aantal 'uitgestelde' verwijzingen en heeft waarschijnlijk als gevolg dat 'noodzakelijke' verwijzingen plaats vinden. Voornamelijk de aantallen consulten bij de orthopaedisch chirurg, de laboratorium- en röntgenverrichtingen verschilden opmerkelijk tussen interventie- en controlegroep.

De huisartsen en orthopaedisch chirurgen lieten bij patiënten van de controlegroep ongeveer $30 \%$ meer röntgenfoto's maken en ongeveer $50 \%$ meer laboratoriumonderzoek uitvoeren.

De verschillen per verwezen patiënt waren gemiddeld minder groot.

Een 'overmaat' aan laboratoriumdiagnostiek zou volgens Sandler en Eisenberg onder meer in de hand worden gewerkt door onvoldoende kennis, defensief handelen en door de neiging onzekerheid te vertalen in diagnostische actie. $(81,82)$

Kluyt et al tonen op basis van de Nationale Studie aan dat de Nederlandse huisarts zorgvuldig gebruik maakt van de beeldvormende diagnostiek. (75)

Toch blijkt uit diverse onderzoeken dat het bewegingsapparaat voor huisartsen het grootste indicatiegebied is voor röntgenonderzoek en deze onderzoekmethodiek (bijvoorbeeld bij lage rugklachten) vaak een verwaarloosbaar effect oplevert voor het vaststellen van relevante pathologische bevindingen. Sturmans en Mulder wezen er al op dat de voorspellende waarde van een positieve uitslag van een test met een hoge sensitiviteit en specificiteit bij een lage prior kans, toch erg gering is. (83)

Door bovenstaande bevindingen en resultaten uit eerder onderzoek, lijkt het vastgestelde geringer aantal diagnostische verrichtingen na het gezamenlijk consult een gunstig resultaat. $(70,72-78,82-89)$ 
Ook lijkt het geringer aantal fysiotherapiebehandelingen een positief resultaat, omdat uit onderzoek blijkt dat hierbij eveneens een duidelijke indicatiestelling en een herkenbaar resultaat vaak lijkt te ontbreken. $(90,91)$

Dat huisartsen na het gezamenlijk consult relatief meer diagnostische verrichtingen aanvragen zou, conform de resultaten van het onderzoek van Dopheide en van der Zee, samenhangen met het geringer aantal verwijzingen. (92)

De na het gezamenlijk consult vastgestelde verschuiving van de therapeutische verrichtingen houdt in dat in de gebruikelijke zorg een aantal therapeutische verrichtingen (injecties, fysiotherapie) door specialisten wordt uitgevoerd, terwijl dit na het gezamenlijk consult door huisartsen wordt gedaan. Dit komt overeen met de mening van Groenewegen, die substitutie van zorg vooral voor een aantal therapeutische verrichtingen haalbaar acht. (93)

De redenen van het geringer aantal diagnostische en de verschuiving van een aantal therapeutische verrichtingen van orthopaedisch chirurg naar huisarts lijken voor een deel op te maken uit de verbanden van de verrichtingen met de onafhankelijke variabelen.

Uit de resultaten bleek immers vooral:

- Het röntgenonderzoek werd door huisartsen en orthopaedisch chirurgen in de controlegroep bij uitstek aangevraagd bij patiënten met langdurige en/of recidiverende klachten. In de interventiegroep gebeurde dit vooral bij langdurig bestaande klachten en ter voorkoming van somatische fixatie.

- Medicatie in beide groepen patiënten werd vooral bij ernstige klachten voorgeschreven.

- Het aantal injecties verricht door huisartsen was in de interventiegroep significant hoger, waarschijnlijk omdat deze behandelwijze bij uitstek tijdens het gezamenlijk consult werd aangeleerd. Uit de analyses bleek bovendien dat behandeling door middel van injecties vaak samenging met 'vaardigheden ontwikkelen' als motief van de huisarts voor het gezamenlijk consult.

- In beide groepen is door de huisartsen en ook door de huisartsen en orthopaedisch chirurgen tezamen vooral naar de fysiotherapeut verwezen bij psychosociale factoren en bij verdenking van ongerust zijn.

Dientengevolge lijkt duidelijk dat huisartsen, enerzijds na het gezamenlijk consult minder diagnostische verrichtingen nodig hebben bij patiënten met langdurig bestaande klachten en met psychosociale factoren, en anderzijds zij voor een aantal klachten waarvoor patiënten na het gezamenlijk consult relatief vaker bij hen onder behandeling blijven (schouder-, elleboog-, polsklachten), concrete therapeutische behandelingen (injecties) voorhanden hebben die zij tijdens het gezamenlijk consult toepassen.

Orthopaeden laten eveneens, en in grotere aantallen, vaak diagnostisch onderzoek en specifieke therapeutische verrichtingen in de gebruikelijke zorg uitvoeren bij de eerder beschreven ongeruste patiënten met vaak psychosociale problemen en met langdurig bestaande en/of recividerende klachten. Dit komt overeen met de resultaten van het onderzoek van Gerritsma en Smal, waaruit blijkt dat specialisten het tot hun tak rekenen oorzaken uit te sluiten van ziekten die minder vaak 
voorkomen, hetgeen vooral zou gelden bij patiënten die worden verwezen zonder duidelijke indicatie. (12)

Bij de beschreven groep patiënten wordt bij de verwijzingen en verrichtingen in de gebruikelijke zorg door de artsen blijkbaar eerder gehandeld op basis van impressies over ongerustheid, duur van de klacht en recidiveren van de klacht, dan op basis van 'harde' medische indicaties (ernst van de klacht en dergelijke). Min of meer 'defensieve' motieven (zie ook hoofdstuk 4) van de huisarts, die waarschijnlijk samenhangen met de context van de klacht en de patiënt, lijken in de gebruikelijke zorg bij beslissingsprocessen zwaar te wegen en vaak te resulteren in verwijzingen.

De na deze verwijzingen door de orthopaeden in grotere aantallen aangevraagde (vooral diagnostische) verrichtingen, lijken het resultaat van dezelfde motieven. Het gezamenlijk consult kan deze gewoonten blijkbaar doorbreken, omdat een voortgaande behandeling door de huisarts met minder diagnostische verrichtingen mogelijk is.

Een uitzondering vormen de operatieve behandelingen, die in beide groepen relatief in vrijwel dezelfde aantallen werden uitgevoerd.

In de literatuur is beschreven dat het aantal opnamen sterk gerelateerd is aan het aantal verwijzingen. (94-98)

Op basis van dit gegeven zou een toename van het aantal verwijzingen eveneens een toename van het aantal operaties te zien kunnen geven. Opmerkelijk is dat dit niet uit onze resultaten blijkt. De orthopaedisch chirurgen volgden bij de indicatiestelling voor operatieve behandelingen blijkbaar een consistent beleid, onafhankelijk van de verwijsfrequentie van de huisarts. Kennelijk was de verwijsindicatie in de gezamenlijk consultgroep relatief scherp.

\section{CONCLUSIES}

Het gezamenlijk consult verlengde, vergeleken met de gebruikelijke zorg, niet de periode tot het moment van verwijzing en er zijn geen aanwijzingen dat noodzakelijk te achten verwijzingen niet plaatsvinden.

Het werd gevolgd door belangrijk minder verwijzingen en diagnostische verrichtingen, en maakte het mogelijk dat een groter aantal therapeutische verrichtingen door huisartsen werd uirgevoerd.

De beperking van het aantal diagnostische verrichtingen ontstaat waarschijnlijk als gevolg van reductie van het aantal verwijzingen en omdat bij een deel van de patiënten een aantal verrichtingen en verwijzingen wordt voorkomen die in de gebruikelijke zorg vaak in samenhang met 'defensieve' motieven, zonder 'harde medische indicaties' wordt uitgevoerd.

De uitvoering door huisartsen van een aantal therapeutische handelingen dat in de gebruikelijke zorg vooral door orthopaedisch chirurgen wordt verricht, lijkt het gevolg te zijn van overname van behandelingen door huisartsen vanwege een verbetering van hun vaardigheden. Ook hierdoor wordt een aantal verwijzingen voorkomen.

Het verwijsgedrag na het gezamenlijk consult lijkt qua indicatiestelling goed te zijn afgewogen, als wordt gelet op het aantal operatieve behandelingen in beide groepen. 


\subsubsection{Kosten-baten analyse}

\section{INLEIDING}

Voor een nieuwe werkwijze zoals het gezamenlijk consult, is het niet voldoende uitsluitend af te gaan op de gevolgen voor patiënten, artsen, verrichtingen en verwijzingen. In dit verband beschreef van de Ven dat 'de ondoelmatigheid in de gezondheidszorg kan worden uitgedrukt in eenheden van (te voorkomen) medische consumptie of (mogelijk te besparen) geldbedragen' en verwees daarbij naar eerder onderzoek dat samenwerking en doelmatigheid bevorderde. (99) Het kostenverloop passend bij deze werkwijze is eveneens van belang voor de haalbaarheid. Om deze reden is getracht zo nauwkeurig mogelijk de financiële consequenties van het gezamenlijk consult vast te stellen. In de kosten-baten analyse worden de kosten die vanwege de ingangsklacht voor de patiënten van de interventiegroep vanaf het gezamenlijk consult tijdens de onderzoeksperiode voor de medische behandeling werden gemaakt, vergeleken met die van de patiënten van de controlegroep. De eventueel na het gezamenlijk consult in vergelijking met de gebruikelijke zorg vast te stellen kostendalingen kunnen als 'baten' worden beschouwd.

De financiële gevolgen van ziekreverzuim, arbeidsongeschiktheid (ervaren functioneren), ten aanzien waarvan de met betrekking tot dit onderwerp eerder beschreven resultaten van beide groepen overigens niet belangrijk verschilden (zie paragraaf 3.1.5.), zijn buiten beschouwing gelaten, waardoor het onderzoek van het kostenverloop zich beperkt tot de in de medische zorg gemaakte kosten.

Omdat we van beide groepen de gegevens met betrekking tot verrichtingen en verwijzingen hebben verzameld was het mogelijk de kosten van de medische zorg te berekenen. Dit met uitzondering van de kosten als gevolg van verwijzingen anders dan naar orthopaedie, welke laatste in beide groepen vrijwel gelijk waren.

Conform de groepsindeling gebruikt in paragraaf 3.2. zijn de kosten berekend voor de totale groepen, de behandelingen door de huisartsen en de poliklinische behandelingen door de orthopaedisch chirurgen.

De klinische behandelingen zijn buiten beschouwing gelaten, omdat het aantal opnamen en operaties tussen interventiegroep en controlegroep vrijwel niet verschilde. Dientengevolge beperkten we ons tot de kosten van de ambulante zorg. Wel moeten we ons daarbij realiseren dat van de totale kosten van de specialistische zorg, de poliklinische kosten ongeveer $1 / 3$ deel uitmaken. $(78,94)$ $\mathrm{Bij}$ de kostenberekeningen zijn we uitgegaan van de ziekenfondstarieven van 1989, hetgeen betekent dat de werkelijk gemaakte kosten (dus inclusief particulier verzekerden) gemiddeld hoger zullen zijn dan de door ons berekende.

Omdat de tarieven van de particulier verzekerden gemiddeld 50\% hoger zijn dan de ziekenfondstarieven en ongeveer $20 \%$ van de patiënten van beide groepen particulier verzekerd waren, is aangenomen dat de werkelijk gemaakte kosten ongeveer 1/9 deel hoger zullen zijn dan de op basis van de ziekenfondshonore- 
ring berekende kosten. Om deze reden is telkens $1 / 9$ deel van de kosten toegevoegd.

De bezoeken aan de huisarts werden niet in de berekening betrokken, omdat de aantallen van beide groepen vrijwel overeenkwamen.

Voor de diagnostische en therapeutische verrichtingen konden we gebruik maken van de door de Landelijke Specialisten Vereniging (L.S.V.) verstrekte tarievenlijst. Voor medicatie werd gebruik gemaakt van eenmalige standaardverstrekkingen voor pijnstillers, NSAID-middelen en middelen voor lokale infiltratietherapie door middel van injecties.

Voor behandelingen van fysio-, Cesar- en Mensendiecktherapeuten werd steeds uitgegaan van de kosten voor een twaalftal behandelingsessies.

Feitelijk zullen de kosten voor medicatie en fysiotherapie waarschijnlijk iets hoger zijn dan de door ons berekende, omdat de kosten van een aantal herhalingen niet zijn meegenomen.

Voor alle via de polikliniek orthopaedie van het AZM uitgevoerde diagnostische (röntgenfoto, laboratoriumonderzoek) en therapeutische (gipsverband, supplementen etc.) handelingen hebben we gebruik kunnen maken van de gegevens van de financiële administratie van het AZM. Voor deze gegevens zijn eveneens de ziekenfondstarieven van 1989 gebruikt.

RESULTATEN

Tabel 3.2.3.I Gemiddelde kosten per patiënt, gemaakt via de huisarts, gedurende één jaar.

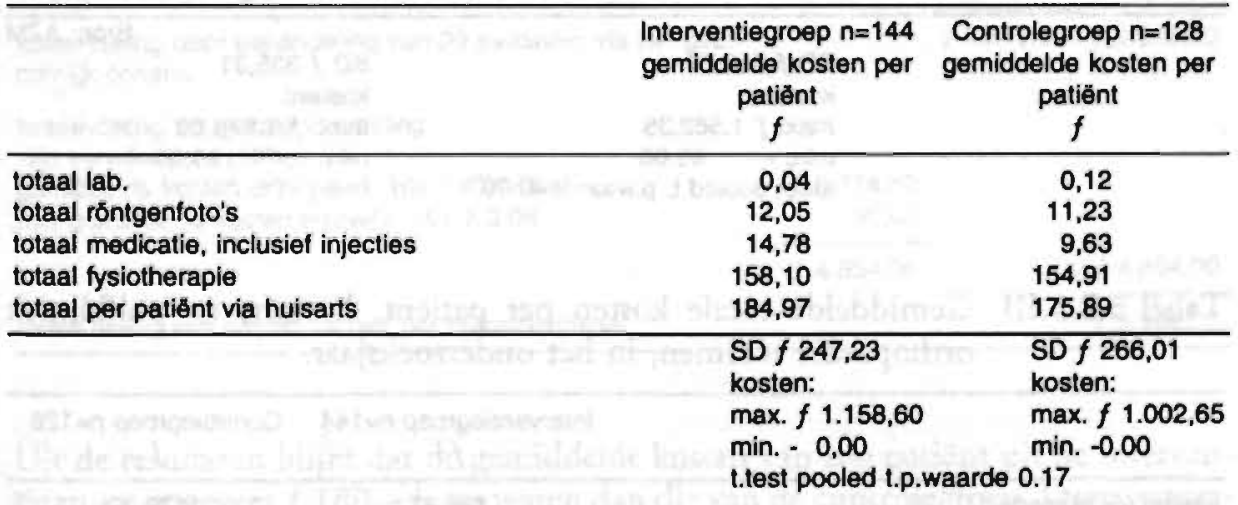

In bovenstaande tabel zien we dat de aldus berekende gemiddelde kosten gemaakt door huisartsen per patiënt voor beide groepen niet sterk uiteenlopen $(\mathrm{p}=0.17)$. De kosten ontstonden vooral door fysiotherapie.

In de interventiegroep werden de hogere kosten voor medicatie voornamelijk veroorzaakr door de injecties. 
Uit tabel 3.2.3.II blijkt dat tussen beide groepen de gemiddelde kosten per verwezen patiënt, gemaakt via de polikliniek orthopaedie, vooral verschilden wat betreft medicatie, fysiotherapie en 'gipsbehandeling'.

De gemiddelde kosten per verwezen interventiegroeppatiënt voor polibezoeken en 'gipsbehandeling' waren hoger, voor röntgenfoto's, medicatie en fysiotherapie lager dan die van de verwezen controlegroeppatiënt.

Per verwezen patiënt voor de poliklinische zorg verschilden de gemiddelde kosten niet belangrijk.

Tabel 3.2.3.II Kosten gemaakt via de polikliniek orthopaedie.

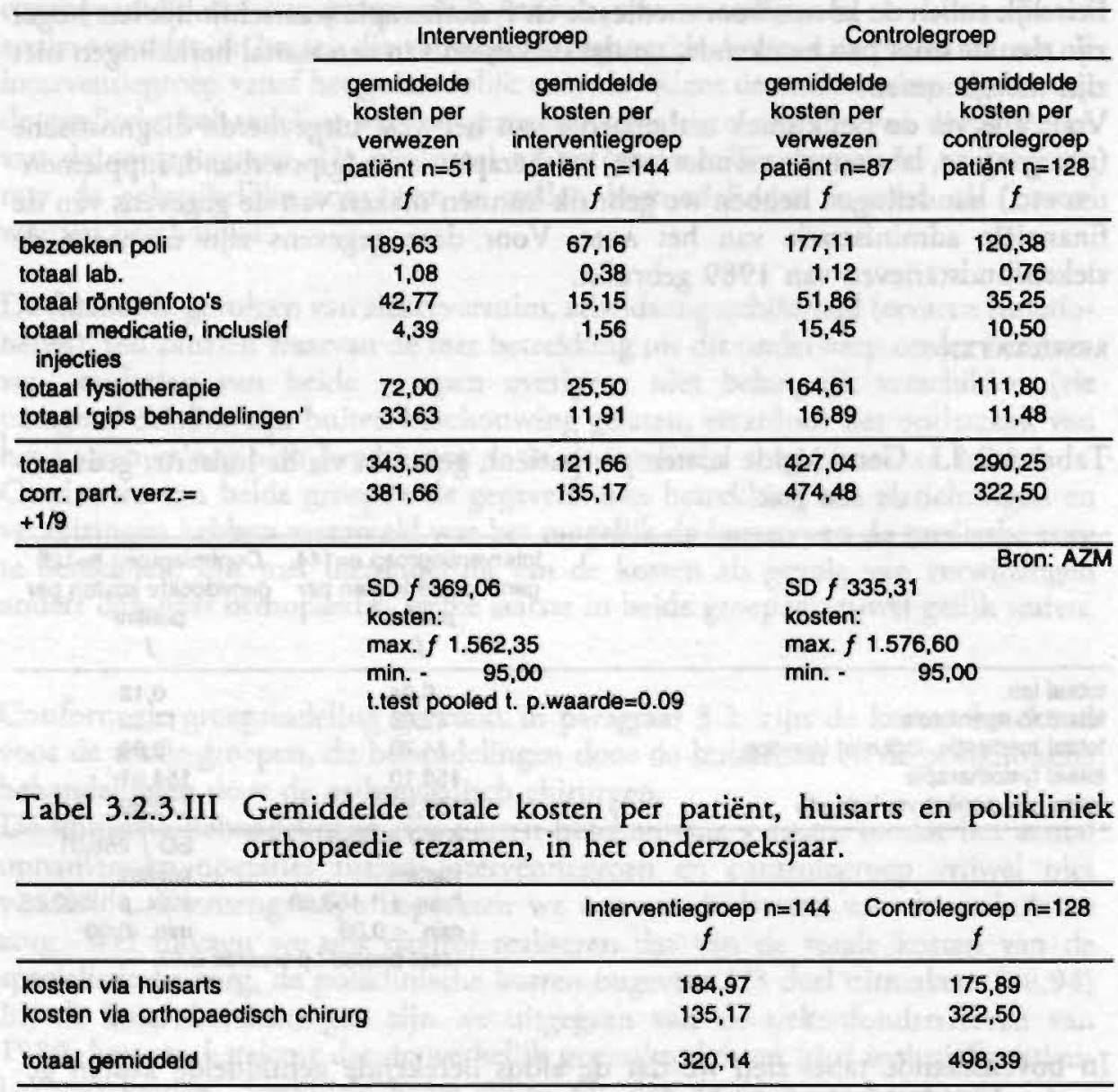

Bij tabel 3.2.3.III moet worden opgemerkt dat de gemiddelde kosten van de patiënten van de controlegroep iets hoger zullen zijn, omdat een tweetal pa- 
tiënten van deze groep via poliklinieken van streekziekenhuizen werden behandeld, waarvan geen financiële gegevens werden verkregen.

Verder blijkt hieruit een verschil van $f \quad 178,25$ tussen de gemiddelde kosten, gemaakt voor een patiënt uit de interventie- of controlegroep. De verschillen ten aanzien van medicatie en fysiotherapie zullen in feite groter zijn, omdat we voor de berekeningen van de minimale kosten vanwege eenmalige behandelsessies uitgingen.

\section{DISCUSSIE}

In de kosten-baten analyse worden de gemiddelde kosten van de patiënten van de interventiegroep vergelijken met die van de controlegroep (zie tabel 3.2.3.IV).

Tabel 3.2.3.IV

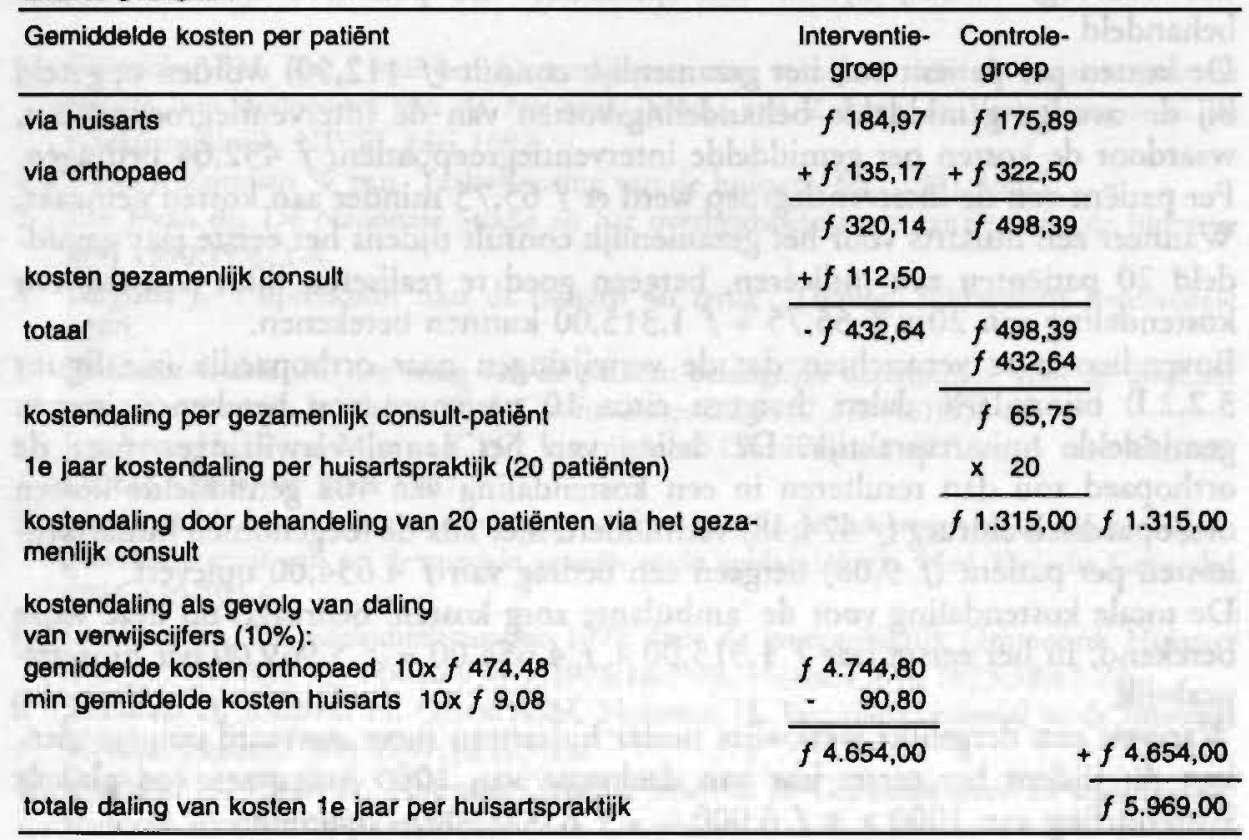

Uit de resultaten blijkt dat de gemiddelde kosten van een patiënt uit de interventiegroep ongeveer $f 180,--$ lager waren dan die van de controlegroep. Deze resultaten zijn overeenkomstig de resultaten van de verrichtingen in paragraaf 3.2.2. De gemiddelde kosten per patiënt tussen beide groepen verschilden vooral sterk, omdat de aantallen verwezen patiënten sterk verschilden.

De gemiddeld iets hogere kosten, gemaakt door de huisartsen bij patiënten in de interventiegroep, zijn te verklaren door het grotere aantal patiënten dat in deze groep uitsluitend door de huisartsen werd doorbehandeld. In de controlegroep 
werd een groter aantal patiënten verwezen en dientengevolge werd een groter aantal behandelingen door de specialist uitgevoerd, waardoor het aantal behandelingen van de huisartsen kon afnemen.

De lagere kosten per gemiddelde patiënt van de interventiegroep waren vooral het gevolg van relatief minder polikliniekbezoeken en fysiotherapiebehandelingen.

Om een completer beeld te krijgen van de kosten van de ambulante zorg, moeten de kosten van het gezamenlijk consult bij de kosten gemaakt voor patiënten van de interventiegroep worden opgeteld, en dienen eventuele veranderingen van het verwijscijfer te worden meeberekend.

De kosten van een gezamenlijk consult kunnen per patiënt worden gesteld op $f 112,50$, uitgaande van het feit dat voor een gezamenlijk consultspreekuur het honorarium voor huisartsen en orthopaedisch chirurgen tezamen $f \quad 450,00$ per uur bedroeg, waarbij tijdens één spreekuur vier patiënten konden worden behandeld.

De kosten per patiënt van het gezamenlijk consult $(f 112,50)$ worden opgeteld bij de overige gemiddelde behandelingskosten van de interventiegroeppatiënt, waardoor de kosten per gemiddelde interventiegroeppatiënt $f$ 432,64 bedragen. Per patiënt van de interventiegroep werd er $f 65,75$ minder aan kosten gemaakt. Wanneer een huisarts voor het gezamenlijk consult tijdens het eerste jaar gemiddeld 20 patiënten zou indiceren, hetgeen goed te realiseren lijkt, zou dat een kostendaling van $20 \times f 65,75=f 1.315,00$ kunnen betekenen.

Bovendien is te verwachten dat de verwijzingen naar orthopaedie (zie figuur 3.2.2.I) bijna $10 \%$ dalen, hetgeen circa 10 patiënten zou betekenen in een gemiddelde huisartspraktijk. De daling van het aantal verwijzingen naar de orthopaed zou dan resulteren in een kostendaling van 10x gemiddelde kosten orthopaedisch chirurg $(f 474,48)$ verminderd met 10x de toegenomen huisartsenkosten per patiënt $(f 9,08)$ hetgeen een bedrag van $f 4.654,00$ oplevert.

De totale kostendaling voor de 'ambulante zorg kosten' bedraagt, op deze wijze berekend, in het eerste jaar $f 1.315,00+f 4.654 .00=f 5.969,00$ per huisartspraktijk.

Wanneer een dergelijke werkwijze onder huisartsen meer aanvaard zou worden, kan dit tijdens het eerste jaar van deelname van 1000 huisartsen een globale kostendaling van $1000 \mathrm{x} \pm f 6.000,--=f 6.000 .000,--$ opleveren.

Wanneer in de volgende jaren de verwijscijfers eveneens ongeveer $10 \%$ lager blijven, zou dir jaarlijks een blijvende kostendaling van ongeveer $f 4.750,--$ per huisartspraktijk voor ambulante zorg kunnen opleveren.

Tijdens ons onderzoek is geen relatie gevonden tussen het aantal verwijzingen en het aantal operaties en/of opnamen, in tegenstelling tot hetgeen bij eerder onderzoek is vastgesteld. (78-94)

Als een dergelijke relatie wel aanwezig zou zijn, en dientengevolge het antal operaties en/of opnamen toeneemt bij een toename van het aantal verwijzingen, zullen de kostenbesparingen bij daling van de verwijsaantallen aanzienlijk groter zijn, omdat ongeveer $2 / 3$ van de kosten van specialistische zorg veroorzaakt wordt door kosten van opnamen. 
De resultaten komen overeen met de bevinding van Post en Van de Ven, dat bij studies welke of kwaliteitsverbetering of kostenverlaging als uitgangspunt nemen, vaak én betere kwaliteit én lagere kosten als resultaat hebben. $(78,99)$

Volgens hen zouden kwaliteit en doelmatigheid in de gezondheidszorg veelal hand in hand gaan.

\section{CONCLUSIES}

Het gezamenlijk consult veroorzaakt een kostendaling welke meer dan kostendekkend is, terwijl te verwachten is, dat door de daling van verwijzingen en mogelijk daarbij optredende daling van opnamen en operaties, de kostendaling beduidend kan toenemen.

\section{Literatuur}

1 Gloerich ABM, Zee J van der. Determinanten van verwijzen door de huisarts naar de tweede lijn: deelproject van de Nationale Studie van Ziekten en Verrichtingen in de Huisartspraktijk. NIVEL Mei 1992.

2 Boots J, Zutphen W van. Taakopvatting van de huisarts. MC 1981;36:65

3 Zee J van de. De Nationale Studie en het overheidsbeleid ten aanzien van de huisarts. MC 1990;19:611-4.

4 Bergsma J. 'i Spreekuur: naar de huisarts en terug'. Tilburg: Subfaculteit Psychologie 1980.

5 Hofmans-Okkes IM. De vraag van de pariënt: belangrijke determinant voor de kwaliteit van geneeskundig handelen. Ned Tijschr Geneeskd 1992;136(18):858-60.

6 Lamberts H, Wood M, c.s. ICPC: International Classification of Primary care. Oxford: Oxford University Press 1987.

7 Lamberts $\mathrm{H}$. Aan de diagnose gebonden informatie uir de huisartsprakrijk; van een op de prevalentie naar een op de episode georiënteerde epidemiologie. Ned Tijdschr Geneeskd 1986;130:292-6.

8 Lamberts H. De morbiditeitsanalyse 1972 door de groepspraktijk Ommoord. Huisarts Wet 1974;17:455-73, Huisarts Wet 1975;18:7-39, Huisarts Wet 1975;18:61-72.

9 Lamberts $\mathrm{H}$, Brouwer $\mathrm{H}$, Groen ASM, Huisman $\mathrm{H}$. Het transitiemodel in de huisartspraktijk. Huisarts Wet 1987;30:105-13.

10 Lamberts $\mathrm{H}$, Wood $\mathrm{M}$, Hofmans-Okkes I, Marinus A. Communiceren en classificeren. Huisarts Wet 1991;34(7):346-52.

11 Höppener P, Knottnerus JA, Metsemakers JFM, Kocken RJJ, Limonard ChBG. Het Registratienet Huisartsprakrijken van de Rijksuniversiteit Limburg. Huisarts Wet 1990; 33(2):66-9.

12 Gerritsma JGM, Smal JA. De werkwijze van huisarts en internist: een vergelijkend onderzoek met behulp van een interactieve patiëntensimulatie. Utrecht: Bunge 1982.

13 Zaat JOM, Schellens FG, Kluyt I et all. Laboratoriumonderzoek bij de klacht moeheid in de huisartspraktijk. Huisarts Wet 1992;35(5):183-7.

14 Kluyt I, Zaar JOM, Eyck JThM van, Velden J van der. Huisartsen en beeldvormende diagnostiek. Huisarts Wet 1992;35(5):188-91.

15 Birnie DJ. Pijn wordt langzamerhand een pijnlijk probleem. Modern Medicine 1992; 7:637-40. 
16 Groenman NH. Psychologie van de pijn. M. Matrie H., red pijninformatorium. Alphen ad Rijn: Samson Stafleu, 1980.

17 Linton SJ. Behavioral remediation of chronic pain: a status report. Pain 1986;24(2): $125-41$.

18 Birnie DJ. Predictie van chronische pijn en handicap: een medisch psychologisch onderzoek in een multidisciplinaire revalidatie-polikliniek. Proefschrift Groningen 1991.

19 Waitzkin H. Doctor-patient communication. Clinical implications of social scientific research. JAMA 1984;252(17):2441-6.

20 Jongh TOH de. Ongerustheid, een eerstelijnsziekte. MC 1987;26:828-30.

21 Cassee ETh. Naar de dokter: enkele achtergronden van ziektebeelden en gezondheidszorg. Meppel: Boom 1973.

22 Jongh TOH de. Verwijzingen, verwachtingen en effecten. MC 1986;16:511-5.

23 Kuyvenhoven MM, Spreeuwenberg C. Huisarts en diagnostisch proces. Metamedia 1984;63:18-32.

24 Southgate LJ, Bass MJ. Determination of worries and expectations of family practice patients. J Fam Pract 1983;16(2):339-44.

25 Engelsman C, Geertsema A, Haayen-Ruskamp FM. De verandering van de gezondheidstoestand en de ongerustheid van de patiënt na een verwijzing. Huisarts Wet 1993;36(4): 128-33.

26 Belleman SJM. Ontwikkeling in de vraag naar specialistische hulp: beschrijving en analyse. Utrechr: Nationaal Ziekenhuis Instituut, 1977.

27 Jongh TOH de, Lentze K. Ongerustheid en het bezoek aan de huisarts. MC 1992;27/28: 853-6.

28 Lamberts H. Patiëntenvoorlichting. Huisarts Wet 1981;24:263-7.

29 Bensing JM. Impliciete theorieën in onderzoek naar de patiënt-arts communicatie. Huisarts Wet 1991;34:311-9.

$30 \mathrm{Klip}$ EC. Interventiemogelijkheden van 'behavioral medicine'. MC 1990;4:117-9.

31 Meer K. van der, Smith RJA. Patiënten met chronisch klaaggedrag in de huisartsprakrijk. Huisarts Wer 1991;35(1):13-7.

32 Post D. Verwijzen en prescriprie, een paar apart. Zwolle: Regionaal Ziekenfonds Zwolle 1984.

33 Knottnerus JA. Medical decision making by general practitioners and specialists. Fam Pract 1991;8:305-7.

34 Portegijs PJM, Kraan HF, Knottnerus JA, Stoffers HEJ. Wat heet somatisatie. Huisarts Wet 1992;35(2):65-9.

35 Portegijs PJM, Kraan HF, Knottnerus JA, Stoffers HEJ. Wat heet somatisatic. Huisarts Wet 1992:36(1):18-25.

36 Kuyvenhoven MM, Jacobs HM, Touw-Otten FWMM, Es JC van. Verschillen in hulpverlening bij patiënten met vage klachten. Huisarts Wet 1986:29(3):65-71.

37 Stam J. Psychosomarische klachten: over moeilijkheden en mogelijkheden bij de hulpverlening. Huisarts Wer 1976;19:140-4.

38 Mierlo G. van, Smits A. Nerveus functionele klachten - De huisarts en het gezinsgesprek - De klacht en de huisarts. Huisarts Wet 1974;17:52-5.

39 Lamberts N, Probleemgedrag in de eerste lijn. Huisarts Wet 1975;18:492-502.

40 Verhaak PFM. Functionele klachten: de nieuwe kleren van de keizer? Huisarts Wet 1988;31 (suppl12):25-37.

41 Huygen FJA. Preventie van somatische fixarie (1). Geschiedenis van een onderzoeksprojekr. Huisarts Wet 1978;21:363-5. 
42 Lipowski ZJ. Somatization. The concept and its clinical application. Am J Psychiatry 1988;145:1358-68.

$43 \mathrm{Grol}$ R, cs. Psychosociale problemen in de huisartspraktijk. MC 1990;4:115-7.

44 Jol A, Verhaak PFM. Psychische en sociale klachten: gespreksvoering of psychofarmaca. Huisarts Wer 1989;32(3):89-95.

45 Gussekloo J, Haaren KMA van, Dekker FW. Chronisch klagende patiënten in de huisartspraktijk. Huisarts Wet 1992;35(13):500-2.

46 Velden J van der. Nationale studie in ziekten en verrichtingen in de huisartspraktijk. MC 1990;19:605-8.

47 Bos GAM van den. Zorgen voor chronisch zieken. Bohn, Scheltema en Holkema, Utrecht, 1989.

48 Meyboom-de Jong B. De oudere patiënt in beeld. Huisarts Wet 1991;34(2):82-8.

49 Bensing JM, Beerendonck PhM. Psychosociale problemen in de huisartspraktijk: weren en meten. MGV 1990;45-6:595-618.

50 Velden HGM van der. Diagnostiek van psychische stoornissen. Huisarts Wet 1991;34(4): 154-5.

51 Basis-takenpakket van de huisarts. Utrecht: LHV 1982.

52 DiMatreo MR, DiNicola DD. Sources of Assessment of Physicians Performance: A Study of Comparative Reliability and Patterns of Intercorrelation. Med Care 1981;19:829-39.

53 Bensing JM. Wie zegt dat dit een goed consult is? Huisarts Wet 1991;34(1):21-9.

54 Smits AJA, c.s. Spreekuurgedrag van huisartsen. Huisarts Wet 1985;28:121-5.

55 Swinkels H, Huisarts en patiënt in cijfers. Huisarts Wet 1990;33(13):504-10.

56 Joosten J, Drop MJ. De betrouwbaarheid en vergelijkbaarheid van drie versies van de VOEG. Gezondheid en Samenleving 1987;8(4):251-65.

57 Melker RA de, Touw-Otten FWMM, Jacobs HM, Lutrik A. De waarde van de 'Sickness Impact Profile' als uitkomstmeting. Ned Tijdschr Geneeskd 1990;134(19):946-8.

58 Witte LP de, Jacobs H, Horst F van der, Luttik A, Joosten J, Philipsen H. De waarde van de Sickness Impact Profile als maat voor het functioneren van patiënten. Gezondheid en Samenleving 1987;8(2):120-7.

59 Bruin AF de, Witte LP de, Stevens F, Diederiks JPM. Sickness Impact Profile: the state of the art of a generic functional status measure. Soc Science Med Vol 1992;35(8): 1003-14.

60 Essink-Bor ML, Agt HME van, Bonsel GJ. NHP of SIP: een vergelijkend onderzoek onder chronisch zieken. TSG 1992;70:152-9.

61 Bruin AF de, Witte LP de, Stevens FCJ, Diederiks JPM. De bruikbaarheid van de Sickness Impact Profile als generieke maat voor functionele toestand. TSG 1992;70: 160-70.

62 Bock GH de, Rijneveld SA, Haan M de. Geneeskunde en kwaliteit van leven. MC 1990; 22:701-4.

63 Krol LJ. De consument als leidend voorwerp in de gezondheidszorg: onderzoek naar achtergronden en verwijzingen naar de kinderarts. Proefschrift Universiteit van Amsterdam 1985.

64 Korsch BM, Gorri EK, Francis V. Doctor-patiënt interactions and patient satisfaction. Pediatrics 1986;42:855-70.

65 DiMatreo MR, Taranta A, Friendman HS, Prince LM. Predicting Patiënt Satisfaction from Psysicians Nonverbal Communication Skills. Med Care 1980:37:376-87.

66 Grundmeyer $\mathrm{H}$, Weert $\mathrm{H}$ van. Patiënt, huisarts en internist: een beschrijvende studie en een kwaliteitsanalyse van verwijzingen naar de internist. Proefschrift Universiteit van Amsterdam 1992. 
67 Meyboom WA. Een onderzoek naar (on)tevredenheid over de zorg van huisartsen. MC 1988;20:629-31.

68 Sixma H. Hoe tevreden zijn de mensen over de gezondheidszorg? MC 1988;15:475-6.

69 Kaptein AA. Huisbezoek: wat vindt de patiënt er van? Huisarts Wet 1979;22:504-9.

70 Lamberts H, Janssens PMH. Defensief handelen door huisartsen. Ned Tijdschr Geneeskd 1984;28:598-602.

71 Wielink G. Hoeveel kost aanvullend laboratoriumonderzoek? Huisarts Wet 1985;28: 136-8.

72 Nachemson A. The lumbar spine: An orthopaedic challenge. Spine 1976;1:9-21.

73 Nachemson A. A critical look at conservative treatment for low back pain. Hayson M.ed The lumbar spine and back pain. London: Sector, 1976:355-66.

74 Halpin SFS, Yeoman L, Dundee DD. Radiographic examination of the lumbar spine in a community hospital: an audit of current practice. Br Med J 1991;303:813-5.

75 Kluyt I, Zaat JOM, Eyk KThM, Velden J van der. Huisarts en beeldvormende diagnostiek. Resultaten uit de Nationale Studie. Huisarts Wet 1992;35:188-91.

76 Rocky PH, Richard K, c.s. The Usefulness of X-Ray Examinations in the Evaluation of Patients with Back Pain. J Fam Pract 1978;3:455-65.

77 Haaijer-Ruskamp M. Het voorschrijfgedrag van de huisarts: een studie bij 118 huisartsen nasr factoren die verschillen in voorschrijfgedrag verklaren. Proefschrift Groningen 1984.

78 Post D. Iatrogene ziekten: een onderzoek van oorsprong en omvang. Stafleu weten. uitg. Alphen a.d. Rijn 1984.

79 Lamberts H, Brouwer HJ, Groen ASM, Huisman H. Het transitiemodel in de huisartspraktijk. Huisarts Wet 1987;30:105-13.

80 Ross AK, Davis WA, Horn G, Williams R. General practice orthopaedic outpatient referrals in North Staffordsire. Br Med J 1983;287:1439-41.

81 Sandler G. Costs of unnecessary test. Br Med J 1979;11:21-4.

82 Eisenberg JM, Hershey JC. Derived thresholds. Determining the diagnostic probahilities at which clinicians initrate testing and treatment. Med Decis Making 1983;3:155-68.

83 Sturmans F, Mulder PGH. De betekenis van de prevalentie voor de predictieve waarde van een rest. TSG 1976;54:496-501.

84 Binnie GAC. Inquiries in rural practice: their incidence and management. J Royal Coll Gen Pract; 1983;33:275-7.

85 Kluijt I et al. Voor een prikje? Het gebruik van klinisch-chemische, hematologische en serologische bepalingen door de huisarts. Huisarts Wet 1991;34:67-71.

86 Zaat JOM, Eyck JThM van, Bonte HA. Mag het ook een testje minder? De invloed van een beperking van het aanvraagformulier voor laboratoriumonderzoek. Huisarts Wet 1991;34:72-77.

87 Ament A. Optimaal gebruik van diagnostische tests: een economisch-besliskundige analyse. Proefschrift Maastricht Rijksuniversiteit Limburg, Thesis 1989.

88 De Maeseneer J, Meyboom-Jong B de. Aanvullend onderzoek: meer dan sensitiviteit, specificiteit en voorspellende waarde. Huisarts Wet 1989;32(11):406.

89 Spitzer WO, Blanc FE Le, Dupuis et all. Scientific Approuch to the Assessment and Management of Activity-related Spinal Disorders: A Monograph for Clinicians. Spine 1987;12:(Suppl 7):sl-60.

90 Post D, Zanten A van. Hoe nodig is fysiotherapie? MC 1992;19:590-2.

91 Koes BW, Bouter LM, Beckerma $\mathrm{H}$ et al. Physiorherapy exercises and back pains: a blinded review. Br Med J 1991;302:1572-5.

92 Dopheide JP, Zẹe J van der. Verwijscijfers en diagnostische faciliteiten voor huisartsen. MC 1980;35:897. 
93 Groenewegen PP. Verrichtingen in de huisartspraktijk. MC 1990;19:608-11.

94 Flohl R. Massloze Medicin, Springer Verslag Berlin 1979.

95 Huygen FJA, Melker RA de. Over het verwijzen door de huisarts. MC 1973;28:1299.

96 Mokkink HGA. Ziekenfondscijfers als parameter over her handelen van huisartsen. Proefschrift Nijmegen KUN 1986.

97 Wijkel D, Zee J van der, Bakker D de. Ziekenfondsverwijscijfers van samenwerkende huisartsen. T S G 1992;70:519-26.

98 Lamberts $H$. In het huis van de huisarts: verslag van het Transitieproject. Lelystad: Meditekst 1991.

99 Ven WPMM van de, Winkens CGF, Wohrmann LJE. Doelmarigheid in de gezondheidszorg: een miljardenkwestie. Ned Tijdschr Geneeskd 1988;132(35):1623-7. 


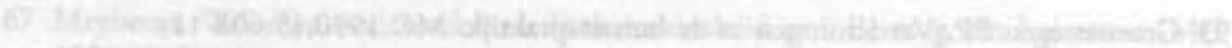

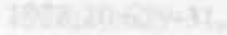

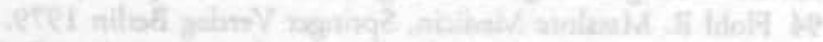

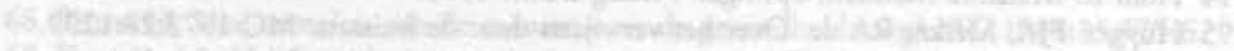

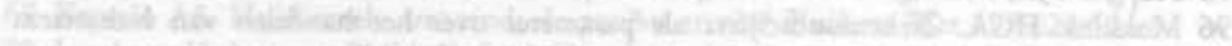

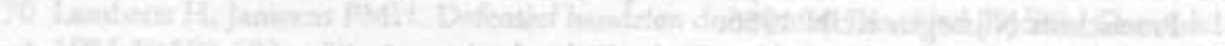

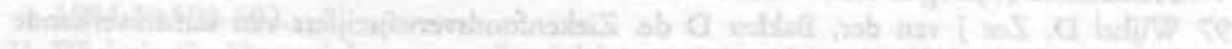

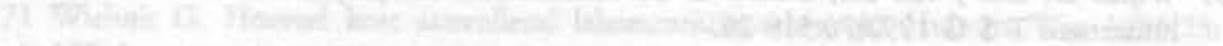

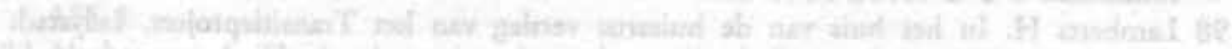

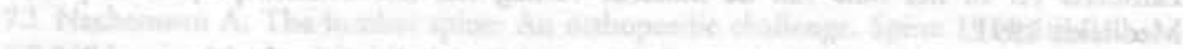

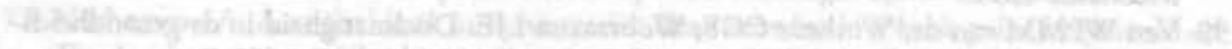

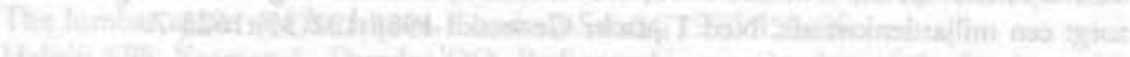

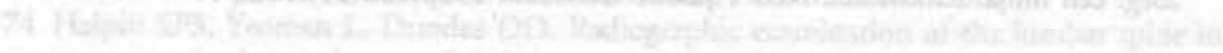

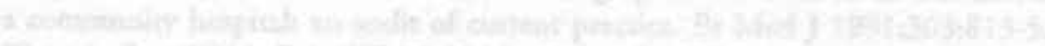

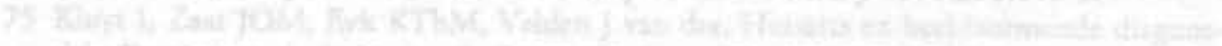

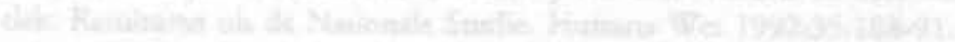

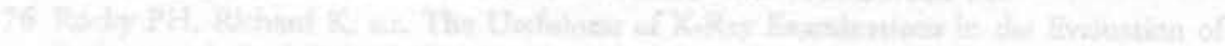

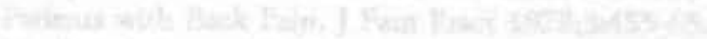

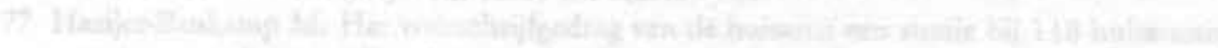

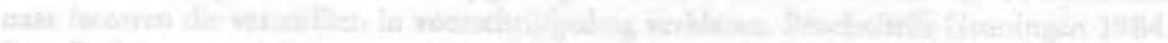

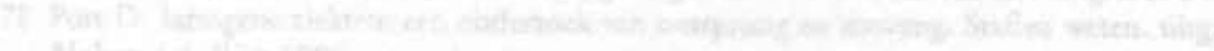

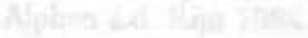

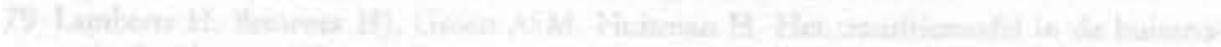

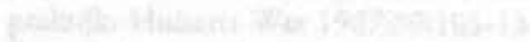

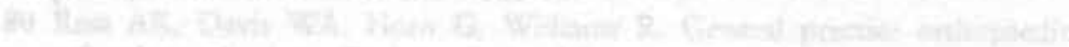

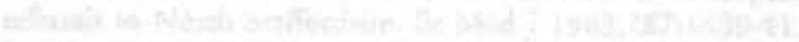

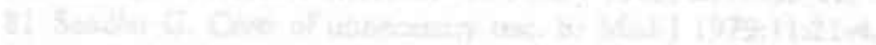

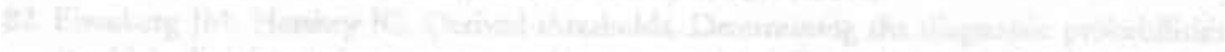

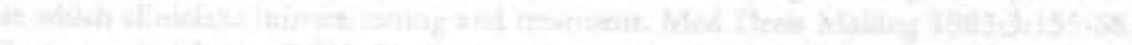

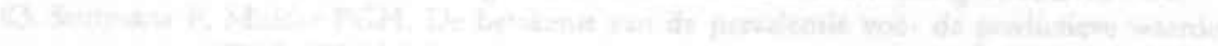

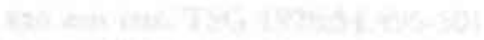

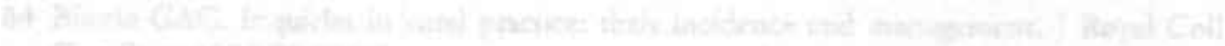

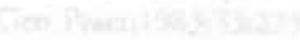

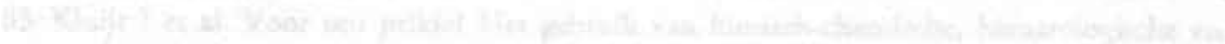

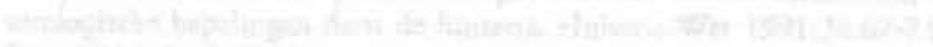

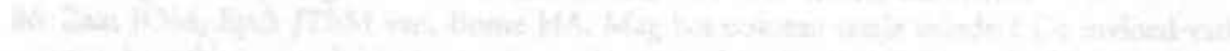

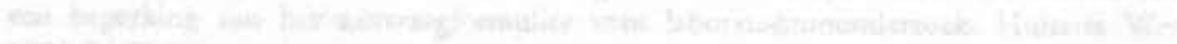

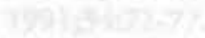

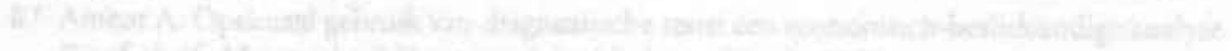

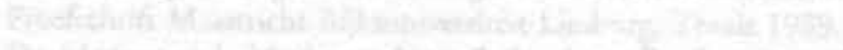

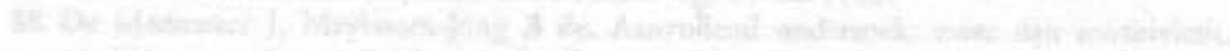

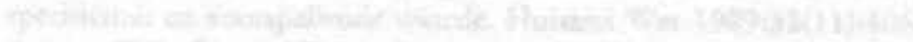

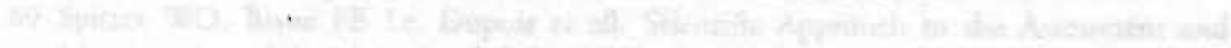

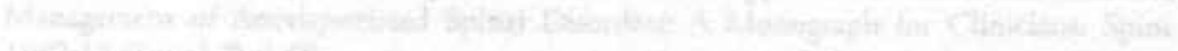

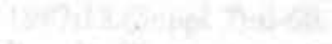

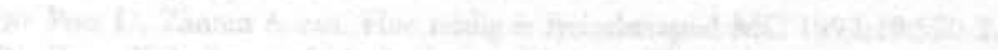

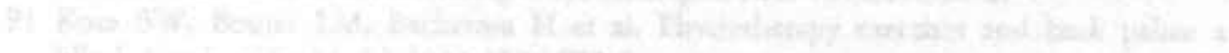

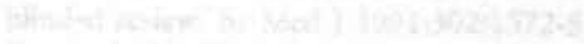

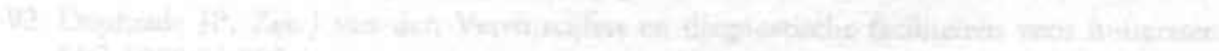
146? 


\section{Motieven, ervaringen en de deskundigheid van huisartsen bij het gezamenlijk consult}

\section{INLEIDING}

In dit hoofdstuk worden de motieven voor het gezamenlijk consult, de doelen en effecten ten aanzien van de deskundigheidsbevordering, en de satisfactie van de huisartsen beschreven.

Motieven behoren tot de voorspellende variabelen, de nascholingsvariabelen zowel tot de voorspellende als de effectvariabelen en satisfactie kan tot de effectvariabelen worden gerekend. Van alle groepen variabelen worden de resultaten achtereenvolgens beschreven en geanalyseerd.

\subsection{Motieven van huisartsen voor het gezamenlijk consult}

\section{INLEIDING}

Volgens Post heeft de mate waarmee de huisarts kan leven met onzekerheden een sterke relatie met het aantal verwijzingen. Verwijzingen zouden vaker voorkomen, wanneer de onzekerheid van de huisarts toeneemt. (1)

Ditzelfde fenomeen zou ook bij prescriptie en andere verrichtingen aanwezig zijn. De motieven voor de verwijzingen werden in eerder onderzoek op verschillende wijzen ingedeeld. Carne rubriceerde de motieven in een tweetal categorieën, te weten de 'respectable reasons' en de 'non respectable reasons'. (2)

Knottnerus, Joosten en Daams maakten een indeling, evenals Paterson, Bensing en Verhaak die hierbij een drietal typen redenen voor verwijzing onderscheidden:

(3-5)

- verwijzingen pro diagnose;

- verwijzingen pro therapie;

- wanhoopsverwijzingen.

De overdracht van de verantwoordelijkheid (verdere behandeling) zou tussen de onderscheiden typen verschillen.

De indeling in motieven voor verwijzing welke Van Es gebruikte in zijn onderzoek naar verwijzingen, bestaat uit 8 categorieën. (6)

Hij wees op het bestaan van onbewuste motieven en voor het 'dooreen spelen' van motieven.

Voor het effectiviteitsonderzoek zijn de motieven voor het gezamenlijk consult meer gedetailleerd ingedeeld. 
Gebruikt is een indeling van 10 categorieën, waarvan de huisarts tijdens de instroomconsulten, vanwege het beschreven 'dooreen spelen van motieven', er telkens één of meer kon aankruisen.

De indeling onderscheidt de volgende motieven:

1 onzeker over de diagnose

2 second-opinion ter voorkomen van verwijzing

3 kennisvermeerdering

4 vaardigheden ontwikkelen

5 overbodige verwijzing voorkomen

6 overleg in verband met te verwachten verwijzing

7 somatische fixatie voorkomen

Daarnaast zijn er motieven, ingegeven door gepercipiceerde wensen en verwachtingen van de patiënt.

8 patiënt was ongerust

9 patiënt vroeg om verwijzing

10 anders.

De motieven 1, 2 en 3 zouden overeen kunnen komen met het motief 'pro diagnose' van de indeling van Bensing en Verhaak. De motieven 3 en 4 met het motief 'pro therapie' en de motieven 2,5,7,8 en 9 met het motief 'wanhoopsverwijzingen'. Deze laatste motieven (2,5,7,8 en 9) zouden ook 'defensieve' motieven genoemd kunnen worden. Het motief 6 'wilde overleg in verband met te verwachten verwijzing' is een typisch consultatiemotief en valt derhalve buiten de genoemde indeling. Ook met de categorieën van de indeling van Van Es zijn overeenkomsten aan te geven.

\section{RESULTATEN}

Tabel 4.1.I laat zien dat tijdens de instroom ook op dit gebied geen belangrijke verschillen tussen beide groepen werden vastgesteld. De motieven verschillen onderling wel sterk in aantal, hetgeen niet verrast.

Het motief 'kennisvermeerdering'(nr.3) scoorde in beide groepen het hoogst, gevolgd door 'overbodige verwijzing voorkomen'(nr.5).

Alleen het motief 'patiënt vroeg verwijzing' (nr.9) verschilt significant tussen de groepen $(\mathrm{p}=0.02)$.

In tabel 4.1.II zijn de motieven gerelateerd aan de verwijzingen tijdens de onderzoeksperiode. Hierbij is bij de 'verwijscijfers' in de subgroepen gelet op afwijkingen van de totale verwijspercentages van interventiegroep $(35 \%)$ of controlegroep (68\%) (motieven 1, 4, en 6). Motieven waarvan de resultaten vrijwel conform deze totale verwijspercentages zijn, werden niet in tabel 4.1.II opgenomen (motieven 2, 3, 5, 7,8 en 9).

De 'defensieve' motieven tezamen werden in beide groepen ongeveer even vaak aangekruist als de diagnostische en therapeutische motieven tezamen. 
Tabel 4.1.I Vragen ten aanzien van motieven, gesteld aan huisartsen voor beide groepen patiënten tijdens instroomconsulten (meer antwoorden aan te kruisen).

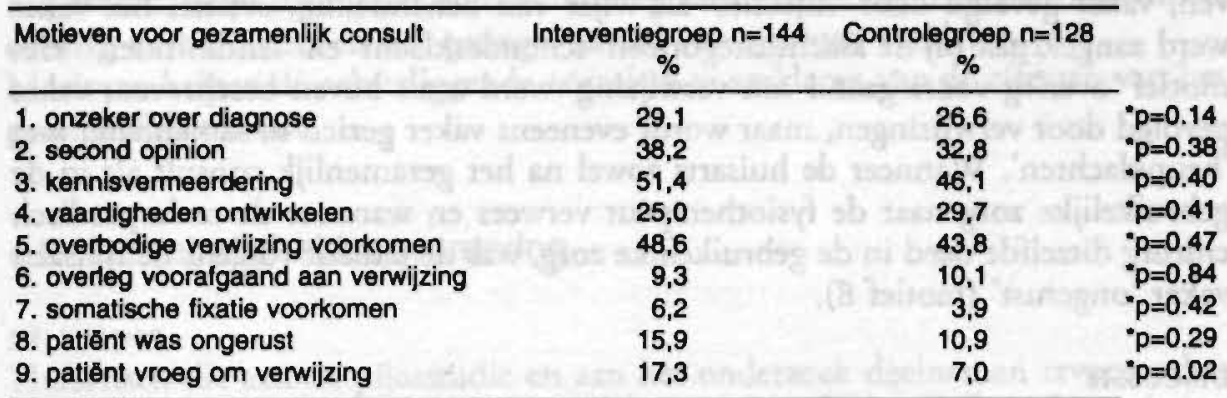

Fisher's Exact Test

Tabel 4.1.II Motieven van huisartsen voor beide groepen tijdens instroomconsulten, gerelateerd aan de verwijzingen tijdens de onderzoeksperiode.

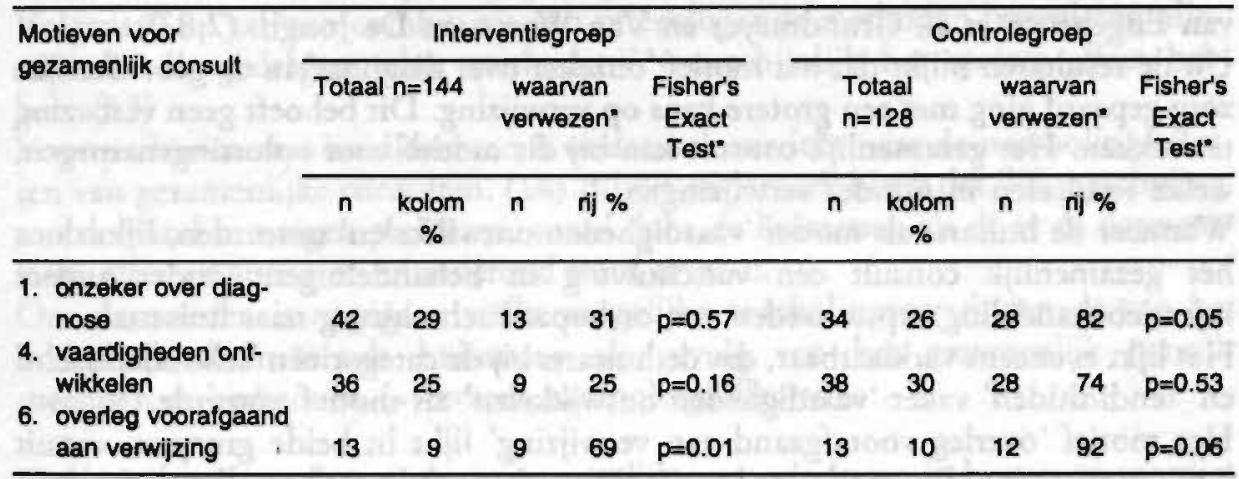

In de controlegroep zien we in de subgroep met motief 1 ('onzeker over diagnose') een verhoogd aantal verwijzingen ten opzichte van het totale aantal verwijzingen in de controlegroep $(\mathrm{p}=0.05)$.

Het motief nr.4 ('vaardigheden ontwikkelen') werd in de interventiegroep gevolgd door een laag percentage verwijzingen, het verschil met het verwijspercentage van de groep die dit motief niet had in de interventiegroep, was echter niet significant $(\mathrm{p}=0.16)$.

De sub-groep patiënten waarbij de huisartsen motief 6 ('overleg voorafgaand aan verwijzing') aankruisten werd, vergeleken met de sub-groep patiënten die dit motief niet kregen, in de interventiegroep gevolgd door een significant hoger $(p=0.01)$ verwijspercentage.

De motieven van huisartsen voor het gezamenlijk consult zijn eveneens door middel van multipele en lineaire regressie analyses in verband gebracht met de diverse effectvariabelen. (zie bijlagen 17-32) 
Achtergronden van de veranderde aantallen verwijzingen en verrichtingen na het gezamenlijk consult, kunnen met deze analyses worden verduidelijkt.

Het motief 'vaardigheden ontwikkelen' (nr.4) werd, zoals reeds eerder is beschreven, vaker gevolgd door 'injecties' als wijze van behandeling, evenals het vaker werd aangekruist bij de klachtcategorieën 'schouderklacht' en 'tendinitiden'. Het motief 'overleg voorafgaand aan verwijzing' werd zoals boven beschreven, vaker gevolgd door verwijzingen, maar wordt eveneens vaker gezien in samenhang met 'heupklachten'. Wanneer de huisarts zowel na het gezamenlijk consult als in de gebruikelijke zorg naar de fysiotherapeur verwees en wanneer de orthopaedisch chirurg ditzelfde deed in de gebruikelijke zorg, was de patiënt volgens de huisarts vaker 'ongerust' (motief 8 ).

\section{DISCUSSIE}

Motieven voor het gezamenlijk consult bleken bij huisartsen het vaakst 'kennisvermeerdering', 'overbodige verwijzing voorkomen' en 'second opinion', gevolgd door 'vaardigheden ontwikkelen' en 'onzekerheid over diagnose'.

Defensieve motieven van huisartsen speelden dikwijls (ongeveer bij de helft van de patiënten) een rol. Dit komt overeen met de resultaten van de onderzoeken van Engelsman et al, Grundmeyer en Van Weert, en De Jongh. $(7,8,9)$

Uit de resultaten blijkt dat het motief 'onzeker over diagnose' in de gebruikelijke zorg gepaard ging met een grotere kans op verwijzing. Dit behoeft geen verbazing te wekken. Het gezamenlijk consult kan bij dit motief voor oplossingen zorgen, welke resulteren in minder verwijzingen.

Wanneer de huisarts als motief 'vaardigheden ontwikkelen' noteerden, lijkt door het gezamenlijk consult een verschuiving in behandelingen (onder andere injectiebehandeling) op te treden van orthopaedisch chirurg naar huisarts.

Het lijkt eveneens verklaarbaar, dat de huisarts bij de categorieën 'schouderklacht' en 'tendinitiden' vaker 'vaardigheden ontwikkelen' als motief noteerde.

Het motief 'overleg voorafgaand aan verwijzing' lijkt in beide groepen, vanuit huisartsgeneeskundig standpunt begrijpelijk, vaker gerelateerd aan 'heupklachten' en met 'verwijzingen naar de orthopaedisch chirurg'. Het grote aantal verwijzingen bij het motief 'overleg voorafgaand aan verwijzing' lijkt logisch, al worden niet alle patiënten bij wie dit motief geldt achteraf verwezen. Het motief 'patiënt was ongerust' gerelateerd aan 'verwijzingen van huisarts voor fysiotherapie' werd al eerder beschreven bij de verrichtingen.

Een aantal motieven van de huisartsen lijkt, zoals reeds eerder werd beschreven in paragraaf 3.2.2., de achtergronden van de effecten van het gezamenlijk consult mede te verklaren.

\section{CONCLUSIES}

Het gezamenlijk consult werd vergeleken met de gebruikelijke zorg vooral vaker gevolgd door minder verwijzingen, wanneer de huisarts als motief 'onzeker over diagnose' noteerde.

Het motief voor het gezamenlijk consult 'vaardigheden ontwikkelen' kwam zowel vaak voor bij de behandeling door middel van 'injectie' als aan de categorieën 
'schouderklachten' en 'tendinitiden'. Omdat de huisarts door het gezamenlijk consult vaker zelf de injectiebehandeling toepaste en omdat deze behandelwijze vaak bij de frequent aangeboden 'schouderklachten' en 'tendinitiden' werd uitgevoerd, helpt dit motief de verschuiving van verrichtingen van orthopaedisch chirurg naar huisarts en het geringer aantal verwijzingen verklaren.

Motieven helpen de achterliggende oorzaken te verklaren van de effecten van het gezamenlijk consult.

\subsection{Deskundigheidsbevordering}

INLEIDING

Huisartsen die aan de pilotstudie en aan het onderzoek deelnamen ervoeren het gezamenlijk consult als een belangrijke vorm van deskundigheidsbevordering (nascholingseffecten). (10)

Deze ervaringen zijn van belang omdat uit eerder onderzoek is gebleken, dat op kennisvergroting en attitudeverandering gerichte deskundigheidsbevordering alléén onvoldoende is om praktijkgedrag te beïnvloeden en te veranderen. $(11,12)$ Volgens Grol zal 'een combinatie van uiteenlopende methoden (zowel cognitie-, attitude- als gedragsgerichte methoden)' waarschijnlijk het meeste effect hebben. (13)

Voor patiënten met huidklachten is onderzoek verricht naar de nascholingseffecten van gezamenlijke consulten. (14) Bij dit onderzoek bleek dat 'life-nascholing' aan de hand van eigen patiënten, zowel door de huisartsen als door de dermatoloog, als zeer nuttig en stimulerend werd ervaren.

Om deze reden is nagegaan welke mogelijke nascholingservaringen de aan het onderzoek deelnemende huisartsen als gevolg van het gezamenlijk consult meenden te herkennen ( $=$ ervaren nascholingseffecten).

Ook werd onderzoek verricht naar mogelijke veranderingen in kennis en vaardigheden bij de huisartsen ten gevolge van het gezamenlijk consult ('toetsingsonderzoek').

\section{METHODE}

\section{Ervaren nascholingseffecten}

Om een beeld te krijgen van de door de huisartsen gepercipieerde nascholingseffecten werden hierover tijdens de instroom- en eindconsulten vragen gesteld.

Tijdens de instroomconsulten gebeurde dit door middel van vragen over de motieven voor het gezamenlijk consult. Hiervan betrof een aantal (betreffende kennisvermeerdering en ontwikkeling vaardigheden) in feite nascholingsdoelen. $\mathrm{Bij}$ de eindconsulten werd bij iedere patiënt aan de huisarts gevraagd of deze sinds het betreffende instroomconsult een patiënt met een identiek probleem (=herhalingsklacht) was tegengekomen, en zo ja, of hij die patiënt dan zelfstandig had behandeld. Tevens werd gevraagd waardoor dat naar zijn mening nu mogelijk was. 


\section{Toetsingsonderzoek}

Om inzicht te krijgen in het optreden van veranderingen in het kennis- en vaardighedenniveau van huisartsen op het gebied van klachten van het bewegingsapparaat, hebben de deelnemende huisartsen (=onderzoek-toetsgroep) en een qua praktijkervaring equivalente groep van 12 huisartsen uit de regio (=controletoetsgroep) voorafgaand aan en bij het eind van het onderzoek deelgenomen aan een schriftelijk toetsingsonderzoek.

De toetsing bestond beide malen uit dezelfde vragenlijst van 103 vragen, door drie ervaren huisartsen gekozen uit het vragenbestand op het gebied van orthopaedie van de Maastrichtse voortgangstoets van de Faculteit der Geneeskunde van de Rijksuniversiteit Limburg.

Dit bestand bevat vragen die als relevant voor een basisarts worden beschouwd. De vragenlijsten bevatten vooral kennisvragen op het gebied van het bewegingsapparaat ('kennisvragen') en voor een kleiner deel vragen ten aanzien van vaardigheden ('vaardigheidsvragen').

De vragenlijst bij de voormeting bevatte 90 'kennisvragen' en 13 'vaardigheidsvragen', die van de nameting 96 'kennisvragen' en 22 'vaardigheidsvragen'.

De huisartsen van beide groepen waren respectievelijk gemiddeld 16 jaar (7-31 jaar) (onderzoek-toetsgroep) en gemiddeld 16 jaar (5-27 jaar) (controle-toetsgroep) als huisarts werkzaam.

Omdat in de onderzoeksgroep één huisarts van vestigingsplaats veranderde en één huisarts de deelname beëindigde, bestond deze groep voor dit onderzoek uit 10 huisartsen.

Vanwege praktische omstandigheden werd bij de voormeting de vragenlijst bij 8 van de 10 aan het onderzoek deelnemende huisartsen gestandaardiseerd afgenomen, terwijl de overige 2 huisartsen en de huisartsen van de controlegroep de vragenlijsten thuis invulden. Bij de eindmeting werden door alle huisartsen de vragenlijsten binnen 45 minuten ingevuld in aanwezigheid van één van de onderzoekers.

De vragen werden beantwoord met behulp van de mogelijkheden 'juist', 'onjuist' of 'vraagteken'. De score is het aantal correcte minus het aantal foute antwoorden, uitgedrukt als proportie van het totale aantal vragen (\% goed minus fout score).

\section{RESULTATEN}

\section{Ervaren nascholingseffecten}

Uit tabel 4.2.I blijkt voor beide groepen dat de huisartsen bij meer dan de helft van de voor het gezamenlijk consult geselecteerde patiënten (interventiegroep $59 \%$, controlegroep $56 \%, \mathrm{p}=0.96$ ) meenden dat er een klacht was aangeboden die zij binnen het onderzoeksjaar nogmaals zagen. 
Tabel 4.2.I Mate waarin huisartsen menen klachten voor gezamenlijke consulten binnen één jaar opnieuw te hebben gezien. Vraag aan huisarts tijdens eindconsult: 'Heeft U afgelopen jaar identieke klachten gezien?'

\begin{tabular}{|c|c|c|c|c|c|c|c|c|}
\hline \multirow{2}{*}{\multicolumn{3}{|c|}{ Identieke problemen gezien }} & \multirow{3}{*}{ 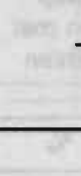 } & \multicolumn{3}{|c|}{ Interventiegroep* n=144 } & \multicolumn{2}{|c|}{ Controlegroep $n=128$} \\
\hline & & & & \multicolumn{2}{|c|}{$\begin{array}{c}\text { totaal } \\
n\end{array}$} & \multirow{2}{*}{$\begin{array}{l}\% \\
59\end{array}$} & \multirow{2}{*}{$\begin{array}{c}\begin{array}{c}\text { totaal } \\
n\end{array} \\
72\end{array}$} & \multirow{2}{*}{$\begin{array}{l}\% \\
56\end{array}$} \\
\hline ja & 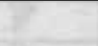 & 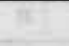 & & 85 & Fin & & & \\
\hline $\begin{array}{l}\text { nee } \\
\text { niet ingevuld }\end{array}$ & 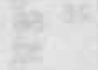 & (n) & $\frac{78}{8}$ & 59 & $\frac{5}{41}$ & 41 & $\begin{array}{r}51 \\
5\end{array}$ & $\begin{array}{r}40 \\
4\end{array}$ \\
\hline totaal & 4 & II & 8 & 144 & 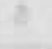 & 100 & 128 & 100 \\
\hline
\end{tabular}

- Chi-kwadraattoets $p=0.96$ (getoetst met item 'niet ingevuld" als missing).

Tabel 4.2.II Mate waarin huisartsen menen patiënten met identieke klachten nadien zelfstandig te hebben behandeld. Vraag aan huisarts tijdens eindconsult, bij klachten waarbij sinds het instroommoment een identieke klacht was aangeboden: 'Heeft u dergelijke patiënten dan zelfstandig behandeld?'

\begin{tabular}{|c|c|c|c|c|}
\hline \multirow{2}{*}{$\begin{array}{l}\text { Eindconsult } \\
\text { Identieke problemen gezien en zelf behan- } \\
\text { deld }\end{array}$} & \multicolumn{2}{|c|}{ Interventiegroep* } & \multicolumn{2}{|c|}{ Controlegroep } \\
\hline & $\begin{array}{l}\text { totaal } \\
n=85\end{array}$ & $\%$ & $\begin{array}{l}\text { Iotaal } \\
n=72\end{array}$ & $\%$ \\
\hline $\begin{array}{l}\text { ja } \\
\text { twijfel } \\
\text { nee }\end{array}$ & $\begin{array}{r}73 \\
3 \\
9\end{array}$ & $\begin{array}{r}86 \\
4 \\
10\end{array}$ & $\begin{array}{r}59 \\
2 \\
11\end{array}$ & $\begin{array}{r}82 \\
3 \\
15\end{array}$ \\
\hline totaal & 85 & 100 & 72 & 100 \\
\hline
\end{tabular}

Chi-kwadraattoets $\mathrm{p}=0.52$ (getoetst met ilem 'twijfel' als missing).

Uit tabel 4.2.II blijkt dat zij van deze 'identiek aan eerder aangeboden' klachten het grootste deel (interventiegroep $86 \%$, controlegroep $82 \%$ ) zelf behandelden. De redenen, die huisartsen aangeven voor het feit dat zij meenden patiënten met 'herhalingsklachten' nadien zelfstandig zijn gaan behandelen, staan vermeld in tabel 4.2.III. 
Tabel 4.2.III Volgens huisarts nu zelfstandig behandelde patiënten met identieke klachten bij interventie- en controlegroep tijdens eindconsulten. (Het invullen van meer redenen per geval was mogelijk).

\begin{tabular}{|c|c|c|c|c|c|}
\hline $\begin{array}{l}\text { Redenen van het nu zellstandig } \\
\text { behandelen }\end{array}$ & $\begin{array}{r}\text { Inte } \\
\text { aantal } \\
\text { herhe }\end{array}$ & $\begin{array}{l}\text { ventiegroep } \\
\text { patiēnten met } \\
\text { lingsklachten } \\
\mathrm{n}=73\end{array}$ & $\begin{array}{r}\text { Co: } \\
\text { aantal } \\
\text { herhe }\end{array}$ & $\begin{array}{l}\text { en met } \\
\text { achiten }\end{array}$ & \\
\hline 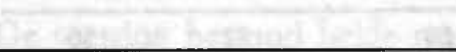 & n & $\%$ & $n$ & $\%$ & \\
\hline $\begin{array}{l}\text { meer kennis } \\
\text { gegevens beter interpreteren } \\
\text { gerichter aanvullende diagnostische } \\
\text { aanvragen }\end{array}$ & $\begin{array}{r}39 \\
19 \\
5\end{array}$ & $\begin{array}{r}51 \\
25 \\
7\end{array}$ & $\begin{array}{r}34 \\
20 \\
5\end{array}$ & $\begin{array}{r}56 \\
33 \\
8\end{array}$ & $\begin{array}{l}p=0.86 \\
p p=0.45 \\
p p=1.00\end{array}$ \\
\hline $\begin{array}{l}\text { vaardigheden verbeterd } \\
\text { therapeutische behandelingen } \\
\text { verbelerd }\end{array}$ & $\begin{array}{l}31 \\
25\end{array}$ & $\begin{array}{l}41 \\
33\end{array}$ & $\begin{array}{l}18 \\
22\end{array}$ & $\begin{array}{l}30 \\
36\end{array}$ & $\begin{array}{l}-p=0.15 \\
" p=0.86\end{array}$ \\
\hline $\begin{array}{l}\text { geen second opinion meer nodig } \\
\text { patient beter geruststellen } \\
\text { specialist heeft niet meer te bieden }\end{array}$ & $\begin{array}{l}25 \\
24 \\
17\end{array}$ & $\begin{array}{l}33 \\
32 \\
22\end{array}$ & $\begin{array}{l}18 \\
18 \\
15\end{array}$ & $\begin{array}{l}30 \\
30 \\
25\end{array}$ & $\begin{array}{l}p p=0.58 \\
p=0.71 \\
p p=1.00\end{array}$ \\
\hline
\end{tabular}

- Fisher's Exact Test

Uit deze tabel blijkt dat volgens de huisartsen de toegenomen kennis en/of verbeteringen van de vaardigheden daarbij een belangrijke rol speelden. In de interventiegroep scoorde vooral de verbetering van de vaardigheden wat hoger dan in de controlegroep $(\mathrm{p}=0.15)$.

Voor de overige redenen verschillen beide groepen minder.

\section{Kennis- en vaardighedenonderzoek (toetsingsonderzoek)}

In de figuren 4.2.IV en $\mathrm{V}$ van het toetsingsonderzoek, met name gericht op kennis en vaardigheden, zien we de gemiddelde scores en de $95 \%$ betrouwbaarheidsintervallen van beide groepen huisartsen bij voor- en nameting voor de totale set toetsvragen en voor de vaardigheidsvragen afzonderlijk. Er komen geen significante verschillen naar voren.

Bij de huisartsen van de onderzoek-toetsgroep is een mogelijk trendmatige vooruitgang te zien bij de vaardigheidsvragen (figuur 4.2.V). Wel moet worden opgemerkt, dat aan dit toetsingsonderzoek slechts kleine aantallen huisartsen deelnamen die een gering aantal vragen beantwoordden. Bovendien was de tweede toets qua samenstelling van de vragen en de wijze van afname niet geheel gelijk aan de eerste. 
Figuur 4.2.IV Gemiddelde scores en $95 \%$ betrouwbaarheidsintervallen van de totale sets toetsvragen van beide groepen (onderzoeks- en controlegroep) huisartsen bij voor- en nameting.

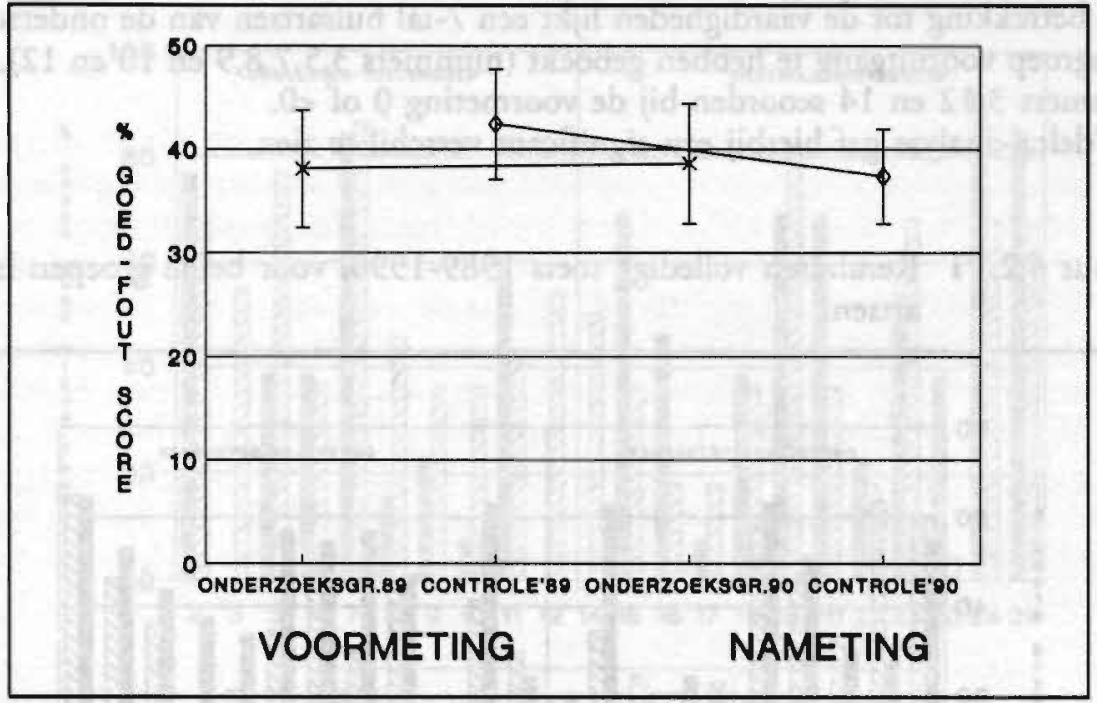

$X=$ onderzoeksgroep

$0=$ controlegroep

Figuur 4.2.V Gemiddelde scores en $95 \%$ betrouwbaarheidsintervallen van de sets vaardigheidsvragen van beide groepen (onderzoeks- en controlegroep) huisartsen bij voor- en nameting.

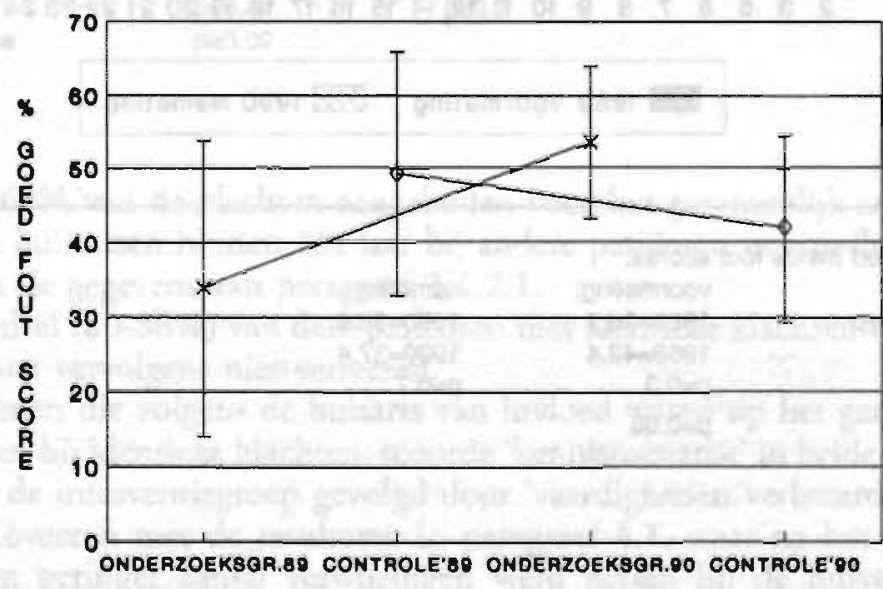

VOORMETING

NAMETING 
Bij vergelijking van de afzonderlijke resultaten van de individuele huisartsen (figuren 4.2.VI en VII) zien we bij een aantal huisartsen bij de nameting een opvallende achteruitgang.

Met betrekking tot de vaardigheden lijkt een 7-tal huisartsen van de onderzoektoetsgroep vooruitgang te hebben geboekt (nummers 3,5,7,8,9 en 10 en 12). De nummers 3,12 en 14 scoorden bij de voormeting 0 of $<0$.

De 'delta'-analyse gaf hierbij een significant verschil te zien.

Figuur 4.2.VI Resultaten volledige toets 1989-1990, voor beide groepen huisartsen.

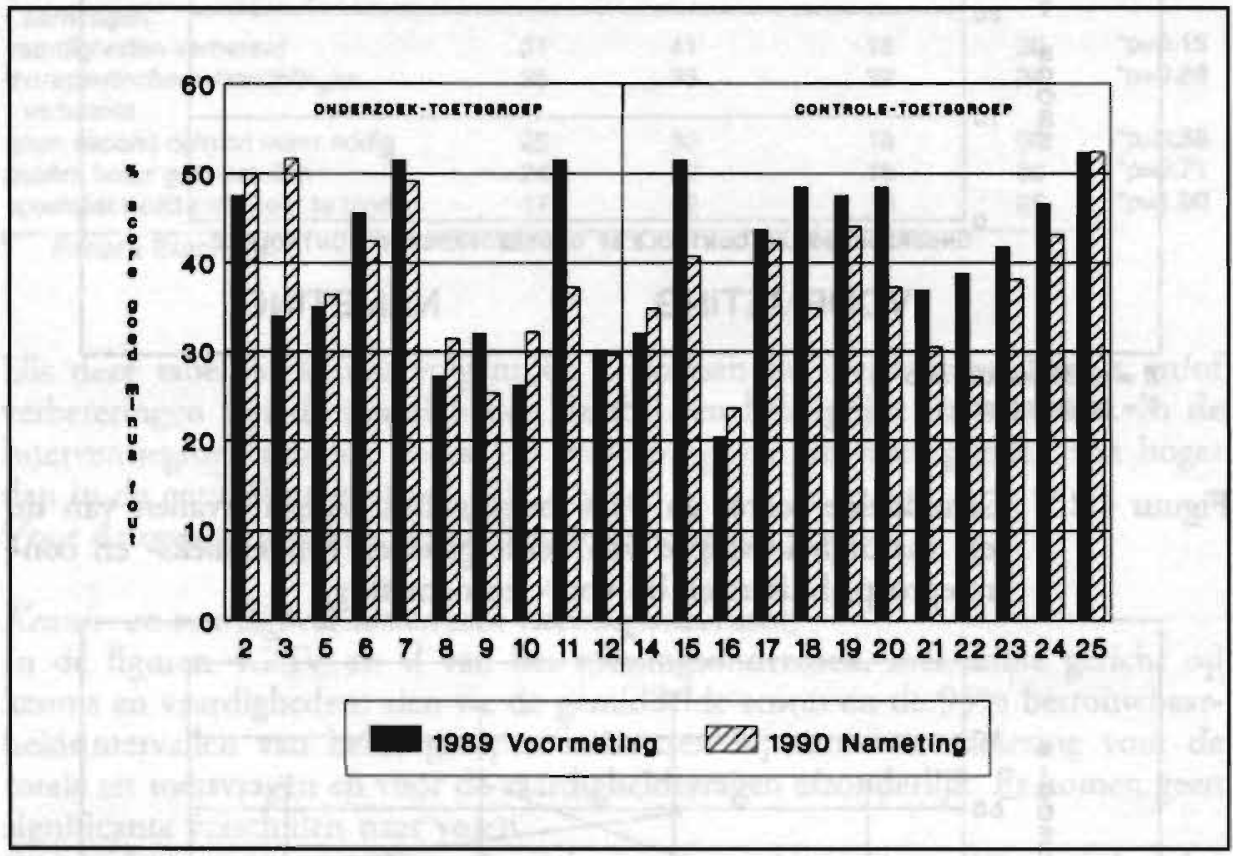

Gemiddelde goed minus fout scores:

$\begin{array}{lll} & \text { voometing: } & \text { nameling: } \\ \text { Onderzoeksgroep } & 1989=38.1 & 1990=38.6 \\ \text { Controlegroep } & 1989=42.4 & 1990=37.4 \\ \text { T-toets } & p=0.3 & p=0.7 \\ \text { Delta'-analyse } & p=0.08 & \end{array}$


Figuur 4.2.VII Resultaten van de subgroep vaardigheden van de toets 19891990, voor beide groepen huisartsen.

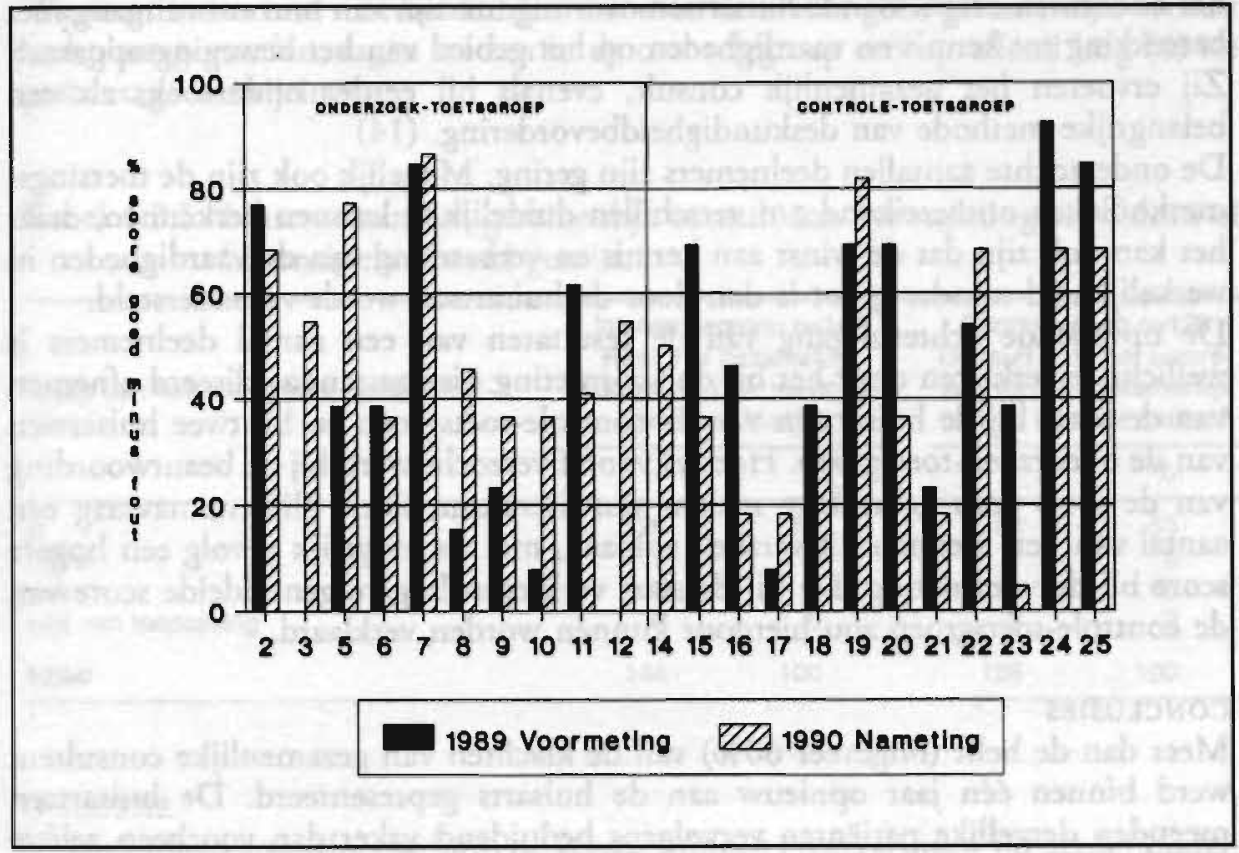

Gemiddelde goed minus fout scores:

$\begin{array}{lll} & \text { voometing: } & \text { nameting: } \\ \text { Onderzoeksgroep } & 1989=33.9 & 1990=53.6 \\ \text { Controlegroep } & 1989=49.4 & 1990=42.0 \\ \text { T-toets } & p=0.4 & p=0.2 \\ \text { 'Delta'-analyse } & p=0.02 & \end{array}$

\section{DISCUSSIE}

Ongeveer $60 \%$ van de klachten aangeboden voor het gezamenlijk consult, werd volgens de huisartsen binnen éen jaar bij andere patiënten nogmaals gezien. Dit is conform de gegevens van paragraaf 3.1.2.1.

Een groot deel (80-86\%) van deze patiënten met identieke klachten werd volgens de huisartsen vervolgens niet verwezen.

Bij de redenen die volgens de huisarts van invloed waren op het geringer aantal verwijzingen bij identieke klachten, scoorde 'kennistoename' in beide groepen het hoogst, in de interventiegroep gevolgd door 'vaardigheden verbeterd'.

Dit komt overeen met de resultaten in paragraaf 4.1. waar na het gezamenlijk consult een geringer aantal verwijzingen werd gezien bij de huisartsmotieven 'onzeker over diagnose' en 'vaardigheden ontwikkelen'. Kennistoename sluit immers goed aan op het motief 'onzeker over diagnose'.

De resultaten van de toetsingsonderzoeken geven, behoudens een mogelijk trendmatige aanwijzing ('delta'-analyse $\mathrm{p}=0.02$ ) dat bij de huisartsen van de onder- 
zoeksgroep de kennis over de vaardigheden met betrekking tot het bewegingsapparaat is toegenomen, geen belangrijke verschillen te zien. Wel meldden de aan het onderzoek deelnemende huisartsen overtuigd te zijn van hun vooruitgang met betrekking tot kennis en vaardigheden op het gebied van het bewegingsapparaat. $\mathrm{Zij}$ ervoeren het gezamenlijk consult, evenals bij eerder onderzoek, als een belangrijke methode van deskundigheidbevordering. (14)

De onderzochte aantallen deelnemers zijn gering. Mogelijk ook zijn de toetsingsmethodieken ontoereikend om verschillen duidelijk te kunnen herkennen, maar het kan ook zijn dat de winst an kennis en verbetering van de vaardigheden in werkelijkheid minder groot is dan door de huisartsen wordt verondersteld.

De opvallende achteruitgang van de resultaten van een aantal deelnemers is wellicht te verklaren door het bij de voormeting niet gestandaardiseerd afnemen van de toets bij de huisartsen van de controle-toetsgroep en bij twee huisartsen van de onderzoek-toetsgroep. Hoewel vooraf verzocht werd bij de beantwoording van de toets geen gebruik te maken van literatuur, heeft blijkens navraag een aantal van hen niet aan dit verzoek voldaan, met als mogelijk gevolg een hogere score bij de voormeting. De bij de start verkregen hogere gemiddelde score van de controle-toetsgroep zou hierdoor kunnen worden verklaard.

\section{CONCLUSIES}

Meer dan de helft (ongeveer 60\%) van de klachten van gezamenlijke consulten, werd binnen één jaar opnieuw aan de huisarts gepresenteerd. De huisartsen meenden dergelijke patiënten vervolgens beduidend vaker dan voorheen zelf te blijven behandelen. Dit zou volgens de huisartsen vooral als gevolg van kennistoename en verbeterde vaardigheden gebeuren.

$\mathrm{Bij}$ toetsing lijken huisartsen na gezamenlijke consulten voornamelijk op het gebied van vaardigheden iets beter te scoren.

\subsection{Satisfactie van het gezamenlijk consult}

\section{INLEIDING}

De mate waarin huisartsen tevreden zijn over het gezamenlijk consult kan als een graadmeter worden gezien voor deze werkwijze.

Daarom werd aan de huisartsen tijdens de eindconsulten bij patiënten van de interventiegroep gevraagd in hoeverre het gezamenlijk consult aan de verwachtingen had voldaan, terwijl bij patiënten van de controlegroep gevraagd werd in hoeverre zij het betreurden een gezamenlijk consult te hebben gemist. Deze gegevens zijn gerelateerd aan de verwijzingen.

\section{RESULTATEN}

Tabel 4.3.I geeft een hoge (89\%) tevredenheidsscore te zien in de interventiegroep, terwijl in de controlegroep het ontbreken van het gezamenlijk consult bij bijna $40 \%$ van de patiënten niet werd betreurd, en bij $53 \%$ wel. 
Patiënten van de controlegroep bij wie de huisarts het achteraf betreurde dat geen gezamenlijk consult had plaatsgevonden waren opvallend vaak (82\%) verwezen. Wanneer huisartsen niet betreurden dat voor de klacht geen gezamenlijk consult had plaatsgevonden, zagen we een in de controlegroep een opvallend laag (49\%) percentage verwijzingen.

Tabel 4.3.I Mate waarin het gezamenlijk consult aan verwachtingen voldeed of bij ontbreken werd gemist.

\begin{tabular}{|c|c|c|c|c|}
\hline \multirow{2}{*}{ vraag aan huisarts tijdens eindconsult: $\rightarrow$} & \multicolumn{2}{|c|}{$\begin{array}{l}\text { Interventiegroep } n=144 \\
\text { Heeft het gezamenlijk } \\
\text { consult aan uw verwach- } \\
\text { tingen voldaan? }\end{array}$} & \multicolumn{2}{|c|}{$\begin{array}{l}\text { Controlegroep } n=128 \\
\text { Betreurt u nu het ontbre- } \\
\text { ken van het gezamenlijk } \\
\text { consult bij deze patient? }\end{array}$} \\
\hline & $n$ & $\%$ & $n$ & $\%$ \\
\hline $\begin{array}{l}\text { ja } \\
\text { twijfel } \\
\text { nee } \\
\text { niet van toepassing }\end{array}$ & $\begin{array}{r}128 \\
9 \\
7 \\
0\end{array}$ & $\begin{array}{r}89 \\
6 \\
5 \\
0\end{array}$ & $\begin{array}{r}68 \\
7 \\
51 \\
2\end{array}$ & $\begin{array}{r}53 \\
5 \\
40 \\
2\end{array}$ \\
\hline totaal & 144 & 100 & 128 & 100 \\
\hline
\end{tabular}

\section{DISCUSSIE}

Tevredenheid scoorde, conform de verwachtingen en ervaringen uit eerder onderzoek, hoog (ongeveer $90 \%$ ) bij huisartsen wanneer gezamenlijke consulten daadwerkelijk zijn uitgevoerd. (15-19)

Wanneer er door de randomisatie géén gezamenlijk consult volgde (controlegroep), dan werd dit door de huisarts bij ruim de helft van de patiënten achteraf betreurd. Huisartsen betreurden het niet uitvoeren van een gezamenlijk consult vooral wanneer de patiënten waren verwezen. Waarschijnlijk waren de huisartsen van mening, dat bij deze patiënten een aantal verwijzingen voorkomen had kunnen worden, wanneer een gezamenlijk consult zou hebben plaatsgevonden.

Het verschil in 'tevredenheid' tussen beide groepen kan bovendien bevorderd zijn door de verschillende vraagstellingen, waarbij de vraag gesteld over de patiënten van de controlegroep mogelijk vaker een negatief antwoord kan oproepen.

Slechts ten aanzien van een beperkt aantal $(5 \%)$ patiënten van de interventicgroep voldeed het gezamenlijk consult niet aan de verwachtingen van de huisartsen.

\section{CONCLUSIES}

Huisartsen waren doorgaans tevreden over het gezamenlijk consult. Wanneer het niet mogelijk was een geselecteerde patiënt aan het gezamenlijk consult te laten deelnemen (controlegroep-patiënt), betreurde de huisarts dat bij ongeveer $55 \%$ van de patiënten en wel vooral bij hen die gedurende het onderzoeksjaar (zijns inziens wellicht onnodig) werden verwezen. 


\section{Literatuur}

1 Post D. Iatrogene ziekten: een onderzoek van oorsprong en omvang. Stafleu weten. uitg. Alphen a.d. Rijn 1984.

2 Carne S. A problem halved? J Royal Coll Gen Pract 1981;32:10.

3 Knottnerus JA, Joosten J, Daams J. Comparing the quality of referrals of general practitioners with high and average referral rates: an independent panel review. Br J Gen Pract 1990;40:178-81.

4 Paterson JK. Second Opinions. J Royal Coll Gen Pract 1959;2:160-9.

5 Bensing J, Verhaak P. Konsultatieprojekt Eindhoven 3: Verwijspatronen. Utrecht: NHI 1981.

6 Es JC van, Pijlman NR. Het verwijzen van ziekenfondspatiënten in 122 Nederlanse huisartspraktijken. Huisarts Wer 1970;13:433-49.

7 Engelsman C, Geertsema A, Haaijen-Ruskamp FM. De verandering van de gezondheidstoestand en de ongerustheid van de pariënt na een verwijzing. Huisarts Wet 1993; 36(4):128-33.

8 Grundmeyer $\mathrm{H}$, Weert $\mathrm{H}$ van. Patiënt, huisarts en internist: een beschrijvende studie en een kwaliteitsanalyse van verwijzingen naar de internist. Proefschrift Universiteit van Amsterdam 1992.

9 Jongh TOH de, Lentze K. Ongerustheid en het bezoek aan de huisarts. MC 1992; 27/28:853-6.

10 Vierhour WPM, Beusmans GHMI, Verwijnen GM, Ooij A van, Gasselt HRM van, Beek JMH van der. Gezamenlijk Consult huisarts-specialist. MC 1987;4:106-9.

11 Grol R, Zwaard A. Kwaliteits- en deskundigheidsbevordering van huisartsen. Utrecht, NHG publicaties 1990 .

12 Haynes R, Davis D et al. A critical appraisal of the efficacy of continuing medical education. JAMA 1984;25:61-4.

13 Grol R, cs. Deskundigheidsbevordering huisartsen. MC 1993;47:275-8.

14 Schuurman W, Everdingen JJE van, Schadé E. De dermatoloog in de eerste lijn. Huisarts Wet 1992;35(4):161-3.

15 Meyboom WA. Een onderzoek naar (on)tevredenheid over de zorg van huisartsen. MC 1988;20:629-31.

16 Sixma H. Hoe tevreden zijn de mensen over de gezondheidszorg? MC 1988;15:475-6.

17 Have JJIM ten, Kolker L. Consultatievormen Huisarts-Specialist. O en O 1989.

18 Smit DJ de, c.s. Ervaringen met consultatiebijeenkomsten. MC 1990;45:1413-5.

19 Norell LJS. Consultant sessions in health centres and group practices. Community Health $1975 ; 6: 306-10$. 


\section{Informatieoverdracht, verwijsindicaties en behandelingsindicaties, gezien vanuit de specialist}

\section{INLEIDING}

Informatieoverdracht bij verwijzingen is een veel besproken en onderzocht onderwerp. De inhoud van de informatie die door huisartsen wordt overgedragen is sterk wisselend, terwijl ook vaak taakafbakeningsproblemen een rol spelen. (1-3)

Om inzicht te krijgen in de meningen van de orthopaedisch chirurg omtrent het belang van de huisartsgeneeskundige informatie, werd bij iedere patiënt gezien bij het gezamenlijk consult, over de zinvolheid van verkregen informatie een vraag gesteld.

De pilotfase, het peilingsonderzoek en onderzoek met betrekking tot verwijzingen maken aannemelijk, dat in de gebruikelijke Nederlandse gezondheidszorg, huisartsen een belangrijk deel van de verwezen patiënten zelf zouden kunnen behandelen. (4-7)

Omdat we verwachtten dat de groep pariënten, geschikt geacht voor het gezamenlijk consult, voor een groot deel overeenkomt met de groep patiënten die normaliter wordt verwezen, hebben we bij iedere patiënt van het gezamenlijk consult ook over dit onderwerp de mening van de orthopaedisch chirurg gevraagd.

Een derde aandachtspunt betreft de vraag in hoeverre specialistische behandeling na én jaar nog geïndiceerd is. Specialistische behandelingen zijn vaak episodisch van aard.

De gemiddelde duur van de specialistische behandelingen varieert voor de verschillende specialismen. Bovendien zijn binnen het specialisme grote verschillen mogelijk. (6)

Een indicatie van de duur van de behandelingen kan gevonden worden uit het aantal vervolgbehandelingen in verband met de klacht waarvoor is verwezen.

Het percentage vervolgverwijskaarten (verwijskaarten welke na één jaar behandeling verlengd worden voor de duur van één jaar) geeft hierover eveneens informatie. Het aantal vervolgkaarten per 1000 verzekerden verschilt per specialismen en per regio.

Als referentie kan dienen dat in Zuid-Limburg in 1990 het aantal vervolgverwijzingen voor orthopaedische chirurgie $17,1 \%$ bedroeg (gegevens Ziekenfonds Zuid-Limburg). Om na te gaan welk deel van de onderzoekspopulatie langdurig wordt behandeld, en te kunnen zien in hoeverre de onderzoekspopulatie wat dit betreft overeenkomt met patiënten, die doorgaans naar de polikliniek orthopaedie 
verwezen worden, werd aan de orthopaedisch chirurgen tijdens de eindconsulten de vraag gesteld of op dat moment hun inziens specialistische zorg nog geïndiceerd was.

\section{RESULTATEN}

De vraag aan de orthopaedisch chirurgen in hoeverre zij meenden door het gezamenlijk consult betere informatie te ontvangen, werd ten aanzien van $63 \%$ van de patiënten positief beantwoord.

De specialisten waren bovendien van mening dat $65 \%$ van de patiënten aangeboden voor het gezamenlijk consult door de huisartsen zelfstandig zouden zijn te behandelen, hetgeen overeenkomt met eerder onderzoek. (8-10)

Het blijkt dat de orthopaedisch chirurg bij respectievelijk $15,6 \%$ en $13,5 \%$ van de interventie- $(n=144)$ en controlegroeppatiënten $(n=128)$ de specialistische behandeling nog geïndiceerd achtte. Dit wijst erop dat het aantal patiënten dat langdurig behandeld werd, voor beide groepen overeenkomt. De aantallen liggen iets onder de vervolgkaart-gemiddelden $(17,1 \%)$ van de regio. Bij analyse van de diagnose-categorieën van de groep patiënten die na één jaar nog specialistische behandeling zouden behoeven, lijkt $56 \%$ van deze patiënten behandeld te worden vanwege ziektebeelden, waarbij chroniciteit vermoedelijk het geval is (knie-, rugen heupklachten).

\section{DISCUSSIE}

Verbetering van de informatiestroom huisarts-orthopaedisch chirurg kan er toe bijdragen dat de kwaliteit van de behandeling toeneemt. Dit is reeds eerder beschreven en uit eerder onderzoek bekend. $(11,12)$

Ook zal de betere informatie verkregen door het gezamenlijk consult bij individuele patiënten waarschijnlijk meer in het algemeen de kennis van orthopaedisch chirurgen over de huisartsgeneeskundige benadering en behandelwijze ten goede komen. Dit zou mogelijk belangrijke winst op kunnen leveren omdat bekend is dat het specialisten vaak ontbreekt aan inzicht in het werk van de huisartsen. (13-16)

Waar uit de resultaten blijkt dat de orthopaedisch chirurgen bij het gezamenlijk consult menen dat ongeveer $2 / 3$ deel van de aangeboden patiënten vervolgens door huisartsen zelfstandig kan worden behandeld, komt dit overeen met het percentage verwijzingen (35\%) in de interventiegroep tijdens het onderzoeksjaar. Deze bevinding sluit aan bij de conclusie van Mokkink die het verwijzen bij 'selflimiting' aandoeningen vaststelde en met die van Felson c.s. die concludeerde dat het merendeel van klachten van het bewegingsapparaat door huisartsen te behandelen zou zijn. $(5,17,18)$

Wel moet opgemerkt worden dat aan de orthopaedisch chirurgen niet gevraagd is in hoeverre een gezamenlijk consult een noodzakelijke voorwaarde werd geacht, teneinde een aantal patiënten zelfstandig te doen behandelen door de huisarts. Als het aantal wenselijk geachte vervolgbehandelingen (ongeveer 15\%) wordt gezien als een resultaat van de behandeling, verschillen interventie- en controlegroep hieromtrent nauwelijks van elkaar. 
Het aantal vervolgbehandelingen na één jaar verschilt ook tussen de onderzoekspopulatie en de polikliniekpopulatie vrijwel niet.

De groep patiënten waarvoor in de onderzoekspopulatie een voortzetting van de behandeling noodzakelijk wordt geacht, lijkt voor een groot deel te bestaan uit patiënten met veelal chronische en/of ernstige lichamelijke klachten van het bewegingsapparaat.

Patiënten met chronische en/of ernstige klachten van het bewegingsapparaat zijn waarschijnlijk zowel in de groep patiënten voor het gezamenlijk consult als in de 'polikliniekgroep' vrijwel in dezelfde percentages aanwezig.

\section{CONCLUSIES}

Orthopaedisch chirurgen ontvingen bij $2 / 3$ deel van de voor het gezamenlijk consult geselecteerde patiënten naar hun mening betere informatie dan bij de gebruikelijke zorg. Zij meenden dat bij $1 / 3$ deel van deze voor het gezamenlijk consult geselecteerde patiënten een verwijzing geïndiceerd was. Specialistische behandeling na één jaar leek de orthopaeden nog bij ongeveer $15 \%$ van de patiënten gewenst.

\section{Literatuur}

1 Post D. Verwijzen en prescriptie, een paar apart. Zwolle: Regionaal Ziekenfonds Zwolle 1984.

2 Long A, Atkins JB. Communications between General Practitioners and consultants. $\mathrm{Br}$ Med J 1974;4:456-9.

3 Swinkels MAA, Dopheide JP. Samenwerking tussen $1^{\circ}-2^{\circ}$ lijnsgezondheidszorg te Hoogeveen, Utrecht NHI 1982.

4 Vierhout WPM, Beusmans GHMI, Verwijnen GM, Ooij A van, Gasselt HRM van, Beek JMH van der. Gezamenlijk Consult huisarts-specialist. MC 1987;4:106-9.

5 Felson DT, Meenan RF, Dayno SF, Gertman P. Referral of musculoskeletal disease patients by family en general practitioners. Arthritis-Rheumat 1985;28(10):1156-62.

6 Meyboom-Jong de B. De oudere patiënt in beeld. Huisarts Wet 1991;34(2):82-8.

7 Marinker M, Wilkin D, Mercalfe DH. Referral to hospital: can we do better? Br Med J 1988;297(6646):461-4.

8 Meer K van der, Smith RJA. Patiënten met chronisch klaaggedrag in de huisartspraktijk. Huisarts Wet 1991;35(1):13-7.

9 Carne S. A problem halved? J Royal Coll Gen Pract 1981;32:10.

10 Paterson JK. Second Opinions. J Royal Coll Gen Pract 1959;2:160-9.

11 Starfield B, Steinwachs D et al. Concordance between Medical Records and Observations Regarding Information on Coordination of Care. Med Care 1979;17:758-66.

12 Verhaak PFM. Hoe speciaal is de communicatie van de huisarts? Huisarts Wet 1991; $34(7): 320-4$.

13 Jacobs HM, Melker RA de, Hell RJ van der. Wat weten specialisten van het werk van huisartsen? Huisarts Wet 1990;33(4):152-6.

14 Geertsma A, Engelsman C, Haayer-Ruskamp FM. Overeenstemming van specialistische zorg en bedioeling van de huisarts bij verwijzing van pariënten. Ned Tijdschr Geneeskd 1992;136(23):1107-10. 
15 Voort HJPM van der. Beeldvorming in de relatie huisarts-specialist. Huisarts Wet 1975;18:420-5.

16 Ooij A van, Walenkamp GHIM, Geesink RGT, Arens HJ, Vierhout WPM, Knottnerus JA. Consultatie in de huisartspraktijk; een specialistische impressie. MC 1992;4:118-20.

17 Mokkink HGA. Ziekenfondscijfers als paramerer over her handelen van huisartsen. Proefschrift Nijmegen KUN 1986.

18 Lisdonk EH van de. Ervaren en aangeboden morbiditeit in de huisartsprakrijk: een onderzoek met dagboeken. Proefschrift Nijmegen KUN 1985. 


\section{Haalbaarheid van het gezamenlijk consult}

\section{INLEIDING}

Voor de haalbaarheid van de gezamenlijke consultspreekuren moet aan een aantal voorwaarden worden voldaan. Vooraf zal tussen huisartsen en specialisten overeenstemming moeten bestaan over de werkwijze. Er moeten afspraken worden gemaakt over de praktische uitvoering, de verantwoordelijkheid naar de patiënt en de honorering.

De daadwerkelijke uitvoering van het effectiviteitsonderzoek gaf nadere informatie over de concrete behoefte aan een gezamenlijk consult en over de praktische uitvoerbaarheid voor patiënten, huisartsen en specialisten.

Om in breder verband inzicht te krijgen over de behoefte bij huisartsen en orthopaedisch chirurgen aan gezamenlijke consulten is een peilingsonderzoek verricht bij de huisartsen van de regio Heuvelland. Ook zijn van de orthopaedisch chirurgen in Limburg en Oost-Brabant de opinies ten aanzien van het gezamenlijk consult geïnventariseerd. (Zie hoofdstuk 7).

Het onderzoek naar de uitvoerbaarheid van het gezamenlijk consult (het effectiviteitsonderzoek) wordt beschreven in paragraaf 6.1., het peilingsonderzoek in paragraaf 6.2.

\subsection{Uitvoerbaarheid van gezamenlijk consultspreekuren}

\section{INLEIDING}

Zowel op het moment dat huisartsen en specialisten beslissen om het gezamenlijk consult te starten (bij de bespreking van de voorwaarden), als tijdens het verloop, spelen een aantal factoren een rol, die gevolgen kunnen hebben voor de uitvoerbaarheid. Het verdient aanbeveling hiermee bij de voorbereiding zoveel mogelijk rekening te houden.

De 5-tal factoren, deels bekend vanuit eerder onderzoek en vanuit pilot-study ervaringen, welke de uitvoerbaarheid beïnvloeden, betreffen 'motivatie', 'gezamenlijk bespreken', 'vreemde spreekkamer', 'tijdsbelasting' en 'nascholingseffect'. (1-4) $\mathrm{Zij}$ worden hieronder beschreven.

- De motivatie van huisarts en specialist.

Het is een noodzakelijke voorwaarde, dat huisartsen en specialisten die deelnemen, goed gemotiveerd zijn. (5-9) 
Mede vanuit de eerdere ervaringen (pilot-study) waren de orthopaedisch chirurgen van het AZM gemotiveerd om deel te nemen. (Zie verder ervaringen orthopaedisch chirurgen, hoofdstuk 7).

De huisartsen uit de regio toonden ruim voldoende belangstelling. Omdat slechts twaalf huisartsen aan het onderzoeksproject zouden kunnen deelnemen (zie paragraaf 2.3.) moesten we een aantal huisartsen van deelname uitsluiten.

\section{- Gezamenlijke patiëntenbespreking.}

De meeste huisartsen zijn in hun praktijkvoering niet gewend aan patiëntenbesprekingen met collegae, waarbij probleemsituaties van patiënten expliciet worden getoond en besproken. (6,7)

Daarom hebben we voorafgaand aan de start van het onderzoeksproject gedurende enkele maanden 'proefgedraaid', door een aantal gezamenlijke consultspreekuren uit te voeren zonder onderzoeksgegevens te verzamelen.

\section{- 'Vreemde' spreekkamer en benadering door 'groep artsen'.}

Uit organisatorisch oogpunt werden de gezamenlijke consultspreekuren voor de solisten steeds in hetzelfde praktijkpand gepland.

Dit betekende dat een aantal huisartsen met hun patiënten in een voor hen vreemde spreekkamer kwam.

Wanneer in de toekomst huisartsen de mogelijkheid geboden zou worden achtereenvolgens voor andere specialistische vakgebieden gezamenlijk consultspreekuren uit te voeren, zou de plaats waar de gezamenlijke consultspreekuren plaatsvinden per specialisme kunnen wisselen.

Bovendien worden de patiënten tijdens een gezamenlijk consult door een groep bestaande uit vier artsen ( 3 huisartsen en 1 orthopaedisch chirurg) tegemoet getreden, hetgeen de privacy en intimiteit niet ten goede komt.

Beide factoren zouden de motivatie van de huisartsen en patiënten negatief kunnen beïnvloeden en daardoor de haalbaarheid.

- Tijdsbelasting, verstoring door spoedgevallen, praktijkorganisatie.

Tijdsbelasting, spoedgevallen, vakantieregelingen en dergelijke kunnen een regelmatige uitvoering van gezamenlijke spreekuren verstoren.

\section{- Het nascholingseffect.}

Te verwachten is, dat gezamenlijke consulten zoals eerder beschreven een nascholingseffect oplevert, hetgeen voor huisartsen een motief kan zijn om deel te nemen.

Het nascholingseffect zal van invloed kunnen zijn op het patiëntenaanbod voor de gezamenlijke consulten. Het is immers denkbaar, dat huisartsen met de kennis en ervaring daardoor opgedaan, patiënten met identieke problemen vervolgens zelfstandig behandelen, waardoor het patiëntenaanbod voor gezamenlijke consulten vervolgens kan dalen. (Zie hoofdstuk 4) 
Tegen de beschreven achtergrond zijn met betrekking tot de haalbaarheid van de gezamenlijke consultspreekuren de volgende drie vragen gesteld:

- Is voor patiënten, huisartsen en orthopaedisch chirurgen de organisatie haalbaar en uitvoerbaar?

(Hoe vaak zijn geplande gezamenlijke consultspreekuren uitgevallen en welke waren de motieven?).

- Welke is de behoefte bij huisartsen voor klachten van het bewegingsapparaat, en bestaan er verschillen tussen verschillende groepen huisartsen?

- Hoe verloopt de behoefte bij huisartsen, die regelmatig deelnemen aan gezamenlijke consultspreekuren?

(Hoe verloopt het patiëntenaanbod tijdens het effectiviteitsonderzoek?).

\section{METHODE}

Om geïnformeerd te worden over de haalbaarheid van gezamenlijke consultspreekuren hebben we de gegevens verzameld over de instroom van patiënten, terwijl bovendien huisartsen en orthopaedisch chirurgen vragen werden gesteld over de uitval van spreekuren en de bijbehorende redenen.

Voor het effectiviteitsonderzoek gingen we, gezien de ervaringen van het pilotonderzoek, uit van een behoefte aan gezamenlijke consultspreekuren van éénmaal per twee tot drie weken per huisartsengroep. Tijdens een spreekuur zouden ongeveer vier patiënten kunnen worden gezien.

\section{RESULTATEN}

In de periode van 1 april 1989 tot 1 januari 1991 zijn de spreekuren vrijwel steeds volgens plan verlopen.

In totaal zijn er vier spreekuren uitgevallen, om de volgende redenen:

geen patiënten:

verkeerde afspraak:

organisatorische reden:
2 maal

1 maal

1 maal

De werkelijke uitval (door praktische problemen) bedroeg dientengevolge twee spreekuren. Op een totaal van 52 gezamenlijk consultspreekuren betekende dit een uitval van $4 \%$.

Uitval tengevolge van onvoorziene omstandigheden, spoedsituaties en dergelijke, deed zich niet voor.

De figuren 6.1.I en II laten de instroom zien voor de interventie- en controlegroep, respectievelijk in totaal en ingedeeld naar huisartsengroep.

De daling in het derde kwartaal van 1989 en van 1990 werd voor een belangrijk deel veroorzaakt door vakantieperioden.

We zien tot en met het tweede kwartaal in 1990 een redelijk constant patiëntenaanbod. Vanaf het derde kwartaal van 1990 was er een duidelijke afname.

Voor de onderscheiden huisartsgroepen zijn identieke patronen te zien. 
Figuur 6.1.I Instroom patiënten gezamenlijk consult, weergegeven per kwartaal.

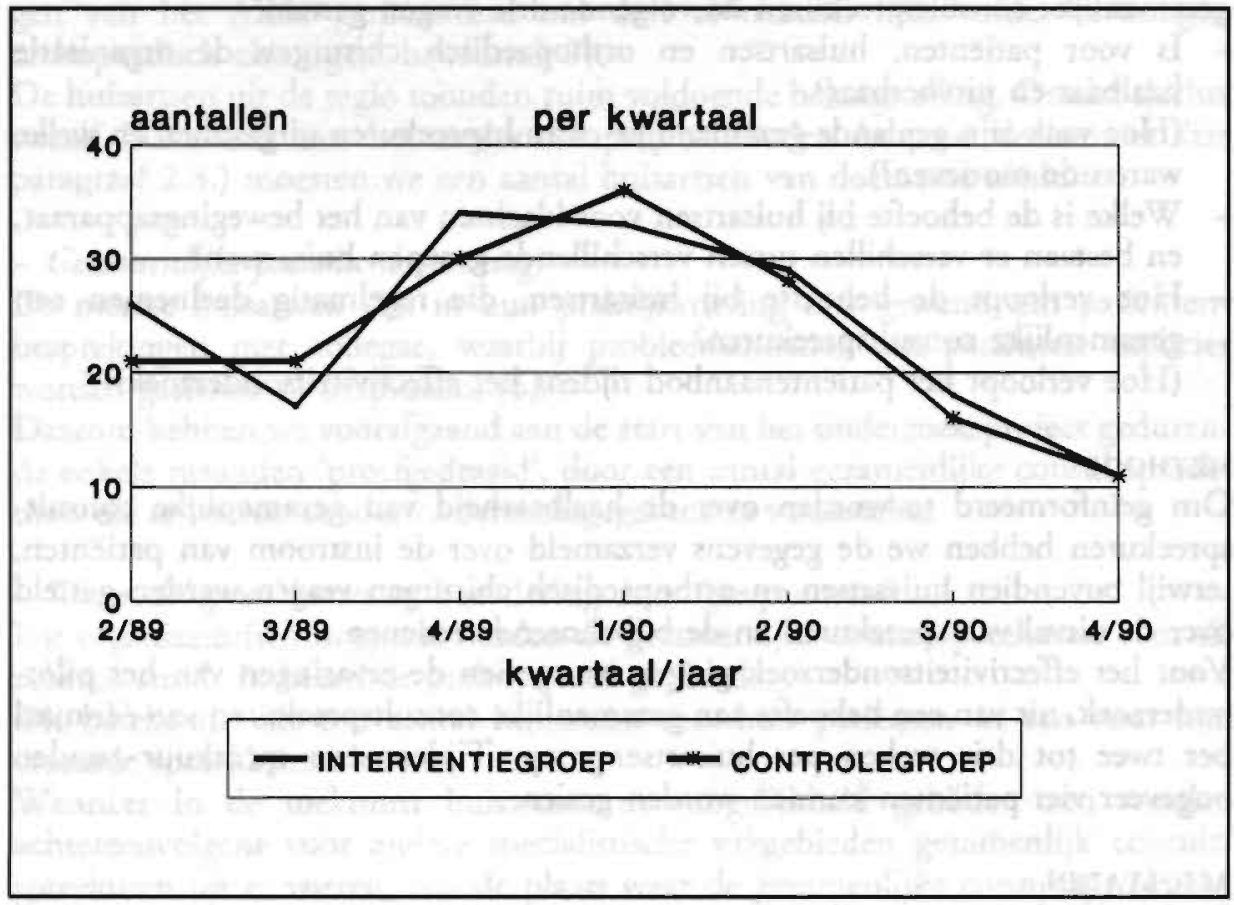

Tijdens het project werden in totaal 339 patiënten door hun huisartsen geschikt geacht voor een gezamenlijk consult.

In groep I is zoals eerder vermeld vanwege een mutatie van een van de huisartsen enige tijd stagnatie opgetreden in de patiënteninstroom.

In groep II leverde één van de huisartsen enkele maanden na de start van het project geen patiënten meer voor een gezamenlijk consult, vanwege de bij het onderzoek behorende administratieve werkzaamheden (indeling huisartsgroepen paragraaf 2.3). 
Figuur 6.1.II Instroom patiënten gezamenlijk consult, weergegeven per huisartsgroep.

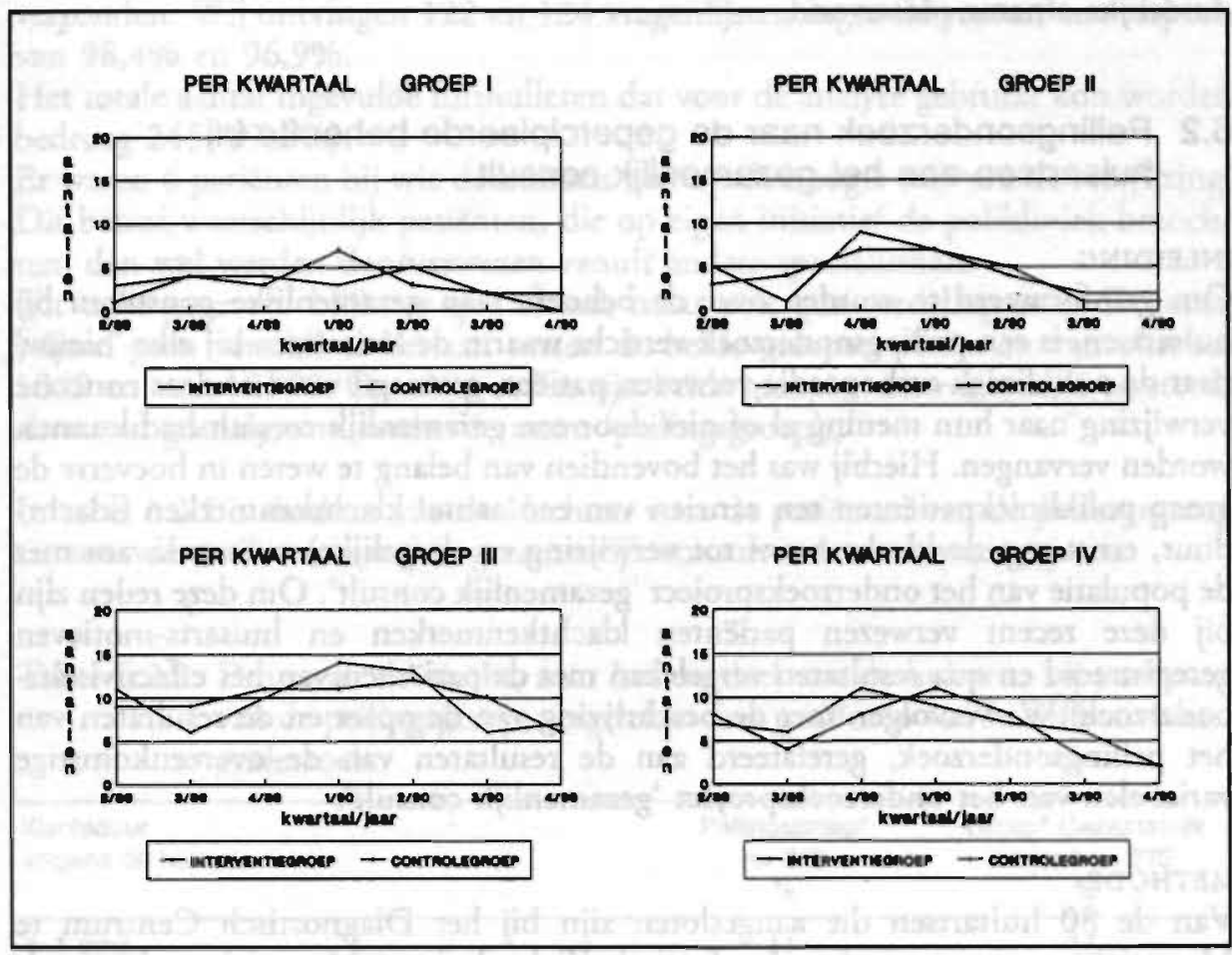

\section{DISCUSSIE}

De geringe uitval van de gezamenlijke consultspreekuren betekent dat de gezamenlijke consulten organisatorisch goed haalbaar zijn.

Wellicht hebben de planning van proefspreekuren, de motivatie van de deelnemers en de goede sfeer in de groepen hierbij een belangrijke rol gespeeld.

Uit het verloop van het patiëntenaanbod valt af te leiden, dat de behoefte aan gezamenlijke consultspreekuren na ongeveer anderhalf jaar duidelijk afneemt.

Dit gegeven geldt voor alle huisartsgroepen, ook al verschilt het gemiddelde aanbod per huisartsgroep.

De dalende behoefte zal voor een belangrijk deel het gevolg zijn van de door de huisartsen ervaren effecten als gevolg van de deskundigheidsbevordering, ontstaan tijdens de voorgaande gezamenlijke consulten (zie ook paragraaf 4.2.).

\section{CONCLUSIES}

De gezamenlijke consultspreekuren waren gedurende anderhalf jaar goed haalbaar. Er was voldoende patiëntenaanbod en geen belangrijke uitval door organisatorische redenen. 
Het patiëntenaanbod varieerde per huisarts en huisartsengroep maar vertoonde over anderhalf jaar een vrij constant patroon, waarbij tegen het einde een duidelijke afname plaatsvond.

\subsection{Peilingsonderzoek naar de gepercipieerde behoefte bij huisartsen aan het gezamenlijk consult}

\section{INLEIDING}

Om geïnformeerd te worden over de behoefte aan gezamenlijke consulten bij huisartsen, is een peilingsonderzoek verricht waarin de huisartsen bij elke 'nieuw' naar de polikliniek orthopaedie verwezen patiënt, gevraagd werd of deze concrete verwijzing naar hun mening al of niet door een gezamenlijk consult had kunnen worden vervangen. Hierbij was het bovendien van belang te weten in hoeverre de groep polikliniekpatiënten ten aanzien van een aantal klachtkenmerken (klachtduur, ernst van de klacht, wens tot verwijzing en dergelijke) overeenkwam met de populatie van het onderzoeksproject 'gezamenlijk consult'. Om deze reden zijn bij deze recent verwezen patiënten klachtkenmerken en huisarts-motieven geregistreerd en qua resultaten vergeleken met de patiënten van het effectiviteitsonderzoek. We vervolgen met de beschrijving van de opzet en de resultaten van het peilingsonderzoek, gerelateerd aan de resultaten van de overeenkomstige variabelen van het onderzoeksproject 'gezamenlijk consult'.

\section{METHODE}

Van de 80 huisartsen die aangesloten zijn bij het Diagnostisch Centrum te Maastricht en voor wie het Academisch Ziekenhuis te Maastricht primair als streekziekenhuis fungeert, werden 66 huisartsen (de huisartsen van het project gezamenlijk consult werden uiteraard niet benaderd) geïnformeerd en verzocht (zie bijlage 15) deel te nemen aan het schriftelijk peilingsonderzoek; 64 reageerden er positief. $\mathrm{Zij}$ ontvingen informatie over de aard en de inrichting van het gezamenlijk consult. (5-9)

Het peilingsonderzoek werd gedurende 2 perioden van 4 weken (november 1989 en maart 1990) uitgevoerd. Via het afsprakenbureau van de polikliniek orthopaedie werden dagelijks de gegevens van alle nieuw-verwezen patiënten verzameld. De huisarts ontving vervolgens, uiterlijk binnen 3 dagen en per onderzoeksperiode maximaal 4 maal, een vragenformulier (zie bijlage 16) betreffende de verwezen patiënt: gevraagd werd naar duur, hinder en mate van bezorgheid met betrekking tot de klacht (= klachtkenmerken).

De vragenlijst bevatte bovendien een aantal vragen naar factoren waarvan werd verwacht dat zij een rol zouden spelen in het proces van verwijzen (verzoek van patiënt om verwijzing, motieven tot verwijzing), alsmede de vraag of bij deze verwezen patiënt, indien mogelijk, een gezamenlijk consult wenselijk zou zijn geweest. Ook uit het gegevensbestand van het effectiviteitsonderzoek werden de antwoorden op deze vragen betrokken, om de groepen patiënten te kunnen vergelijken. 


\section{RESULTATEN}

In de twee peilingsperioden werden respectievelijk 124 en 128 vragenlijsten verzonden. Wij ontvingen 122 en 124 vragenlijsten ingevuld retour; een respons van $98,4 \%$ en $96,9 \%$.

Het totale aantal ingevulde formulieren dat voor de analyse gebruikt kon worden bedroeg $245(97,2 \%)$.

Er waren 6 patiënten bij wie de huisarts niet op de hoogte was van de verwijzing. Dit betrof waarschijnlijk patiënten, die op eigen initiatief de polikliniek bezochten, dan wel werden doorverwezen vanuit andere specialismen.

Uit onze gegevens blijkt er qua aantal, maar ook qua verdeling over de items, vrijwel geen verschil te bestaan tussen de beide groepen patiënten van oktober 1989 en maart 1990. Om deze reden zijn beide groepen samengevoegd en steeds als totaal geanalyseerd onder de naam 'peilingsgroep'.

In tabel 6.2.I is de duur van de klachten voor de patiënten van de peilingsgroep en voor de patiënten van het gezamenlijk consultonderzoek weergegeven.

Tabel 6.2.I Duur van de klacht, naar het oordeel van de huisarts, bij patiënten van de peilingsgroep, vergeleken met patiënten van het effectiviteitsonderzoek.

\begin{tabular}{lcc}
\hline $\begin{array}{l}\text { Klachtduur } \\
\text { volgens de huisarts }\end{array}$ & $\begin{array}{c}\text { Peilingsgroep** } \\
n=245 \\
\%\end{array}$ & $\begin{array}{c}\text { Groep* Gezamenlijk } \\
\text { consult } n=272 \\
\%\end{array}$ \\
\hline$<1$ mnd & 11 & 17 \\
$1-5$ mnd & 39 & 43 \\
$6-12$ mnd & 15 & 14 \\
21 jaar & 35 & 26 \\
totaal & 100 & 100 \\
\hline
\end{tabular}

Chi-kwadraattoets $p=0.09$

Als we de groepen met elkaar vergelijken, blijken er geen significante verschillen te zijn, hoewel de klachten van de gezamenlijke consultgroep over het geheel iets korter aanwezig waren.

De klachten bestonden voor respectievelijk $89 \%$ en $83 \%$ van de patiënten langer dan 1 maand.

Bij de helft van de patiënten van de peilingsgroep waren de klachten langer dan een half jaar aanwezig. Bij de groep patiënten van het gezamenlijk consultprojekt was dat voor $40 \%$ van de patiënten het geval.

In tabel 6.2.II is de mate van door de huisartsen gepercipieerde last of hinder naar aanleiding van de klachten weergegeven. 
Tabel 6.2.II Hinder naar aanleiding van de klacht, naar het oordeel van de huisarts, bij patiënten van de peilingsgroep, vergeleken met patiënten van het effectiviteitsonderzoek.

\begin{tabular}{lcc}
\hline $\begin{array}{l}\text { Mate van hinder } \\
\text { volgens de huisarts }\end{array}$ & $\begin{array}{c}\text { Pellingsgroep* } \\
n=245 \\
\%\end{array}$ & $\begin{array}{c}\text { Groep* Gezamenlijk } \\
\text { consult } n=272 \\
\%\end{array}$ \\
\hline zeer veel & 22 & 7 \\
veel & 58 & 52 \\
matig & 19 & 37 \\
weinig & 1 & 3 \\
geen & 0 & 1 \\
totaal & 100 & 100 \\
\hline
\end{tabular}

Chl-kwadraattoets $p=<.01$

De huisartsen van de peilingsgroep percipieerden de mate van hinder ten aanzien van de klacht significant hoger dan de huisartsen deden voor hun patiënten uit het onderzoeksproject 'gezamenlijk consult'. De huisartsen van de peilingsgroep schatten de mate van hinder voor $80 \%$ van de patiënten als 'zeer veel' of 'veel'. Voor de patiënten van het gezamenlijk consultproject was dit bij $59 \%$ van de patiënten het geval.

In tabel 6.2.III zien we de resultaten van de vragen naar de mate van bezorgheid welke omtrent de klacht door de huisartsen wordt gepercipieerd.

Tabel 6.2.III Bezorgheid over de klacht, naar het oordeel van de huisarts, bij patiënten van de peilingsgroep, vergeleken met patiënten van het effectiviteitsonderzoek.

\begin{tabular}{lcc}
\hline $\begin{array}{l}\text { Bezorgatheid over de klacht } \\
\text { volgens de huisarts }\end{array}$ & $\begin{array}{c}\text { Peilingsgroep* } \\
n=245\end{array}$ & $\begin{array}{c}\text { Groep* Gezamenlijk } \\
\text { consult } n=272 \\
\%\end{array}$ \\
\hline zeer veel & $\%$ & 11 \\
veel & 11 & 39 \\
matig & 38 & 35 \\
weinig & 32 & 9 \\
geen & 13 & 6 \\
loteal & 6 & 100 \\
\hline
\end{tabular}

Chi-kwadraattoets $p=0.64$

Hier zien we dat de huisartsen van de peilingsgroep de bezorgheid over de klacht vrijwel even hoog inschatten als hun collegae deden voor de patiënten van het onderzoeksproject. 
Tabel 6.2.IV laat zien in welke mate er een wens tot verwijzing in relatie tot de klacht aanwezig was.

Tabel 6.2.IV Percentage patiënten dat, naar het oordeel van de huisarts, in beide groepen verzocht om verwijzing naar specialist.

\begin{tabular}{lcc}
\hline Verzoek om verwijzing volgens de huisarts & $\begin{array}{c}\text { Peilingsgroep* } \\
n=245\end{array}$ & $\begin{array}{c}\text { Groep* Gezamenlijk } \\
\text { consult } n=272 \\
\%\end{array}$ \\
\hline ja & $\%$ & 39 \\
nee & 37 & 61 \\
totaal & 63 & 100 \\
\hline
\end{tabular}

Chi-kwadraattoets $p=0.64$

De percentages van de peilingsgroep zijn vrijwel gelijk aan die van het onderzoeksproject.

In tabel 6.2.V wordt aangegeven waarom de patiënten van de peilingsgroep volgens hun huisartsen werden verwezen.

Tabel 6.2.V Motieven tot verwijzing, naar het oordeel van de huisarts, bij patiënten van de peilingsgroep.

(meer motieven per patiënt mogelijk)

Peilingsgroep $n=245$

1. geen duidelijke diagnose

2. second opinion 24.1

3. emstige pathologie

4. acuut probleem

5. geen therepeutisch plan

6. plan niet uitvoerbaar door huisarts

7. orthopaed meest adequate behandelaar

8. anders:

- ter geruststelling

- verzekeringstechnische reden

- geen verbetering na eerdere therapie

- diverse andere redenen

Diverse motieven tot verwijzing konden gelijktijdig aanwezig zijn.

De aantallen motieven tot verwijzing worden per item gerelateerd aan het totaal van 245 patiënten $(=100 \%)$. Doordat per patiënt meer dan één motief aanwezig kan zijn bedraagt het totaal meer dan $100 \%$ (141\%). 
Voor de iterns 1,2 en 5 kan een gezamenlijk consult zinvol zijn, terwijl voor de items 6 en 7 een verwijzing noodzakelijk lijkt te zijn.

Speciale aandacht vraagt het item nr.8 (=anders) dat bij 48 patiënten werd ingevuld. De opmerkingen bij dit item zijn in hoofdzaak te rubriceren in drie categorieën, te weten: ter geruststelling of op verzoek van patiënt, verzekeringstechnische redenen (b.v. verlenging machtiging, maatschoeisel, Ziektewetproblematiek) en geen verbetering na voorgaande therapie (= vaak fysiotherapie.)

In tabel 6.2.VI staan de resultaten vermeld over de wenselijkheid van een gezamenlijk consult, zoals gepercipieerd door de huisartsen bij de patiënten van de peilingsgroep.

Tabel 6.2.VI Peilingsgroep: mate waarin de huisartsen bij deze verwijzingen gebruik zouden willen maken van een gezamenlijk consult.

\begin{tabular}{lrr}
\hline & \multicolumn{2}{c}{ Peilingsgroep $n=245$} \\
\cline { 2 - 3 } & \multicolumn{1}{c}{$n$} & \multicolumn{1}{c}{$\%$} \\
\hline ja, gezamenlijk consult & 128 & 52 \\
nee, geen gezamenlijk consull & 103 & 42 \\
anders & 2 & 1 \\
weet nlet & 12 & 5 \\
totaal & 245 & 100 \\
\hline
\end{tabular}

Volgens de huisartsen zou bij meer dan de helft van de verwijzingen een gezamenlijk consult gewenst zijn geweest.

Wanneer we de twee groepen patiënten (wel of niet gezamenlijk consult wenselijk) relateren aan de klachtkenmerken en de vraag om verwijzing, zien we weinig verschillen tussen beide groepen (tabel 6.2.VII-X).

Tabel 6.2.VII 'Klachtduur' in relatie tot 'wens gezamenlijk consult' (na verdeling van de peilingsgroep in twee groepen naar gelang de huisarts bij verwijzing een gezamenlijk consult wenst).

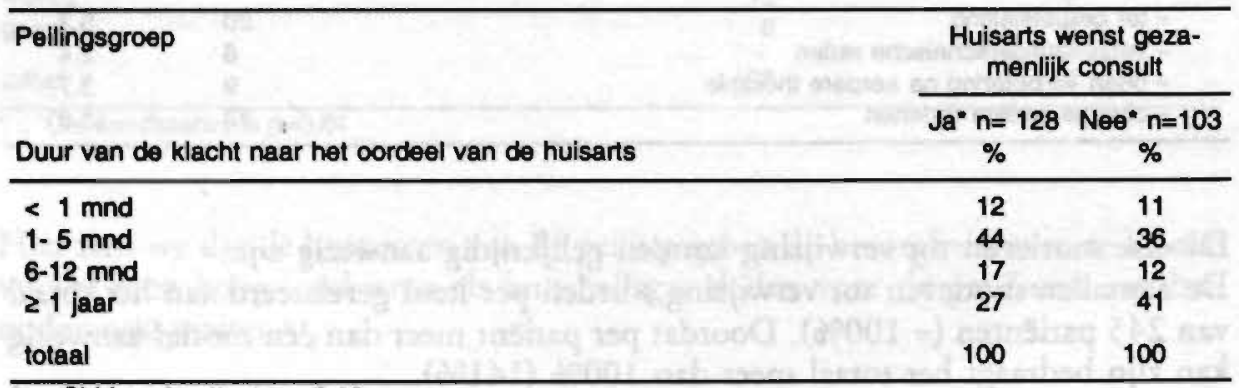

Chi-kwadraattoets $p=0.19$ 
Tabel 6.2.VII 'Hinder' in relatie tot 'wens gezamenlijk consult' (na verdeling van de peilingsgroep in twee groepen naar gelang de huisarts bij verwijzing een gezamenlijk consult wenst).

\begin{tabular}{lcc}
\hline Peilingsgroep & \multicolumn{2}{c}{$\begin{array}{c}\text { Huisarts wenst gezamen- } \\
\text { lijk consult }\end{array}$} \\
\cline { 2 - 3 } & $\begin{array}{c}\text { Ja* } n=128 \\
\%\end{array}$ & $\begin{array}{c}\text { Nee* } n=101 \\
\%\end{array}$ \\
\hline Hinder door de klacht naar het oordeel van de huisarts & 18 & 29 \\
veer veel & 59 & 54 \\
matig & 20 & 17 \\
weinig & 2 & 0 \\
geen & 1 & 0 \\
totaal & 100 & 100 \\
\hline
\end{tabular}

Tabel 6.2.IX 'Bezorgheid' in relatie tot 'wens gezamenlijk consult' (na verdeling van de peilingsgroep in twee groepen naar gelang de huisarts bij verwijzing een gezamenlijk consult wenst).

\begin{tabular}{|c|c|c|}
\hline \multirow{2}{*}{$\begin{array}{l}\text { Peilingsgroep } \\
\text { Bezorgdheid over de klacht naar het cordeel van de huisarts }\end{array}$} & \multicolumn{2}{|c|}{$\begin{array}{l}\text { Huisarts wenst gezamen- } \\
\text { lijk consult }\end{array}$} \\
\hline & $\begin{array}{c}\mathrm{Ja}^{*} \mathrm{n}=128 \\
\%\end{array}$ & $\begin{array}{c}\text { Nee } n=101 \\
\%\end{array}$ \\
\hline $\begin{array}{l}\text { zeer veel } \\
\text { veel } \\
\text { matig } \\
\text { weinig } \\
\text { geen }\end{array}$ & $\begin{array}{r}11 \\
38 \\
35 \\
12 \\
4\end{array}$ & $\begin{array}{l}10 \\
39 \\
26 \\
15 \\
10\end{array}$ \\
\hline totaal & 100 & 100 \\
\hline
\end{tabular}

Tabel 6.2.X 'Verzoek om verwijzing' in relatie tot 'wens gezamenlijk consult' (na verdeling van de peilingsgroep in twee groepen naar gelang de huisarts bij verwijzing een gezamenlijk consult wenst).

\section{Peilingsgroep}

Verzoek om verwijzing volgens het oordeel van de huisarts

\begin{tabular}{|c|c|c|}
\hline \multirow[b]{2}{*}{ Verzoek om verwijzing volgens het oordeel van de huisarts } & \\
\hline & $\begin{array}{c}\mathrm{Ja}^{*} \mathrm{n=128} \\
\%\end{array}$ & $\begin{array}{c}\text { Nee" } n=100 \\
\%\end{array}$ \\
\hline $\begin{array}{l}\text { ja } \\
\text { nee } \\
\text { anders } \\
\text { weet niet }\end{array}$ & $\begin{array}{r}34 \\
52 \\
6 \\
8\end{array}$ & $\begin{array}{r}42 \\
52 \\
5 \\
1\end{array}$ \\
\hline totaal & 100 & 100 \\
\hline
\end{tabular}

Huisarts wenst gezamen-

lijk consult

\footnotetext{
Chi-kwadraattoets $p=0.10$
} 
Vervolgens hebben we de groepen waarbij de huisartsen al of niet een gezamenlijk consult wensten, uitgezet tegen de motieven die de huisartsen aangaven voor de verwijzing (tabel 6.2.XI). Per patiënt kon meer dan éen reden worden aangegeven.

Tabel 6.2.XI Verdeling van de peilingsgroep in twee groepen naar gelang de huisarts bij verwijzing een gezamenlijk consult wenst. (meer dan één motief per patiënt mogelijk)

Peilingsgroep

Molieven van huisarts bij verwijzing

Huisarts wenst geza-

menlijk consult

1. geen duidelijke diagnose

Ja $n=128$ Nee $n=104$

2. wilde een second opinion

$39 \quad 15$

3. verwacht emstige pathologie

4. acuut probleem

5. geen therapeutisch plan

24

plan niet uitvoertar door

r huisarts

7. orthopaed meest adequate behandelaar

8. anders:

- ter geruststelling

- verzekeringstechnische redenen

- geen verbetering na eerdere therapie

- diverse andere redenen

De behoefte aan een gezamenlijk consult laat, vergeleken met het niet aanwezig zijn van deze behoefte, vooral verschillen zien bij de motieven: 'geen duidelijke diagnose', 'second opinion', 'geen therapeutisch plan', 'geen verbetering na eerdere therapie' en 'plan niet uitvoerbaar door huisarts'.

Wanneer werd aangegeven dat de orthopaedisch chirurg de meest adequate behandelaar is, werd vaak toch nog een gezamenlijk consult gewenst (35 van de 75 keer).

DISCUSSIE

Uit dit onderzoek komt naar voren dat een peiling naar meningen en motieven van huisartsen over patiënten die recent werden verwezen, goed uitvoerbaar is. Wellicht zijn de accurate en vrijwel volledige deelname van de huisartsen uit de regio en de hoge respons te verklaren uit het feit dat het Diagnostisch Centrum een goede naam in de regio heeft verworven en als iets van de huisartsen zelf wordt gezien.

Daarbij komt dat het onderwerp van het peilingsonderzoek door de huisartsen wordt gewaardeerd en streeft de afdeling Orthopaedie daadwerkelijk een goede samenwerking met de huisartsen na.

Behoudens het feit dat de aan het onderzoek deelnemende huisartsen ervaring opdoen met het gezamenlijk consult en de overige huisartsen uitsluitend door 
middel van een brief hierover informatie ontvingen, zijn er verder geen redenen waardoor de aan het peilingsonderzoek deelnemende huisartsen op voor het onderzoek relevante items zouden verschillen van de huisartsen die deelnamen aan het effectiviteitsonderzoek. $\mathrm{Zij}$ wijken qua gemiddelde verwijscijfers, praktijksituaties, praktijkervaring en de patiëntenpopulatie niet af van de huisartsen die aan het peilingsonderzoek deelnamen.

Er werd slechts een gering aantal (6) patiënten buiten medeweten van de huisarts naar de polikliniek 'nieuw' verwezen. Dit betekent dat het 'nieuw' verwijzen naar de polikliniek op het gebied van de orthopaedie vrijwel geheel door de huisarts werd uitgevoerd.

Wij veronderstelden dat patiënten voor wie de huisarts een gezamenlijk consult wenst, bij het ontbreken van die mogelijkheid vaak vroeger of later zullen worden verwezen. Conform onze verwachtingen blijkt bij vergelijking, dat de patiënten van de peilingsgroep op het gebied van klachtduur, bezorgdheid en wens om verwijzing in belangrijke mate overeenkomen met de patiënten van het effectiviteitsonderzoek.

Bedacht moet worden, dat de groep patiënten voor het gezamenlijk consult waarschijnlijk niet volledig identiek zal zijn aan de groep patiënten voor de polikliniek, omdat voor het gezamenlijk consult uitsluitingscriteria zijn vastgesteld die niet gelden voor de polikliniek. Patiënten met acute verwijzingen, bijvoorbeeld ten gevolge van een ernstig knietrauma, werden niet uitgenodigd voor het gezamenlijk consult. Bovendien konden verschillen optreden, doordat vanwege specifieke consultatiedoelen (nascholing, 'second opinion') patiënten aan het gezamenlijk consult deelnamen die in de gebruikelijke zorg wellicht niet of in een later stadium zouden worden verwezen.

De patiënten van de peilingsgroep scoorden uitsluitend hoger op het gebied van de door huisartsen gepercipieerde mate van hinder. De huisartsen lijken het gezamenlijk consult dus te hebben gebruikt voor klachten die zij mogelijk wat minder hinderlijk inschatten dan wanneer zij verwezen. De uitsluitingscriteria van het onderzoeksproject kunnen dit verschil voor een deel verklaren. Motieven voor het gezamenlijk consult zoals 'ik wilde zelf een second opinion' of 'ik wilde vaardigheden ontwikkelen bij dit type probleem' bij minder hinderlijke klachten kunnen hieraan mede ten grondslag liggen.

$\mathrm{Bij}$ verdere analyse van de gegevens van de peilingsgroep blijkt allereerst, dat de huisartsen bij een opmerkelijk hoog aantal (52\%) van de verwezen patiënten van mening waren dat een gezamenlijk consult gewenst zou zijn geweest. Het hoge aantal wensen voor een gezamenlijk consult komt wellicht overeen met het idee dat het merendeel van de klachten van het bewegingsapparaat door huisartsen te behandelen is en met de wens van de huisartsen te komen tot een betere communicatie met en ondersteuning van de tweede lijn. (5,6,10-13)

Het volgens de huisartsen al dan niet wenselijk zijn van een gezamenlijk consult bij reeds verwezen patiënten hangt wat betreft een aantal klachtkenmerken en belevingen niet samen met de items 'duur', 'hinder', 'bezorgdheid' en 'verzoek om verwijzing'. Er kunnen andere inhoudelijke redenen voor een gezamenlijk consult. 
De motieven van de huisartsen bij de verwijzingen kunnen hieromtrent informatie verstrekken. $(13,14)$

Bij patiënten waarvoor de huisartsen een gezamenlijk consult wensten scoorden de motieven: 'geen duidelijke diagnose', 'behoefte aan een second opinion', 'het ontbreken van een therapeutisch plan' en 'geen verbetering na eerdere therapie' hoger dan wanneer de huisartsen geen gezamenlijk consult wensten.

$\mathrm{Bij}$ de groep patiënten, waarbij de huisartsen een gezamenlijk consult wensten, was er tevens een opvallend hoge score voor de motieven 'de orthopaedisch chirurg is de meest adequate behandelaar' en 'het plan is niet uitvoerbaar voor de huisarts'. Wellicht kan dit worden verklaard uit de verwachting van de huisartsen, dat met het gezamenlijk consult toch voldaan wordt aan de behoefte tot overleg, op grond waarvan zij de verdere zorg zelfstandig kunnen uitvoeren.

\section{CONCLUSIES}

Van de naar de polikliniek orthopaedie verwezen patiënten kon volgens de verwijzende huisartsen een groot deel $(>50 \%)$ in aanmerking komen voor een gezamenlijk consult. De patiëntengroep komt ten aanzien van een aantal door de huisartsen gescoorde klachtkenmerken en klachtbelevingen belangrijk overeen met de patiënten die in het onderzoeksproject van het gezamenlijk consult deelnemen. Alleen ten aanzien van 'gepercipieerde hinder' scoorden de pariënten van de peilingsgroep hoger.

Wanneer de huisarts bij de verwijzing naar de polikliniek als motief 'geen duidelijke diagnose', 'second opinion', 'geen therapeutisch plan' en/of 'geen verbetering na eerdere therapie' vermeldde, was de kans groter dat hij een gezamenlijk consult wenste.

\section{Literatuur}

I Fry J, Sandler G. Domiciliary consultations: some facts and questions. Br Med J 1988; 297:337-8.

2 Litclejohns PC. Domiciliary consultations - who benefits? JR Coll Gen Pract 1986; 36:313-5.

3 Mullery GP. Home visiting by consultants. Br Med J 1988;296:515-6.

4 Vierhout WPM, Beusmans GHMI, Verwijnen GM, Ooij A van, Gasselt HRM van, Beek JMH van der. Gezamenlijk Consult huisarts-specialist. MC 1987;4:106-9.

5 Long A, Arkins JB. Communications between General Practitioners and consultants. Br Med J 1974;4:456-9.

6 Have JJIM ten, Buwalder J. Hoe het beter kan tussen huisarts en specialist. MC 1990; 45:86-8.

7 Have JJIM ten, Kolker L. Consultatievormen Huisarts-Specialist. O en O 1989.

8 Norell LJS. Consultant sessions in health centres and group practices. Communiry Health 1975;6:306-10.

9 Pop P. Consultaries $1^{\circ}-2^{\circ}$ lijn. Drie jar Diagnostisch Centrum Maastricht. MC 1982; 37:1019-23. 
10 Felson DT, Nunan RF, Dayne SF, Gertman P. Referral of musculoskeleral disease parients by family en general practitioners. Arthritus-Rheumat 1985;28(10):1 156-62.

11 Marinker M, Wilkin D, Metcalfe DH. Referral to hospital: can we do better? Br Med J 1988;297:461-4.

12 Smit DJ de. Consultatie tussen huisarts en specialist. MC 1987;42:849-52.

13 Wennberg JE, Barnes BA, Zubkoff $M$. Professional uncertainly and the problem of supplier-induced demand. Soc Sci Med 1982;16:811-24.

14 Moore AT, Roland MO, How much variation in referral rates among general practitioners is due to change? Br Med J 1989;298:500-2. 


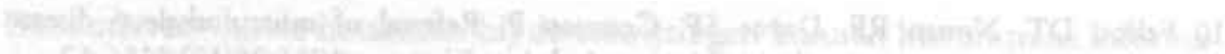

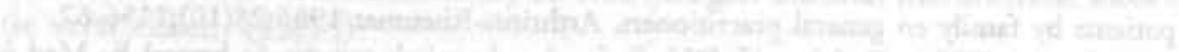

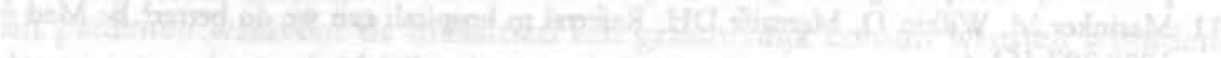

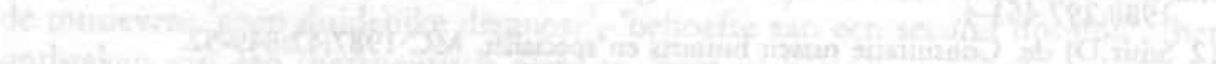

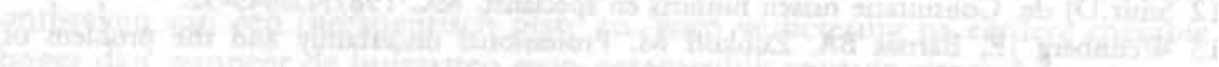

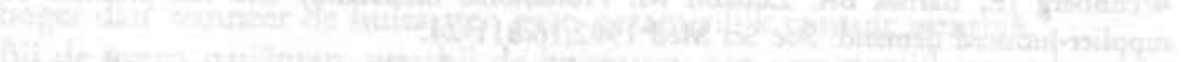

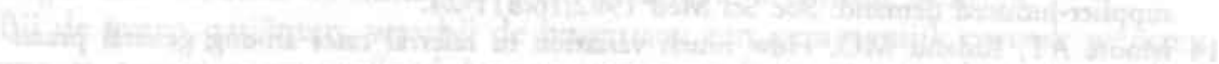

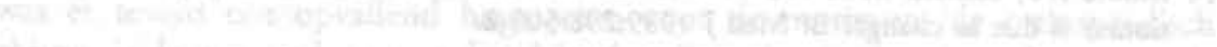

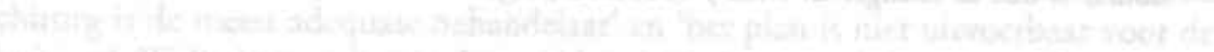

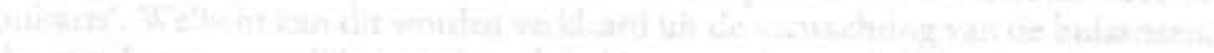

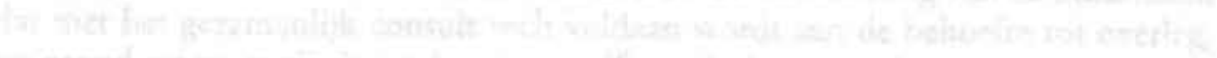

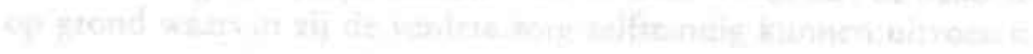

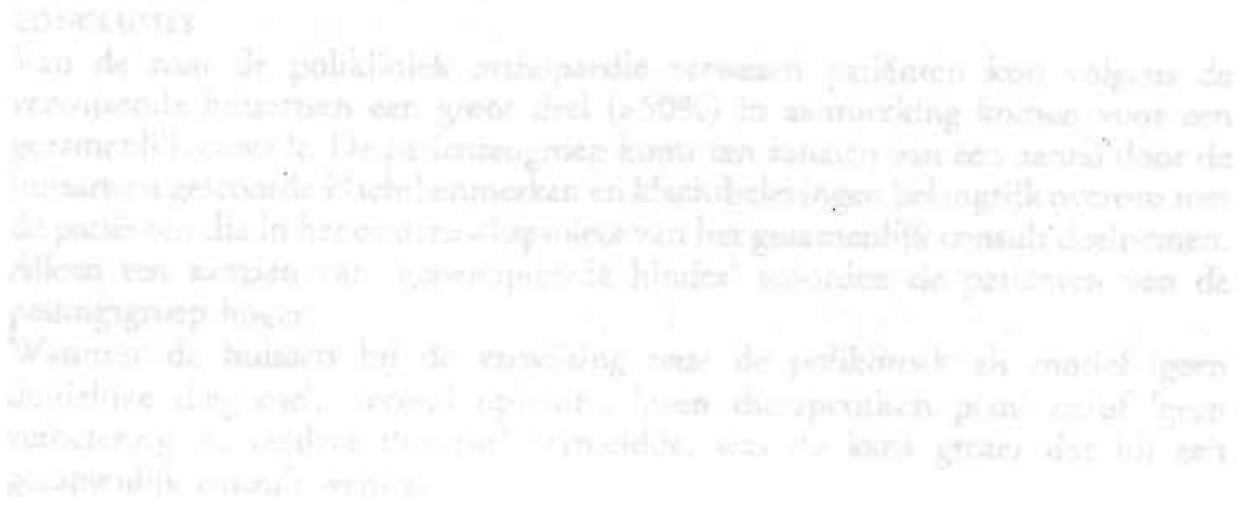




\section{Ervaringen en opinies van huisartsen en orthopaedisch chirurgen omtrent het gezamenlijk consult}

\section{INLEIDING}

Mede vanwege de haalbaarheid was het van belang om door middel van een meer 'bezonken oordeelsmening' inzicht te krijgen in de meningen en ervaringen van deelnemende huisartsen en orthopaedisch chirurgen over het gezamenlijk consult. $\mathrm{Zij}$ zijn daarom na de eindconsulten geënquêteerd. (Zie bijlagen 10 en 11). De opinies hieromtrent van de orthopaedisch chirurgen in Limburg en Oost-Brabant zijn eveneens geïnventariseerd.

De enquêtelijsten bevatten gesloten vragen, een aantal open vragen en een tweetal groepen vragen te beantwoorden door middel van een 5-puntsschaal.

De laatste twee groepen bevatten vragen omtrent de mening met betrekking tot de achteraf gepercipieerde motieven voor het gezamenlijk consult, alsmede over de ervaringen met betrekking tot de taakopvatting en het groepsfunctioneren. Door het geringe aantal geënquêteerden (respectievelijk 11 huisartsen en 4 orthopaedisch chirurgen) geven de resultaten slechts een algemene indruk.

\subsection{Enquête huisartsen}

De enquêteformulieren werden alle volledig ingevuld.

Uit de antwoorden van de 11 huisartsen komt naar voren dat zij de gezamenlijke consultspreekuren geen zware belasting vonden. Tien van hen wilden eventueel doorgaan met andere specialismen.

Bij iedere patiënt werden door de huisartsen de motieven gescoord (zie paragraaf 4.1.).

In de enquête konden de huisartsen dezelfde motieven, maar dan meer in het algemeen geldend voor gezamenlijke consulten, scoren door middel van een 5-puntsschaal.

Wat betreft de gepercipieerde motieven scoorden 'verbetering van onderzoeks-' en 'therapeutische vaardigheden' het hoogst (gemiddeld 4,7 en 4,5), gevolgd door 'kennisvermeerdering' (gemiddeld 4,4). Daarna volgden 'voorkomen van onnodige verwijzingen' $(4,0)$, 'second opinion' $(4,0)$ en 'geruststelling' $(3,9)$. 
Bij de ervaringen vermeldden de huisartsen dat zij het gezamenlijk consult als een prettige taak hadden ervaren en als een uitstekende wijze van deskundigheidsbevordering waardeerden.

Het functioneren in de groep leverde geen moeilijkheden op.

De aandachtspunten 'minder defensief handelen' en 'meer inzicht krijgen in orthopaedie' scoorden het laagst.

\subsection{Enquête en ervaringen van orthopaedisch chirurgen}

De enquêtes van de orthopaedisch chirurgen waren op dezelfde wijze ingedeeld als die van de huisartsen, hoewel sommige specifieke vragen verschilden.

De resultaten waren als volgt:

De planning leverde de orthopaedisch chirurgen geen moeilijkheden op. De belasting werd niet als zwaar ervaren.

$\mathrm{Zij}$ waren van mening dat per gezamenlijk consult 3 tot 6 patiënten konden worden gezien.

Zij waren allen bereid in de toekomst deze werkzaamheden te blijven verrichten. Drie orthopaeden beoordeelden de klachten als sterk gelijkend op die welke normaliter op de polikliniek worden aangeboden. Eén van de orthopaedisch chirurgen was het daarmee 'eens noch oneens'.

Bij het onderwerp 'motieven voor de gezamenlijke consulten' scoorden ook hier 'verbetering van onderzoeks- en therapeutische vaardigheden' het hoogst.

Daarna volgden 'second opinion', 'geruststelling' en 'kennistoename van de huisartsen'.

De orthopaedisch chirurgen merkten nog op dat door het gezamenlijk consult een betere relatie met de huisartsen kon ontstaan, zij een betere 'kijk' kregen op huisartsgeneeskunde, de huisartsen met meer zekerheid hun werkzaamheden konden verrichten, zij meer interesse ontwikkelden op her gebied van orthopaedie, en zij zelf minder vervolgbehandelingen op de polikliniek nodig achtten.

De orthopaeden beoordeelden door middel van een 5-puntsschaal als voordeel voor zichzelf: 'belangrijke voorkennis' (gemiddeld 4,5) en 'belangrijke informatie bij verwijzing' (gemiddeld 4,0) als hoogst scorend.

De items 'patiënt gedraagt zich opener', 'behandeling minder defensief en 'ander zicht op huisartstaak' (allen 3,5) scoorden hierbij lager.

Uit de score ten aanzien van de ervaringen bleken de orthopaedisch chirurgen de gezamenlijke consulten als een prettige taak te ervaren.

Twee van de aan het onderzoek deelnemende orthopaedisch chirurgen hadden tijdens pilotonderzoeken in gezondheidscentra ervaringen opgedaan met de werkwijze van het gezamenlijk consult en hun collegae hiervoor enthousiast gemaakt. (1)

Aan het eind van de onderzoeksperiode bleek door contacten met orthopaedisch chirurgen in de regio's Limburg en Oost-Brabant, dat het merendeel van de in deze regio werkzame orthopaeden positief staat tegenover deelname aan gezamenlijke consultspreekuren in de huisartspraktijk. 
De huisartsen ervoeren het gezamenlijk consult blijkens de enquête als een prettige, zinvolle, haalbare en vooral deskundigheidsbevorderende werkwijze.

Opvallend is dat de scores voor 'de verbetering van de vaardigheden' en 'toename van kennis' hoger zijn dan die van 'verwijzingen voorkomen'.

Waarschijnlijk ervoeren de huisartsen bij deze globale beoordelingswijze, het directe doel in hun werkzaamheden (het zo goed mogelijk zelfstandig uitvoeren van de directe medisch-technische patiëntenbehandeling), als het meest van belang. De meer defensieve motieven scoorden hier lager, hoewel bij de directe patiëntcontacten het aantal defensieve motieven ongeveer gelijk was aan de som van de diagnostische en therapeutische motieven (zie ook paragraaf 4.1.). (2-4) Ook de orthopaedisch chirurgen waardeerden het gezamenlijk consult positief en achtten het goed haalbaar.

Het gezamenlijk consult scoorde bij de orthopaeden vooral positief, omdat zij meenden zowel kwalitatief als communicatief en onderwijskundig zinvol werk te verrichten in een vertrouwde omgeving en sfeer, hetgeen overeenkomt met de resultaten van eerder onderzoek. (5-11)

Zij leken eveneens verbetering van het directe 'handwerk' van de huisartsen (vaardigheden) te herkennen en als een belangrijk motief te waarderen.

Daarnaast ervoeren zij duidelijk voordelen voor hun dagelijks werk.

\section{CONCLUSIES}

De motieven van huisartsen en orthopaedisch chirurgen voor het gezamenlijk consult waren primair gericht op verbeteren van vaardigheden.

Voorts waardeerden de huisartsen vooral de ervaren kennisvermeerdering, terwijl de orthopaedisch chirurgen 'geruststellen' en 'second opinion' meer relevant achtten.

De huisartsen beoordeelden her gezamenlijk consult als een belangrijke methode voor deskundigheidsbevordering, terwijl de orthopaeden vooral de toename van voorkennis en informatie bij eventuele verwijzingen op prijs stelden.

\section{Literatuur}

1 Vierhour WPM, Beusmans GHMI, Verwijnen GM, Ooij A van, Gasselt HRM van, Beek JMH van der. Gezamenlijk Consult huisarts-specialist. MC 1987;4:106-9.

2 Beukema-Siebenga $H$. Ontevredenheid over het patiënt contact. Huisarts Wet 1991; 34(4):166-8.

3 Lamberts H, Janssens PMH. Defensief handelen door huisartsen. Ned Tijdschr Geneeskd 1984;128(13):598-602.

4 Armstrong D, Try J, Armstrong P. Doctor's perceptions of pressure from patients for referral. Br Med J 1991;302:1186-8.

5 Krol LJ. De consument als leidend voorwerp. Proefschrift Universiteit van Amsterdam 1985.

6 Fry J, Sandler G. Domiciliary consultations: some facrs and questions. Br Med J 1988; 297:337-8. 
7 Smit DJ de. Consultatie huisarts-specialist. MC 1987;27:849-52.

8 Smit DJ de. Consultatiebijeenkomst voor huisartsen en specialisten: projekt samenwerking $1^{\circ}-2^{\circ}$ lijn. Amsterdam VU Ziekenhuis, projekt samenwerking $1^{\circ}-2^{\circ}$ lijn 1989.

9 Long A, Atkins JB. Communications between General Practitioners and consultants. Br Med J 1974;4:456-9.

10 Hall EV van, Gill K, Trimbos JB. Gynaecologische consultaties in de huisartspraktijk. MC 1987;4:105-6.

11 Norell LJS. Consultant sessions in health centres and group practices. Community Health 1975;6:306-10. 


\section{Beschouwingen en aanbevelingen}

\subsection{De opzet en uitvoering van het onderzoek}

Het effectiviteitsonderzoek is conform de opzet verlopen, terwijl de uitval beperkt is gebleven. De randomisatiemethode en -procedure lijkt, blijkens de instroomgegevens van beide groepen, goed te hebben voldaan. Als nadeel van de randomisatiemethode binnen de de huisartspraktijk, werd verondersteld, dat door deelname aan het onderzoek toename van kennis en verbetering van vaardigheden van de huisartsen zou ontstaan. Dit zou van invloed zou kunnen zijn op de te leveren zorg, waardoor het 'contrast' tussen interventie- en controlegroep zou afnemen. Ondanks deze veronderstelling konden tussen interventie- en controlegroep een aantal verschillen worden vastgesteld. Het bij de randomisatie toegepaste 'Zelen-design', hetgeen inhield dat de patiënten uitsluitend informatie ontvingen over de gang van zaken van de groep waarin zij terecht waren gekomen, was ons inziens noodzakelijk en zal er toe hebben bijgedragen dat door patiënten geen (voor het onderzoek verstorende) spontane behoefte is geuit aan het gezamenlijk consult.

Wel wisten de huisartsen na de randomisatieprocedure in welke groep de patiënt terecht kwam. Dit kan eveneens van invloed zijn geweest op het verdere verloop, maar hieraan was niet te ontkomen. De huisartsen dienden immers zelf deel te nemen aan het gezamenlijk consult en/of zorg te dragen voor de verdere behandeling. Gezien echter de vervolgduur van het onderzoek van én jaar en omdat het resultaat van de behandeling geen gevolgen had voor de huisartsen, lijkt het niet waarschijnlijk dat dit een belangrijke invloed heeft gehad op het verloop en de verrichtingen of verwijzingen.

Het zogenaamde 'Hawthorne effect' (=onderzochte personen zijn vaak geneigd als gevolg van onderzoek waarbij zij speciale aandacht krijgen een ander gedrag te gaan vertonen) kan in dit onderzoek ook een rol hebben gespeeld. Zowel de interventie- als de controlegroep kregen door het onderzoek specifieke aandacht (enquêtes, eindconsulten). De instroomgegevens konden er echter niet door worden beïnvloed en omdat het interval tot de eindconsulten één jaar bedroeg, lijkt het niet waarschijnlijk dat de specifieke aandacht welke het onderzoek met zich meebracht, de beantwoording van de vragen bij het eindconsult belangrijk, en voor de twee groepen patiënten verschillend, heeft beïnvloed. Wel is het mogelijk dat de antwoorden op vragen met betrekking tot de belevingen na het gezamenlijk consult er door werden beïnvloed. 
Het toetsingsonderzoek van de aan het onderzoek deelnemende huisartsen en de controlegroep huisartsen werd bemoeilijkt door het beperkte aantal deelnemers, waardoor een uitvoerige statistische analyse niet zinvol was.

Het onderzoek had als doel een globaal inzicht te krijgen in de ontwikkeling van kennis en vaardigheden bij de deelnemende huisartsen.

Ten tijde van de start van het onderzoek kon nog geen gebruik worden gemaakt van een specifiek op huisartsen toegesneden toetsingsmethodiek op het gebied van het bewegingsapparaat. Daarnaast is de startmeting in de controlegroep niet gestandaardiseerd afgenomen, hetgeen gevolgen gehad heeft voor de resultaten van de toets.

Terwijl huisartsen de ervaren deskundigheidsbevordering als wellicht de belangrijkste winst van het gezamenlijk consult ervaren, was dit met het toetsingsonderzoek niet hard te maken.

Het 'peilingsonderzoek' liet een opvallend hoge deelname van de huisartsen uit de regio zien. De administratie van de polikliniek orthopaedie bleek een goede ingang om de doelgroep (de huisartsen van de nieuw verwezen patiënten) te bereiken.

De invulling door huisartsen van een beperkt aantal vragenformulieren in aansluiting aan een recente verwijzing naar de polikliniek orthopaedie tijdens vooraf niet bekend gemaakte peilingsperioden, bleek goed haalbaar.

Om mogelijke seizoensinvloeden en het 'Hawthorne effect' bij de verwijzende huisartsen te beperken, werden de enquêteperioden gelimiteerd en gedurende twee aan de huisartsen onbekende perioden verstuurd.

\subsection{Beschouwing met betrekking tot de bevindingen}

INLEIDING

Doelmatigheid en gebrek aan communicatie zijn veelbesproken onderwerpen in de gezondheidszorg. Het verrichte onderzoek met betrekking tot de haalbaarheid en de effectmeting van het gezamenlijk consult voor klachten van het bewegingsapparaat kan gezien worden als evaluatie van een werkwijze die op dat terrein oplossingen zou kunnen bieden. Bijkomende te verwachten resultaten op het gebied van de samenwerking binnen de eerste lijn en ten aanzien van de algemene communicatie tussen huisarts en specialist maakten geen deel uit van het onderzoek. De bevindingen van het onderzoek worden, gerelateerd aan de vraagstellingen van pagina 4,5 en 6 , toegelicht en beschreven.

\section{a. Ten aanzien van de organisatie}

De haalbaarheid van het effectiviteitsonderzoek bleek goed.

Ook uit het peilingsonderzoek kwam naar voren dat een aanzienlijke patiënteninstroom is te verwachten bij eventuele toepassing op grotere schaal.

$\mathrm{Na}$ anderhalf jaar daalde het patiëntenaanbod conform de verwachtingen opvallend, hetgeen te maken kan hebben met het leereffect onder de deelnemende huisartsen. 


\section{b. Ten aanzien van patiënten en klachten}

Er waren bij de instroom van het effectiviteitsonderzoek tussen de interventie- en controlegroep geen significante verschillen ten aanzien van de patiëntvariabelen. Het bleek dat de huisartsen qua klachten en patiënten een specifieke groep voor het gezamenlijk consult uitnodigden.

De klachten betroffen vooral knie-, schouder-, voet-, elleboog-, rug- en heupklachten en vertoonden op het gebied van een aantal klachtkenmerken en belevingsaspecten een sterke overeenkomst met die van door huisartsen uit de regio naar de polikliniek orthopaedie verwezen patiënten.

De orthopaedisch chirurgen meenden dat de patiënten voor het gezamenlijk consult voor een belangrijk deel overeenkwamen met de patiënten die zij gewoonlijk op de polikliniek zien.

De klachten bestonden doorgaans al lang, kwamen vaak voor en scoorden hoog voor belevingsaspecten zoals ernst, hinder, bezorgdheid en pijn. De patiënten scoorden bij deze variabelen hoger dan de huisartsen en waren na de instroomconsulten vaak ongerust over de klacht. De oorzaak daarvan was hen vaak niet duidelijk. Patiënten met langer bestaande klachten hebben een kleinere kans om klachtenvrij te worden, evenals patiënten met psychosociale klachten.

Vaak (ongeveer $60 \%$ ) brachten de huisartsen de klachten in verband met pathologische bevindingen. Vóór het instroommoment waren in verband met de klachten al vaak onderzoeks- en behandelingsverrichtingen uitgevoerd.

Bij $20-25 \%$ van de patiënten was er sprake van co-morbiditeit, psychosociale problemen en/of life-events, en ongeveer $50 \%$ wenste een verwijzing.

Voor ongeveer $15 \%$ van de gezamenlijk consultpatiënten is volgens de orthopaedische chirurgen na één jaar verdere specialistische behandeling nog op zijn plaats.

Veranderingen, vastgesteld na de onderzoeksperiode van één jaar waarin interventie- en controlegroep niet relevant van elkaar verschilden, betroffen de afname van gepercipieerde ernst en hinder ten aanzien van de klachten, de verbetering van de objectieve gezondheidstoestand, de verbetering van de ervaren gezondheidstoestand en het ervaren functioneren.

Effecten gemeten tijdens het effectiviteitsonderzoek, die ten opzichte van de gebruikelijke zorg relevante verschillen ten gunste van het gezamenlijk consult laten zien, zijn de afname van de ongerustheid omtrent de klacht bij de patiënten, de toename van het aantal klachtenvrije patiënten en de daling van het aantal verwijzingen en diagnostische verrichtingen. Dit betekent dat een aantal patiënten voordelen ondervond van het gezamenlijk consult, terwijl de zorg doelmatiger was.

Bij patiënten met schouder-, elleboog-, hand- of voetklachten was de afname van het aantal verwijzingen in de interventiegroep meer dan gemiddeld.

Ook 'ongeruste' patiënten, patiënten met 'co-morbiditeit' en patiënten met 'pathologie gerelateerd aan de klacht' werden na her gezamenlijk consult minder vaak verwezen. Verondersteld kan worden dat de huisarts hierbij in staat wordt gesteld om patiënten behorend tot zijn eigenlijke 'work-load' beter te behandelen, waarbij tevens een aantal 'riskant te achten' verwijzingen worden voorkomen. 
Als patiënten werden verwezen, gebeurde dat in beide groepen overwegend binnen drie maanden na de instroom. Van een uitsteleffect (kans op te late verwijzing) door het gezamenlijk consult blijkt wat betreft verwijzen geen sprake te zijn.

Patiënten in aanmerking komend voor het gezamenlijk consult wilden, zoals eerder werd beschreven, vaak worden verwezen. Deze wens werd echter in beide groepen niet gevolgd door een voor de betreffende groep meer dan gemiddeld aantal verwijzingen naar specialisten.

Het aantal bezoeken aan de huisarts is in beide groepen vrijwel gelijk.

Het aantal bezoeken aan de orthopaedisch chirurg bedraagt in de controlegroep gemiddeld bijna het dubbele van dat van de interventiegroep. Dit laatste gold ook voor het laboratoriumonderzoek.

De huisartsen en orthopaedisch chirurgen tezamen vroegen vaker röntgenonderzoek aan bij patiënten van de controlegroep en bij langdurige en recidiverende klachten. In de interventiegroep werd door huisartsen en orthopaedisch chirurgen vaker röntgenonderzoek aangevraagd bij het motief 'somatische fixatie voorkomen', in de controlegroep vooral bij langdurige en recidiverende klachten.

Medicatie werd bij gebruikelijke zorg vooral voorgeschreven bij patiënten met ernstige klachten en psychosociale problemen, na het gezamenlijk consult vooral bij ernstige klachten.

Injecties, in de gebruikelijke zorg vooral toegepast door de orthopaedisch chirurgen, werden na de gezamenlijke consulten vooral door de huisartsen gegeven.

De verwijzingen voor fysiorherapie op advies van huisarts en orthopaedisch chirurg tezamen, werden vaker gezien bij aanwezigheid van psychosociale factoren en bij het motief 'patiënt ongerust'.

Operatieve behandelingen werden in beide groepen in vrijwel dezelfde aantallen uitgevoerd.

$\mathrm{Na}$ het gezamenlijk consult werd als gevolg van het geringer aantal verwijzingen en verrichtingen, vergeleken met de gebruikelijke zorg, een kostendaling vastgesteld. De gemiddelde kostendaling per patiënt kan voor dekking van de personele kosten van het gezamenlijk consult zorgen.

\section{c. Ten aanzien van huisartsen en orthopaedisch chirurgen}

Als motieven voor de gezamenlijke consulten scoorden 'kennisvermeerdering', 'overbodige verwijzing voorkomen' en 'second opinion' bij huisartsen het hoogst. Bij patiënten waarbij de huisartsen voorafgaand aan het gezamenlijk consult als motief 'onzekere diagnose' en 'vaardigheden ontwikkelen' aankruisten, is de vermindering van het aantal verwijzingen na én jaar het grootst.

Bij patiënten van de interventiegroep met het motief 'vaardigheden ontwikkelen' is door de huisartsen vaak injectietherapie toegepast, terwijl in de controlegroep de orthopaedisch chirurg deze behandeling vaak uitvoerde. Dit motief werd bovendien vaak gescoord bij 'schouderklachten' en bij 'tendinitiden'. Het blijkt dat huisartsen zich bekwaamden in het geven van injecties als behandelingswijze bij schouderklachten en tendinitiden. 
Hoewel door middel van het toetsingsonderzoek na de gezamenlijke consulten een lichte verbetering van de vaardigheden van de huisartsen op het gebied van orthopaedie lijkt te zijn, was dit voor kennisvermeerdering niet het geval. (De niet gestandaardiseerde startmeting zal hierop invloed hebben gehad).

Klachten gezien binnen één jaar, identiek aan die welke door de huisartsen aangeboden zijn voor gezamenlijke consulten ( $60 \%$ van de aangeboden klachten), werden naar de mening van de huisartsen sindsdien bij $80 \%$ zonder verwijzing behandeld. Volgens de huisartsen zou dit vooral het gevolg zijn van 'toename van kennis' en 'verbetering van de vaardigheden'. De huisartsen ervoeren gezamenlijke consulten vooral als een belangrijke deskundigheidsbevorderende werkwijze.

De orthopaedisch chirurgen meenden dat $2 / 3$ deel van de voor het gezamenlijk consult aangeboden patiëntenpopulatie zelfstandig door de huisarts kan worden behandeld. De door hun te bieden hulp bij de kennisvermeerdering van de huisartsen zagen zij als belangrijkste doel, terwijl zij voor zichzelf de toename van voorkennis en informatie bij eventuele verwijzingen waardeerden.

Twee van de aan het onderzoek deelnemende orthopaedisch chirurgen hadden tijdens pilot-onderzoeken in gezondheidscentra ervaring opgedaan met de werkwijze van het gezamenlijk consult en zij hadden hun collegae hiervoor enthousiast gemaakt. Aan het eind van de onderzoeksperiode bleek door contacten met orthopaedisch chirurgen in de regio's Limburg en Oost-Brabant, dat het merendeel van de in deze regio werkzame orthopaeden positief staat tegenover deelname aan gezamenlijke consultspreekuren in de huisartspraktijk.

In schema 8.2.I staat een aantal van bovenstaande conclusies gerubriceerd weergegeven. Hierin zijn in de le kolom de variabelen beschreven. In de $2 e$ kolom zijn de verbanden te zien tussen de variabelen en de kans op een relatief groter aantal verwijzingen of verrichtingen in het onderzoeksjaar. Als voorbeeld kan dienen dat de variabele 'duur' (duur van de klacht (kort of lang) voorafgaand aan het instroommoment) bij de gebruikelijke zorg een grotere kans $(+)$ geeft op in dit geval toename van het aantal verrichtingen (röntgenfoto's).

In de $3 \mathrm{e}$ kolom is te zien welke verandering in het onderzoeksjaar als gevolg van het gezamenlijk consult is vastgesteld. Bijvoorbeeld: de variabele 'duur' was hierbij neutraal $(O)$ omdat de aan het instroommoment voorafgaande duur van de klacht niet kan worden beïnvloed door de behandeling tijdens het onderzoek. De variabele 'type klacht' scoorde positief $(\uparrow)$ omdat bij specifieke klachten (bijvoorbeeld schouderklachten) in de interventiegroep minder vaak verwijzingen werden gezien. 


\begin{tabular}{ccc}
\hline & Voorspeller & Verandering \\
effect ten aanzien van een & vastgesteld tijdens het \\
grotere kans op venwijzing & jaar van onderzoek als \\
entof verrichtingen bij & gevolg van het gezamen- \\
gebruikelijke zorg & lijk consult in vergelijking \\
& & tot gebruikelijke zorg. \\
\hline
\end{tabular}

Patient- en klachtvariabelen bij instroom: Wlachtkenmerk:

$$
\begin{aligned}
& \text {-duur } \\
& \text {-type klacht }
\end{aligned}
$$

$+$

$+$

$+$

$+$

$+$

0

$+$

O

0

0

o

n.v.t.

n.v.t.

n.v.t.

$+$

n.v.t.

n.v.t.

n.v.t. $\uparrow$

n.v.t.

o $\stackrel{0}{\uparrow}$

O

n.v.t.

O

n.v.t.

0

O

n.v.t.

n.v.t. $\uparrow$ $\uparrow$

$\uparrow$

n.v.t.

Orthopaedisch chirurg en gezamenlijk con-

sult:

betere Informatie naar specialist

specialistische behandeling nog geindiceerd

\begin{tabular}{ll}
\hline$=$ & van invloed \\
$O=$ & neutraal (niet van invloed, geen verandering) \\
$T=$ & positief (afname klacht, daling verrichtingen etc.) \\
$\downarrow=$ & negatiol (toename klacht) \\
n.v.t. $=$ & niet van toepassing
\end{tabular}


De behoefte aan overleg tussen huisartsen en specialisten over hun patiënten, blijkt inderdaad voldoende om gezamenlijke consultspreekuren voor klachten van het bewegingsapparaat haalbaar te doen zijn.

De na ongeveer $1 \frac{1}{2}$ jaar optredende daling van het patiëntenaanbod lijkt niet het gevolg te zijn van negatieve motieven zoals 'tijdgebrek' en 'afkeer van het herhalen van onderzoek' maar veeleer van nascholingseffecten, waardoor de huisartsen meenden minder vaak overleg nodig te hebben.

Gezamenlijke consulten bleken al eerder voor verschillende vakgebieden en met verschillende doelen haalbaar. (1-7)

De doelgroep voor het gezamenlijk consult lijkt voor een deel te bestaan uit patiënten, waarbij op de huisarts veel druk wordt uitgeoefend om te verwijzen (vaak wens verwijzing, lange duur van de klacht, vaak ongerustheid).

Blijkens eerder onderzoek wordt hierbij vaak voor, in medisch-technische zin niet goed verdedigbare 'doe-oplossingen' (diagnostische en therapeutische verrichtingen) en verwijzingen, gekozen. (8-12)

Ook co-morbiditeit, psychosociale aspecten en life-events kunnen vaak een rol spelen bij de beslissing om te verwijzen. Juist bij patiënten waarbij deze aspecten een rol spelen, zou blijkens eerder onderzoek, de poortwachtersfunktie van de huisarts vaak als bescherming tegen overbehandeling moeten dienen. (13-23)

Gezien de aangeboden klachren lijkt verwijzing hierbij vaak niet noodzakelijk. Dit is conform de mening van de aan het onderzoek deelnemende orthopaedisch chirurgen. Het komt bovendien overeen met de bevindingen uit eerder onderzoek, waarbij bleek dat de aangeboden klachten bij het gezamenlijk consult met betrekking tot een aantal kenmerken, belangrijke overeenkomsten vertoonden met die van patiënten, welke normaliter naar de polikliniek orthopaedie worden verwezen. (24)

De meer dan gemiddelde daling van het aantal verwijzingen bij bepaalde klachren en bij 'ongeruste' patiënten, bij 'co-morbiditeit' en bij 'pathologie gerelateerd aan de klacht' lijkt overeen te komen met de conclusies uit eerder onderzoek en op verschillende gronden te verklaren.

Bij schouderklachten is de relatief grotere daling van het aantal verwijzingen waarschijnlijk het gevolg van de ontwikkeling van de vaardigheden van de huisartsen. Bij deze klachten gold blijkens het onderzoek vaker 'vaardigheden ontwikkelen' als motief voor het gezamenlijk consult. Ook bij de behandeling door middel van 'injecties' was dit het geval. Bovendien is bekend dat bij schouderklachten vaak behandelingen door middel van injecties plaatsvinden. (25)

De daling van het aantal verwijzingen bij ongeruste patiënten kan zijn ontstaan doordat het gezamenlijk consult de ongerustheid doet afnemen. Huisartsen voelen zich blijkbaar na het gezamenlijk consult beter in staat om patiënten te behandelen met co-morbiditeit en pathologie gerelateerd aan de klacht. Het gezamenlijk consult zorgt mogelijk bij deze patiënten voor een completer beeld en plan met behulp waarvan de huisarts zich beter geëquipeerd voelt. 
De daling van het aantal verwijzingen voor specifieke klachten en omstandigheden, alsmede de ervaringen met injectietherapie bij schouderklachten komen overeen met eerdere onderzoeksresultaten. (10-12,26-29)

De bevinding dat 'wens verwijzing' niet werd gevolgd door relatief meer verwijzingen is opvallend en niet overeenkomstig eerder onderzoek. $(29,30)$

Dit zou verband kunnen houden met de bevinding dat, hoewel de wens tot verwijzing vaak aanwezig was, deze door de huisartsen veelal aan de verkeerde patiënt werd toebedacht.

Opmerkelijk is dat het aantal consulten bij de huisarts in beide groepen vrijwel hetzelfde was, terwijl, vergeleken met de controlegroep, in de interventiegroep het dubbele aantal patiënten zonder verwijzing werd behandeld. De klachten van het bewegingsapparaat resulteerden na het gezamenlijk consult blijkbaar niet in frequente bezoeken aan de huisarts.

De bezoeken aan de orthopaedisch chirurgen verschilden wel per groep, waarbij de specialistische bezoeken in de controlegroep in aantal bijna het dubbele bedroegen van die in de interventiegroep. Wel bezochten de verwezen patiënten van de interventiegroep de orthopaedisch chirurg gemiddeld vaker dan de patiënten van de controlegroep. Dit kan het gevolg zijn van de samenstelling van de groep verwezen patiënten. De verwezen patiënten van de controlegroep bevatten waarschijnlijk meer patiënten met eenvoudiger ziektebeelden, waarvoor met een kleiner aantal consulten is volstaan.

Diagnostische onderzoeken werden na het gezamenlijk consult opvallend minder vaak verricht, terwijl therapeutische verrichtingen voor een belangrijk deel en in iets mindere mate door de huisartsen werden uitgevoerd. Dit lijkt te kunnen worden verklaard door de bevindingen dat de diagnostische onderzoeken vaker bij 'defensieve motieven' werden verricht, terwijl de therapeutische verrichtingen deels bij specifieke klachten (schouderklachten, tendinitiden) en deels ook bij ontbreken van 'harde medische argumenten' werden uitgevoerd. De therapeutische verrichtingen vonden juist vaker plaats bij 'ongeruste patiënten' en bij 'psychosociale problemen'.

Ook uit eerder onderzoek is bekend dat bij daling van het aantal verwijzingen, het diagnostisch onderzoek door huisartsen kon worden overgenomen, evenals een aantal therapeutische verrichtingen. $(31,32)$

Het overeenkomstige aantal operatieve behandelingen in beide groepen is opmerkelijk, waar in eerder onderzoek steeds werd vastgesteld dat het aantal opnamen en operaties sterk gerelateerd is aan het aantal verwijzingen. (33-35)

Waarschijnlijk is in het onderzoek de indicatiestelling scherp en consistent geweest.

De vastgestelde kostendaling maakt het mogelijk om gezamenlijke consulten zonder verdere kostenstijging in de gezondheidszorg in te voeren.

De kostendaling komt overeen met de bevinding dat studies met kwaliteitsbevordering en kostenverlaging als uitgangspunt, vaak én betere kwaliteit én lagere kosten als resultaat hebben. $(36,37)$

Geconcludeerd kan worden dat het gezamenlijk consult door een doelmatiger wijze van werken leidt tot een daling van het aantal verwijzingen en verrichtin- 
gen, terwijl de gezondheidsuitkomsten er niet minder om zijn. Het draagt bij tot een verbetering in de communicatie tussen huisarts en specialist en levert een bijdrage aan een kostenbesparing in de gezondheidszorg.

\subsection{Aanbevelingen}

- Gezien de resultaten van het uitgevoerde onderzoek en de eerdere onderzoeken op dit gebied, achten wij het van belang de zorgverzekeraars te adviseren in diverse regio's (bij voorkeur in regio's met polikliniekwachtlijsten en/of hoge verwijscijfers orthopaedie) daartoe gemotiveerde huisartsen en orthopaedisch chirurgen de mogelijkheid te bieden om regelmatig gezamenlijke consultspreekuren te houden.

- Een gestructureerde begeleiding moet hierbij worden gewaarborgd. De honorerings- en organisatiestructuur zou conform die van de momenteel reeds functionerende F.T.O.(Farmaco Therapie Overleg)-groepen kunnen geschieden.

- Daarnaast verdient het aanbeveling een onderzoek uit te voeren naar de effecten van het gezamenlijk consult verricht door huisartsen samen met andere specialismen. De specialismen die hiervoor in aanmerking komen, zijn die, waarbij patiënten waarvoor het gezamenlijk consult wenselijk wordt geacht, in de huisartspraktijk met een redelijke frequentie (minimaal 1-2x per maand) worden gezien en waarvoor een uitvoerige medisch-technische outillage niet noodzakelijk is.

Gedacht kan worden aan de specialismen cardiologie, KNO, dermatologie en interne geneeskunde.

- Bij de keuze van onderwerpen voor scholing (huisartsopleiding) en deskundigheidsbevordering van huisartsen, lijkt het zinvol gebruik te maken van klachten en problemen die regelmatig tijdens gezamenlijke consulten aan de orde worden gesteld.

- Huisartsen doen er goed aan regelmatig bij hun patiënten na te gaan in hoeverre er een wens tot verwijzing bestaat en in hoeverre er inzicht in de klacht is, omdat blijkens ons onderzoek de wensen en meningen van de patiënten vaak afwijken van de percepties hieromtrent bij de huisartsen, terwijl zij een belangrijke rol spelen in het verwijzingsproces. Door deze verschillen te signaleren worden zij bespreekbaar en te beïnvloeden.

- Het verdient aanbeveling bij klachten van het bewegingsapparaat nader onderzoek te verrichten naar het verband tussen de aanwezigheid van psychosociale problemen, het recidiveren van de klachten en het verloop.

Dit omdat in het onderzoek bij psychosociale problemen de kans om klachtenvrij te worden significant kleiner was en omdat ook verrichtingen op opvallende wijze gerelateerd bleken aan psychosociale problemen en recidiefklachten. De kans op succes bij behandeling lijkt hierbij gering, terwijl opvallend veel verrichtingen worden uitgevoerd. 


\section{Literatuur}

1 Long A, Arkins JB. Communications between General Practitioners and consultants. Br Med J 1974;4:456-9.

2 Wersch-Spek MCM van de. De verpleeghuisarts als medisch consulent in de eerstelijnsgezondheidszorg. MC 1987;39:1243-4.

3 Wouden JC van der, Dokter HJ. Samenwerking tussen huisarts en specialist bij patiënten met kanker. Huisarts Wet 1989;32(2):51-5.

4 Fry J, Sandler G. Domiciliary consultations: some facts and questions. Br Med J 1988; 297:337-8.

5 Litrlejohns PC. Domiciliary consultations - who benefits? JR Coll Gen Pract 1986; 36:313-5.

6 Coupland AI, Todd GB. Pattern of domiciliary consultations in the Trent region. $\mathrm{Br}$ Med J 1985;290:1399-1402.

7 Mullery GP. Home visiting by consultants. Br Med J 1988;296:515-6.

8 Armstrong D, Try J, Armstrong P. Doctor's perception of pressure from patients for referral. Br Med J 1991;302:1186-8.

9 Krol L. De consument als leidend voorwerp in de gezondheidszorg: onderzoek naar achtergronden en verwijzingen naar de kinderarts. Proefschrift Universiteit van Amsterdam 1985.

10 Jongh TOH de. Ongerustheid, een eerstelijnsziekte. MC 1987;26:828-30.

11 Jongh TOH de. Verwijzingen, verwachtingen en effecten. MC 1986;16:511-5.

12 Kuyvenhoven MM, Spreeuwenberg C. Huisarts en diagnostisch proces. Metamedia 1984;63:18-32.

13 Lamberts $\mathrm{H}$, Janssens PMH. Defensief handelen door huisartsen. Ned Tijdschr Geneeskd 1984;128(13):598-602.

14 Franks P, Clancy CM, Nutring PA. Gatekeeping revisited-protecting patients from overtreatment. N Engl J Med 1992;327(6):424-9.

15 Basis-takenpakket van de huisarts. Utrecht: LHV 1982.

16 Meyboom WA. Schaadt overdaad in de (huisarts)geneeskunde? The Practitioner 1991; 8:568

17 Post D. Iatrogene ziekren: een onderzoek naar oorsprong en omvang. Stafleu weten. uitg. Alphen a.d. Rijn 1984.

18 Knottnerus JA. Medical decision making by general practitioners and specialists. Fam Pract 1991;8(4):305-7.

19 Meer K. van der, Smith RJA. Pariënten met chronisch klaaggedrag in de huisartspraktijk. Huisarts Wet 1991;35(1):13-7.

20 Kuyvenhoven MM, Jacobs HM, Touw-Orten FWMM, Es JC van. Verschillen in hulpverlening bij pariënten met vage klachten. Huisarts Wet 1986;29:65-71.

21 Lamberts N, Probleemgedrag in de eerste lijn. Huisarts Wet 1975;18:492-502.

22 Verhaak PFM. Functionele klachten: de nieuwe kleren van de keizer? Huisarts Wet 1988;31:25-37.

23 Huygen FJA. Preventie van somatische fixarie (1). Geschiedenis van een onderzoeksprojekt. Huisarts Wer 1978;21:363-5.

24 Felson DT, Meenan RF, Dayno SF, Gertman P. Referral of musculoskeletal disease parients by family en general practitioners. Arthritis-Rheum 1985;28(10):1156-62

25 Ellman MD, c.s. Hulp voor de stijve, pijnlijke schouder. Patient Care juni 1986:17-28.

26 Waitzkin H. Doctor-patient communication. Clinical implications of social scientific research. JAMA 1984;252(17):2441-6. 
27 Cassee ETh. Naar de dokter: enkele achtergronden van ziektebeelden en gezondheidszorg. Meppel: Boom 1973.

28 Southgate LJ, Bass MJ. Determinations of worries and expectarions of family practice patients. J Fam Pract 1983;16(2):339-44.

29 Engelsman C, Geertsema A, Haayen-Ruskamp FM. De verandering van de gezondheidstoestand en de ongerustheid van de patiënt na een verwijzing. Huisarts Wet 1993; 36(4):128-33.

$30 \mathrm{Krol} \mathrm{H}$. De patiënt als leidend voorwerp. Dissertatie Universiteit van Amsterdam 1985.

31 Dopheide JP, Zee J van der. Verwijscijfers en diagnostische faciliteiten voor huisartsen. MC 1980;35:897.

32 Groenewegen PP. Verrichtingen in de huisartsprakrijk. MC 1990;19:608-611.

33 Huygen FJA, Melker RA de. Over het verwijzen door de huisarts. MC 1973;28:1299.

34 Flohl R. Massloze Medicin, Springer Verslag Berlin 1979.

35 Mokkink HGA. Ziekenfondscijfers als parameter over het handelen van huisartsen. Proefschrift Nijmegen KUN 1986.

36 Post D. Iatrogene ziekten: een onderzoek van oorsprong en omvang. Stafleu weten. uitg. Alphen a.d. Rijn 1984.

37 Ven WPMM van de, Winkens CGF, Wohrmann LJE. Doelmatigheid in de gezondheidszorg: een miljardenkwestie. Ned Tijdschr Geneeskd 1988;132(35):1623-7. 
Q4.

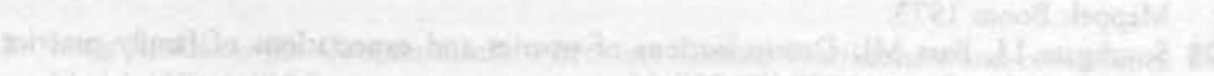

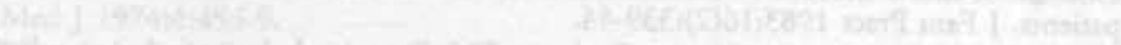

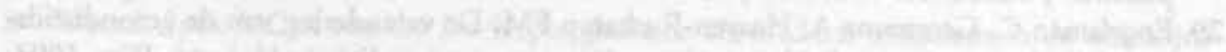

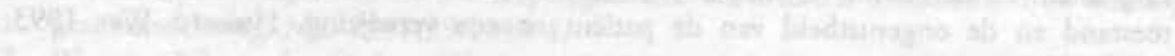
fix

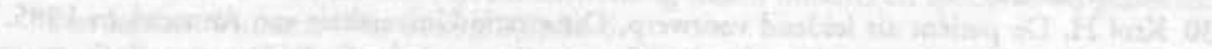

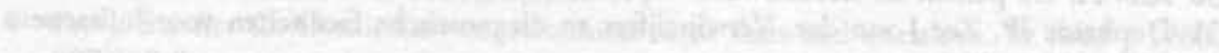

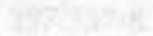

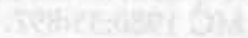

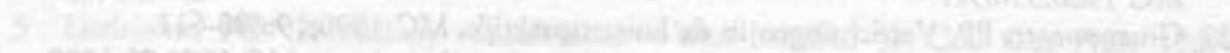

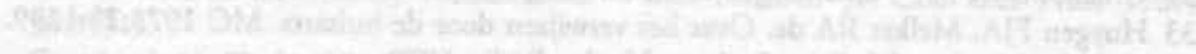

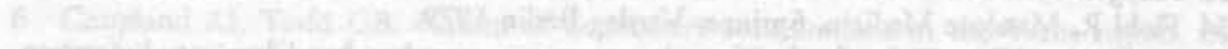

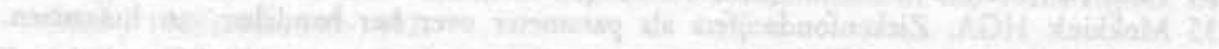

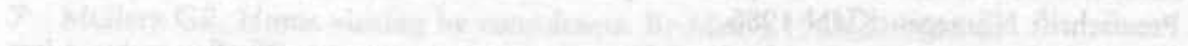

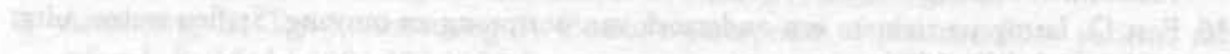

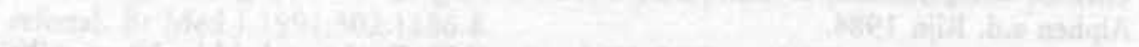

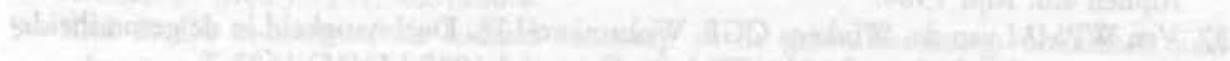

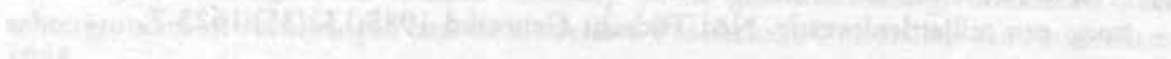

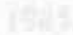

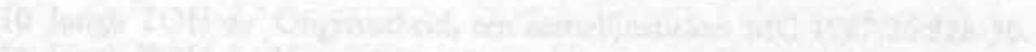

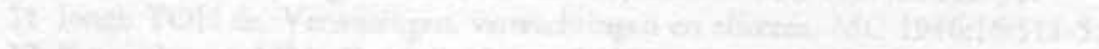

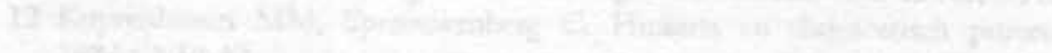

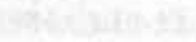

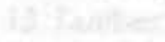

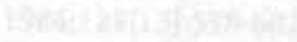

$+$

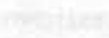

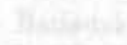

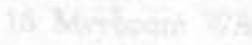

ancis

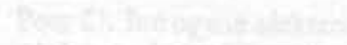

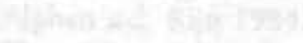

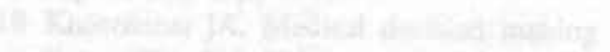

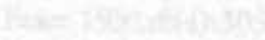

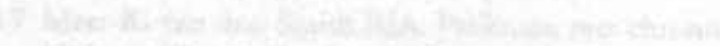

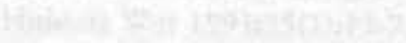

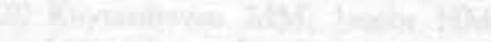

$3+5$
4

The

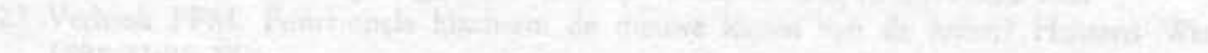

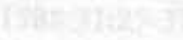

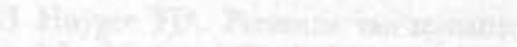

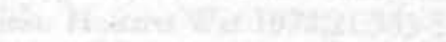

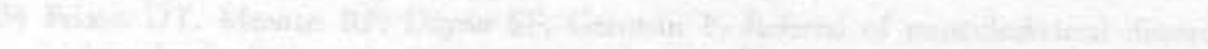

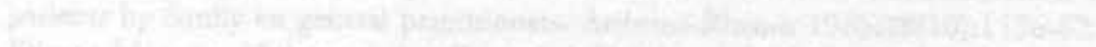

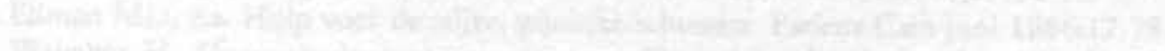

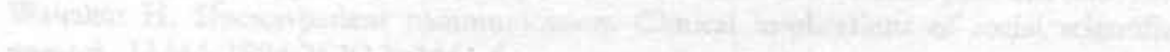

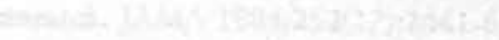




\section{Samenvatting}

Het project 'gezamenlijk consult', gerealiseerd met de steun van het ministerie van WVC, werd uitgevoerd door de vakgroepen Huisartsgeneeskunde en Orthopaedie van de Rijksuniversiteit Limburg en het Diagnostisch Coördinerend Centrum van het AZM te Maastricht.

Het project had als doel na te gaan in hoeverre het gezamenlijk consult gunstige effecten oplevert voor patiënten met klachten van her bewegingsapparaat, en wat betreft kosten en omvang van geleverde zorg. Bij de deelnemende huisartsen werd nagegaan in hoeverre er een gunstige invloed op het gebied van kennis en vaardigheden was waar te nemen.

Het onderzoek waaraan 12 huisartsen uit Maastricht en Meerssen samen met 4 orthopaedisch chirurgen van het Academisch Ziekenhuis Maastricht deelnamen is prospectief gerandomiseerd opgezet en werd uitgevoerd van 1 januari 1989 tot 1 januari 1992.

In hoofdstuk 1 wordt een beschouwing gegeven over het huisartsgeneeskundig handelen bij klachten die door huisartsen als 'moeilijk' worden gekwalificeerd. In verband hiermee worden verwijsgewoonten, kwaliteit en doelmatigheid van zorg, communicatie tussen eerste en tweede lijn, substitutie van zorg en samenwerkingservaringen van huisartsen met specialisten beschreven.

Vervolgens wordt nader ingegaan op de keuze van orthopaedie als specialisme in het onderzoek van het gezamenlijk consult, de doelstelling en de vraagstellingen. Hoofdstuk 2 vervolgt met de beschrijving en motivatie van de onderzoeksopzet. Het gezamenlijk consult van huisarts en orthopaedisch chirurg vond plaats in de huisartspraktijk bij 4 groepen van in totaal 12 huisartsen.

Patiënten, die volgens de huisartsen in aanmerking kwamen voor een gezamenlijk consult, werden door middel van een enveloppe-methode gerandomiseerd in een tweetal groepen.

De patiënten van de ene groep (interventiegroep) namen deel aan her gezamenlijk consult en werden vergeleken met de patiënten van de groep, die niet het gezamenlijk consult kregen, maar op de gewone wijze door de huisarts werden behandeld of verwezen (de controlegroep).

De patiëntencarrières van beide groepen werden gedurende én jaar gevolgd, waarna de patiënten van beide groepen werden onderzocht. Tevens werden gegevens verzameld met betrekking tot het verrichtingen- en verwijzingspatroon.

Van beide groepen patiënten verkregen we na de éénjaarscontroles de resultaten op het gebied van welbevinden, gezondheidstoestand, verrichtingen en verwijzingen. De gezamenlijke praktijkpopulatie van de aan het onderzoek deelnemende huisart- 
sen wordt beschreven, waarbij blijkt dat zij qua leeftijdsverdeling niet belangrijk afwijkt van de regiopopulatie.

Vervolgens wordt de keuze van de deelnemende huisartsen en orthopaedisch chirurgen toegelicht.

$\mathrm{Na}$ beschrijving van de in- en uitsluitingscriteria van het onderzoek wordt ingegaan op de voor het onderzoek berekende noodzakelijke omvang van de onderzoekspopulatie.

De keuze om de randomisatie binnen de huisartspraktijk uit te voeren en de methode van informed consent (Zelen-design) worden toegelicht en gemotiveerd. De opzet van het gezamenlijk consult- en het controlespreekuur wordt beschreven, waarna wordt ingegaan op de toegepaste meetinstrumenten en statistische analyse methoden.

Hoofdstuk 3 beschrijft de resultaten van het effectiviteitsonderzoek. Aan het onderzoek namen 339 patiënten deel, waarbij een uitval van $20 \%$ werd vastgesteld.

De interventie- en controlegroep bevatten na uitval respectievelijk 144 en 128 patiënten. Beide groepen kwamen op het moment van instroom qua achtergrondgegevens, uitval, patiënt- en klachtvariabelen sterk overeen.

Aan het gezamenlijk consult werd vooral deelgenomen door patiënten met vooral knie-, schouder-, voet-, elleboog-, rug- en heupklachten. De klachten waren vaak al langdurig aanwezig.

De patiënten scoorden qua klachtbeleving relatief hoog, terwijl de huisartsen daarmee vergeleken, de klachtbeleving lager inschatten.

Volgens huisartsen was er vaak (60\%) pathologie gerelateerd aan de klacht. Bij overeenkomstige aantallen patiënten werden in beide groepen bij gericht lichamelijk onderzoek afwijkende bevindingen geconstateerd. Bij 1/4 deel van de patiënten werden chronische aandoeningen, psychosociale problemen en life-events vermeld. De algemene lichamelijke toestand van de patiënten was gemiddeld iets slechter dan die van de algemene bevolking. De patiënten waren relatief vaak beperkt op het gebied van 'ervaren functioneren' (werk, activiteiten).

Bovendien wensten de patiënten bij het instroommoment vaak (bijna 50\%) een verwijzing naar de specialist.

Tenslotte was voorafgaand an het instroommoment al vaak diagnostisch onderzoek verricht in verband met de instroomklacht en waren de patiënten al vaak behandeld met fysiotherapie.

Uit de resultaten blijkt dat na de onderzoeksperiode van één jaar in de interventiegroep bijna $1 / 3$ deel van de patiënten werd verwezen. In de controlegroep gebeurde dat bij ongeveer $2 / 3$ deel van de patiënten.

Het welbevinden en de lichamelijke toestand van de patiënten van de interventiegroep verschilden ook na één jaar niet relevant van die van de controlegroep, waarbij in beide groepen een overeenkomstige verbetering was vast te stellen.

Wel waren er na één jaar in de interventiegroep, vergeleken met de controlegroep, meer klachtenvrije patiënten. De kans om klachtenvrij te worden was kleiner bij patiënten met psychosociale problemen.

Bovendien waren de patiënten na het gezamenlijk consult minder ongerust, hadden zij naar hun mening beter inzicht in de oorzaak van de klacht en waren meestal (circa 90\%) tevreden over de behandeling. 
Het aantal bezoeken aan de huisarts was per patiënt in beide groepen vrijwel gelijk, voor de orthopaedisch chirurg was dit in de controlegroep bijna het dubbele van dat van de interventiegroep.

Zoals boven beschreven verschilden de aantallen verwijzingen gedurende het onderzoeksjaar in interventie- en controlegroep, hetzelfde gold voor de verrichtingen. De kans om verwezen te worden was in de controlegroep relatief groter bij patiënten met schouderklachten, chronische aandoeningen en wanneer de huisarts een overleg voorafgaand aan een verwijzing als motief noteerde voor het gezamenlijk consult.

De verwijzingen gebeurden in beide groepen grotendeels binnen een half jaar na instroom.

Diagnostische verrichtingen (laboratorium- en röntgenonderzoek) werden door de specialisten bij patiënten van de interventiegroep, vergeleken met de controlegroep, opvallend minder uitgevoerd.

Een verschuiving (substitutie-effect) was te zien bij de therapeutische verrichtingen (medicatie, injectie en fysiotherapie), al was het verschil in daling van het totale aantal verrichtingen minder groot. Relatief veel verrichtingen werden uitgevoerd bij aanwezigheid van 'defensieve' morieven, psychosociale problemen en bij langdurig bestaande en/of recidiverende klachten.

Het aantal operaties kwam in beide groepen sterk overeen.

$\mathrm{Na}$ het onderzoeksjaar diende volgens de orthopaedisch chirurgen in beide groepen nog circa $15 \%$ van de patiënten specialistische behandeling te krijgen.

De verwijsaantallen van de huisartsen daalden tijdens het onderzoek met bijna $10 \%$, hetgeen een vermindering van verwijzingen van ongeveer 10 patiënten per huisartspraktijk per jaar zou betekenen.

Door de daling van de consulten, verrichtingen en verwijzingen zijn gezamenlijke consulten meer dan kostendekkend.

In hoofdstuk 4 worden voor huisartsen de motieven bij het gezamenlijk consult beschreven, alsmede de ervaren en getoetste deskundigheidsbevordering en de satisfactie.

De motieven 'kennisvermeerdering' en 'overbodige verwijzing voorkomen' kwamen het meest voor als motief voor een gezamenlijk consult.

Relatief minder verwijzingen na het gezamenlijk consult werden gezien bij het motief 'onzeker over diagnose'. Het motief 'overleg voorafgaand aan verwijzing' werd begrijpelijk gevolgd door verhoudingsgewijs meer verwijzingen.

Het motief 'vaardigheden ontwikkelen' kwam zowel vaker voor bij schouderklachten en tendinitiden, als bij injectietherapie en lijkt daardoor een daling van het aantal verwijzingen en verschuiving van het aantal verrichtingen te helpen verklaren.

De deskundigheidsbevordering, die blijkens mededelingen van de aan het onderzoek deelnemende huisartsen en vanuit eerder onderzoek als één van de belangrijkste winstpunten van het gezamenlijk consult moet worden gezien, is nagegaan door te vragen hoe huisartsen na het gezamenlijk consult met identieke problemen omgaan en door middel van een toetsingsonderzoek. 
Het bleek dat huisartsen meenden dat zij binnen één jaar ongeveer $60 \%$ van de klachten opnieuw zagen en dat zij bij deze klachten patiënten vaker dan voorheen zonder verwijzing behandelden.

Dit zou volgens hen vooral het gevolg zijn van kennistoename en verbetering van hun vaardigheden.

Voor het toetsingsonderzoek werden de deelnemende huisartsen samen met een vergelijkbare controlegroep huisartsen bij de start en aan het einde van het onderzoek getoetst wat betreft hun kennis en vaardigheden met betrekking tot het bewegingsapparaat.

$\mathrm{Bij}$ het toetsingsonderzoek leek het erop, dat de huisartsen voornamelijk op het gebied van vaardigheden iets beter scoorden. Huisartsen waren doorgaans tevreden over het gezamenlijk consult. Het niet plaatsvinden van het gezamenlijk consult, hetgeen noodgedwongen het geval was bij de patiënten van de controlegroep, werd achteraf vooral betreurd wanneer patiënten waren verwezen.

Hoofdstuk 5 belicht de informatie-overdracht, de verwijs- en de behandelingsindicaties vanuit het oogpunt van de orthopaedisch chirurgen. De orthopaedisch chirurgen meenden bij $2 / 3$ deel van de patiënten betere informatie te hebben ontvangen. Volgens hen was bij $1 / 3$ deel van de patiënten, die werden aangeboden voor het gezamenlijk consult, een verwijzing op zijn plaats. $\mathrm{Zij}$ meenden dat specialistische behandeling bij $15 \%$ van de patiënten aan het eind van de onderzoeksperiode nog gewenst zou zijn.

Hoofdstuk 6 beschrijft de haalbaarheid van het gezamenlijk consult. Enerzijds is in het kader van het effectiviteitsonderzoek onderzoek verricht naar de daadwerkelijke uitvoering van de gezamenlijk consultspreekuren, geconstateerde uitval en de redenen die daarbij speelden, anderzijds is een peilingsonderzoek uitgevoerd naar de behoefte aan her gezamenlijk consult bij de overige huisartsen van de regio Heuvelland.

Uit de bevindingen van het effectiviteitsonderzoek bleek dat gezamenlijk consultspreekuren gedurende ongeveer $1 \frac{1}{2}$ jaar goed haalbaar zijn. Nadien daalt waarschijnlijk als gevolg van de deskundigheidsbevordering, de behoefte sterk.

Het peilingsonderzoek laat zien dat de huisartsen van de regio Heuvelland bij ongeveer de helft van hun verwijzingen menen dat een gezamenlijk consult gewenst zou zijn. Bovendien lijken de verwezen patiënten met betrekking tot een aantal variabelen sterk overeen te komen met patiënten die werden geselecteerd voor het gezamenlijk consult.

In hoofdstuk 7 worden de ervaringen en opinies over het gezamenlijk consult van de huisartsen en orthopaedisch chirurgen beschreven.

Zowel de huisartsen als de orthopaedisch chirurgen zien als belangrijkste doel het verbeteren van de vaardigheden. De huisartsen vinden de deskundigheidsbevordering voor zichzelf de belangrijkste winst, terwijl de orthopaedisch chirurgen in dit opzicht vooral de betere voorkennis en informatieoverdracht waarderen.

In hoofdstuk 8 wordt de methodologie van het onderzoek kritisch beschouwd en toegelicht. Bovendien worden de belangrijkste bevindingen beschreven en belicht vanuit de literatuur, waarna wordt afgesloten met de aanbevelingen. 


\section{Summary}

The project 'Joint Consultation' sponsored by the Department of Health and Social Security was administered by the General Practice Department and the Orthopaedic Department of the State University of Limburg and the Diagnostic Centre of the AZM in Maastricht.

The aim of the project was to find out to what extent joint consultation is effective for patient with complaints related to the motion system and with regard to costs and care provided.

The study had also to find out to what extent joint consultation is effective in the field of knowledge and competence.

The research project, in which 12 GPs from Maastricht and Meerssen, together with 4 orthopaedic surgeons of the AZM participated, was set up prospectively and at random and was carried out from 1 January 1989 till 1 January 1992. In chapter 1 a survey is given about the GP's medical treatment in cases of complaints classed as 'difficult'. In relation to this it describes reasons for referring patients, quality and efficiency of care, communication between the primary and clinical care, substitution of care and the GP's experiences of cooperation with specialists. Then a closer look is taken at the choice of Orthopaedics as a specialism in the joint consultation project, the aims and problems.

Chapter 2 continues with the description and motivation of the study. The joint consultation of GPs and orthopaedic surgeons took place in the GPs' practices of 12 GPs divided into four groups.

Patients who, according to the GPs were considered suitable for a joint consultation were divided into random groups by means of an envelope method.

The patients of the one group (intervention group) took part in the joint consultation and were compared to the patients of the group who didn't receive the joint consultation, but were either treated by the GP in the conventional way or referred (control group).

The development of the patients in both groups was monitored for a period of one year and after this the patients of both groups were examined.

At the same time information was gathered with regard to the pattern of treatments and referral.

After the one-year check-ups the results were obtained from both groups of patients regarding well-being, state of health, treatments and cases referred. The number of patients of the practices of the participating GPs is described and proves that there is no considerable difference in age structure compared to the 
regional population. Then the choice of the participating GPs and the orthopaedic surgeons is explained. After description of the including and excluding criteria of the research an explanation is given about the extent of the research population.

The choice of working at random within the GPs' practices and the method of informed consent (Zelen-design) are explained and motivated. The idea of the joint consultation and surgeries for check-ups is described and also the measuring instruments applied and statistical analysis methods.

Chapter 3 describes the results of the efficiency study. 339 Patients participated in the research of which $20 \%$ dropped out. After the drop-out the intervention group and the control group contained 144 and 128 patients respectively.

At the moment of intake both groups were very much alike as to back-ground information, drop-out patients and complaints patterns. It was particularly patients which knee, shoulder, foot, elbow, back and hip complaints who took part in the joint consultation. Many of the patients had had the complaints for a long time. The patients considered their complaints to be more serious than did the GPs. According to the GPs pathology was often (60\%) related to the complaint. Different findings were ascertained with similar numbers of patients in both groups in cases of specific physical examination. In the case of $1 / 4$ of the patients chronic complaints, psycho-social problems and life-events were mentioned. The general physical condition of the patients was on average slightly worse compared to that of the general public. The patients were often favily limited with regard to functioning in daily life (work, activities).

Moreover, the patients often wished to be referred to the specialist (nearly $50 \%$ ) at the moment of intake. Finally prior to the moment of intake, diagnostic research had often already been done in relation to the complaint and the patients had often already been treated by a physiotherapist.

It appears from the results that after the one-year period of research nearly $1 / 3$ of the patients in the intervention group was referred; in the control group about $2 / 3$ of the patients was referred.

The well-being and physical condition of the patients in the intervention group didn't differ significantly after one year from those of the control group and a similar improvement could be established in both group. But compared to the control group, there were more patients without complaints in the intervention group after a period of one year. The chance of becoming free of complaints was smaller for patients with psychosocial problems. Moreover, patients were less worried after the joint consultation, they thought they had better insight into the cause of the complaint and most of them $(90 \%)$ were satisfied with the treatment. In both groups the number of visits per patient to the GP was about the same; as for the orthopaedic surgeon the amount in the control group was double that of the intervention group. As previously described, during the year of research, the number of cases referred and the treatments in the intervention group differed from the control group. In the control group the chance of being referred was slightly higher for patients with shoulder complaints, chronic 
complaints and in cases where the GP used a consultation preceding a referral, to bring about a joint consultation. In both groups the referrals usually took place within half a year of the intake. Compared to the control group, diagnostic treatments (laboratory and x-ray examination) were carried out much less by specialists on patients in the intervention group. A shift was noted (substitutioneffect) in the therapeutic treatments (medication, injection, physiotherapy) although the difference in decrease of the total number of treatments was less. Quite a number of treatments were carried out in cases of defensive motives, psychosocial problems and with longstanding and/or recurring complaints. In both groups the number of operations was about the same. According to the orthopaedic surgeons about $15 \%$ of the patients in both groups were due to get specialist treatment after the project year.

The number of cases referred by the GPs decreased by nearly $10 \%$ during the project which would indicate a decrease in referrals of about 10 patients per GP's practice a year. The joint consultations cover their own costs more than adequately.

In chapter 4 the GPs' motives for a joint consultation and the tried and tested know-how and satisfaction are described. The motives 'increased knowledge' and 'prevention of needless referrals' proved to be the main ones for a joint consultation.

In cases of 'uncertain diagnosis' comparatively fewer were referred after a joint consultation. The motive 'consultation prior to referral' was obviously followed by comparatively more referrals. The motive 'developing skills' occurred more often both in cases of shoulder complaints and tendinitis as in cases of injection therapy and therefore it would seem to help to explain a decrease in the number of referrals and a shift in the number of treatments.

It appears that according to the participating GPs and from prior research that the improvement of know-how could be considered one of the most important advantages of joint consultation. Information about this has been obtained by means of a test and by asking GPs after the joint consultation, how they handle identical problems. It appeared that the GPs thought that about $60 \%$ of the complaints returned within one year and patients with similar complaints were more often than previously treated without being referred. According to them, this was due to an increase in know-how and improvement of their skills. The test survey took place at the beginning and end of the study. For this the participating GPs together with a comparable group of GPs (control group) were tested with regard to their knowledge, skills and competence related to the motion system. From the test survey it appeared that the GPs scored slightly better, especially in the field of skills.

Usually the GPs were satisfied with the joint consultation. Not giving a joint consultation, which was inevitable in the case of patients in the control group, was regretted afterwards especially in cases where patients had been referred.

Chapter 5 informs about the reasons for referring and treating from the point of view of the orthopaedic surgeon. With $2 / 3$ of the patients orthopaedic surgeons considered that they had received betrer information. According to them in case 
of $1 / 3$ of the patients who had the chance of a joint consultation, a referral turned out to be justified. They considered that for $15 \%$ of the patients specialist treatment would still be necessary at the end of the research period.

Chapter 6 describes the feasibility of the joint consultation. On the one hand, within the framework of an efficiency survey a study was done as to the actual realisation of the joint consultation surgeries, the registered level of drop-out and the reason for this; on the other hand an opinion poll was carried out as to the need of a joint consultation for the other GPs from the Heuvelland area. It appeared from the results of the efficiency survey that the joint consultation was successful for about $1 \frac{1 / 2}{2}$ years.

Afterwards the need considerably decreased probably due to an increase in knowhow of the GPs. The opinion poll shows that the GPs from the Heuvelland area thought that a joint consultation would be advisable for about half of the cases referred. What's more, in a number of ways the referred patients seem to correspond with the patients selected for the joint consultation.

In chapter 7 the experiences and opinions about the joint consultation of GPs and orthopaedic surgeons are described. Both GPs and orthopaedic surgeons consider improvement of skills to be the main aim. The GPs consider the improvement in know-how to be the main profit for themselves. What the orthopaedic surgeons particularly appreciated in this matter is the fact that they are better informed all round at an early stage.

In chapter 8 the methodology of the study is critically looked at and explained. Moreover, the most important conclusions are described and classified from a literary point of view. Finally recommendations are given. 


\section{Dankwoord}

Het doen van onderzoek en schrijven van een proefschrift deed mij, mede gezien mijn jeugdervaringen, denken aan het bouwen van een schip: je kunt wel iets moois denken te ontwerpen maar de tijd zal leren of aan de verwachtingen kan worden voldaan én het is het een gezamenlijk karwei.

Het werk overziende, bleek het een boeiende, inspirerende, van leuke ontdekkingen voorziene, maar ook flink belastende taak. Eén van de prettige kanten van het werk betrof de ontmoeting van en samenwerking met zo'n groot aantal verschillende mensen.

$\mathrm{Nu}$ alles 'zeewaardig' is gebleken, is het tijd om alle betrokkenen te bedanken. Allereerst mijn dank aan de patiënten die aan het onderzoek deelnamen en naast extra onderzoek de nodige enquêteformulieren tijdig en compleet invulden.

In aansluiting hierop wil ik de huisartsen danken, die op steeds weer enthousiaste wijze aan het effectiviteitsonderzoek deelnamen: E. America, H. Swerts, Th. van Erp en W. Heiligers; A. Vos, K. Verstraete, S. Dijkstra en G. van Pelt; M. Keijsers-Péters, L. Keijsers en R. de Jong; J. Swaans en W. Rizzen, en niet te vergeten hun assistentes, die met plezier de extra taak die het gezamenlijk consult met zich meebracht, vervulden.

Ook de orthopaedisch chirurgen die als consulent optraden: $\mathrm{A}$. van Ooij, $\mathrm{H}$. Arens, R. Geesink, G. Walenkamp vervulden hun taak met veel inzet en enthousiasme. De assistentes van de polikliniek orthopaedie informeerden op accurate wijze over nieuw verwezen patiënten.

Bovendien gaat mijn dank uit naar de huisartsen die deelnamen aan het toetsings- en het peilingsonderzoek, evenals naar de huisartsen P. Castermans, B. Huijnen, Th. Lemmens $t$, P. Stalenhoef, M. Peeters en F. Vissers, die aan het pilot-onderzoek deelnamen.

Vervolgens wil ik graag een aantal betrokkenen met naam en voornaam bedanken voor hun bijdrage.

André Knottnerus, Harry Crebolder en André van Ooij wil ik danken voor de wijze waarop zij het promotorschap inhoud hebben gegeven. André Knottnerus wil ik speciaal bedanken, omdat hij mij op bijzondere wijze tot steun is geweest. Hij heeft mij keer op keer verbaasd doen staan over zijn kennis, zijn onvermoeibare inzet en zijn vermogen essentiële punten snel te herkennen. Ik heb hem leren kennen als een bijzonder integer persoon die als geen ander weet te stimuleren. Harry Crebolder begeleidde op enthousiaste, actieve en opgewekte wijze. André van Ooij is vanaf de 'geboorte' van het gezamenlijk consult door 
zijn lijfelijke deelname als peetvader van het onderzoek te beschouwen. Hij kan bovendien een voorbeeldfunctie vervullen voor de moderne, menselijke, deskundige en relativerende collega-consulent.

Dat het onderzoek voorspoedig verliep, is vooral te danken aan Annemie Wesselingh, die met haar geweldige inzet, zelfstandige opstelling, helder overzicht en loyaliteit steeds alle mogelijke en onmogelijke zaken in het oog hield, soepel liet verlopen en zorgvuldig verwerkte.

George Beusmans steunde met waardevolle adviezen en gedachtenwisselingen vanaf het eerste moment van het gezamenlijk consult.

Op rustige wijze gaf André Ament, als lid van de projectgroep, zinvolle adviezen op het gebied van kosten en baten.

Ton van der Linden, als voorzitter van de beoordelingscommissie, dank ik voor zijn positieve instelling zonder poespas en de ruimte door hem gegeven aan zijn stafleden voor het meewerken aan de gezamenlijke consulten.

Ook Peter Pop waardeer ik in zijn hoedanigheid van lid van de beoordelingscommissie en als coördinator van het Diagnostisch Coördinerend Centrum, voor zijn stimulerende opstelling naar de eerste lijn en zijn nauwkeurige adviezen.

Hans Philipsen, Ferd Sturmans en Theo Voorn, leden van de beoordelingscommissie, dank ik voor hun instemming, persoonlijke en positieve opstelling bij de beoordeling van het proefschrift.

Wim Brouwer en Cees de Geus werkten mee aan de eerste ontwikkelingen en boden ruimte voor de pilotfase van her onderzoek.

Trudie Seegers ben ik uitermate veel dank verschuldigd voor de geweldige en zonnige wijze waarop zij allerhande gegevens in en uit de computer kreeg, en dat zowel in de tijd dat zij in, als 'onder' de vakgroep werkte. Bovendien ben ik haar dankbaar dat zij mij attent maakte op het bestaan van Annemie.

Frits Ruyters startte de registratie bij het begin van het onderzoek en stelde evenals Judith Jansen, herhaaldelijk de p.c. en printer ter beschikking.

Manon van Haaren voerde consciëntieus alle data in.

Bep Köhlen en Tonnie Kleijnen waren steeds bereid hun kennis over te dragen. Voor de ontwikkeling van de vragenlijsten, de ins en outs van VOEG- en SIPlijsten was Frans van der Horst een prettige, immer opgewekte en aanspreekbare steun.

Michiel Cornel hielp incidenteel bij onduidelijke resultaten van de data-analyses. Maarten Verwijnen leverde en becommentarieerde de toetsvragen en zette kanttekeningen bij de resultaten van het toetsingsonderzoek.

Bert Schilte zorgde voor een aantal frisse ideeën bij de start van het onderzoek. Willem Elzinga verdient als student-assistent veel dank voor de vasthoudende wijze waarop hij alle kosten boven water tilde.

Peter Reniers verzorgde op snelle, accurate en onverstoorbare wijze de financiële perikelen van het onderzoek.

De door het Ministerie van WVC voor het onderzoek ingestelde begeleidingscommissie onder voorzitterschap van prof dr. Jan van Es, dank ik voor de positief ervaren begeleiding, de heren Wout Joling en Raymond Knaap voor hun prettige, actieve en medeverantwoordelijk voelende opstelling. 
Ook de assistentes van ons gezondheidscentrum 'de Hofhoek', Maril Coenen en Edith Jongen, verdienen dank voor het gebruik van hun improvisatietalenten wanneer er door de onderzoeksactiviteiten spreekuren moesten worden verschoven.

De Summary was obviously 'the cup of tea' van Ted Pieters, die hiervoor in haar hectische dagen voor Kerstmis nog tijd wist vrij te maken.

Aan het eind van dit dankwoord wil ik mijn moeder bedanken en mijn vader gedenken. Zij legden door hun toewijding de basis voor een tor dusverre gelukkig en evenwichtig bestaan als huisarts, hetgeen nu mede resulteert in dit proefschrift. Pauline bedank ik voor de wijze waarop zij op de voor haar karakteristieke manier ook in deze periode ruimte gaf, rust uitstraalde, steun bood en de sfeer op peil hield, waardoor ons gezamenlijk pad uitstekend begaanbaar bleef.

Hoewel Jeroen en Joost al uit huis waren voordat het meeste werk zich aandiende, zorgden zij vaak voor de broodnodige afleiding en hielpen mij relativeren. Jeroen nam daarbij nog 'geruisloos' een aantal noodzakelijke 'tuintaken' over, waardoor we nu niet in een wildernis wonen.

Joost hielp bij de pogingen in de kostenberekeningen significante verschillen te ontdekken.

Jolanda en Angelique maakten het mogelijk dat Jeroen en Joost minder behoefte hadden aan vaderlijke aandacht.

De vrijwel altijd opgewekte stemming, interesse en enorme energie van Bart hielden mijn humeur op peil en waren een antidotum tegen het verouderen. Mijn dank daarvoor is groot en ik hoop in de toekomst voor hem weer een 'rendabele' vader te zijn. 


\section{Curriculum vitae}

W.P.M. (Nandus) Vierhout werd op 10 mei 1941 te Koudekerke (Zeeland) geboren.

In 1957, na het behalen van het eindexamen HBS-b aan het St. Willibrord College te Goes, begon hij zijn studie Geneeskunde aan de Rijksuniversiteit te Leiden.

Vanaf 1960 tot 1965 was hij tevens werkzaam als student-assistent bij de afdeling Neuro-Anatomie. In 1965 behaalde hij het arts-examen.

$\mathrm{Na}$ werkzaam te zijn geweest in verschillende huisartspraktijken vestigde hij zich medio 1966 in Maastricht.

Eind 1974 associeerde hij zich met G.H.M.I. Beusmans, waarna de gezamenlijke huisartspraktijk vanaf 1977 opging in het gezondheidscentrum 'de Hofhoek' te Maastricht.

Vanaf 1974 is hij part-time verbonden aan de vakgroep Huisartsgeneeskunde van de Rijksuniversiteit Limburg te Maastricht. 


\section{Het gezamenlijk consult van huisarts en specialist in de eerste lijn}

Een nieuwe werkwijze bij klachten van het bewegingsapparaat 


\section{Informatieve brief en vragenlijst voor de patiënt die na de randomisatie deelneemt aan het gezamenlijk consult. (Instroomconsult interventiegroep)}

Geachte Mevrouw/Meneer,

Vandaag kwam $\mathrm{U}$ bij mij in verband met een klacht over het bewegingsapparaat (problemen met spieren, gewrichten of botten). Ik stelde U voor om samen met de orthopaedisch chirurg in de huisartspraktijk uw klacht nog eens te bekijken. Deze werkwijze wil ik graag schriftelijk toelichten.

Het is $U$ natuurlijk bekend dat huisartsen meestal hun patiènten zelf onder behandeling houden, maar ook wel eens verwijzen naar specialisten. De vraag wanneer het beste al of niet verwezen kan worden is daarbij belangrijk.

Om hierbij duidelijkheid te krijgen neem ik deel aan een onderzoek van de Rijksuniversiteit Limburg en het Diagnostisch Centrum te Maastricht. Ik zou het fijn vinden als $U$ hieraan wilt meewerken.

Wat betekent dit voor U?

$\mathrm{U}$ wordt verzocht bijgaande vragenlijst thuis in te vullen en in bijgaande antwoord-enveloppe zo spoedig mogelijk op te sturen.

Over een jaar zal ik $U$ nog een keer vragen dezelfde lijst in te vullen en $U$ wederom uitnodigen voor een gezamenlijk consult. Voor U zijn hier geen kosten aan verbonden.

Alle door $U$ verstrekte gegevens vallen uiteraard onder het Medisch Beroepsgeheim. Uw gegevens zullen dan ook volstrekt vertrouwelijk worden behandeld. Mocht U vragen hebben bij het invullen van de lijst, aarzel dan niet de assistente of mij even om advies te vragen.

Bij voorbaat dank voor Uw medewerking.

Met vriendelijke groeten, 


\section{Aanwijzingon:}

Vult u deze vragenlijst liefst in op de dag dat $\mathrm{u}$ de huisarts bezoekt, maar zeker binnen twee dagen na het zien van de huisarts.

Nadat u de lijst heeft ingevuld kunt u deze in de bijgevoegde antwoord-enveloppe rechtstreeks naar de universiteit opsturen.

De vragenlijst bestaat uit twee delen:

- een eerste deel met een aantal vragen (35);

- een tweede deel met uitspraken over het dagelijkse functioneren.

Alle antwoorden die u geeft worden vertrouwelijk behandeld.

Het invullen van deze lijst neemt ongeveer 30 minuten in beslag.

Bij voorbaat onze hartelijke dank! 
Naam huisarts:

Datum:

Naam:

Voornaam:

Geslacht: Geboortedatum:

Adres:

Woonplaats:

Verzek. ZZL.no.:

E.R. Postcode:

Registratienummer:

1. Met welke klacht bent $\mathrm{u}$ bij de huisarts geweest?

2. Wanneer had U deze klacht voor het eerst?

0 korter dan 1 maand geleden

0 langer dan 1 maand, maar korter dan 6 maanden geleden

0 langer dan 6 maanden, maar korter dan 1 jaar geleden

0 langer dan 1 jaar geleden

3. Wanneer kwam u met deze klacht voor het eerst bij de huisarts?

0 korter dan 1 maand geleden

0 langer dan 1 maand, maar korter dan 6 maanden geleden

0 langer dan 6 maanden, maar korter dan 1 jaar geleden

0 langer dan 1 jaar geleden

4. Bent $\mathrm{u}$ behalve bij de huisarts nog bij andere artsen of therapeuten geweest?

0 nee

0 ja, bij de specialist; $\mathrm{nl}$

0 ja, bij de fysiotherapeut

$0 \mathrm{ja}$, bij een andere therapeut:

0 ja, anders:

Aanwijzing: de vragen 5 tot en met 13 slaan op de situatie vobrdat $u$ bij uw huisarts kwam.

5. Had U last of hinder van de klacht?

0 zeer veel

0 veel

0 matig

0 weinig

0 geen 
6. Veroorzaakte de klacht pijn?
0 zeer veel
0 veel
0 marig
0 weinig
0 geen

7. Hoe ernstig dacht $U$ dat Uw klacht was?

0 heel ernstig

0 ernstig

0 niet zo heel ernstig

0 niet ernstig

0 helemaal niet ernstig

8. Verergert de klacht de laatste tijd?
0 zeer veel
0 veel
0 matig
0 weinig
0 niet

9. Maakte $U$ zich zorgen over deze klacht?
0 zeer veel
0 veel
0 matig
0 weinig
0 geen

10. Heeft u vanwege uw klacht uw aktiviteiten moeten beperken in de afgelopen 12 maanden?
- In uw werk?
0 ja
- In uw vrije tijd?
0 nee
0 ja
0 nee

11. Hoeveel tijd in totaal heeft u vanwege uw klacht uw dagelijkse werkzaamheden niet kunnen doen de afgelopen 12 maanden?
0 dagen
0 1 - 7 dagen
08 - 30 dagen
0 meer dan 30 dagen

12. $\mathrm{Zijn}$ naar uw mening het aantal sociale contacten (ontmoetingen met vrienden, kennissen, familie en buren) afgenomen de afgelopen 12 maanden?

0 ja, ga door met vraag 13

0 nee, ga door met vraag 14 
13. Houdt de afname in sociale contacten verband met uw klacht? $\begin{array}{ll}0 & \text { ja } \\ 0 & \text { nee }\end{array}$

14. Wat had U verwacht dat Uw huisarts zou doen?

(eventueel meerdere hokjes aankruisen)

0 dat hij het zelf zou afhandelen (evt. met röntgen-foto's)

0 dat hij u zou verwijzen naar een specialist

0 dat hij u zou verwijzen naar een therapeut (bv. fysiotherapie, Mensendieck, Cesar)

0 ik heb daar niet over nagedacht

0 weet ik niet

0 anders, $\mathrm{nl}$ :

15. Wat wilde u zelf dat uw huisarts zou doen?

(eventueel meerdere hokjes aankruisen)

0 dat hij het zelf zou afhandelen (evt. met röntgen-foto's)

0 dat hij u zou verwijzen naar een specialist

0 dat hij u zou verwijzen naar een therapeur (bv. fysiotherapie, Mensendieck, Cesar)

0 ik heb daar niet over nagedacht

0 weet ik niet

0 anders, $\mathrm{nl}$.

Aanwijzing: vraag 16 tot en met 22 slaan op de situatie $n u, n a$ uw bezoek aan de huisarts.

16. Bent u i.v.m. uw klacht gerustgesteld?

0 volledig

0 voldoende

0 matig

0 weinig

0 niet

17. Heeft u voldoende aandacht gekregen?

0 ruim voldoende

0 voldoende

0 matig

0 weinig

0 geen 
18. Is het voor u duidelijk waardoor de klachten veroorzaakt worden?
0 volledig
0 voldoende
0 matig
0 weinig
0 niet

19. Hoe beoordeelt u uw eigen gezondheid als geheel?
0 zeer goed
0 goed
0 matig
0 slecht
0 zeer slecht

20. Wat is Uw burgerlijke staat?
0 gehuwd
0 samenwonend
0 nooit gehuwd of samenwonend geweest
0 gescheiden of niet meer samenwonend
0 weduwe of weduwnaar
0 anders, namelijk:

21. Wat is uw hoogstgenoten opleiding, waarvan $U$ een diploma heeft?

0 basisschool/lagere school

0 lager beroepsonderwijs

0 middelbaar algemeen onderwijs, zoals MULO, MAvo

0 middelbaar beroepsonderwijs

0 voortgezet algemeen onderwijs, zoals HBS, MMS, HAVO, Atheneum

0 hoger beroepsonderwijs

0 wetenschappelijk onderwijs

0 een andere opleiding, omschrijving:

22. Wat is op U van toepassing?
(eventueel meerdere hokjes aankruisen)
0 betaald werkend, 20 uur of meer per week
0 betaald werkend, minder dan 20 uur per week
0 werkloos
0 werkend in huishouden
0 schoolgaand
0 arbeidsongeschikt .......\% (percentage invullen)
0 gepensioneerd of VUT 
Opmerking voor de lezer:

Hierna volgen de VOEG-EN SIPlijsten, die in alle enquêteformulieren voor de patiënten steeds zijn opgenomen.

Om doublures te voorkomen zijn de lijsten in het proefschrift slechts eenmaal opgenomen.

\section{VOEG-lijst:}

Aanwijzing:

vraag 23 tot en met 35 gaan over allerlei lichamelijke klachten die voor het onderzoek van belang zijn. De uragen gaan over de periode van de afgelopen 6 maanden.

23. Hebt U nogal eens een opgezet of drukkend gevoel in uw maagstreek?
0 ja
0 nee

24. Bent U nogal eens duizelig?
0 ja
0 nee

25. Voelt U zich nogal eens lusteloos?
0 ja
0 nee

26. Hebt u nogal eens last van rugpijnen?
0 ja
0 nee

27. Hebt U nogal eens pijnen in uw borst of hartstreek?
$0 \mathrm{ja}$
0 nee

28. Staat $U$ in de regel 's ochtends moe en niet uitgerust op?
0 ja
0 nee

29. Hebt U nogal eens last van hoofdpijn?
0 ja
0 nee

30. Bent U gauw kortademig?
0 ja
0 nee 
31. Hebt $U$ wel eens een verdoofd gevoel of tintelingen in uw ledematen? 0 ja

0 nee

32. Hebt $\mathrm{U}$ vaak een gevoel van moeheid?

0 ja

0 nee

33. Is uw maag nogal van streek?

0 ja

0 nee

34. Hebt $U$ klachten over pijn in botten en spieren?

0 ja

0 nee

35. Bent $U$ sneller moe dan normaal?

0 ja

0 nee 
$\mathrm{Nu}$ volgt een groot aantal uitspraken waarmee de invloed van klachten, ziekte of handicap op het dagelijks functioneren kan worden vastgesteld. Wilt $U$ deze uitspraken beantwoorden zonder te pauzeren.

\section{INSTRUCTIE UITSPRAKENLIJST}

Leest $\mathrm{U}$ voordat $\mathrm{U}$ aan de vragenlijst begint de volgende aanwijzingen goed door.

\section{ALGEMENE AANWIJZINGEN}

Uw dagelijks leven bestaat uit verschillende bezigheden en aktiviteiten. Soms kunt $U$ die bezigheden onbelemmerd doen. Het kan echter zo zijn, dat $U$ een aantal van die bezigheden niet meer kunt doen op de manier zoals $U$ gewend bent, door Uw gezondheidstoestand of in verband met klachten, ziekte of handicap. Zo zult $U$ sommige bezigheden achterwege laten, met andere korter bezig zijn of ze op een andere manier doen.

De lijst die wij U vragen door te nemen bestaat uit uitspraken die betrekking hebben op veranderingen in uw dagelijkse aktiviteiten. Leest $U$ de uitspraken én voor één door en overweeg of een uitspraak op $U$ van toepassing is. Als $U$ een uitspraak tegen komt die op $U$ van toepassing is, ga dan vervolgens na of die te maken heeft met uw klachten of gezondheid. Als dat zo is, zet $U$ voór de uitspraak een kruisje en $U$ gaat verder met de volgende uitspraak.

\section{Voorbeeld:}

Een van de uitspraken luidt: 'Ik breng een groot deel van de dag zittend door'. Als vandaag deze uitspraak voor $U$ van toepassing is en dit samenhangt met uw klachten of gezondheid, dan kruist $U$ die uitspraak aan. $U$ doet het 6 ók als $U$ al langere tijd in verband met uw klachten of gezondheid een groot deel van de dag zittend doorbrengt, maar, als $U$ vandaag veel zit omdat $U$ toevallig van plan bent een boeiend boek uit te lezen, dan kruist $U$ deze uitspraak niet aan. Het een groot deel van de dag zitten heeft dan niets met uw klachten of gezondheid te maken.

\section{VUISTREGELS}

- De uitspraken kunnen (zowel) betrekking hebben op de veranderingen die pas kort geleden zijn opgetreden maar ook op een al wat langere tijd bestaande situatie.

- Kruist U alleen die uitspraken aan die samenhangen met uw gezondheid.

- Alleen uitspraken die volledig op $U$ van toepassing zijn moet $U$ aankruisen.

- Als een uitspraak slechts gedeeltelijk van toepassing is dan zet U geen kruisje.

U kunt nu beginnen met het doorlezen van de uitsprakenlijst. Lees in een rustig tempo. Als $U$ een uitspraak niet meteen begrijpt, wacht $U$ dan even zodat $U$ over de uitspraak na kunt denken. Lees deze vervolgens nog een keer.

Als $U$ tijdens het invullen van de uitsprakenlijst twijfelt of $U$ het wel of niet goed begrepen heeft, aarzel vooral niet, maar neem deze instructie nog een keer door. 
Beantwoordt $U$ alleen die uitspraken waarvan $U$ zeker weet dat zij op Uw huidige situatie van toepassing zijn en tevens samenhangen met Uw gezondheid.

\section{SLAPEN/RUSTEN}

O Ik breng een groot deel van de dag liggend door om te rusten.

O Ik breng een groot deel van de dag zittend door.

O Ik doezel bijna voortdurend weg.

O Ik ga overdag meer liggen rusten.

O Ik hang wat rond in half slapende toestand.

O Ik slaap 's nachts slechter

bv. ik word te vroeg wakker, het duurt lang voordat ik in slaap val, ik word vaak wakker.

O Ik slaap of dut meer overdag.

\section{EMOTIONEEL GEDRAG}

O Ik zeg maar steeds hoe minderwaardig of nutteloos ik ben.

O Ik kan zo maar in lachen of huilen uitbarsten.

O Ik klaag of kreun vaak van pijn of ongemak.

O Ik heb geprobeerd een eind aan mijn leven te maken.

O Ik doe nerveus of ben rusteloos.

O Ik zit maar steeds te wrijven of hou plekken vast waar mijn lichaam pijn doet of onprettig aanvoelt.

O Ik reageer geprikkeld en ongeduldig op mezelf

b.v. zeg slechte dingen over mezelf, vloek tegen mezelf, geef mezelf de schuld van dingen die gebeuren.

O Ik praat uitzichtloos over de toekomst.

O Ik krijg plotseling angsten.

\section{LICHAAMSVERZORGING EN BEWEGING}

$O$ Moelijke bewegingen voer ik alleen maar uit als iemand me helpt b.v. in- en uitstappen van auto's, bed.

O Ik kom niet zelf in of uit bed of stoel, maar wordt door iemand geholpen of door een of ander mechanisch hulpmiddel.

O Ik sta maar korte tijd achtereen.

O Ik kan mijn evenwicht niet bewaren.

O Ik kan mijn handen of vingers beperkt of moelijk bewegen.

O Ik kom alleen maar overeind als iemand mij helpt.

O Ik kan alleen maar knielen, hurken of bukken door mij aan iets vast te houden.

O Ik verander nauwelijks van lichaamshouding.

$O$ Ik ben onbeholpen in mijn bewegingen.

O Ik kom in en uit bed of stoel door een steun vast te pakken of door gebruik te maken van een stok of driepoot (rekje). 
O Ik blijf het grootste deel van de dag liggen.

O Ik verander vaak van houding.

O Ik houd me aan iets vast als ik me in bed wil verplaatsen

O Ik was mezelf helemaal niet, dat doet iemand anders

O Ik was mezelf niet helemaal, b.v. ik heb hulp nodig bij het in bad gaan.

O Ik maak gebruik van een beddepan/ondersteek met hulp.

O Ik heb geen controle over mijn blaas.

O Ik kan mijn ontlasting niet ophouden.

O Ik heb moeite met het aantrekken van schoenen, sokken of kousen.

O Ik maak mijn kleren niet vast, ik heb iemands hulp nodig bv. met knopen, ritssluiting, en schoenveters.

O Ik krijg mijn kleren alleen maar aan als iemand mij helpt.

O Ik kleed mijzelf wel aan, maar het gaat erg langzaam.

O Het grootste deel van de tijd breng ik gedeelrelijk aangekleed of in pyama door.

\section{HUISHOUDEN EN BEZIGHEDEN IN EN OM HET HUIS}

O Ik doe helemaal niets meer aan het gebruikelijke dagelijkse werk in en om het huis.

O Ik werk wel in en om het huis, maar korte tijd achtereen of ik rust vaak uit.

O Ik doe minder aan het gebruikelijke dagelijkse werk in en om het huis.

0 Ik verricht geen reparaties of onderhoudswerkzaamheden in huis of tuin die ik anders wel deed.

O Ik doe geen boodschappen die ik anders wel deed.

O Ik doe helemaal niets meer aan het schoonmaken.

$\mathrm{O}$ Ik heb moeite met dingen waarbij ik mijn handen gebruiken moet b.v. de kraan open en dicht draaien, omgaan met keukengerei, naaien, timmerwerk.

O Ik doe de was niet meer.

O Ik doe geen zwaar werk in en om het huis.

O Ik ben met de afhandeling van alle financiële, persoonlijke, of huishoudelijke zaken gestopt, b.v. rekeningen voldoen, gireren, huishoudboekje bijhouden.

\section{MOBILITEIT/VERPLAATSING}

O Ik verplaats me alleen binnenshuis (huis,flat).

O Ik verblijf in éen kamer.

O Ik blijf meer in bed liggen.

O Ik lig de meeste tijd in bed.

O Momenteel ga ik niet met het openbaar vervoer.

O Ik zit de meeste tijd thuis.

O Ik ga alleen naar gelegenheden waar een toilet in de buurt is.

O Ik ga de stad niet in.

O Ik ga alleen maar korte tijd van huis.

O Zonder iemands hulp kom ik niet in het donker of op onverlichte plaatsen. 


\section{LOPEN}

O Ik verplaats me met behulp van een rolstoel.

O Ik loop helemaal niet.

O Ik loop geen heuvels op en af.

O Ik loop alleen maar als iemand me erbij helpt.

O Ik verplaats me alleen maar met behulp van een drie- of vierpoot, krukken, stok, de wanden of door me aan meubels vast te houden.

O Ik loop kleinere afstanden of sta vaak stil om te rusten.

O Ik loop helemaal geen trappen.

O De trap oplopen doe ik alleen nog met hulpmiddlen, b.v. leuning, stok of krukken.

O Traplopen doe ik alleen maar met hulp van iemand anders.

O Ik loop weliswaar zonder hulp maar wel met enige moeite, b.v. ik loop kreupel, ik waggel, ik strompel, ik heb een stijf been.

O Ik loop de trap langzamer op en af, een trede tegelijk, ik sta vaak stil.

O Ik loop langzamer.

\section{RECREATIE EN VRIJE TIJD}

O Met mijn hobby's en andere ontspanningsactiviteiten houd ik me minder lang achtereen bezig.

O Ik ga minder vaak uit. bv. naar een concert, de schouwburg, de film, dansen, naar het cafe.

O Met sommige van mijn gebruikelijke passieve tijdsbestedingen doe ik het kalmer aan.

bv. tv. kijken, een spelletje kaarten, lezen.

O Ik doe niets aan mijn gebruikelijke passieve tijdsbesteding bv. tv. kijken, een spelletje kaarten, lezen.

O Ik doe meer aan passieve tijdsbesteding dan dat ik actief met iets bezig ben.

O Ik neem minder deel aan gemeenschapsactiviteiten bv. buurtwerk, vereniging, kerk.

O Ik doe het wat kalmer aan met sommige van mijn gebruikelijke lichamelijke activiteiten en ontspanning.

O Ik doe helemaal niets aan mijn gebruikelijke lichamelijke activiteiten en ontspanning. 


\section{Informatieve brief en vragenlijst voor de patiënt die na de randomisatie de gebruikelijke zorg krijgt. (Instroomconsult controlegroep).}

Geachte Mevrouw/Meneer,

Vandaag kwam U bij mij, uw huisarts, in verband met een klacht over het bewegingsapparaat. Dat wil zeggen, $U$ had last van de spieren, gewrichten of botten zoals dat bijvoorbeeld kan voorkomen bij rugpijn, pijn in de schouder of pijn in de knie, enkel, enzovoort. Ik heb U vervolgens onderzocht en voor deze klacht behandeld.

Het is voor $U$ belangrijk te weten dat ik deelneem aan een onderzoek van de Rijksuniversiteit Limburg en het Diagnostisch Centrum te Maastricht, waarbij wordt nagegaan op welke wijze huisartsen hun patiënten met klachten van het bewegingsapparaat het beste kunnen behandelen.

Om na te gaan hoe patiënten het beste behandeld worden is onderzoek naar de toestand van de patiënt en naar de mening daarover bij de patiënt van het grootste belang. Uw hulp is daarbij dus onontbeerlijk.

Wilt $U$ ons om die reden behulpzaam zijn bij het onderzoek. Wanneer $U$ erin toestemt kunt $U$ het volgende verwachten:

- een verzoek om de bijgaande vragenlijst over Uw gezondheidstoestand in te vullen en in bijgaande antwoord-enveloppe op te sturen.

- na én jaar een herhaling van het verzoek om de vragenlijst in te vullen en een gericht onderzoek naar Uw lichamelijke toestand, hetgeen gedaan zal worden door een orthopaedisch chirurg. Aan het onderzoek zijn voor $U$ vanzelfsprekend geen kosten verbonden.

- de gegevens van Uw behandeling vallen onder het medisch geheim en zullen derhalve vertrouwelijk worden behandeld.

$\mathrm{Na}$ één jaar zullen we dus opnieuw contact met $\mathrm{U}$ opnemen indien $\mathrm{U}$ nu aan het onderzoek deelneemt.

Bovendien willen wij $U$ hierbij bedanken voor $U w$ aandacht en eventuele medewerking.

Met vriendelijke groeten, 


\section{Patienten formulier B}

\section{Aanwijzingen:}

Vult $u$ deze vragenlijst liefst in op de dag dat u de huisarts bezoekt, maar zeker binnen twee dagen na het zien van de huisarts.

Nadat $u$ de lijst heeft ingevuld kunt u deze met de bijgevoegde antwoordenveloppe rechtstreeks naar de universiteit opsturen.

De vragenlijst bestaat uit twee delen:

- een eerste deel met een aantal vragen (37);

- een tweede deel met uitspraken over het dagelijkse functioneren.

Alle antwoorden die u geeft worden vertrouwelijk behandeld.

Het invullen van deze lijst neemt ongeveer 30 minuten in beslag.

Bij voorbaat onze hartelijke dank ! 


\section{Patiënten formulier B}

Naam huisarts:

Datum:

Naam:

Voornaam:

Geslacht: $\ldots \ldots \ldots \ldots \ldots$ Geboortedatum:

Adres:

Woonplaats:

Verzek. ZZL.no.:

E.R. Postcode:

Registratienummer:

1. Met welke klacht bent u bij de huisarts geweest?

2. Wanneer had U deze klacht voor het eerst?

0 korter dan 1 maand geleden

0 langer dan 1 maand, maar korter dan 6 maanden geleden

0 langer dan 6 maanden, maar korter dan 1 jaar geleden

0 langer dan 1 jaar geleden

3. Wanneer kwam u met deze klacht voor het eerst bij de huisarts?

0 korter dan 1 maand geleden

0 langer dan 1 maand, maar korter dan 6 maanden geleden

0 langer dan 6 maanden, maar korter dan 1 jaar geleden

0 langer dan 1 jaar geleden

4. Bent $\mathrm{u}$ behalve bij de huisarts nog bij andere artsen of therapeuten geweest?

0 nee

0 ja, bij de specialist; nl:

0 ja, bij de fysiotherapeur

$0 \mathrm{ja}$, bij een andere therapeut:

$0 \mathrm{ja}$, anders:

Aanwijzing: de vragen 5 tot en met 15 slaan op de situatie vóórdat $u$ bij uw huisarts kwam.

5. Had U last of hinder van de klacht?

0 zeer veel

0 veel

0 matig

0 weinig

0 geen 
6. Veroorzaakte de klacht pijn?
0 zeer veel
0 veel
0 matig
0 weinig
0 geen

7. Hoe ernstig dacht $U$ dat Uw klacht was?
0 heel ernstig
0 ernstig
0 niet zo heel ernstig
0 niet ernstig
0 helemaal niet ernstig

8. Verergert de klacht de laatste tijd?
0 zeer veel
0 veel
0 matig
0 weinig
0 niet

9. Maakte $U$ zich zorgen over deze klacht?
0 zeer veel
0 veel
0 matig
0 weinig
0 geen

10. Heeft u vanwege uw klacht uw aktiviteiten moeten beperken in de afgelopen 12 maanden?
- In uw werk?
0 ja
- In uw vrije tijds
0 nee
0 ja
0 nee

11. Hoeveel tijd in totaal heeft u vanwege uw klacht uw dagelijkse werkzaamheden niet kunnen doen de afgelopen 12 maanden?
0 o dagen
0 1 - 7 dagen
08 - 30 dagen
0 meer dan 30 dagen

12. Zijn naar uw mening het aantal sociale contacten (ontmoetingen met vrienden, kennissen, familie en buren) afgenomen de afgelopen 12 maanden? 0 ja, ga door met uraag 13

0 nee, ga door met vraag 14 
13. Houdt de afname in sociale contacten verband met uw klacht? 0 ja

0 nee

14. Wat had U verwacht dat Uw huisarts zou doen?

(eventueel meerdere hokjes aankruisen)

0 dat hij het zelf zou afhandelen (evt. met röntgen-foto's)

0 dat hij u zou verwijzen naar een specialist

0 dat hij u zou verwijzen naar een therapeut

(bv. fysiotherapie, Mensendieck, Cesar)

0 ik heb daar niet over nagedacht

0 weet ik niet

0 anders, nl.:

15. Wat wilde u zelf dat uw huisarts zou doen?

(eventueel meerdere hokjes aankruisen)

0 dat hij het zelf zou afhandelen (evt. met röntgenfoto's)

0 dat hij u zou verwijzen naar een specialist

0 dat hij u zou verwijzen naar een therapeut

(bv. fysiotherapie, Mensendieck, Cesar)

0 ik heb daar niet over nagedacht

0 weet ik niet

0 anders, nl.:

Aanwijzing: vraag 16 tot en met 24 slaan op de situatie nu, nadat $u$ bij de huisarts bent geweest.

16. Bent u i.v.m. uw klacht gerustgesteld?
0 volledig
0 voldoende
0 matig
0 weinig
0 niet

17. Heeft u voldoende aandacht gekregen?

0 ruim voldoende

0 voldoende

0 matig

0 weinig

0 geen 
18. Is het voor u duidelijk waardoor de klachten verooraakt worden?
0 volledig
0 voldoende
0 matig
0 weinig
0 niet

19. Is de therapie die $U$ kreeg voor $U$ voldoende duidelijk?

0 volledig

0 voldoende

0 matig

0 weinig

0 niet

20. Bent $U$ tevreden met de therapie welke $U$ kreeg?

0 volledig

0 voldoende

0 matig

0 weinig

0 niet

21. Hoe beoordeelt u uw eigen gezondheid als geheel?

0 zeer goed

0 goed

0 matig

0 slecht

0 zeer slecht

22. Wat is Uw burgerlijke staat?

0 gehuwd

0 samenwonend

0 nooit gehuwd of samenwonend geweest

0 gescheiden of niet meer samenwonend

0 weduwe of weduwnaar

0 anders, $\mathrm{nl}$.:

23. Wat is uw hoogstgenoten opleiding, waarvan $U$ een diploma heeft?

0 basisschool/lagere school

0 lager beroepsonderwijs

0 middelbaar algemeen onderwijs, zoals MULO, MAVO

0 middelbaar beroepsonderwijs

0 voortgezet algemeen onderwijs, zoals HBS, MMS, HAVO, Vwo

0 hoger beroepsonderwijs

0 wetenschappelijk onderwijs

0 een andere opleiding, omschrijving: $\ldots \ldots \ldots \ldots \ldots \ldots \ldots$ 
24. Wat is op U van toepassing?

(eventueel meerdere hokjes aankruisen)

0 betaald werkend, 20 uur of meer per week

0 betaald werkend, minder dan 20 uur per week

0 werkend in huishouden

0 schoolgaand

0 werkloos

0 arbeidsongeschikt ........\% (percentage invullen)

0 gepensioneerd of VuT

Hierna volgen de VOEG- en SIPlijsten 


\section{Vragenlijst voor de huisarts, waarvan de patiënt na} randomisatie deelneemt aan het gezamenlijk consult. (Instroomconsult interventiegroep). 
(Na de patiënt de eerste maal gezien te hebben, in te vullen door de huisarts)

Naam huisarts:

Datum:

Naam: ... . . . . . . . . Voornaam:

Geslacht: $\ldots \ldots \ldots \ldots \ldots$ Geboortedatum:

Adres: . . . . . . . . W Woonplaats:

Verzek. ZZL.no.: . . . . . . . E.R. Postcode:

Registratienummer:

1. Omschrijving klacht.

\section{Localisatie :}

2. Hoe lang heeft de patiënt deze klacht al, volgens u?

0 korter dan 1 maand geleden

0 langer dan 1 maand, maar korter dan 6 maanden geleden

0 langer dan 6 maanden, maar korter dan een jaar

0 langer dan 1 jaar geleden

3. Wanneer kwam de patiënt voor het eerst met deze klacht bij U?

0 korter dan 1 maand geleden

0 langer dan 1 maand, maar korter dan 6 maanden geleden

0 langer dan 6 maanden, maar korter dan een jaar

0 langer dan 1 jaar geleden

4. Hoeveel last of hinder denkt u dat de patiënt van deze klacht ondervindt?
0 zeer veel
0 veel
0 matig
0 weinig
0 geen

5. Hoeveel pijn denkt u dat de patiënt van deze klacht ondervindt?
0 zeer veel
0 veel
0 matig
0 weinig
0 geen 
6. Hoe ernstig denkt U dat de patiënt deze klacht vindt?

0 heel ernstig

0 ernstig

0 niet zo heel ernstig

0 niet ernstig

0 helemaal niet ernstig

7. Verergert de klacht de laatste tijd?

0 zeer veel

0 veel

0 matig

0 weinig

0 niet

8. Hoeveel zorgen denkt u dat de patiënt zich maakt over deze klacht?

0 zeer veel

0 veel

0 matig

0 weinig

0 niet

9. Wat denkt $\mathrm{u}$ dat de patiënt van u verwachtre?

0 dat $u$ het zelf zou afhandelen

0 dat $u$ zou verwijzen naar een specialist

0 dat u zou verwijzen naar een therapeut

0 De patiënt had geen verwachting

0 anders:

10. Heeft de patiënt eerder identieke klachten gehad?

0 ja, namelijk:

0 nee

11. Wilt $U$ in onderstaand overzicht aangeven welke diagnostische/ therapeutische handelingen inmiddels hebben plaatsgevonden?

0 röntgenfoto's, namelijk:

0 lab-onderzoek, namelijk:

0 algemene gezondheidsbevorderende adviezen (zwemmen, bewegen, etc.) namelijk:

0 medicatie, namelijk

0 injectie, punctie, namelijk: 
0 hulpmiddelen (supplementen, bandage, etc) namelijk:

0 fysiotherapie,

0 Cesartherapie,

0 Mensendiecktherapie,

0 verwijzing (anders dan orthopaed) voor deze klacht namelijk:

0 anders, namelijk:

12. Heeft deze patiënt overigens een chronische of langdurige ziekte of aandoening buiten deze klacht?

0 ja, namelijk:

0 nee

13. Voorlopige diagnose.

14. Hoe vaak komt een dergelijk diagnose voor in Uw huisartspraktijk?

0 zelden, naar schatting ........ $x$ per jaar

0 regelmatig, naar schatting ........... $x$ per jaar

0 vaak, naar schatting .......... $\mathrm{x}$ per jaar

15. Zijn er belangrijke psycho-sociale aspecten die bij deze klacht een rol spelen?

0 ja

0 nee

16. Verwacht $\mathrm{U}$ een belangrijke wijziging van de diagnose door het gezamenlijk consult?

(eventueel meerdere hokjes aankruisen)

$0 \mathrm{ja}$, door onderzoeksbevindingen

0 ja, door meer kennis en / of inzicht

0 ja, door:

0 nee

17. Verwacht $U$ een belangrijke wijziging van het plan door het gezamenlijk consult?

(eventueel meerdere hokjes aankruisen)

$0 \mathrm{ja}$, door een veranderde diagnose

0 ja, door meer kennis met betrekking tot een therapie

0 ja, namelijk door:

0 nee 
18. Verwacht $U$ dat deze patiënt na het gezamenlijk consult voor dit probleem naar een orthopaedisch chirurg verwezen zal worden?
0 ja
0 nee

19. Wat was de reden de patiënt voor het gezamenlijk consult in aanmerking te laten komen?
(eventueel meerdere hokjes aankruisen)
0 ik was onzeker over de diagnose
0 ik wilde zelf een second opinion
0 ik wilde kennisvermeerdering bij dit type probleem
0 ik wilde vaardigheden ontwikkelen bij dit type probleem
0 ik wilde een overbodige verwijzing voorkomen
0 ik wilde overleg in verband met te verwachten verwijzing
0 de patiënt maakte zich erg ongerust
0 de patiënt vroeg om verwijzing
0 ik wilde somatische fixatie voorkomen
0 anders, namelijk:

20. Wat zou $U$ doen indien het gezamenlijk consult niet mogelijk was?

(eventueel meerdere hokjes aankruisen)

0 ik zou zelf verder behandelen

0 ik zou nu meteen verwijzen naar een specialist, namelijk:

0 ik zou binnen afzienbare tijd verwijzen naar een specialist

0 ik zou röntgen-foto's aanvragen, namelijk:

0 ik zou laboratoriumonderzoek aanvragen, namelijk:

0 ik zou algemene gezondheidsbevorderende adviezen geven (zwemmen, bewegen, etc)

namelijk:

0 ik zou een medicatie geven, namelijk:

0 ik zou een injectie geven, punctie doen, namelijk:

0 ik zou een hulpmiddel geven (supplementen, bandage, etc) namelijk:

0 ik zou fysiotherapie adviseren

0 ik zou Cesartherapie adviseren

0 ik zou Mensendieck therapie adviseren

0 ik zou iets anders doen, namelijk:

Vult u tenslotte op de Vervolgkaart de aanmeldingsklacht in en de naam van de patiënt. 
Vragenlijst voor de huisarts, waarvan de patiënt na randomisatie de gebruikelijke zorg krijgt. (Instroomconsult controlegroep). 


\section{Huisarts formulier B}

(Na de patiënt de eerste maal gezien te hebben, in te vullen door de huisarts)

Naam huisarts:

Datum:

Naam: ............. Voornaam:

Geslacht: . . . . . . . Geboortedatum:

Adres: ............. Woonplaats:

Verzek. ZZL.no.: . . . . . . . E.R. Postcode:

Registratienummer:

1. Omschrijving klacht:

Localisatie:

2. Hoe lang heeft de patiënt deze klacht al, volgens u?

0 korter dan 1 maand

0 langer dan 1 maand, maar korter dan 6 maanden

0 langer dan 6 maanden, maar korter dan een jaar

0 langer dan 1 jaar

3. Wanneer kwam de patiënt voor het eerst met deze klacht bij U?

0 korter dan 1 maand geleden

0 langer dan 1 maand, maar korter dan 6 maanden geleden

0 langer dan 6 maanden, maar korter dan een jaar geleden

0 langer dan 1 jaar geleden

4. Hoeveel last of hinder denkt u dat de patiënt van deze klacht ondervindt?

0 zeer veel

0 veel

0 matig

0 weinig

0 geen

5. Hoeveel pijn denkt u dat de patiënt van deze klacht ondervindt?

0 zeer veel

0 veel

0 matig

0 weinig

0 geen 
6. Hoe ernstig denkt $U$ dat de patiënt deze klacht vindt?
0 heel ernstig
0 ernstig
0 niet zo heel ernstig
0 niet ernstig
0 helemaal niet ernstig

7. Verergert de klacht de laatste tijd?
0 zeer veel
0 veel
0 matig
0 weinig
0 niet

8. Hoeveel zorgen denkt $u$ dat de patiënt zich maakt over deze klacht?
0 zeer veel
0 veel
0 matig
0 weinig
0 niet

9. Wat denkt $u$ dat de patiënt van $u$ verwachtte?
0 dat $u$ het zelf zou afhandelen
0 dat u zou verwijzen naar een specialist
0 dat u zou verwijzen naar een therapeut
0 De patiënt had geen verwachting
0 anders:

10. Heeft de patiënt eerder identieke klachten gehad?
0 ja, namelijk:
0 nee

11. Wilt $U$ in onderstaand overzicht aangeven welke diagnostischel therapeutische handelingen inmiddels hebben plaatsgevonden?

0 röntgenfoto's, namelijk:

0 laboratoriumonderzoek, namelijk:
0 algemene gezondheidsbevorderende adviezen (zwemmen, bewegen, etc) namelijk:
0 medicatie, namelijk:
0 injectie, punctie, namelijk:



0 hulpmiddelen (supplementen, bandage, etc.) namelijk:
0 fysiotherapie,
0 Cesartherapie,
0 Mensendiecktherapie,
0 verwijzing (anders dan orthopaed) voor deze klacht namelijk:
0 anders, namelijk:

12. Heeft deze patiënt overigens een chronische of langdurige ziekte of aandoening buiten deze klacht?

0 ja, nl:

0 nee

13. Voorlopige diagnose.

14. Hoe vaak komt een dergelijk diagnose voor in Uw huisartspraktijk?

0 zelden, naar schatting ....... $x$ per jaar

0 regelmatig, naar schatting... .... $x$ per jaar

0 vaak, naar schatting ........ $\mathrm{x}$ per jaar

15. Zijn er belangrijke psycho-sociale aspecten die bij deze klacht een rol spelen? 0 ja

0 nee

16. Hoe is nu het plan?

17. Wilt $U$ in onderstaand overzicht aangeven welke diagnostische/therapeutische handelingen naar aanleiding van dit consult plaatsvinden?

0 geen verdere diagnostische/ therapeutische handelingen

0 röntgenfoto's, namelijk:

0 lab-onderzoek, namelijk:

0 algemene gezondheidsbevorderende adviezen (zwemmen, bewegen etc.), namelijk:

0 medicatie, namelijk:

0 injectie, punctie, namelijk: 

0 Hulpmiddelen (supplementen, bandages etc.), namelijk:
0 fysiotherapie,
0 Cesartherapie,
0 Mensendiecktherapie,
0 verwijzing naar een orthopaedisch chirurg,
0 verwijzing, anders dan orthopaedisch chirurg, namelijk:
0 anders, namelijk:

18. Zou $U$ een belangrijke wijziging verwachten van de diagnose door een gezamenlijk consult? (eventueel meerdere hokjes aankruisen)

$0 \mathrm{ja}$, door onderzoeksbevindingen

0 ja, door meer kennis en of inzicht

0 ja, door:

0 nee

19. Zou U een belangrijke wijziging verwachten van het plan door een gezamenlijk consult? (eventueel meerdere hokjes aankruisen)

0 ja, door een veranderde diagnose

0 ja, door meer kennis met betrekking tot een therapie

0 ja, namelijk door :

0 nee

20. Wat was de reden de patiënt voor het gezamenlijk consult in aanmerking te laten komen?

(eventueel meerdere hokjes aankruisen)

0 ik was onzeker over de diagnose

0 ik wilde zelf een second opinion

0 ik wilde kennisvermeerdering bij dit type probleem

0 ik wilde vaardigheden ontwikkelen bij dit type probleem

0 ik wilde een overbodige verwijzing voorkomen

0 ik wilde overleg in verband met te verwachten verwijzing

0 de patiënt maakte zich erg ongerust

0 de patiënt vroeg om verwijzing

0 ik wilde somatische fixatie voorkomen

0 anders, namelijk: 
Lichamelijk onderzoek B

Registratie nummer:

Datum:

1. Omschrijving klacht.

localisatie (evt. welk gewricht):

2. Is er zwelling van het betreffende lichaamsdeel?

0 ja

0 nee

3. Is er atrofie van het betreffende lichaamsdeel?

0 ja

0 nee

4. Is palpatie van het betreffende lichaamsdeel pijnlijk?

0 ja

0 nee

5. Is bewegen van het betreffende lichaamsdeel pijnlijk?

0 ja

0 nee

6. Is er een functie beperking van het betreffende lichaamsdeel?

0 ja, ga verder met vraag 7

0 nee, ga verder met vraag 12

7. Is de passieve beweeglijkheid bij én of meer testen beperkt?

$0 \mathrm{ja}$, aangeven in welkefuncties (flexie, extensie, abductie, adductie, endorotatie, exorotatie) en hoeveel in graden:

0 nee

8. Is de aktieve beweeglijkheid bij én of meer testen beperkt?

$0 \mathrm{ja}$, aangeven in welke functies (flexie, extensie, abductie, adductie, endorotatie, exorotatic) en hoeveel in graden:

0 nee 
9. Is de kracht van het betreffende lichaamsdeel beperkt?

0 ja

0 nee

10. Zijn er één of meer specifieke testen positief?

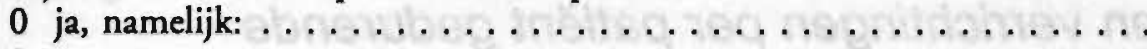

0 nee

11. In hoeverre is de funktie beperking het gevolg van de consultatie klacht?

0 volledig

0 ten dele, .........\%

0 niet

12. In welke categorie wat betreft lichamelijke zwaarte van dagelijkse werkzaamheden valt de patiënt?

0 zwaar

0 gemiddeld

0 licht

13. In hoeverre zijn eventuele beperkingen van de ADL-aktiviteiten het gevolg van de consultatieklacht?

0 volledig

0 ten dele:.........\%

0 niet

Vult u nu op de Vervolgkaart de aanmeldingsklacht en de naam van de patiënt in. 
Vervolglijst voor de huisarts, waarop alle bezoeken en verrichtingen per patiënt gedurende het onderzoeksjaar worden bijgehouden. (Interventie- en controlegroep). 


\section{Vervolgkaart}

Registratienummer. ............ Naam:

Aanmeldingsklacht:

Aanwijzing: deze vervolgkaart dient steeds ingevuld te worden wanneer de patiënt is behandeld (diagnostisch of therapeutisch) vanwege de aanmeldingsklacht

\begin{tabular}{|l|l|l|}
\hline & Bezoek ...datum... & Bezoek...datum.... \\
\hline Reden bezoek & & \\
\hline Diagnose & & \\
\hline $\begin{array}{l}\text { Onderzoek } \\
\text {-lab }\end{array}$ & & \\
\hline -rontgen & & \\
\hline $\begin{array}{l}\text { Therapie } \\
\text {-algemene adviezen }\end{array}$ & & \\
\hline -medicatie & & \\
\hline -injektie/punktie & & \\
\hline -lysiotherapie & & \\
\hline -CesarMensendiek & & \\
\hline -hulpmiddelen & & \\
\hline Verwilzing & & \\
\hline Herhaling Gezamenlijk Consult & & \\
\hline Anders & & \\
\hline
\end{tabular}


Vragenlijst voor de patient, na afloop van het gezamenlijk consult. (Interventiegroep). 
Patiēnten formulier A n

(na het gezamenlijk consult in te vullen door de patiënt)

Registratienummer: $\ldots \ldots \ldots \ldots$ Datum:

Naam:

1. Bent $U$ in verband met $U w$ klacht gerustgesteld?
0 volledig
0 voldoende
0 matig
0 weinig
0 niet

2. Heeft U voldoende aandacht gekregen?
0 zeer veel
0 veel
0 matig
0 weinig
0 geen

3. Is het voor $U$ duidelijk waardoor de klachten veroorzaakt worden?
0 volledig
0 voldoende
0 matig
0 weinig
0 niet

4. Is de behandeling of het advies die $\mathrm{U}$ kreeg voldoende duidelijk?
0 volledig
0 voldoende
0 matig
0 weinig
0 niet

5. Bent $U$ tevreden met de therapie welke $U$ kreeg?
0 volledig
0 voldoende
0 matig
0 weinig
0 niet 
Aanwijzing: Wat is uw mening over deze manier van samenwerking tussen huisarts en specialist?(vraag 6 tot en met 8)

6. Ik vind deze manier van samenwerken voor mij van belang.

0 volledig mee eens

0 mee eens

0 niet mee eens/ niet mee oneens

0 mee oneens

0 volledig mee oneens

7. Ik zou liever direct verwezen zijn naar de specialist.

0 volledig mee eens

0 mee eens

0 niet mee eens/ niet mee oneens

0 mee oneens

0 volledig mee oneens

8. Wat vindt $U$ van deze werkwijze?

(graag kort in uw eigen woorden aangeven) 


\section{Vragenlijst voor de huisarts,} na afloop van het gezamenlijk consult. (Interventiegroep). 
Huisarts formulier A n

(na het gezamenlijk consult in te vullen door de huisarts)

Registratienummer:

Datum:

Naam:

1. Diagnose:

2. Is de diagnose belangrijk gewijzigd door het gezamenlijk consult? (eventueel meerdere hokjes aankruisen)

$0 \mathrm{ja}$, door lichamelijk-onderzoeks-bevindingen

0 ja door lab/röntgen diagnostiek

0 ja, door meer kennis en / of inzicht

0 ja, anders:

0 nee

3. Hoe is nu het plan?

4. Is het plan belangrijk gewijzigd door het gezamenlijk consult? (eventueel meerdere hokjes aankruisen)

0 ja, door een veranderde diagnose

0 ja, door meer kennis met betrekking tot een therapie

0 ja, namelijk door:

0 nee

5. Wilt $U$ in onderstaand overzicht aangeven welke diagnostische/ therapeutische handelingen naar aanleiding van het gezamenlijk consult plaatsvinden?

0 geen verdere diagnostische/ therapeutische handelingen

0 röntgenfoto's, namelijk:

0 lab-onderzoek, namelijk:

0 algemene gezondheidsbevorderende adviezen (zwemmen, bewegen etc.), namelijk:

0 medicatie, namelijk: 
0 injectie, punctie, namelijk:

0 Hulpmiddelen (supplementen, bandages etc.), namelijk:

0 fysiotherapie,

0 Cesartherapie,

0 Mensendiecktherapie,

0 verwijzing naar een orthopaedisch chirurg,

0 verwijzing, anders dan orthopaedisch chirurg, namelijk:

0 anders, namelijk:

6. Is er een herhaling van het gezamenlijk consult afgesproken?

0 ja, over weken

0 nee

7. Wat is voor u de meerwaarde van het gezamenlijk consult? (eventueel meerdere hokjes aankruisen)

0 meer zekerheid over onderzoeksbevindingen

0 meer zekerheid over de diagnose

0 meer zekerheid over het plan

0 een zinvolle second opinion

0 kennisvermeerdering bij dit type probleem

0 vaardigheden ontwikkeld bij dit type probleem

0 een overbodige verwijzing voorkomen

0 belangrijk overleg in verband met te verwachten verwijzing

0 de patiënt is gerustgesteld

0 de patiënt is conform eigen wens verwezen

0 somatische fixatie voorkomen

0 anders, namelijk:

Aanwijzing: indien de patiënt via het gezamenlijk consult niet naar een orthopaedisch chirurg verwezen wordt, vraag 8 beantwoorden.

8. Verwacht $u$ dat de patiënt in de toekomst voor dit zelfde probleem toch nog verwezen zal worden?

0 ja

0 nee

0 twijfel 
Vragenlijst voor de orthopaedisch chirurg, na afloop van het gezamenlijk consult. (Interventiegroep). 
Specialisten formulier A $n$

(na het gezamenlijk consult in te vullen door de specialist)

Registratie nummer: . . . . . . Datum:

1. Omschrijving klacht ..........................

localisatie (evt. welk gewricht):

2. Is er zwelling van her betreffende lichaamsdeel?

0 ja

0 nee

3. Is er atrofie van het betreffende lichaamsdeel?

0 ja

0 nee

4. Is palpatie van het betreffende lichaamsdeel pijnlijk?

0 ja

0 nee

5. Is bewegen van het betreffende lichaamsdeel pijnlijk?

0 ja

0 nee

6. Is er een functie beperking van het betreffende lichaamsdeel?

0 ja, ga naar vraag 7

0 nee, ga naar vraag 12

7. Is de passieve beweeglijkheid bij én of meer testen beperkt?

0 ja, aangeven in welke functies (flexie, extensie, abductie, adductie, endorotatie, exorotatie) en hoeveel in graden:

0 nee

8. Is de aktieve beweeglijkheid bij én of meer testen beperkr?

$0 \mathrm{ja}$, aangeven in welke functies (flexie, extensie, abductie, adductie, endorotatie, exorotatie) en hoeveel in graden:

0 nee 
9. Is de kracht van het betreffende lichaamsdeel beperkt?

0 ja

0 nee

10. Zijn er één of meer specifieke testen positief?

0 ja, namelijk:

0 nee

11. In hoeverre is de funktie beperking het gevolg van de consultatie klacht?

0 volledig

0 ten dele, .........\%

0 niet

12. In welke categorie wat betreft lichamelijke zwaarte van dagelijkse werkzaamheden valt de patiënt?

0 zwaar

0 gemiddeld

0 licht

13. In hoeverre zijn eventuele beperkingen van de ADL-aktiviteiten het gevolg van de consultatieklacht?
$n$ volladig
0 ten dele:.........\%
0 niet

14. Kreeg je door de huisartsgeneeskundige inbreng, informatie waardoor je het beleid belangrijk liet beinvloeden?

0 ja

0 nee

15. Vind je dat de huisarts een dergelijk probleem zelfstandig kan behandelen?

0 ja

0 nee

0 anders, nl: 
Vragenlijst voor de patiënt, die vóór het onderzoek met huisarts en orthopaed moet worden ingevuld. (Eindconsult interventiegroep). 


\section{Patiënten formulier CTR-A}

\section{Aanwijzingen:}

De vragen hebben uitsluitend betrekking op de klacht, zoals vermeld op de begeleidende brief van uw huisarts.

Vult U deze vragenlijst liefst zo spoedig mogelijk in, maar in ieder geval vóór het onderzoek door de orthopaedisch chirurg in de huisartspraktijk.

De vragenlijst bestaat uit twee delen:

- een eerste deel met een aantal vragen.

- een tweede deel met uitspraken over het dagelijks functioneren.

Nadat $U$ de lijst heeft ingevuld, kunt $U$ deze met de bijgaande antwoordenveloppe rechtstreeks naar de universiteit sturen.

U hoeft geen postzegel te plakken.

Alle antwoorden die U geeft, worden vertrouwelijk behandeld.

Bij voorbaat onze hartelijke dank! 
Patiènten formulier CTR-A

(sticker patiënt gegevens)

Ruimte voor correcties/wijzigingen van bovenstaande gegevens:

1. Heeft $U$ de afgelopen 4 weken nog last of hinder van de klacht gehad?

0 Zeer veel

0 Veel

0 Matig

0 Weinig

0 Neen

2. Veroorzaakt(e) de klacht (de afgelopen 4 weken) nog pijn?

0 Zeer veel

0 Veel

0 Matig

0 Weinig

0 Neen

- Indien $U$ vraag 1 en 2 beide met 'neen' heeft beantwoord, kunt $U$ verder gaan met vraag 3

- In alle andere gevallen, doorgaan met vraag 5.

3. Is naar uw mening de klacht volledig verdwenen/genezen?

$0 \mathrm{Ja}$, de klacht is volledig verdwenen/genezen

0 Neen, de klacht is niet volledig verdwenen/genezen

ga naar vraag 4 ga naar vraag 5

4. Kunt $U$ aangeven sinds wanneer de klacht volledig verdwenen/genezen is?

Sinds ...weken/ maanden.

(Doorhalen wat niet van toepassing is)

$U$ kunt nu doorgaan met vraag 8

5. Hoe ernstig vindt $\mathrm{U}$ de klacht op dit moment?

0 Heel ernstig

0 Ernstig

0 Niet zo heel ernstig

0 Niet ernstig

0 Helemaal niet ernstig 
6. Is de klacht de laatste tijd

0 Aanzienlijk verergerd

0 Enigszins vergergerd

0 Nauwelijks verergerd

0 Hetzelfde gebleven

0 Nauwelijks verminderd

0 Enigszins verminderd

0 Aanzienlijk verminderd?

7. Maakt U zich nog zorgen over de klacht?

0 Zeer veel

0 Veel

0 Matig

0 Weinig

0 Geen

8. Heeft U vanwege de klacht uw aktiviteiten, geheel of gedeeltelijk, moeten beperken in de afgelopen 12 maanden?

A In uw (huishoudelijk) werk/school?

$0 \mathrm{Ja}$, geheel

$0 \mathrm{Ja}$, gedeelrelijk

0 Neen

B In uw vrije tijd?

$0 \mathrm{Ja}$, geheel

$0 \mathrm{Ja}$, gedeeltrelijk

0 Neen

- Indien $U$ vraag $8 A$ en $B$ beide met 'neen' heeft beantwoord, kunt $U$ verder gaan met vraag 12

- In alle andere gevallen doorgaan met vraag 9

9. Hoelang heeft $U$ vanwege de klacht uw aktivireiten, geheel of gedeeltelijk, niet kunnen uitoefenen de afgelopen 12 maanden?

01 week

02 tot 4 weken

01 tot 3 maanden

0 ... maanden

10. Is naar uw mening het aantal sociale contacten (ontmoetingen met vrienden, kennissen, familie en buren), gedurende kortere of langere tijd, afgenomen de afgelopen 12 maanden?

$0 \mathrm{Ja}, g a$ door met vraag 11

0 Neen, ga door met vraag 12 
11. Houdt de afname in sociale contacten verband met de klacht?
$0 \mathrm{Ja}$
0 Twijfel
0 Neen

12. Hoe beoordeelt $U$ uw eigen gezondheid als geheel?
0 Zeer goed
0 Goed
0 Matig
0 Slecht
0 Zeer slecht

13. Hebben er het afgelopen jaar nog belangrijke levensgebeurtenissen plaatsgevonden, zoals bijvoorbeeld scheiding, ziekte, ontslag, etc.?

$0 \mathrm{Ja}, \mathrm{ga}$ door met vraag 14

0 Neen, ga door met vraag 15

14. Hebben deze gebeurtenissen naar uw mening nog gevolg gehad voor de klacht?

$0 \mathrm{Ja}$

0 Twijfel

0 Neen

15. Hoe vaak bent $U$ voor deze klacht nog naar $U w$ huisarts geweest de afgelopen 12 maanden?

0 Geen enkele maal

0 1 1 - 2 maal

$03-4 \mathrm{maal}$

$05-6$ maal

0 Meer dan 6 maal

16. Heeft de huisarts na het onderzoek van de orthopaedisch chirurg van een jaar geleden voor deze klacht zelf nog onderzoeken verricht/laten verrichten? (Eventueel meer mogelijkheden aankruisen)

$0 \mathrm{Ja}$, hij heeft lichamelijk onderzoek verricht

hoe vaak

$0 \mathrm{Ja}$, mijn bloed is onderzocht

$0 \mathrm{Ja}$, mijn urine is onderzocht

$0 \mathrm{Ja}$, er zijn röntgen-foto's gemaakt

... keer

0 Weet niet

0 Neen

... keer

... keer

... keer 
17. Heeft de huisarts na het onderzoek van de orthopaedisch chirurg van een jaar geleden zelf voor deze klacht nog behandelingen verricht/laten verrichten? (Eventueel meer mogelijkheden aankruisen)

$0 \mathrm{Ja}$, hij heeft n.a.v. de klacht geneesmiddelen voor geschreven welke? hoe lang gebruikt(e) $\mathrm{U}$ ze?

$1 \ldots \ldots \ldots \ldots \ldots \ldots$ weken $/$ maanden* $^{*}$

$2 \ldots \ldots \ldots \ldots \ldots \ldots \ldots$ weken/maanden*

$3 \ldots \ldots \ldots \ldots \ldots \ldots \ldots$ weken $/$ maanden $^{*}$

4 weken/maanden*

$0 \mathrm{Ja}$, ik was/ben in behandeling bij een fysiotherapeut

$0 \mathrm{Ja}$, ik was/ben in behandeling bij een Cesartherapeut

aantal behandelingen ..... aantal behandelingen .....

$0 \mathrm{Ja}$, ik was/ben in behandeling bij een Mensendiecktherapeut

$0 \mathrm{Ja}$, ik was/ben in behandeling bij een manueel therapeut aantal behandelingen aantal behandelingen .....

$0 \mathrm{Ja}$, ik was/ben in behandeling bij een alternatieve genezer, nl.:

$0 \mathrm{Ja}$, anders, $\mathrm{nl}$ :

0 Neen

18. Bent $U$ naar aanleiding van deze klacht de afgelopen 12 maanden verwezen naar een orthopaedisch chirurg?

$0 \mathrm{Ja}$, ga naar uraag 19

0 Neen, ga naar vraag 21

19. Welk onderzoek heeft de orthopaedisch chirurg verricht/ingesteld? (Eventueel meer mogelijkheden aankruisen)

$0 \mathrm{Hij}$ heeft lichamelijk onderzoek verricht

0 Mijn bloed is onderzocht

0 Er zijn röntgen-foto's gemaakt

0 Weet niet

0 Geen

* Doorhalen wat niet van toepassing is 
20. Welke behandeling heeft de orthopaedisch chirurg voorgeschreven? (Eventueel meer mogelijkheden aankruisen)

$0 \mathrm{Hij}$ heeft geneesmiddelen voorgeschreven

0 Hij heeft behandeling door een fysiotherapeut voorgeschreven aantal behandelingen ....

0 Hij heeft behandeling door een Cesartherapeut voorgeschreven aantal behandelingen .....

0 Hij heeft behandeling door een Mensendiecktherapeut voorgeschreven aantal behandelingen .....

$0 \mathrm{Hij}$ heeft behandeling door een manueel therapeut voorgeschreven aantal behandelingen .....

21. Bent $U$ n.a.v. deze klacht in de afgelopen 12 maanden verwezen naar een reumatoloog?

$0 \mathrm{Ja}$

0 Neen

22. Bent $U$ naar aanleiding van deze klacht de afgelopen 12 maanden verwezen naar een neuroloog?

$0 \mathrm{Ja}$

0 Neen

Hierna volgen de vOEG- en sIPlijsten 
Vragenlijst voor de patiënt, die vóór het onderzoek met huisarts en orthopaed moet worden ingevuld. (Eindconsult controlegroep). 
Patiēnten formulier CTR-B

\section{Aanwijzingan:}

De vragen hebben uitsluitend betrekking op de klacht, zoals vermeld op de begeleidende brief van uw huisarts.

Vult $\mathrm{U}$ deze vragenlijst liefst zo spoedig mogelijk in, maar in ieder geval vóór het onderzoek door de orthopaedisch chirurg in de huisartspraktijk.

De vragenlijst bestaat uit twee delen:

- een eerste deel met een aantal vragen.

- een tweede deel met uitspraken over het dagelijks functioneren.

Nadat $U$ de lijst heeft ingevuld, kunt $U$ deze met de bijgaande antwoordenveloppe rechtstreeks naar de universiteit sturen.

U hoeft geen postzegel te plakken.

Alle antwoorden die $\mathrm{U}$ geeft, worden vertrouwelijk behandeld.

Bij voorbaat onze hartelijke dank! 
Patiënten formulier CTR-B

(sticker patiënt gegevens)

Ruimte voor correcties/wijzigingen van bovenstaande gegevens:

1. Heeft $U$ de afgelopen 4 weken nog last of hinder van de klacht gehad?

0 Zeer veel

0 Veel

0 Matig

0 Weinig

0 Neen

2. Veroorzaakt(e) de klacht (de afgelopen 4 weken) nog pijn?

0 Zeer veel

0 Veel

0 Matig

0 Weinig

0 Neen

- Indien $U$ vraag 1 en 2 beide met 'neen' heeft beantwoord, kunt $U$ verder gaan met vraag 3

- In alle andere gevallen, doorgaan met vraag 5.

3. Is naar uw mening de klacht volledig verdwenen/genezen?

$0 \mathrm{Ja}$, de klacht is volledig verdwenen/genezen

0 Neen, de klacht is niet volledig verdwenen/genezen

ga naar vraag 4

ga naar vraag 5

4. Kunt $U$ aangeven sinds wanneer de klacht volledig verdwenen/genezen is? Sinds ...weken/maanden. (Doorhalen wat niet van toepassing is)

$U$ kunt nu doorgaan met vraag 8

5. Hoe ernstig vindt $\mathrm{U}$ de klacht op dit moment?

0 Heel ernstig

0 Ernstig

0 Niet zo heel ernstig

0 Niet ernstig

0 Helemaal niet ernstig 
6. Is de klacht de laatste tijd

0 Aanzienlijk verergerd

0 Enigszins verergerd

0 Nauwelijks verergerd

0 Hetzelfde gebleven

0 Nauwelijks verminderd

0 Enigszins verminderd

0 Aanzienlijk verminderd?

7. Maakt U zich nog zorgen over de klacht?

0 Zeer veel

0 Veel

0 Matig

0 Weinig

0 Geen

8. Heeft $U$ vanwege de klacht uw aktiviteiten, geheel of gedeeltelijk, moeten beperken in de afgelopen 12 maanden?

A In uw (huishoudelijk) werk/school?

$0 \mathrm{Ja}$, geheel

$0 \mathrm{Ja}$, gedeeltelijk

0 Neen

B In uw vrije tijd?

0 Ja, geheel

$0 \mathrm{Ja}$, gedeeltrelijk

0 Neen

- Indien $U$ vraag $8 A$ en $B$ beide met 'neen' heeft beantwoord, kunt $U$ verder gaan met vraag 12

- In alle andere gevallen doorgaan met vraag 9

9. Hoelang heeft $U$ vanwege de klacht uw aktiviteiten, geheel of gedeeltelijk, niet kunnen uitoefenen de afgelopen 12 maanden?

01 week

02 tot 4 weken

01 tot 3 maanden

0 ... maanden

10. Is naar uw mening het aantal sociale contacten (ontmoetingen met vrienden, kennissen, familie en buren), gedurende kortere of langere tijd, afgenomen de afgelopen 12 maanden?

$0 \mathrm{Ja}$, ga door met vraag 11

0 Neen, ga door met vraag 12 
11. Houdt de afname in sociale contacten verband met de klacht?
$0 \mathrm{Ja}$
0 Twijfel
0 Neen

12. Hoe beoordeelt $U$ uw eigen gezondheid als geheel?
0 Zeer goed
0 Goed
0 Matig
0 Slecht
0 Zeer slecht

13. Hebben er het afgelopen jaar nog belangrijke levensgebeurrenissen plaatsgevonden, zoals bijvoorbeeld scheiding, ziekte, ontslag, etc.?

$0 \mathrm{Ja}, \mathrm{ga}$ door met vraag 14

0 Neen, ga door met uraag 15

14. Hebben deze gebeurtenissen naar uw mening nog gevolg gehad voor de klacht?
$0 \mathrm{Ja}$
0 Twijfel
0 Neen

15. Hoe vaak bent $U$ voor deze klacht nog naar Uw huisarts geweest de afgelopen 12 maanden?

0 Geen enkele maal

0 1 1 - 2 maal

03 - 4 maal

0 5 - 6 maal

0 Meer dan 6 maal

16. Heeft de huisarts n.a.v. de klacht van een jaar geleden gedurende de afgelopen 12 maanden zelf nog onderzoeken verricht/laten verrichten? (Eventueel meer mogelijkheden aankruisen)

$0 \mathrm{Ja}$, hij heeft lichamelijk onderzoek verricht

boe vaak

$0 \mathrm{Ja}, \mathrm{mijn}$ bloed is onderzocht

.... keer

$0 \mathrm{Ja}, \mathrm{mijn}$ urine is onderzocht

.... keer

$0 \mathrm{Ja}$, er zijn röntgen-foto's gemaakt

.... keer

0 Weet niet

0 Neen 
17. Heeft de huisarts n.a.v. de klacht van een jaar geleden gedurende de afgelopen 12 maanden zelf nog behandelingen verricht/laten verrichten?

(Eventueel meer mogelijkheden aankruisen)

0 Ja, hij heeft n.a.v. de klacht geneesmiddelen voorgeschreven welke? hoe lang gebruikt(e) $\mathrm{U}$ ze?

1

2

3 weken/maanden

$\ldots \ldots \ldots \ldots \ldots$
$\ldots \ldots \ldots \ldots \ldots$ weken/maanden*

4 weken/maanden* weken/maanden*

$0 \mathrm{Ja}, \mathrm{ik}$ was/ben in behandeling bij een fysiotherapeut

$0 \mathrm{Ja}, \mathrm{ik}$ was/ben in behandeling bij een Cesartherapeut aantal behandelingen ..... aantal behandelingen

$0 \mathrm{Ja}$, ik was/ben in behandeling bij een Mensendieck-therapeut

$0 \mathrm{Ja}$, ik was/ben in behandeling bij een manueel therapeut aantal behandelingen ..... aantal behandelingen .....

$0 \mathrm{Ja}$, ik was/ben in behandeling bij een alternatieve genezer, $\mathrm{nl} .: \ldots \ldots$

$0 \mathrm{Ja}$, anders, $\mathrm{nl}$ :

0 Neen

18. Bent $U$ naar aanleiding van deze klacht de afgelopen 12 maanden verwezen naar een orthopaedisch chirurg?

0 ja, ga naar vraag 19

0 neen, ga naar vraag 21

19. Welk onderzoek heeft de orthopaedisch chirurg verricht/ingesteld?

(Eventueel meer mogelijkheden aankruisen)

$0 \mathrm{Hij}$ heeft lichamelijk onderzoek verricht

0 Mijn bloed is onderzocht

0 Er zijn röntgen-foto's gemaakt

0 Weet niet

0 Geen

* Doorhalen wat niet van toepassing is 
20. Welke behandeling heeft de orthopaedisch chirurg voorgeschreven? (Eventueel meer mogelijkheden aankruisen)

$0 \mathrm{Hij}$ heeft geneesmiddelen voorgeschreven

$0 \mathrm{Hij}$ heeft behandeling door een fysiotherapeut voorgeschreven aantal behandelingen .....

0 Hij heeft behandeling door een Cesartherapeut voorgeschreven aantal behandelingen .....

0 Hij heeft behandeling door een Mensendiecktherapeut voorgeschreven aantal behandelingen .....

0 Hij heeft behandeling door een manueel therapeut voorgeschreven aantal behandelingen

21. Bent $U$ n.a.v. deze klacht in de afgelopen 12 maanden verwezen naar een reumatoloog?

$0 \mathrm{Ja}$

0 Neen

22. Bent $U$ naar aanleiding van deze klacht de afgelopen 12 maanden verwezen naar een neuroloog?

$0 \mathrm{Ja}$

0 Neen

Hierna volgen de VOEG- en sIPlijsten. 
Vragenlijst voor de huisarts, die na het onderzoek van huisarts en orthopaed moet worden ingevuld. (Eindconsult interventiegroep). 


\section{Huisarts formulier CTR-A}

In te vullen na het controle-onderzoek van de orthopaedisch chirurg. (sticker patiënt gegevens)

1. Omschrijving diagnose van 1 jaar geleden:

2. Heeft de patiënt nog klachten, samenhangend met bovenstaande diagnose?
$0 \mathrm{Ja}$
0 Neen
0 Weet niet

3. Zijn er naar uw mening voor deze patiënt belangrijke gebeurtenissen geweest, die een rol hebben gespeeld in het ziektebeeld/verloop?
$0 \mathrm{Ja}, \mathrm{nl}$ :
0 Twijfel
0 Neen
0 Weet niet

4. Heeft het Gezamenlijk Consult bij deze patiënt aan uw verwachtingen voldaan?
0 Ja
0 Twijfel
0 Neen

5. Heeft $U$ een patiënt met een identiek probleem als van deze patiënt na het Gezamenlijk Consult op uw spreekuur gezien?
$0 \mathrm{Ja}$
0 Neen
verder met vraag 6
verder met uraag 11

6. Heeft U een dergelijke pariënt zelfstandig behandeld?
$0 \mathrm{Ja}$
0 Twijfel verder met uraag 7
0 Neen verder met uraag 7 verder met uraag 10

7. Vindt $U$ dit een gevolg van toegenomen kennis en/of vaardigheden opgedaan in of n.a.v. het Gezamenlijk Consult?
$0 \mathrm{Ja}$
0 Twijfel
0 Neen 
8. Hoeveel patiënten met identieke problemen/diagnoses heeft U sindsdien zelfstandig behandeld? (naar schatting) patiënten

9. Indien $U$ een patiënt met een identiek probleem nu zelfstandig behandelt, wat is volgens $U$ dan de reden van deze verandering?

(eventueel meer mogelijkheden aankruisen)

0 Ik beschik nu over meer kennis

0 Ik kan gegevens beter interpreteren

0 Ik vraag gerichter diagnostiek aan

0 Mijn diagnostische handelingen zijn verbeterd

0 Mijn therapeutische behandelingen zijn verbeterd, b.v. injectie, punctie)

0 Ik heb hierbij geen second opinion meer nodig

0 Ik kan de patiënt nu beter geruststellen

0 Ik ben van mening dat de specialist niet meer te bieden heeft

0 Anders, $\mathrm{nl}$ :

0 Weet niet

\section{Doorgaan met vraag 11}

10. Indien $U$ een patiënt met een identiek probleem niet zelfstandig behandelt, wat is daarvan de reden?

(eventueel meer mogelijkbeden aankruisen)

0 Ik ben van mening dat een dergelijke patiënt beter verwezen kan worden

0 Ik ontkom niet aan de vraag van een second opinion

0 Ik vind, dat ik de wens van de patiënt tot verwijzing moet honoreren

0 Mijn diagnostische mogelijkheden zijn te beperkt voor dit probleem

0 Mijn behandelingsmogelijkheden zijn te beperkt voor dit probleem

0 Voor een dergelijk probleem is het Gezamenlijk Consult steeds de beste oplossing

0 Anders, nl.

11. Vindt $U$ dat deze patiënt adequaat behandeld is?
$0 \mathrm{Ja}$
0 Twijfel
0 Neen - waarom niet?
0 Weet niet

12. Is bij de patiënt in relatie tot de klacht evidente pathologie gevonden?

$0 \mathrm{Ja}$

0 Neen 
Vragenlijst voor de huisarts, die na het onderzoek van huisarts en orthopaed moet worden ingevuld. (Eindconsult controlegroep). 
Huisarts formulier CTR-B

In te vullen na het controle-onderzoek van de orthopaedisch chirurg.

(sticker patiënt gegevens)

1. Omschrijving diagnose van 1 jaar geleden: $\ldots \ldots \ldots \ldots \ldots \ldots \ldots \ldots$

2. Heeft de patiënt nog klachten, samenhangend met bovenstaande diagnose?

$0 \mathrm{Ja}$

0 Neen

0 Weet niet

3. Zijn er naar uw mening voor deze patiënt belangrijke gebeurtenissen geweest, die een rol hebben gespeeld in het ziektebeeld/verloop?

$0 \mathrm{Ja}, \mathrm{nl}$ :

0 Twijfel

0 Neen

0 Weet niet

4. Betreurt $U n u$ het feit, dat $U$ bij deze patiënt door de randomisatie-methode geen gebruik heeft kunnen maken van het Gezamenlijk Consult?
$0 \mathrm{Ja}$
0 Twijfel
0 Neen
verder met vraag 5
verder met vraag 5
verder met uraag 6

5. Achteraf gezien vind ik het jammer dat:

(Eventueel meer mogelijkheden aankruisen)

0 Ik geen second opinion kon krijgen

0 Ik geen kennisvermeerdering bij dit type probleem kon krijgen

0 Ik mijn vaardigheden niet kon ontwikkelen bij dit type probleem

0 De patiënt mijn inziens overbodig verwezen werd

0 Ik niet kon overleggen in verband met een voorgenomen verwijzing

0 Ik de patiënt niet voldoende gerust kon stellen

0 Ik somatische fixatie niet kon voorkomen

0 Anders, nl.: 
6. Heeft $U$ in het voorbije jaar bij de begeleiding van deze patiënt voor bovenstaande diagnose gebruik kunnen maken van kennis en/of vaardigheden die U opdeed bij een Gezamenlijk Consult?
$0 \mathrm{Ja}$,
0 Twijfel,
0 Neen,

verder met uraag 7

verder met vraag 7

verder met vraag 8

7. Kunt $U$ aangeven wat de reden van deze verandering is?

(Eventueel meer mogelijkheden aankruisen)

0 Ik beschik nu over meer kennis

0 Ik kan gegevens beter interpreteren

0 Ik vraag gerichter diagnostiek aan

0 Mijn diagnostische handelingen zijn verbeterd

0 Mijn therapeutische behandelingen zijn verbeterd (b.v. injectie, punctie)

0 Ik heb hierbij geen second opinion meer nodig

0 Ik kan de patiënt nu beter geruststellen

0 Ik ben van mening dat de specialist niet meer te bieden heeft

0 Anders, $\mathrm{nl}$ :

0 Weet niet

8. Stel dat $U$ een identiek probleem bij een identieke patiënt aantreft, zou $U$ hem dan $n u$ zelfstandig behandelen?
$0 \mathrm{Ja}$
0 Twijfel
0 Neen

verder met vraag 9

verder met vraag 9

verder met vraag 11

9. Komt dat door toegenomen kennis en/of vaardigheden van voorgaande Gezamenlijke Consulten?
$0 \mathrm{Ja}$
0 Twijfel
0 Neen

10. Indien $U$ een patiënt met een identiek probleem $n u$ zelfstandig zou behandelen, wat is volgens $U$ dan de reden van deze verandering?

(Eventueel meer mogelijkheden aankruisen)

0 Ik beschik nu over meer kennis

0 Mijn diagnostische handelingen zijn verbeterd

0 Mijn therapeutische behandelingen zijn verbeterd (b.v. injectie, punctie)

0 Ik kan gegevens beter interpreteren

0 Ik vraag gerichter diagnostiek aan

0 Ik ben van mening dat de specialist niet meer te bieden heeft

0 Ik heb hierbij geen second opinion meer nodig

0 Ik kan de patiënt nu beter geruststellen

0 Anders, nl.:

0 Weet niet 
Ga verder met vraag 12

11. Indien $U$ een patiënt met een identiek probleem niet zelfstandig zou behandelen, wat is daarvan de reden?

(Eventueel meer mogelijkheden aankruisen)

0 Ik ben van mening dat een dergelijke patiënt beter verwezen kan worden

0 Ik ontkom niet aan de vraag van een second opinion

0 Ik vind dat ik de wens van de patiënt tot verwijzing moet honoreren

0 Mijn diagnostische mogelijkheden zijn te beperkt voor dit probleem

0 Mijn behandelingsmogelijkheden zijn te beperkt voor dit probleem

0 Voor een dergelijk probleem is het Gezamenlijk Consult steeds de beste oplossing

0 Anders, nl.:

12. Vindt $U$ dat de patiënt adequaat behandeld is?
$0 \mathrm{Ja}$
0 Twijfel

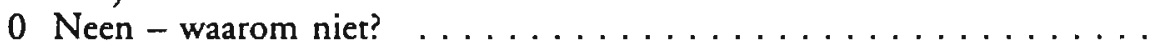

13. Is bij deze patiënt in relatie tot de klacht evidente pathologie gevonden?
$0 \mathrm{Ja}$
0 Neen 
Vragenlijst voor de orthopaedisch chirurg, die na het onderzoek van huisarts en orthopaed moet worden ingevuld.

(Eindconsult interventie- en controlegroep). 
Specialisten formulier CTR-A

(sticker patiënt gegevens)

Omschrijving diagnose van 1 jaar geleden:

1. Omschrijving klacht:

\section{0 klacht afwezig}

2. Is er zwelling van het betreffende lichaamsdeel?

0 ja

0 neen

3. Is er atrofie van het betreffende lichaamsdeel?

0 ja

0 neen

4. Is palpatie van het betreffende lichaamsdeel pijnlijk?

0 ja

0 neen

5. Is bewegen van het betreffende lichaamsdeel pijnlijk?

0 ja

0 neen

6. Is er een functie beperking van het betreffende lichaamsdeel?
$0 \mathrm{ja}$, ga naar vraag 7
0 neen,
ga naar vraag 12

7. Is de passieve beweeglijkheid bij éen of meer testen beperkt?
$0 \mathrm{ja}$, aangeven in welke functies (flexie, extensie,abductie, adductie, endoro- tatie, exorotatie) en hoeveel graden:
0 neen

8. Is de aktieve beweeglijkheid bij één of meer testen beperkt?

$0 \mathrm{ja}$, aangeven in welke functies (flexie, extensie, abductie, adductie, endorotatie, exorotatie) en hoeveel graden:

0 neen 
9. Is de kracht van het betreffende lichaamsdeel beperkt?
0 ja
0 neen

10. Zijn er één of meer specifieke testen positief?
0 ja, namelijk:
0 neen

11. In hoeverre is de funktie beperking het gevolg van de consultatie klacht?
0 volledig
0 ten dele, ...\%
0 nier

12. In welke categorie wat betreft lichamelijke zwaarte van dagelijkse werkzaamheden valt de patiënt?

0 zwaar

0 gemiddeld

0 licht

13. In hoeverre zijn eventuele beperkingen van de ADL-aktiviteiten het gevolg van de consultatieklacht?

0 volledig

0 ten dele:....\%

0 niet

14. Indien de klacht nog aanwezig is; wat is nu de diagnose?

15. Is deze diagnose afwijkend van 1 jaar geleden?
0 zo ja;
0 sterk afwijkend
0 licht afwijkend
0 neen

16. Vindt $U$ verdere specialistische behandeling nog op zijn plaats?

0 ja

0 neen 
Vragenlijst voor de huisarts over zijn ervaringen met het gezamenlijk consult. 
Deze vragen hebben betrekking op de Gezamenlijke Consulten.

\section{ORGANISATIE}

- Aantal gezamenlijke consulten:

- Verliep de planning van de Gezamenlijk Consulten spreekuren eenvoudig? 0 ja

0 nee

0 anders:

- Vonden de Gezamenlijk Consult spreekuren plaats in de eigen praktijk?

0 ja

0 nee

Indien nee: Vond je het bezwaarlijk, dat de Gezamenlijk Consult spreekuren niet in de eigen prakrijk gehouden werden?

0 ja

0 nee

Indien ja: Waarom?:

- Betekende de spreekuren een zware belasting voor je?

0 ja

0 nee

- Een tijdsbesteding van ..... uur per 2 weken voor een Gezamenlijk Consult is voor mij het maximaal haalbare.

- Per uur Gezamenlijk Consult zijn ..... patiënten optimaal te behandelen.

- Zou je aan een Gezamenlijk Consult willen blijven deelnemen:

A. voor andere specialismen?

0 ja

0 nee

Indien ja: welke specialisme(n) lijk(en) je zinvol?

B. om orthopaedie nog enige tijd te vervolgen?

$0 \mathrm{ja}$

0 nee

- Zijn er spreekuren uitgevallen?:

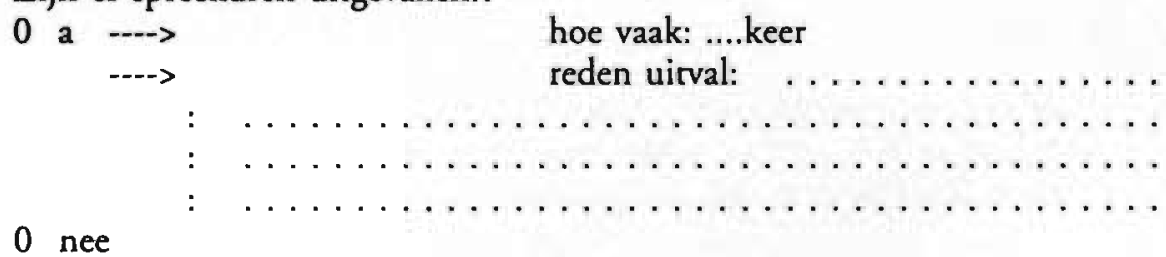


WELKE DOELEN

Wat vond je het meest belangrijk bij het Gezamenlijk Consult?:

-kennistoename:

$\begin{aligned} & \text { volledig mee eens } \\
& \text { mee eens }\end{aligned}$
\begin{tabular}{|l|l|l|l|l|}
\hline & $\begin{array}{l}\text { noch eens/ noch oneens } \\
\text { oneens }\end{array}$ & & \\
\hline
\end{tabular}

-betere interpretatie van de gegevens:

\begin{tabular}{l}
$\begin{array}{l}\text { volledig mee eens } \\
\text { mee eens }\end{array}$ \\
\begin{tabular}{|l|l|l|l|l|}
\hline & $\begin{array}{l}\text { noch eens/ noch oneens volledig oneens } \\
\text { oneens }\end{array}$ \\
\hline
\end{tabular} \\
\hline
\end{tabular}

-huisarts kan beter gerichte diagnostiek aanvragen:

$\begin{array}{lll}\text { volledig mee eens noch eens/ noch oneens } & \text { volledig oneens } \\ \text { mee eens } & \end{array}$

\begin{tabular}{|l|l|l|l|l|}
\hline & & & & \\
\hline
\end{tabular}

- onderzoeksvaardigheden verbeteren:

$\begin{aligned} & \text { volledig mee eens } \\
& \text { mee eens }\end{aligned}$
\begin{tabular}{|l|l|l|l|l|}
\hline & \multicolumn{1}{l}{$\begin{array}{l}\text { noch eens/ noch oneens volledig oneens } \\
\text { oneens }\end{array}$} \\
\hline
\end{tabular}

-therapeutische behandeling verbeteren:

\begin{tabular}{l}
$\begin{array}{l}\text { volledig mee eens } \\
\text { moe eens }\end{array}$ \\
\hline
\end{tabular}

-instelling van second opinion:

\begin{tabular}{l}
$\begin{array}{l}\text { volledig mee eens } \\
\text { mee eens }\end{array}$ \\
\begin{tabular}{|l|l|l|l|l|}
\hline & $\begin{array}{l}\text { noch eens/ noch oneens } \\
\text { oneens }\end{array}$ & & \\
\hline
\end{tabular} \\
\hline
\end{tabular}


-betere geruststelling van patiënt:

\begin{tabular}{l}
$\begin{array}{l}\text { volledig moe cens } \\
\text { mee eens }\end{array}$ \\
\hline
\end{tabular}

-het voorkomen van onnodige verwijzingen:

\begin{tabular}{l}
$\begin{array}{l}\text { volledig mee eens } \\
\text { mee oens }\end{array}$ \\
\hline
\end{tabular}

-het voorkomen van onnodige verrichtingen?:

\begin{tabular}{l|l|l|l|l|}
$\begin{array}{l}\text { volledig mee eens } \\
\text { mee eens }\end{array}$ & $\begin{array}{l}\text { noch eens/ noch oneens } \\
\text { oneens }\end{array}$ & \multicolumn{2}{c|}{ volledig oneens } \\
\hline & & & & \\
\hline
\end{tabular}

-ter voorbespreking bij verwijzing met complexe problematiek:

$\begin{array}{llll}\begin{array}{l}\text { volledig mee eens } \\ \text { mee eens }\end{array} & \begin{array}{l}\text { noch eens/ noch oneens } \\ \text { oneens }\end{array}\end{array}$

\begin{tabular}{|l|l|l|l|l|}
\hline & & & & \\
\hline
\end{tabular}

-anders: 


\begin{tabular}{|l|l|}
\hline Rapportclifer van 1 Vm 10 & Cijler \\
\hline \hline Kennlstoeneme hulsarts & \\
\hline Betere interpretatie van de gegevens & \\
\hline Huisarts kan beter gerichte diagnostiek aanvragen & \\
\hline Onderzoeksvaandigheden verbeteren & \\
\hline Therapeutlsche behandeling verbeteren & \\
\hline Instelling van second opinion & \\
\hline Belere geruststelling van patient & \\
\hline Voorkomen van onnodige verwijzingen & \\
\hline Voorkomen van onnodige verrichtingen & \\
\hline Ter voorbespreking bij verwijzing met complexe problematiek & \\
\hline
\end{tabular}

\section{ERVARINGEN HUISARTSEN}

- Tijdens het Gezamenlijk Consult werd mijn beleid minder sterk gestuurd door defensieve motieven:

\begin{tabular}{l|l|l|l|l|}
$\begin{array}{l}\text { volledig mee eens } \\
\text { mee eens }\end{array}$ & $\begin{array}{l}\text { noch eens/ noch oneens } \\
\text { oneens }\end{array}$ & & & \\
\hline & & & & \\
\hline
\end{tabular}

- Door de ervaring van het Gezamenlijk Consult is mijn inzicht over de orthopaedie belangrijk veranderd:

\begin{tabular}{l}
$\begin{array}{l}\text { volledig mee eens } \\
\text { mee oens }\end{array}$ \\
\hline
\end{tabular}

- Het was voor mij niet moeilijk om de eigen onmogelijkheden te erkennen:

$\begin{aligned} & \text { volledig mee eens noch eens/ noch oneens voliedig oneens } \\ & \text { mee eens }\end{aligned}$
oneens

\begin{tabular}{|l|l|l|l|l|}
\hline & & & & \\
\hline
\end{tabular}

- Het was voor mij niet moeilijk om mijn gevoerd beleid aan de collegae te exploiteren:

\begin{tabular}{l}
$\begin{array}{l}\text { volledig mee eens } \\
\text { mee eens }\end{array} \quad \begin{array}{l}\text { noch eens/ noch oneens volledig oneens } \\
\text { oneens }\end{array}$ \\
\hline
\end{tabular}

\begin{tabular}{|l|l|l|l|l|}
\hline & & & & \\
\hline
\end{tabular}


- Het Gezamenlijk Consult ervoer ik als een prettige taak:

- Het aspect "nascholing" gaf mij veel voldoening bij het Gezamenlijk Consult:

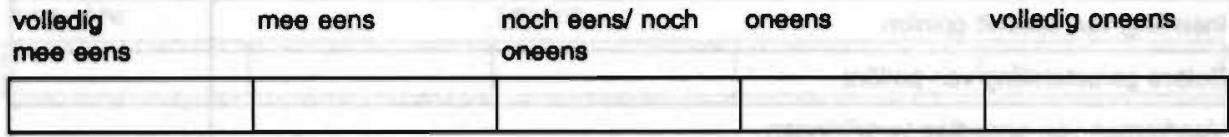

\section{Gewerensvraag:}

- Randomisatie is een moeilijk gegeven.

Hoe vaak de hand er mee gelicht?

- Eigen opmerkingen: 
Vragenlijst voor de orthopaedisch chirurg over zijn ervaringen met het gezamenlijk consult. 
Deze vragen hebben betrekking op de Gezamenlijke Consulten.

Naam orthopaed:

\section{ORGANISATIE}

- Aantal gezamenlijke consulten:

- Verliep de planning van de Gezamenlijk Consulten spreekuren met de huisartsen eenvoudig?

0 a

0 nee

0 anders

- Betekende de spreekuren een zware belasting voor je?

0 ja

0 nee

- Een tijdsbesteding van ..... uur per 2 weken voor een Gezamenlijk Consult is voor mij het maximaal haalbare.

- Per uur Gezamenlijk Consult zijn ..... patiënten optimaal te behandelen.

- Zou je aan een Gezamenlijk Consult willen blijven deelnemen voor nieuwe groepen huisartsen?

$0 \mathrm{ja}$

0 nee

- Identieke problemen als op de poli?:

\begin{tabular}{l}
$\begin{array}{l}\text { volledig mee eens noch eens/ noch oneens } \\
\text { mee eens } \\
\text { oneens }\end{array}$ \\
\hline
\end{tabular}

\begin{tabular}{|l|l|l|l|l|}
\hline & & & & \\
\hline
\end{tabular}

- Spreekuren uitgevallen?:

0 ja $\rightarrow$ hoe vaak:....keer

$\rightarrow$ reden uitval:

0 nee 
WELKE DOELEN

Wat het meest belangrijk bij Gezamenlijk Consult?:

-kennistoename huisarts:

\begin{tabular}{l}
$\begin{array}{l}\text { volledlg mee cens } \\
\text { mee eens }\end{array}$ \\
\hline
\end{tabular}

-betere interpretatie van de gegevens:

\begin{tabular}{l}
$\begin{array}{l}\text { volledig mee ens } \\
\text { mee eens }\end{array}$ \\
\hline
\end{tabular}

-huisarts kan beter gerichte diagnostiek aanvragen:

\begin{tabular}{l}
$\begin{array}{l}\text { volledig mee eens } \\
\text { mee eens }\end{array}$ \\
\hline
\end{tabular}

-onderzoeksvaardigheden verbeteren:

\begin{tabular}{l}
$\begin{array}{l}\text { volledig meo oens } \\
\text { meo oens }\end{array}$ \\
\hline
\end{tabular}

-therapeutische behandeling verbeteren:

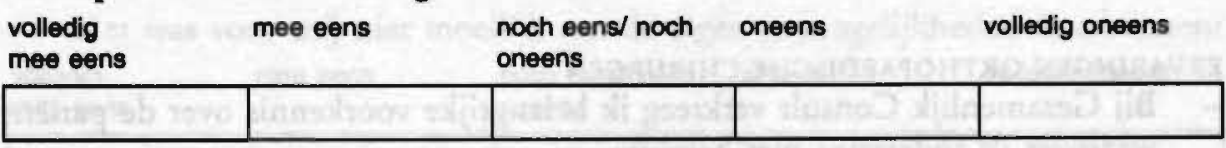

-instelling van second opinion:

$\begin{aligned} & \text { volledig mee oens } \\
& \text { meo } \theta e n s\end{aligned}$
\begin{tabular}{|l|l|l|l|l|}
\hline & \multicolumn{1}{l}{$\begin{array}{l}\text { noch eens/ noch oneens } \\
\text { oneens }\end{array}$} & & \\
\hline & & & & \\
\hline
\end{tabular}


-betere geruststelling van patiënt:

\begin{tabular}{l}
$\begin{array}{l}\text { volledig mee eens } \\
\text { moe oens }\end{array}$ \\
\hline
\end{tabular}

-anders:

\begin{tabular}{|l|l|}
\hline Rapportclifer van $1 \mathrm{Vm} 7$ & Cijfer \\
\hline \hline Kennistoename huisarts & \\
\hline Betere interpretatie van de gegevens & \\
\hline Huisarts kan beter gerichte diagnostiek aanvragen & \\
\hline Onderzoeksvaardigheden verbeteren & \\
\hline Therapeutische behandeling verbeteren & \\
\hline Instelling van second opinion & \\
\hline Betere geruststelling van patiënt & \\
\hline
\end{tabular}

\section{ERVARINGEN ORTHOPAEDISCHE CHIRURGEN}

- Bij Gezamenlijk Consult verkreeg ik belangrijke voorkennis over de patiënt waarover ik anderszins niet beschik:

\begin{tabular}{|c|c|c|c|c|}
\hline $\begin{array}{l}\text { volledig } \\
\text { mee eens }\end{array}$ & mee eens & $\begin{array}{l}\text { noch eens/ noch } \\
\text { oneens }\end{array}$ & oneens & volledig oneens \\
\hline 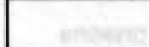 & $x_{1}^{2}$ & 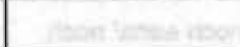 & $2000 \times a n$ & \\
\hline
\end{tabular}


- De patiënt gedraagt zich bij het Gezamenlijk Consult "opener", "mededeelzamer" dan op de poli:

\begin{tabular}{|l|l|l|l|l|}
\hline & & & & \\
\hline
\end{tabular}

- Tijdens het Gezamenlijk Consult werd mijn beleid minder sterk gestuurd door defensieve motieven:

\begin{tabular}{l|l|l|l|l|}
$\begin{array}{l}\text { volledig mee eens } \\
\text { mee eens }\end{array}$ & \multicolumn{1}{l}{$\begin{array}{l}\text { noch eens/ noch oneens } \\
\text { oneens }\end{array}$} & & \\
\hline & & & & \\
\hline
\end{tabular}

- Het Gezamenlijk Consult verschafte belangrijke informatie bij een verwijzing:

volledig mee eens noch eens/ noch oneens volledig oneens
oneens

- Door de ervaring van het Gezamenlijk Consult zijn mijn ideeën over de huisartsentaak op het gebied van orthopaedie belangrijk veranderd:

volledig mer eens mee eens noch eens/ noch oneens oneens volledig oneens

\begin{tabular}{|l|l|l|l|l|}
\hline & & & & \\
\hline
\end{tabular}

- Het was voor mij niet moeilijk om de eigen onmogelijkheden te erkennen: volledig mee eens

mee eens

oneens

\begin{tabular}{|l|l|l|l|l|}
\hline & & & & \\
\hline
\end{tabular}

- Het Gezamenlijk Consult ervoer ik als een prettige taak:

$\begin{aligned} & \text { volledig mee eens } \\
& \text { mee eens }\end{aligned}$
\begin{tabular}{|l|l|l|l|l|}
\hline & $\begin{array}{l}\text { noch eens/ noch oneens } \\
\text { oneens }\end{array}$ & & \\
\hline
\end{tabular}


- Doorgaans heb ik plezier in lesgeven:

\begin{tabular}{l}
$\begin{array}{l}\text { volledig } \\
\text { mee eens }\end{array}$ \\
\hline
\end{tabular}

- Het aspect "lesgeven", "opleiden" gaf mij veel voldoening bij het Gezamenlijk Consult:

$\begin{aligned} & \text { volledig mee eens } \\
& \text { mee eens }\end{aligned}$
\begin{tabular}{|l|l|l|l|l|}
\hline & \multicolumn{1}{l}{$\begin{array}{l}\text { noch eens/ noch oneens } \\
\text { oneens }\end{array}$} & & \\
\hline & & & & \\
\hline
\end{tabular}

- Eigen opmerkingen: 
Zie paragraaf 2.2 (bladzijde 13) en paragraaf 3.1.1. (bladzijde 25). 
$\widetilde{\tilde{H}}$ Verwijzing orthopaedie en overige specialismen* per 1.000 verzekerden in betreffende leeftijdscategorie, alsmede leeftijdsopbouw, 1989. (Bron Z.Z.L. 1991)

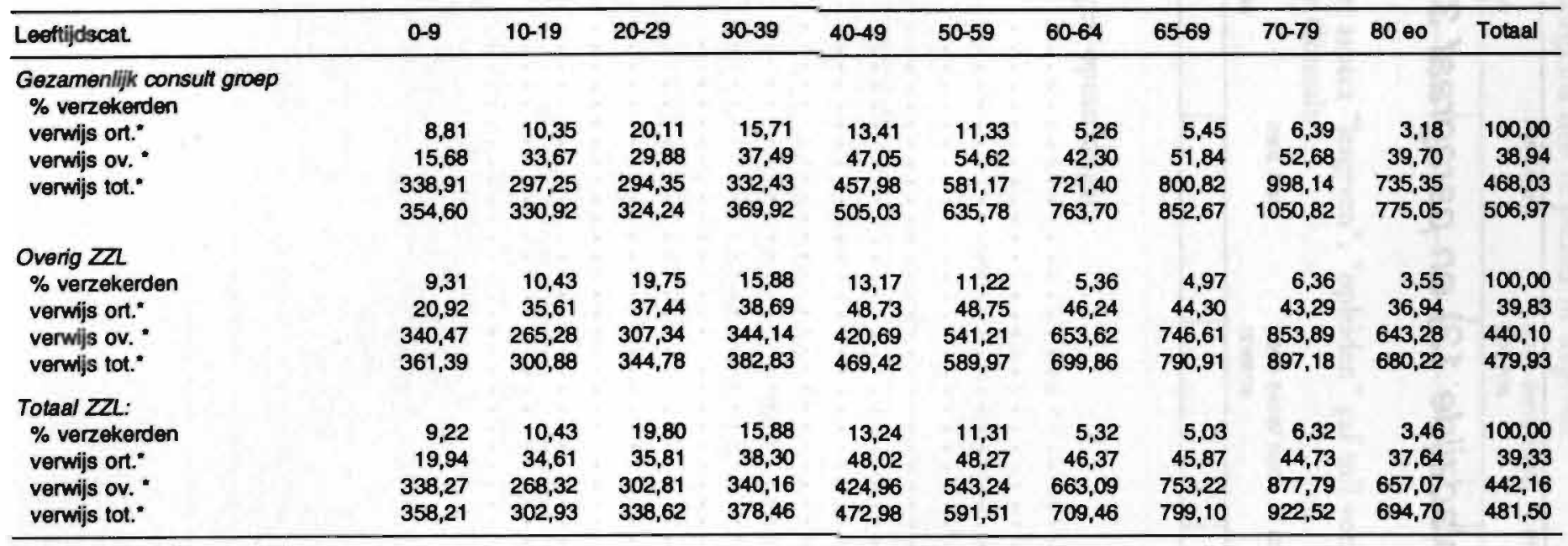


Zie paragraaf 2.5 .4 (bladzijde 18) en paragraaf 3.1.2.1 (bladzijde 29). 
VERKLARING I.C.P.C.-KLACHTENCODERING, HOOFDSTUK L; BEWEGINGSAPPARAAT * ENIGE AANVULLINGEN

01 Nek symptomen, klachten

02 Rug symptomen, klachten

03 Lage rugklachten zonder uitstraling

04 Borstkas symptomen, klachten

05 Flank symptomen, klachten

06 Oksel symptomen, klachten

07 Kaak symptomen, klachten

08 Schouder symptomen, klachten

09 Arm symptomen, klachten

10 Elleboog symptomen, klachten

11 Pols symptomen, klachten

12 Hand en vingers symptomen, klachten

13 Heup symptomen, klachten

14 Been, dijbeen symptomen, klachten

15 Knie symptomen, klachten

16 Enkel symptomen, klachten

17 Voet en teen symptomen, klachten

18 Spierpijn fibrositis

19 Symptomen meerdere/niet gespecificeerde spieren

20 Symptomen meerdere/niet gespecificeerde gewrichten

32 Onderbeen symptonen, klachten

VERKLARING I.C.P.C.-DIAGNOSECODERING

69 Carpale tunnel syndroom, perif. neurol. prikkeling of uitval

70 Infectie ziekten bewegingsapparaat

71 Neoplasmata

72 Fractuur radius ulna

73 Fractuur tibia fibula

74 Fractuur meta-carp, meta-tars, falangen

75 Fractuur femur

76 Andere fracturen

77 Verstuiking en distorsies van de enkel

78 Verstuiking en distorsies van de knie

79 Andere verstuikingen/distorsies incl. slecht gedef.

80 Luxaties en subluxaties

81 Andere traumata bewegingsapparaat

82 Aangeboren afwijkingen bewegingsapparaat

83 Syndromen samenhangend met cervicale wk//andere

84 Arthros. deform. van de wervelkolom wk

85 Verworven misvormingen van de wervelkolom wk

86 Discus degeneratie met uirstraling ex. cerv.

87 Ganglion gewricht of pees

88 Reumatische arthrit/spond.ankylop. verwante aandoeningen 
89 Arthrosis deformans heup

90 Arthrosis derformans knie

91 Arthrosis derformans andere/verw.aandoeningen

92 Schouder syndromen

93 Epicondylitis lateralis

94 Osteochondrosis, Osgood-Schlatter, Scheuermans ea

95 Osteoporosis

96 Acute traumata meniscus en kniebanden

97 Chronisch inwendig trauma van de knie

98 Verworven misvormingen extremiteiten

99 Andere aandoeningen bewegingsapparaat 
Zie paragraaf 3.1.5.1. (bladzijde 56) 
Tabel 3.1.5.1.I Mate van beperking van activiteit vooraf volgens patiënt per groep tijdens instroomconsult: Heeft u vanwege uw klacht uw activiteiten in verband met uw werk moeten beperken in de afgelopen 12 maanden?

\begin{tabular}{lcc}
\hline In werk & $\begin{array}{c}\text { Interventiegroep* } n=144 \\
\%\end{array}$ & $\begin{array}{c}\text { Controlegroep* } n=128 \\
\%\end{array}$ \\
\hline ja & 38,2 & 46,1 \\
nee & 53,5 & 45,3 \\
\hline
\end{tabular}

Chi-kwadraattoets $p=0.21$

Tabel 3.1.5.1.II Mate van beperking van activiteit vooraf volgens patiënt per groep tijdens instroomconsult: Heeft u vanwege uw klacht uw activiteiten in verband met uw vrije tijd moeten beperken in de afgelopen 12 maanden?

\begin{tabular}{lcc}
\hline In vrije tijd & $\begin{array}{c}\text { Interventiegroep" } \\
\%=144\end{array}$ & $\begin{array}{c}\text { Controlegroep" } n=128 \\
\%\end{array}$ \\
\hline la & 72,9 & 68,8 \\
nee & 27,1 & 27,3 \\
\hline
\end{tabular}

Chi-kwadraattoets $p=0.91$

Tabel 3.1.5.1.III Mate van beperking van activiteit vooraf volgens patiënt per groep tijdens instroomconsult: Hoeveel tijd heeft u vanwege de klacht uw dagelijkse werkzaamheden niet kunnen doen de afgelopen 12 maanden?

\begin{tabular}{lcc}
\hline & $\begin{array}{c}\text { Interventiegroep* } n=144 \\
\%\end{array}$ & $\begin{array}{c}\text { Controlegroep* } n=128 \\
\%\end{array}$ \\
\hline 0 dagen & 44,4 & 39,1 \\
1- 7 dagen & 7,6 & 18,0 \\
8-30 dagen & 16,7 & 14,8 \\
meer dan 30 dagen & 20,1 & 20,3 \\
\hline
\end{tabular}

Chi-kwadraattoets $p=0.09$

Tabel 3.1.5.1.IV Mate van beperking van activiteit vooraf volgens patiënt per groep tijdens instroomconsult: $\mathrm{Zijn}$ vanwege uw klacht naar uw mening het aantal sociale contacten afgenomen in de laatste 12 maanden?

\begin{tabular}{lcc}
\hline & $\begin{array}{c}\text { Interventiegroep } \\
\%=144\end{array}$ & $\begin{array}{c}\text { Controlegroep } n=128 \\
\%\end{array}$ \\
\hline ja & 10,4 & 6,3 \\
nee & 88,2 & 90,6 \\
niet ingevuld & 1,4 & 3,1 \\
\hline
\end{tabular}

- Chi-kwadraattoets $p=0.33$ (geloetst zonder item 'niet ingevuld'). 
De instroomgegevens ten aanzien van werk en activiteiten gaven gerelateerd aan de verwijsgegevens eveneens geen opvallende resultaten te zien (geen tabellen opgenomen).

Tabel 3.1.5.1.V Mate van beperking van activiteiten gedurende het onderzoeksjaar volgens patiënt per groep: Heeft u vanwege de klacht uw activiteiten moeten beperken in de afgelopen 12 maanden?

Interventiegroep $n=144$ Controlegroep $n=128$

$\%$

$\%$

\begin{tabular}{lrr}
\hline In werk" & & 10,2 \\
ja, geheel & 6,9 & 51,6 \\
ja, gedeeltelijk & 39,6 & 38,3 \\
nee & 53,5 & 7,8 \\
In vrlje tijd"* & 8,3 & 58,3 \\
ja, geheel & 54,2 & 48,8 \\
ja, gedeeltelijk & 37,5 & \\
nee & & \\
\hline$\quad$ Chi-kwadraattoets p=0.42 & & \\
\hline Chi-kwadraattoets p=0.68 & &
\end{tabular}

Tabel 3.1.5.1.VI Mate van werkverzuim gedurende het onderzoeksjaar volgens patiënt per groep: Hoeveel tijd heeft u vanwege uw klacht uw dagelijkse werkzaamheden niet kunnen doen de afgelopen 12 maanden?

\begin{tabular}{lcr}
\hline & $\begin{array}{c}\text { Interventiegroep } n=144 \\
\%\end{array}$ & $\begin{array}{c}\text { Controlegroep } \\
\%=128\end{array}$ \\
\hline 0 weken & 27,3 & 21,9 \\
1 week & 1,3 & 2,8 \\
$2-4$ weken & 5,8 & 6,3 \\
$1-3$ maanden & 14,3 & 22,5 \\
4 maanden & 1,9 & 2,1 \\
5 maanden & 3,9 & 4,2 \\
6 maanden & 3,2 & 4,9 \\
7 maanden & 3,2 & 0,7 \\
8 maanden & 1,9 & 2,8 \\
9 maanden & 1,3 & 0,0 \\
10 maanden & 0,6 & 1,4 \\
11 maanden & 0,0 & 0,7 \\
12 maanden & 25,3 & 19,7 \\
\hline
\end{tabular}

Chi-kwadraattoets $p=0.37$

(getoetst met de items '1 week' en '2-4 weken' samengevoegd; evenals de items ' 4 ', ' 5 ' en ' 6 maanden'; en de items ' 7 ', ' 8 ' en ' 9 maanden'; en de items '10'. '11' en '12 maanden' samengovoegd: off=4). 
Tabel 3.1.5.1.VII Mate van werkverzuim gedurende het onderzoeksjaar volgens patiënt per groep: Is naar uw mening het aantal sociale contacten afgenomen de afgelopen 12 maanden?

\begin{tabular}{lcc}
\hline & Interventiegroep* $n=144$ & Controlegroep* $n=128$ \\
\hline la & $\%$ & 14,1 \\
nee & 9,0 & 58,6 \\
niet van toepassing & 59,8 & 27,3 \\
\hline
\end{tabular}


Zie paragraaf 6.2. (bladzijde 110) 
Geachte collega,

Door middel van deze brief willen wij uw medewerking vragen voor en informatie verstrekken over het onderzoeksprojekt "Gezamenlijk Consult in de huisartspraktijk voor klachten van het bewegingsapparaat". Dit project valt onder het beheer van het Diagnostisch Centrum en de vakgroep Huisartsgeneeskunde van de R.L. en is in januari 1989 in een twaalftal huisartspraktijken van start gegaan. Hierbij ter verduidelijking enige informatie over het "Gezamenlijk Consult".

Verwijzen is niet altijd een zwart/wit beslissing. ledere huisarts weet dat hierbij een groot grijs gebied bestaat waarin diverse factoren meespelen die uiteindelijk resulteren in de beslissing: al of niet verwijzen. In het "Gezamenlijk Consult" houden groepjes van drie huisartsen samen met een orthopedische chirurg van het $A Z M$, in de spreekkamer van de huisarts, om de twee weken een spreekuur voor patiënten met klachten van het bewegingsapparaat.

De patiënten die voor dit gezamenlijk consult in aanmerking komen moeten voldoen aan een aantal criteria.

Het zijn patiënten met doorgaans langer bestaande klachten uit het bovengenoemde grijze gebied, waarbij de huisarts een gezamenlijk onderzoek en overleg met de orthopaed van belang vindt.

Naast het effekt van nascholing heeft het "Gezamenlijk Consult" tot doel onnodige verwijzingen en onderzoek te voorkomen.

De vraag is of deze voorziening voor grotere groepen huisartsen van belang kan zijn. Wij willen een antwoord krijgen op deze vraag door bij $U$ als huisartsen na te gaan wanneer een gezamenlijk consult naar uw mening zinvol is. Wij stellen deze vraag bij een steekproefgewijs samengestelde groep van nieuw verwezen patiënten naar de polikliniek orthopedie.

Het hoofddoel van dit onderzoek is te komen tot een juiste plaarsbepaling van de voorziening "Gezamenlijk Consult" in de huisartsprakrijk. Dit kan alleen gebeuren als een voldoende aantal huisartsen ons hierbij helpt. Daarom verzoeken wij ook $U$ aan dit onderzoek mee te werken.

We zullen u zo min mogelijk belasten. Wanneer u wilt meedoen aan onze behoefte-peiling kunt u hoogstens enkele malen gevraagd worden een korte vragenlijst (zie bijlage) in te vullen over een recent verwezen patiënt. De vragen betreffen uw beweegredenen voor de verwijzing en uw mening over de eventuele wenselijkheid en motieven voor een gezamenlijk consult bij deze patiënt.

De gegevens worden vanzelfsprekend vertrouwelijk en als medisch geheim behandeld. 
Om over uw bereidheid tot deelname geïnformeerd te worden, vragen wij $U$ bijgaand deelnameformulier naar ons op te sturen.

Bij voorbaat onze dank voor uw medewerking.

Met collegiale groeten,

W. Vierhout, huisarts, telefoon: $043-430850$

B. Schilte, arts onderzoeker

A. Knottnerus, voorzitter van de vakgroep huisartsgeneeskunde

A. van Ooij, orthopaedisch chirurg AZM

P. Pop, internist Diagnostisch Centrum 
Deelnameformulier, gezamenlijk consult in de huisartspraktijk

Vanwege de behoefte peiling van het gezamenlijk consult in de huisartspraktijk stem ik er wel/niet in toe enige vragenformulieren in te zenden betreffende enkele nieuw - verwezen orthopaedie patiënten.

Naam:

(gaarne stempel). 
Zie paragraaf 6.2. (bladzijde 110) 
Naam patiënt: $\ldots \ldots \ldots \ldots \ldots$ Naam huisarts: . . . . . . . . .

Geboortedatum:

datum poli afspraak:

1. Hoe lang heeft deze patiënt de klacht?
0 korter dan 1 maand
0 langer dan 1 maand maar korter dan 6 maanden
0 langer dan 6 maanden maar korter dan 1 jaar
0 langer dan 1 jaar

2. Hoeveel last of hinder had deze patiënt van de klacht?
0 zeer veel
0 veel
0 matig
0 weinig
0 geen

3. Denkt u dat de patiënt zich zorgen maakte over deze klacht?
0 zeer veel
0 veel
0 marig
0 weinig
0 geen

4. Verzocht de patiënt zelf om een verwijzing?
0 ja
0 nee
0 anders n.l.
0 weet niet

5. Ik verwees deze patiënt om de volgende reden(en). (Eventueel meerdere hokjes aan te kruisen).

0 Ik had geen duidelijke diagnose

0 Ik wilde een second opinion

0 Ik verwachtte ernstige pathologie

0 Er was een acuut (ernstig) probleem

0 Ik had geen therapeutisch plan waar ik succes van verwachtte

0 Het plan was niet uitvoerbaar door de huisarts

0 Bij dit probleem kan de orthopedische chirurg de meest adequate behandeling geven

0 Anders n.l. 
6. Gesteld dat u de mogelijkheid had van een gezamenlijk consult gebruik te maken, zou u dan deze patiënt hierin in aanmerking hebben laten komen.

0 ja

0 nee

0 anders

0 weet niet 
Resultaten van de multipele logistische regressie voor de afhankelijke variabele "klachtenvrij zijn van de patiënt na één jaar, naar het oordeel van de orthopaed'.

\begin{tabular}{|c|c|c|c|c|c|}
\hline \multirow{3}{*}{$\begin{array}{l}\text { Variabele } \\
\text { groep }(1=\text { interventie } \\
0=\text { controle) }\end{array}$} & \multicolumn{3}{|c|}{ Full Model } & \multicolumn{2}{|c|}{ Reduced Model } \\
\hline & \multirow{2}{*}{$\frac{\mathrm{OR}}{1.87}$} & \multicolumn{2}{|c|}{$95 \% \mathrm{Cl}$} & \multirow{2}{*}{$\frac{\text { OR }}{1.82}$} & $95 \% \mathrm{Cl}$ \\
\hline & & 1.04 & 3.36 & & 1.04 \\
\hline duur ( 1 =lang, $0=$ kort) & 0.467 & 0.251 & 0.869 & 0.500 & $0.288 \quad 0.867$ \\
\hline $\begin{array}{l}\text { last/hinder (1=veel, } \\
0=\text { weinig) }\end{array}$ & 1.23 & 0.624 & 2.43 & & 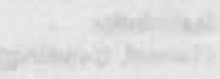 \\
\hline ernst ( 1 =veel, $0=$ weinig) & 0.987 & 0.526 & 1.85 & 64 & 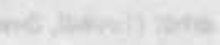 \\
\hline $\begin{array}{l}\text { gerustgesteld } \\
(1=j a, 0=\text { nee })\end{array}$ & 0.851 & 0.453 & 1.60 & & 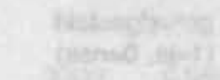 \\
\hline $\begin{array}{l}\text { wens venwijzing } \\
(1=j a, 0=n \theta \theta)\end{array}$ & 1.16 & 0.635 & 2.10 & & 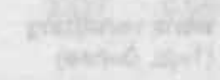 \\
\hline $\begin{array}{l}\text { eerder identieke klachten } \\
(1=\mathrm{ja}, 0=n \theta e)\end{array}$ & 0.575 & 0.294 & 1.12 & Anen 0 ati & 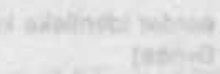 \\
\hline $\begin{array}{l}\text { psychosociale aspecten ( } 1=j a, \\
0=n \theta \theta)\end{array}$ & 0.348 & 0.137 & 0.885 & 0.369 & $0.155 \quad 0.879$ \\
\hline $\begin{array}{l}\text { onzekere diagnose } \\
(1=\mathrm{ja}, 0=\text { nee })\end{array}$ & 0.750 & 0.381 & 1.48 & & 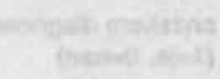 \\
\hline $\begin{array}{l}\text { second opinion } \\
(1=j \mathrm{a}, 0=\text { ne日) }\end{array}$ & 1.69 & 0.890 & 3.22 & & 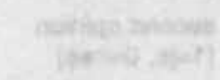 \\
\hline $\begin{array}{l}\text { kennisvermeerdering } \\
(1=\mathrm{ja}, 0=\text { ne日) }\end{array}$ & 1.21 & 0.664 & 2.19 & & 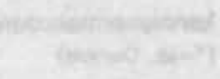 \\
\hline $\begin{array}{l}\text { vaardigheden ontwikkelen } \\
(1=\mathrm{j} a, 0=n \Theta \theta)\end{array}$ & 1.71 & 0.876 & 3.34 & 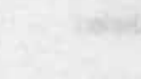 & 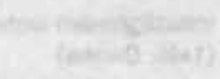 \\
\hline $\begin{array}{l}\text { overbodige verwijzing voor- } \\
\text { komen }(1=\mathrm{ja}, 0=\text { nee })\end{array}$ & 0.946 & 0.520 & 1.72 & $\sin$ & 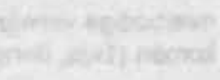 \\
\hline overleg $(1=j a, 0=n e \theta)$ & 1.65 & 0.612 & 4.46 & & 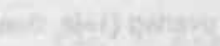 \\
\hline $\begin{array}{l}\text { patiënt ongerust } \\
(1=j a, 0=n \theta \theta)\end{array}$ & 1.89 & 0.782 & 4.58 & & wetcing \\
\hline $\begin{array}{l}\text { patiênt vroeg om verwijzing } \\
(1-j a, 0=\text { nee })\end{array}$ & 0.355 & $0.885 E-01$ & 1.42 & $x^{2}+x_{1}=$ & 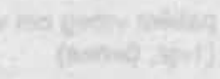 \\
\hline $\begin{array}{l}\text { som. fixatie voorkomen } \\
(1=\mathrm{j}, 0=\text { nee })\end{array}$ & 1.32 & 0.291 & 5.98 & & 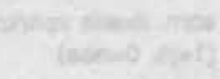 \\
\hline $\begin{array}{l}\text { life-events } \\
(1=\mathrm{a}, 0=\text { neө })\end{array}$ & 1.03 & 0.513 & 2.09 & & 40 \\
\hline constante & -1.049 & SE: 0 & & -0.6807 & SE: 0.253 \\
\hline log likelihood & -143.333 & & & -151.506 & - \\
\hline
\end{tabular}




\section{Resultaten van de multipele logistische regressie voor de afhankelijke variabele 'medicatie op voorschrift van de huisarts'}

\begin{tabular}{|c|c|c|c|c|c|c|}
\hline \multicolumn{2}{|l|}{ 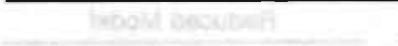 } & \multicolumn{3}{|c|}{ Full Model } & \multicolumn{2}{|r|}{ Reduced Model } \\
\hline \multirow{2}{*}{$\begin{array}{l}\text { Variabele } \\
\text { groep (1=interventie } \\
0=\text { controle) }\end{array}$} & \multirow{2}{*}{20} & \multirow{2}{*}{$\frac{\mathrm{OR}}{1.18}$} & \multicolumn{2}{|c|}{$95 \% \mathrm{Cl}$} & \multirow[t]{2}{*}{ OR } & \multirow{2}{*}{$95 \% \mathrm{Cl}$} \\
\hline & & & 0.536 & 2.59 & & \\
\hline \multicolumn{2}{|c|}{ duur ( $1=$ lang, $0=$ kort $)$} & 1.42 & 0.608 & 3.33 & \multicolumn{2}{|r|}{ 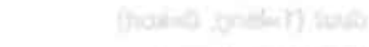 } \\
\hline \multicolumn{2}{|l|}{$\begin{array}{l}\text { las/hinder } \\
(1=\text { veel, } 0=\text { =weinig })\end{array}$} & 1.07 & 0.411 & 2.79 & \multicolumn{2}{|r|}{ 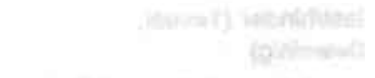 } \\
\hline \multicolumn{2}{|l|}{ emst ( 1 =veel, $0=$ weinig) } & 4.60 & 1.95 & 10.8 & \multicolumn{2}{|c|}{$\begin{array}{lll}3.59 & 1.73 & 7.46\end{array}$} \\
\hline \multicolumn{2}{|l|}{$\begin{array}{l}\text { gerustgesteld } \\
(1=j a, 0=\text { nee })\end{array}$} & 0.485 & 0.191 & 1.23 & \multicolumn{2}{|r|}{ 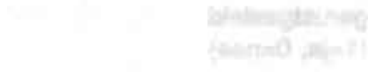 } \\
\hline \multicolumn{2}{|l|}{$\begin{array}{l}\text { wens verwijzing } \\
\text { (1=ja, } 0=\text { nee })\end{array}$} & 0.523 & 0.229 & 1.19 & \multicolumn{2}{|r|}{ 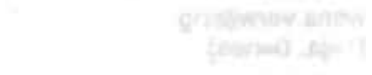 } \\
\hline \multicolumn{2}{|c|}{$\begin{array}{l}\text { eerder identieke klachten }(1=j a \text {, } \\
0=n \theta \theta)\end{array}$} & 1.04 & 0.454 & 2.37 & \multicolumn{2}{|c|}{ 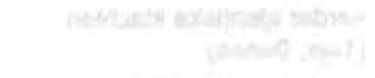 } \\
\hline \multicolumn{2}{|c|}{$\begin{array}{l}\text { psychosoclale aspecten ( } 1=j \mathrm{a}, \\
0=\text { nee) }\end{array}$} & 2.13 & 0.824 & 5.51 & \multicolumn{2}{|c|}{ 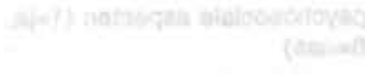 } \\
\hline \multicolumn{2}{|l|}{$\begin{array}{l}\text { onzekere diagnose } \\
\text { (1=ja, } 0=\text { nee) }\end{array}$} & 1.48 & 0.610 & 3.57 & \multicolumn{2}{|r|}{ 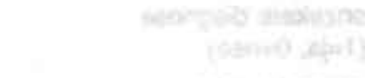 } \\
\hline \multicolumn{2}{|l|}{ 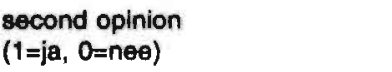 } & 0.942 & 0.407 & 2.18 & \multicolumn{2}{|r|}{ 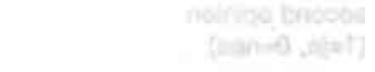 } \\
\hline \multicolumn{2}{|l|}{$\begin{array}{l}\text { kennisvermeerdering } \\
(i=j a, 0=n \theta \theta)\end{array}$} & 2.07 & 0.887 & 4.85 & \multicolumn{2}{|c|}{$\begin{array}{lll}2.26 & 1.09 & 4.69\end{array}$} \\
\hline \multicolumn{2}{|c|}{$\begin{array}{l}\text { vaardigheden ontwikkelen } \\
\text { (1=ja, } 0=n \theta e)\end{array}$} & 1.03 & 0.429 & 2.45 & \multicolumn{2}{|c|}{ 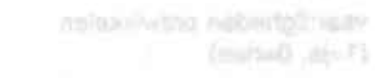 } \\
\hline \multicolumn{2}{|c|}{$\begin{array}{l}\text { overbodige verwijzing voor- } \\
\text { komen }(1=j a, 0=n e \theta)\end{array}$} & 1.36 & 0.610 & 3.05 & \multicolumn{2}{|c|}{ 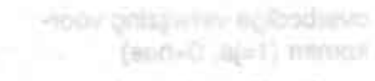 } \\
\hline \multicolumn{2}{|l|}{ overleg $(1=\mathrm{ja}, 0=$ nee $)$} & 1.54 & 0.473 & 5.04 & \multicolumn{2}{|r|}{ 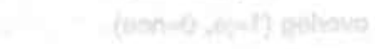 } \\
\hline $\begin{array}{l}\text { patiēnt ongenust } \\
(1=j \mathrm{a}, 0=\mathrm{n} \theta \theta)\end{array}$ & & 0.649 & 0.183 & 2.31 & & 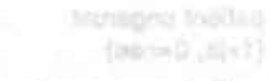 \\
\hline $\begin{array}{l}\text { patiênt vroeg om verm } \\
(1=j a, 0=n \theta \theta)\end{array}$ & wijzing & $0.247 E-03$ & $0.121 E-19$ & $0.505 E+13$ & $\operatorname{esc}\left(a_{1}=\right.$ & 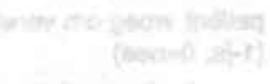 \\
\hline $\begin{array}{l}\text { som. fixatie voorkome } \\
(1=\mathrm{j} a, 0=\text { nee })\end{array}$ & & 0.268 & $0.268 E-01$ & 2.69 & & 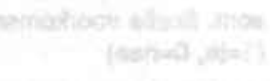 \\
\hline 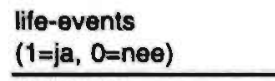 & & 0.974 & 0.390 & 2.43 & & 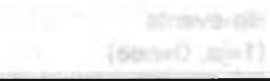 \\
\hline constante & 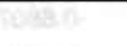 & -3.078 & SE: $C$ & .724 & -2.864 & SE: 0.384 \\
\hline log likelihood & $2=1=5$ & -89.477 & & 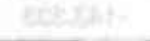 & -103.73 & 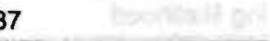 \\
\hline
\end{tabular}




\section{Resultaten van de multipele logistische regressie voor de afhankelijke variabele verwijzing fysiotherapie op voorschrift van de huisarts'}

\begin{tabular}{|c|c|c|c|c|c|c|}
\hline \multicolumn{2}{|l|}{ 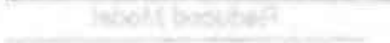 } & \multicolumn{3}{|c|}{ Full Model } & \multicolumn{2}{|c|}{ Reduced Model } \\
\hline \multirow{2}{*}{$\begin{array}{l}\text { Variabele } \\
\text { groep (1=interventie } \\
0=\text { controle) }\end{array}$} & \multirow{2}{*}{ 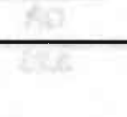 } & \multirow{2}{*}{$\frac{\text { OR }}{1.11}$} & \multicolumn{2}{|c|}{$95 \% \mathrm{Cl}$} & \multirow[t]{2}{*}{ OR } & \multirow{2}{*}{$95 \% \mathrm{Cl}$} \\
\hline & & & 0.620 & 1.97 & & \\
\hline \multicolumn{2}{|l|}{ duur ( 1 =lang, $0=$ kort) } & 0.742 & 0.400 & 1.38 & & 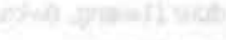 \\
\hline \multicolumn{2}{|l|}{$\begin{array}{l}\text { last/hinder } \\
\text { ( } 1=\text { veel, } 0=\text { weinig) }\end{array}$} & 0.140 & 0.698 & 2.82 & & 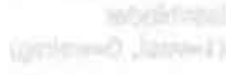 \\
\hline \multicolumn{2}{|l|}{ ernst $(1=$ veel, $0=$ weinig $)$} & 1.15 & 0.616 & 2.15 & tat & 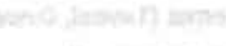 \\
\hline \multicolumn{2}{|l|}{$\begin{array}{l}\text { gerustgesteld } \\
(1=\mathrm{ja}, 0=\text { nee })\end{array}$} & 1.04 & 0.553 & 1.94 & & 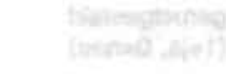 \\
\hline \multicolumn{2}{|l|}{$\begin{array}{l}\text { wens verwijzing } \\
(1=\mathrm{je}, 0=\text { nee })\end{array}$} & 0.576 & 0.315 & 1.05 & 0.550 & $0.317 \quad 0.953$ \\
\hline \multicolumn{2}{|c|}{$\begin{array}{l}\text { eerder identieke klachten ( } 1=j a \text {, } \\
0=\text { nee) }\end{array}$} & 1.74 & 0.923 & 3.27 & 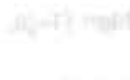 & 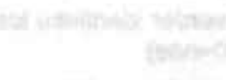 \\
\hline \multicolumn{2}{|c|}{$\begin{array}{l}\text { psychosociale aspecten ( } 1=\mathrm{ja}, \\
0=\mathrm{n} \theta \theta)\end{array}$} & 1.98 & 0.954 & 4.13 & 2.06 & $1.07 \quad 3.98$ \\
\hline \multicolumn{2}{|l|}{$\begin{array}{l}\text { onzekere diagnose } \\
(1=\mathrm{ja}, 0=\text { nee })\end{array}$} & 0.671 & 0.330 & 1.36 & & 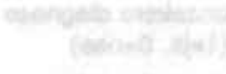 \\
\hline \multicolumn{2}{|l|}{$\begin{array}{l}\text { second opinion } \\
\text { (1=ja, } 0=\text { nee })\end{array}$} & 1.66 & 0.885 & 3.13 & & 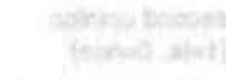 \\
\hline \multicolumn{2}{|l|}{$\begin{array}{l}\text { kennisvermeerdering } \\
(1=\mathrm{ja}, 0=\text { neө })\end{array}$} & 0.764 & 0.419 & 1.39 & & 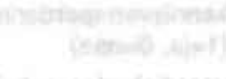 \\
\hline \multicolumn{2}{|c|}{$\begin{array}{l}\text { vaardigheden ontwikkelen } \\
\text { (1=ja, } 0=n e \theta)\end{array}$} & 0.872 & 0.444 & 1.71 & pats & 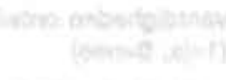 \\
\hline \multicolumn{2}{|c|}{$\begin{array}{l}\text { overbodige verwijzing } \\
\text { voorkomen }(1=\mathrm{ja}, 0=\text { nee })\end{array}$} & 0.627 & 0.344 & 1.14 & & 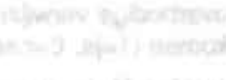 \\
\hline \multicolumn{2}{|l|}{ overleg $(1=\mathrm{ja}, 0=$ nee $)$} & 0.277 & $0.818 E-01$ & 0.937 & & 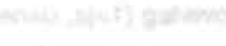 \\
\hline \multicolumn{2}{|l|}{$\begin{array}{l}\text { patiënt ongerust } \\
(1=\mathrm{ja}, 0=\text { nөe })\end{array}$} & 3.23 & 1.35 & 7.73 & 2.99 & $1.40 \quad 6.36$ \\
\hline \multicolumn{2}{|c|}{$\begin{array}{l}\text { patiênt vroeg om verwijzing } \\
(1=j a, 0=n \theta \theta)\end{array}$} & 0.367 & 0.111 & 1.21 & 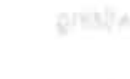 & 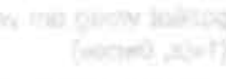 \\
\hline \multicolumn{2}{|l|}{$\begin{array}{l}\text { som. fixatie voorkomen } \\
(1=j a, 0=\text { nee })\end{array}$} & 2.35 & 0.615 & 8.97 & & 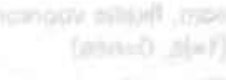 \\
\hline \multicolumn{2}{|l|}{$\begin{array}{l}\text { life-events } \\
(1=j a, 0=\text { nee })\end{array}$} & 1.20 & 0.604 & 2.39 & & $10+20+2$ \\
\hline constante & $x+2$ & -0.8540 & SE: 0 & & -0.8169 & SE: 0.200 \\
\hline log likelihood & $25 a^{2}=$ & -144.621 & & & -156.870 & 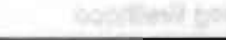 \\
\hline
\end{tabular}




\section{Resultaten van de multipele logistische regressie voor de afhankelijke variabele injecties gegeven door de huisarts'}

\begin{tabular}{|c|c|c|c|c|c|}
\hline \multirow{3}{*}{$\begin{array}{l}\text { Variabele } \\
\text { groep (1=interventie } \\
0=\text { controle) }\end{array}$} & \multicolumn{3}{|c|}{ Full Model } & \multicolumn{2}{|c|}{ Reduced Model } \\
\hline & \multirow{2}{*}{$\frac{O R}{3.22}$} & \multicolumn{2}{|c|}{$95 \% \mathrm{Cl}$} & \multirow{2}{*}{$\begin{array}{c}\text { OR } \\
3.23\end{array}$} & $95 \% \mathrm{Cl}$ \\
\hline & & 0.137 & 7.58 & & $\begin{array}{ll}1.44 & 7.23\end{array}$ \\
\hline duur ( 1 =lang, $0=$ kort ) & 0.886 & 0.389 & 2.02 & & 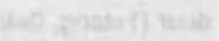 \\
\hline $\begin{array}{l}\text { last/hinder } \\
\text { (1=veel, } 0=\text { weinig) }\end{array}$ & 2.12 & 0.742 & 6.06 & & 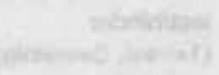 \\
\hline emst ( 1 =veel, $0=$ weinig) & 1.10 & 0.475 & 2.56 & & 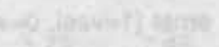 \\
\hline $\begin{array}{l}\text { gerustgesteld } \\
(1=\mathrm{a}, 0=\text { nee })\end{array}$ & 1.19 & 0.515 & 2.77 & & 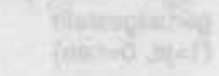 \\
\hline $\begin{array}{l}\text { wens verwijzing } \\
\text { (1=ja, } 0=\text { neө) }\end{array}$ & 1.26 & 0.567 & 2.81 & & 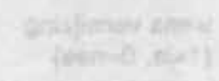 \\
\hline $\begin{array}{l}\text { eerder identieke klachten ( } 1=j a \text {, } \\
0=\text { nee })\end{array}$ & 1.61 & 0.703 & 3.70 & 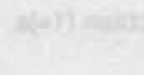 & 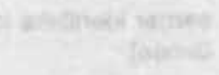 \\
\hline $\begin{array}{l}\text { psycho-sociale aspecten ( } 1=j a, \\
0=\text { nee) }\end{array}$ & 1.42 & 0.517 & 3.90 & $x=$ & 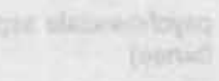 \\
\hline $\begin{array}{l}\text { onzekere diagnose } \\
(1=\mathrm{ja}, 0=\text { nee })\end{array}$ & 0.588 & 0.203 & 1.71 & & 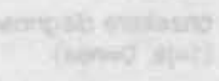 \\
\hline $\begin{array}{l}\text { second opinion } \\
(1=\mid \mathrm{a}, 0=\text { ne日) }\end{array}$ & 0.694 & 0.282 & 1.71 & & 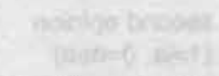 \\
\hline $\begin{array}{l}\text { kennisvermeerdering } \\
(1=\mathbf{a}, 0=n \theta \theta)\end{array}$ & 0.333 & 0.141 & 0.785 & 0.295 & $0.132 \quad 0.659$ \\
\hline $\begin{array}{l}\text { varadigheden ontwikkelen } \\
(1=j a, 0=n \theta \theta)\end{array}$ & 3.65 & 1.53 & 8.74 & 4.28 & $1.96 \quad 9.35$ \\
\hline $\begin{array}{l}\text { overbodige verwijzing voor- } \\
\text { komen }(1=\mathrm{ja}, 0=n e \theta)\end{array}$ & 0.911 & 0.407 & 2.04 & $x_{0}=$ & 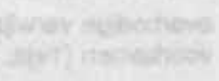 \\
\hline overleg $(1=j a, 0=n e \theta)$ & 0.319 & $0.376 E-01$ & 2.70 & & 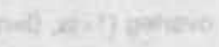 \\
\hline $\begin{array}{l}\text { patient ongerust } \\
(1=j \mathrm{a}, 0=\text { ne } \theta)\end{array}$ & 1.48 & 0.469 & 4.67 & & 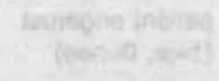 \\
\hline $\begin{array}{l}\text { patiênt vroeg om verwijzing } \\
(1=j a, 0=n e \theta)\end{array}$ & 0.449 & $0.960 \mathrm{E}-01$ & 2.10 & $30 x+10 x$ & 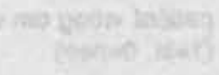 \\
\hline $\begin{array}{l}\text { som. fixatie voorkomen } \\
(1=\mathrm{ja}, 0=\text { nee })\end{array}$ & 0.741 & 0.128 & 4.30 & & 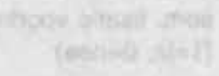 \\
\hline $\begin{array}{l}\text { life-events } \\
(1=j a, 0=n \theta \theta)\end{array}$ & 0.482 & 0.162 & 1.43 & & 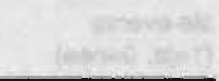 \\
\hline Constante & -2.965 & SE: 0 & & -2.498 & SE: 0.389 \\
\hline log likelihood & -89.337 & & & -95.709 & 6 \\
\hline
\end{tabular}




\section{Resultaten van de multipele logistische regressie voor de afhankelijke variabele 'röntgenonderzoek op aanvraag van de huisarts'}

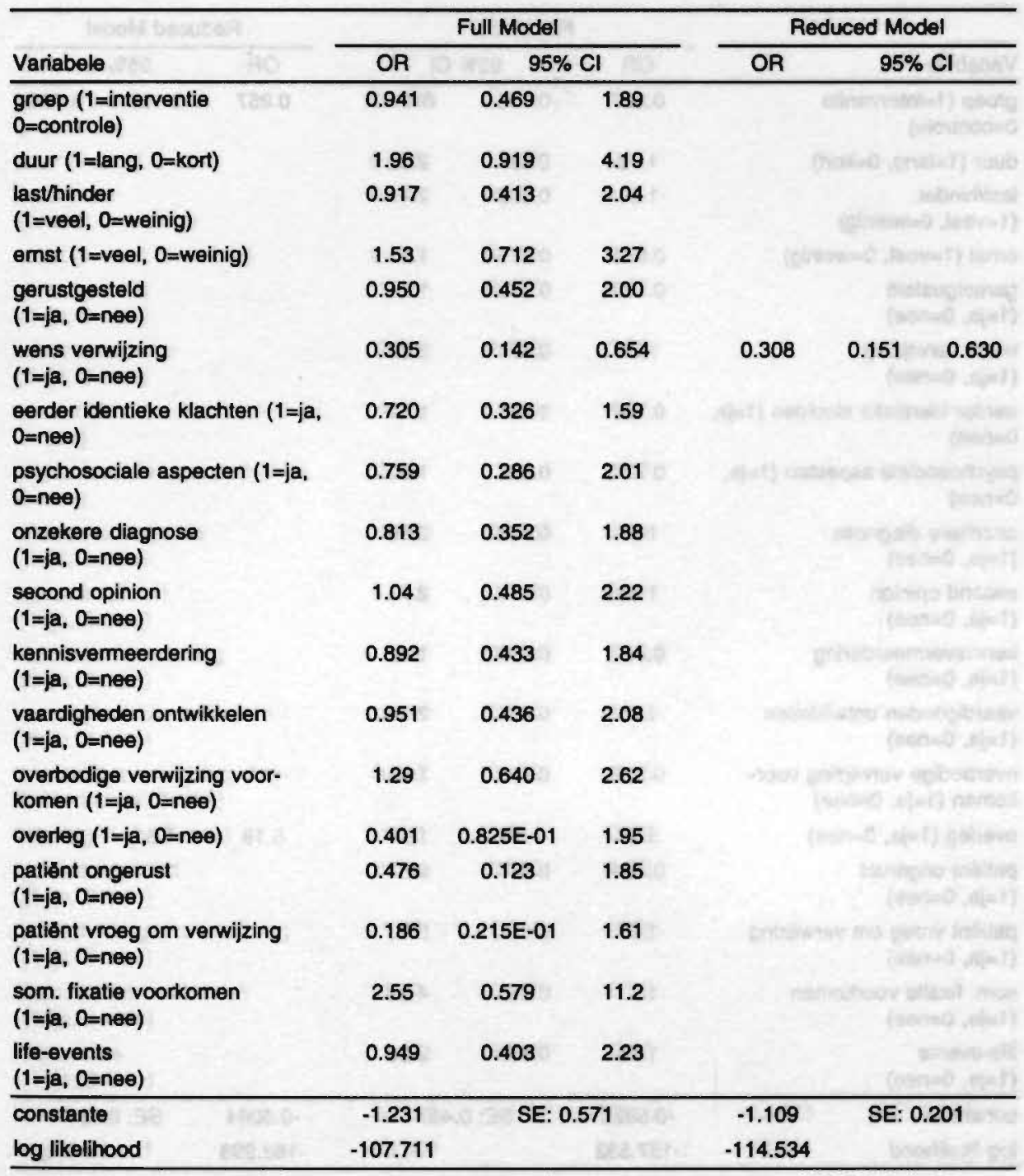




\section{Resultaten van de multipele logistische regressie voor de afhankelijke variabele 'wel en niet verwezen patiënten naar de polikliniek orthopaedie'}

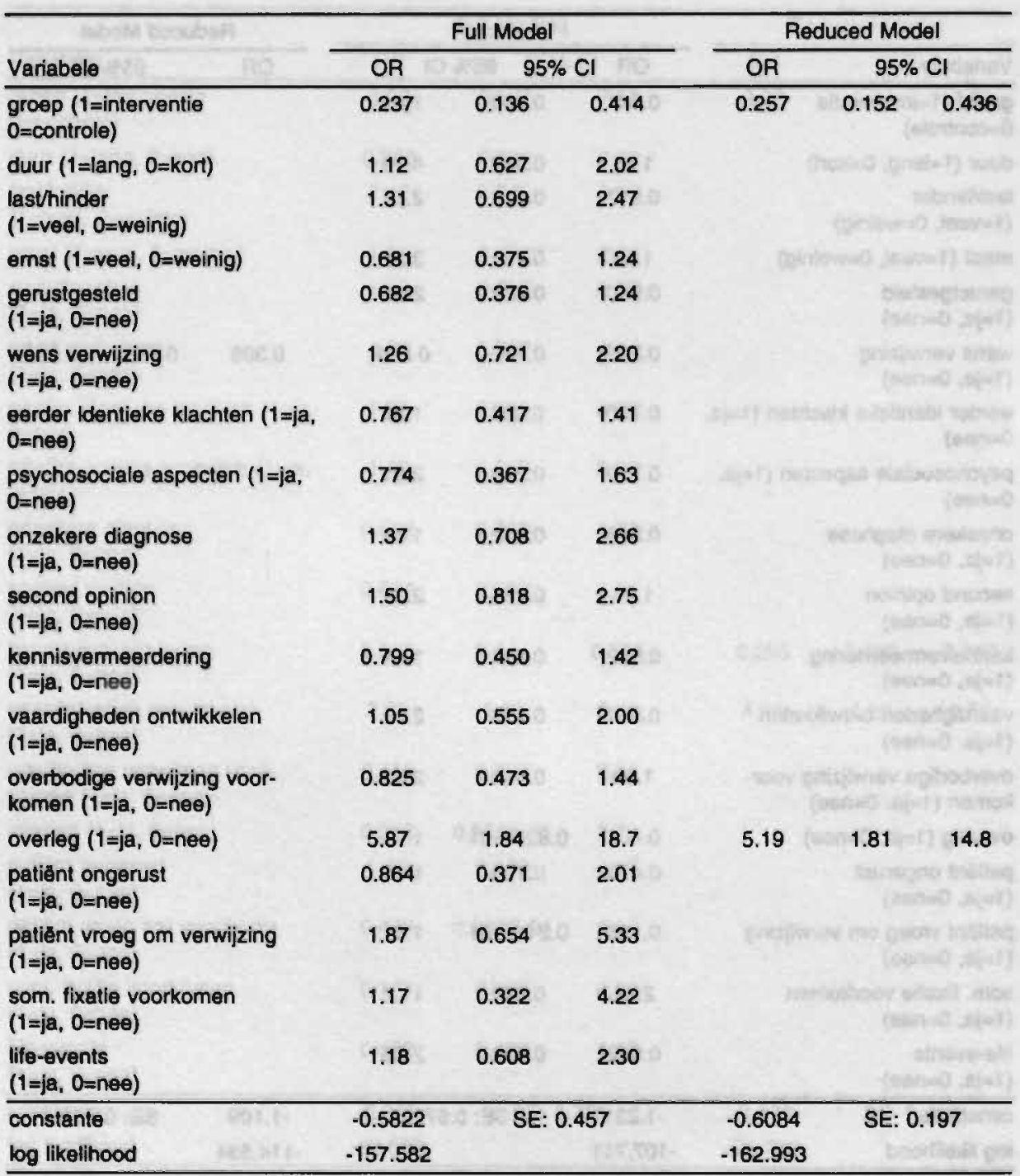




\section{Resultaten van de multipele logistische regressie voor de afhankelijke variabele verwijzing fysiotherapie op voorschrift van de orthopaed"}

\begin{tabular}{|c|c|c|c|c|}
\hline 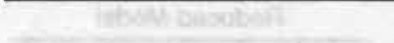 & \multicolumn{3}{|c|}{ Full Model } & Reduced Model \\
\hline \multirow{2}{*}{$\begin{array}{l}\text { Variabele } \\
\text { groep (1=interventie } \\
0=\text { controle) }\end{array}$} & \multirow{2}{*}{$\frac{\mathrm{OR}}{0.518}$} & \multicolumn{2}{|c|}{$95 \% \mathrm{Cl}$} & \multirow{2}{*}{$95 \% \mathrm{Cl}$} \\
\hline & & 0.190 & 1.41 & \\
\hline duur ( 1 =lang, $0=$ kort) & 0.405 & 0.148 & 1.11 & 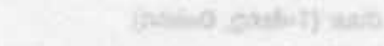 \\
\hline $\begin{array}{l}\text { last/hinder } \\
\text { (1=veel, } 0=\text { weinig) }\end{array}$ & 0.548 & 0.183 & 1.64 & 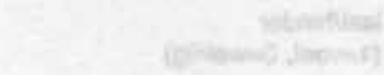 \\
\hline ernst ( 1 =veel, 0 =weinig) & 0.831 & 0.293 & 2.35 & 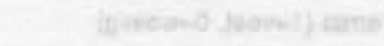 \\
\hline $\begin{array}{l}\text { gerustgesteld } \\
(1=j a, 0=\text { ne日) }\end{array}$ & 1.76 & 0.637 & 4.86 & 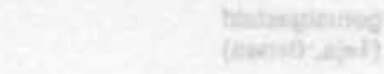 \\
\hline $\begin{array}{l}\text { wens verwijzing } \\
(1=\mathrm{ja}, 0=\text { nee })\end{array}$ & 2.28 & 0.802 & 6.50 & 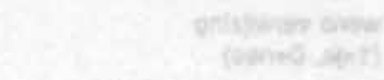 \\
\hline $\begin{array}{l}\text { eerder identieke klachten ( } 1=\mathrm{ja} \text {, } \\
0=\text { nee })\end{array}$ & 1.38 & 0.450 & 4.21 & 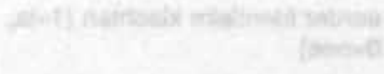 \\
\hline $\begin{array}{l}\text { psychosociale aspecten ( } 1=j a, \\
0=\text { nee) }\end{array}$ & 3.63 & 1.02 & 12.9 & 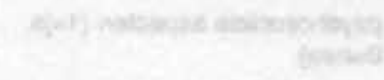 \\
\hline $\begin{array}{l}\text { onzekere diagnose } \\
(1=\mathrm{ja}, 0=\text { nee })\end{array}$ & 1.98 & 0.698 & 5.59 & 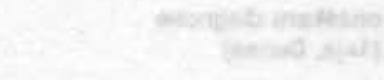 \\
\hline $\begin{array}{l}\text { second opinion } \\
(1=j a, 0=n e \theta)\end{array}$ & 0.929 & 0.331 & 2.61 & foviog prioses: \\
\hline $\begin{array}{l}\text { kennisvermeerdering } \\
(1=\mathrm{ja}, 0=\text { ne日) }\end{array}$ & 1.14 & 0.428 & 3.03 & 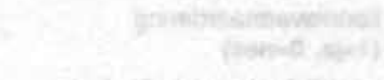 \\
\hline $\begin{array}{l}\text { vaardigheden ontwikkelen } \\
(1=\mathrm{ja}, 0=\mathrm{ne \theta})\end{array}$ & 0.641 & 0.210 & 1.96 & 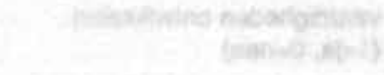 \\
\hline $\begin{array}{l}\text { overbodige verwijzing voor- } \\
\text { komen }(1=j a, 0=n \theta \theta)\end{array}$ & 0.502 & 0.186 & 1.36 & 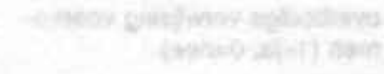 \\
\hline overleg (1=ja, $0=$ nee $)$ & 1.27 & 0.314 & 5.16 & 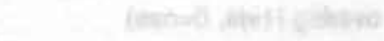 \\
\hline $\begin{array}{l}\text { patiênt ongerust } \\
(1=\mathrm{ja}, 0=\text { nee })\end{array}$ & 0.943 & 0.235 & 3.79 & 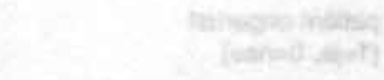 \\
\hline $\begin{array}{l}\text { patient vroeg om verwijzing } \\
(1=j \mathrm{a}, 0=\text { nөө })\end{array}$ & 1.75 & 0.319 & 9.59 & 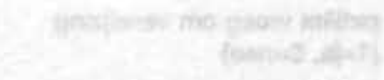 \\
\hline $\begin{array}{l}\text { som. fixatie voorkomen } \\
(1=j a, 0=\text { nee })\end{array}$ & 7.42 & 0.806 & 68.2 & 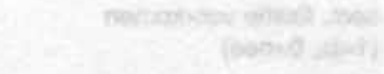 \\
\hline $\begin{array}{l}\text { life-events } \\
(1=j \mathrm{a}, 0=\text { nee })\end{array}$ & 1.16 & 0.405 & 3.35 & $102 x+2$ \\
\hline constante & -0.7590 & SE: 0.7 & 35 & SE: 0.199 \\
\hline log likelihood & -63.968 & & & 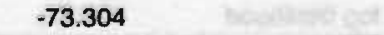 \\
\hline
\end{tabular}




\section{Resultaten van de multipele logistische regressie voor de afhankelijke variabele injecties gegeven door de orthopaed'}

\begin{tabular}{|c|c|c|c|c|}
\hline 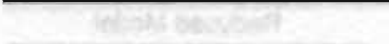 & \multicolumn{3}{|c|}{ Full Model } & Reduced Model \\
\hline Variabele & OR & $95 \%$ & $\mathrm{Cl}$ & $95 \% \mathrm{Cl}$ \\
\hline $\begin{array}{l}\text { groep }(1=\text { interventie } \\
0=\text { controle })\end{array}$ & 0.317 & $0.852 E-01$ & 1.18 & 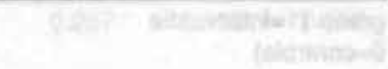 \\
\hline duur ( $1=$ lang, $0=$ kort $)$ & 0.842 & 0.272 & 2.61 & 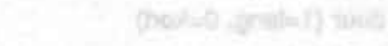 \\
\hline $\begin{array}{l}\text { lasthinder } \\
\text { (1=veel, } 0=\text { weinig) }\end{array}$ & 0.803 & 0.233 & 2.77 & 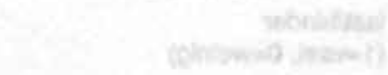 \\
\hline ernst ( 1 =veel, 0 =weinig) & 0.716 & 0.196 & 2.61 & 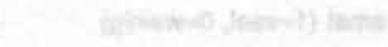 \\
\hline $\begin{array}{l}\text { gerustgesteld } \\
(1=\mathrm{ja}, 0=\text { nee })\end{array}$ & 1.36 & 0.409 & 4.54 & 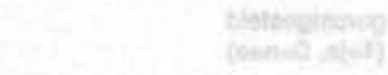 \\
\hline $\begin{array}{l}\text { wens verwijzing } \\
(1=\mathrm{ja}, 0=\text { nee })\end{array}$ & 1.54 & 0.465 & 5.12 & prosinger caye \\
\hline $\begin{array}{l}\text { eerder identieke klachten ( } 1=j a \text {, } \\
0=\text { nee) }\end{array}$ & 1.50 & 0.413 & 5.45 & 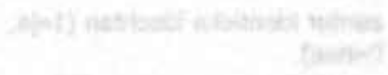 \\
\hline $\begin{array}{l}\text { psychosociale aspecten }(1=\mathrm{ja}, \\
0=\text { ne日) }\end{array}$ & 0.718 & 0.137 & 3.75 & 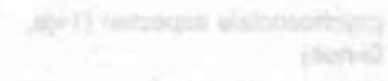 \\
\hline $\begin{array}{l}\text { onzekere diagnose } \\
(1=j a, 0=\text { nee })\end{array}$ & 0.663 & 0.200 & 2.20 & 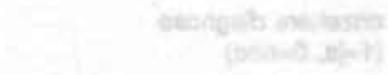 \\
\hline $\begin{array}{l}\text { second opinion } \\
(1=j a, 0=\text { ne日) }\end{array}$ & 0.741 & 0.221 & 2.49 & 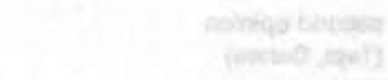 \\
\hline $\begin{array}{l}\text { kennisvermeerdering } \\
(1=\mathrm{j}, 0=\text { =nee })\end{array}$ & 0.611 & 0.206 & 1.81 & 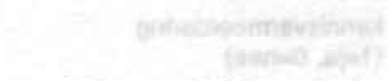 \\
\hline $\begin{array}{l}\text { vaardigheden ontwikkelen } \\
(1=\mathrm{j} a, 0=n e \theta)\end{array}$ & 1.67 & 0.509 & 5.51 & $\begin{array}{lll}2.78 & 1.06 & 7.31\end{array}$ \\
\hline $\begin{array}{l}\text { overbodige venwijzing voorko- } \\
\text { men }(1=\mid \mathrm{a}, 0=\text { nee })\end{array}$ & 1.95 & 0.662 & 5.73 & 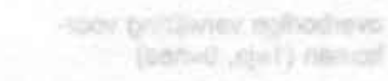 \\
\hline overleg $(1=\mathrm{ja}, 0=$ nee $)$ & 1.11 & 0.216 & 5.72 & 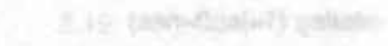 \\
\hline $\begin{array}{l}\text { patiênt ongerust } \\
(1=\mathrm{ja}, 0=\text { nee })\end{array}$ & 0.452 & $0.446 \mathrm{E}-01$ & 4.58 & 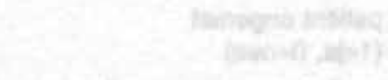 \\
\hline $\begin{array}{l}\text { patient vroeg om verwijzing } \\
(1=j \mathrm{a}, 0=\text { ne日) }\end{array}$ & $0.122 \mathrm{E}-03$ & $0.533 E-27$ & $0.277 E+20$ & 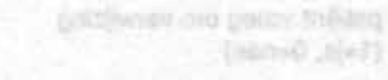 \\
\hline $\begin{array}{l}\text { som. fixatie voorkomen } \\
(1=j \mathrm{a}, 0=n e \theta)\end{array}$ & $0.350 E+03$ & $0.000 E+\infty$ & $0.304 E+32$ & 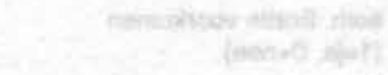 \\
\hline $\begin{array}{l}\text { life-events } \\
(1=\mathrm{ja}, 0=\text { ne日) }\end{array}$ & 1.29 & 0.386 & 4.34 & 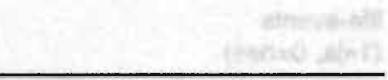 \\
\hline constante & -0.9969 & SE: 0 & .823 & SE: 0.300 \\
\hline log likelihood & -49.249 & & $26 x^{2}=34$ & 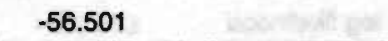 \\
\hline
\end{tabular}




\section{Resultaten van de multipele logistische regressie voor de afhankelijke variabele 'röntgenonderzoek op aanvraag van de orthopaed'}

\begin{tabular}{|c|c|c|c|c|}
\hline 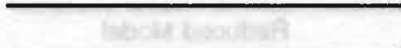 & \multicolumn{3}{|c|}{ Full Model } & Reduced Model \\
\hline Variabele & OR & $95 \% \mathrm{Cl}$ & 1 & $95 \% \mathrm{Cl}$ \\
\hline $\begin{array}{l}\text { groep (1=interventie } \\
0=\text { controle) }\end{array}$ & 0.704 & 0.290 & 1.71 & 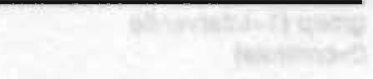 \\
\hline duur ( $1=$ lang, $0=$ kort) & 2.43 & 0.978 & 6.05 & 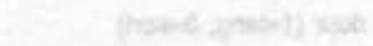 \\
\hline $\begin{array}{l}\text { last/hinder } \\
\text { (1=veel, } 0=\text { =weinig) }\end{array}$ & 2.12 & 0.784 & 5.72 & 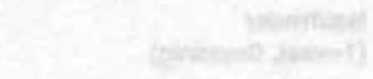 \\
\hline emst ( $1=$ veel, $0=$ weinig) & 0.524 & 0.196 & 1.40 & 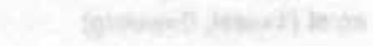 \\
\hline $\begin{array}{l}\text { gerustgesteld } \\
(1=j a, 0=\text { nee })\end{array}$ & 1.15 & 0.458 & 2.89 & 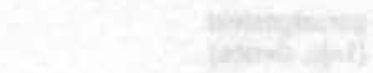 \\
\hline $\begin{array}{l}\text { wens verwijzing } \\
(1=\mathrm{ja}, 0=\text { neө })\end{array}$ & 1.25 & 0.501 & 3.10 & 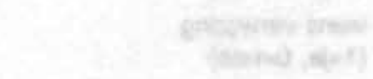 \\
\hline $\begin{array}{l}\text { eerder identieke klachten ( } 1=j a \text {, } \\
0=n \theta \theta)\end{array}$ & 1.24 & 0.476 & 3.25 & 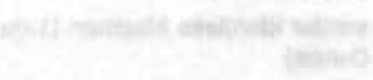 \\
\hline $\begin{array}{l}\text { psychosociale aspecten ( } 1=\mathrm{ja}, \\
0=n \theta \theta)\end{array}$ & 0.597 & 0.179 & 1.99 & 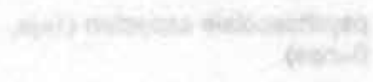 \\
\hline $\begin{array}{l}\text { onzekere diagnose } \\
(1=\mathrm{ja}, 0=\text { nee })\end{array}$ & 2.14 & 0.822 & 5.56 & 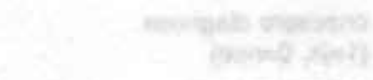 \\
\hline 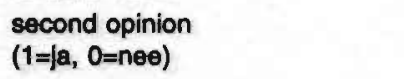 & 0.827 & 0.329 & 2.08 & 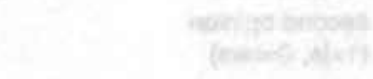 \\
\hline $\begin{array}{l}\text { kennisvermeerdering } \\
(1=j \mathrm{a}, 0=\text { ne日) }\end{array}$ & 1.62 & 0.666 & 3.94 & 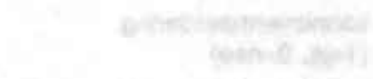 \\
\hline $\begin{array}{l}\text { vaardigheden ontwikkelen } \\
(1=j a, 0=n e \theta)\end{array}$ & 0.673 & 0.247 & 1.84 & 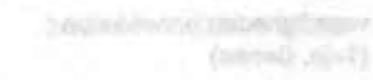 \\
\hline $\begin{array}{l}\text { overbodige verwijzing voorko- } \\
\text { men }(1=\mathrm{ja}, 0=\text { nee })\end{array}$ & 0.477 & 0.198 & 1.15 & 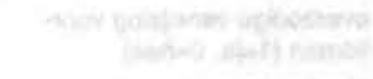 \\
\hline overleg ( $1=\mathrm{ja}, 0=$ nee $)$ & 0.302 & $0.870 E-01$ & 1.05 & 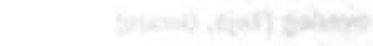 \\
\hline $\begin{array}{l}\text { patient ongerust } \\
(1=j \mathrm{a}, 0=\text { nee })\end{array}$ & 1.42 & 0.402 & 5.02 & 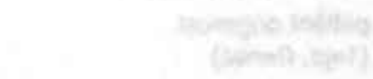 \\
\hline $\begin{array}{l}\text { petient vroeg om verwijzing } \\
(1=j a, 0=\text { nee })\end{array}$ & 0.945 & 0.195 & 4.59 & 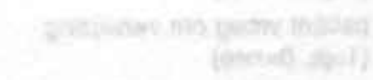 \\
\hline $\begin{array}{l}\text { som. fixatie voorkomen } \\
(1=\mathrm{j}, 0=\text { nee })\end{array}$ & 4.46 & 0.350 & 56.7 & 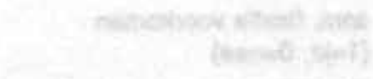 \\
\hline $\begin{array}{l}\text { life-events } \\
(1=j a, 0=n \theta \theta)\end{array}$ & 0.679 & 0.257 & 1.79 & 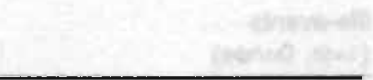 \\
\hline constante & -0.4840 & SE: 0.66 & & SE: 0.183 \\
\hline log likelihood & -73.472 & & $\sqrt{15}$ & 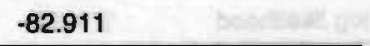 \\
\hline
\end{tabular}




\section{Resultaten van de multipele logistische regressie voor de afhankelijke variabele 'rugklachten, zoals geregistreerd bij het instroomconsult bij de huisarts'}

\begin{tabular}{|c|c|c|c|c|c|}
\hline 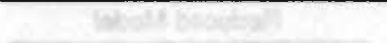 & \multicolumn{3}{|c|}{ Full Model } & \multicolumn{2}{|r|}{ Reduced Model } \\
\hline \multirow{2}{*}{$\begin{array}{l}\text { Variabele } \\
\text { groep (1=interventie } \\
0=\text { controle) }\end{array}$} & \multirow{2}{*}{$\frac{\text { OR }}{1.43}$} & +2 & $95 \% \mathrm{Cl}$ & \multirow[t]{2}{*}{ OR } & $95 \% \mathrm{Cl}$ \\
\hline & & 0.601 & 3.42 & & 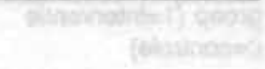 \\
\hline duur ( 1 =lang, $0=$ kort $)$ & 1.38 & 0.539 & 3.55 & & 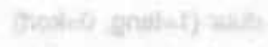 \\
\hline $\begin{array}{l}\text { last/hinder } \\
\text { (1=veel, } 0=\text { weinig) }\end{array}$ & 2.33 & 0.693 & 7.84 & & 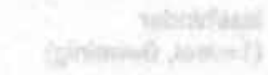 \\
\hline ernst $(1=$ veel, $0=$ weinig $)$ & 1.64 & 0.668 & 4.03 & & 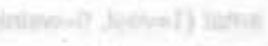 \\
\hline $\begin{array}{l}\text { gerustgesteld } \\
(1=j a, 0=\text { nee })\end{array}$ & 0.753 & 0.291 & 1.95 & & Whengaveg \\
\hline $\begin{array}{l}\text { wens verwijzing } \\
(1=j \mathrm{a}, 0=\text { nee) }\end{array}$ & 0.996 & 0.418 & 2.38 & & 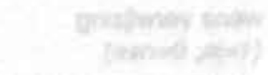 \\
\hline $\begin{array}{l}\text { eerder identieke klachten ( } 1=j a, \\
0=n \theta \theta)\end{array}$ & 1.95 & 0.794 & 4.77 & 2.58 & $1.17 \quad 5.71$ \\
\hline $\begin{array}{l}\text { psychosociale aspecten ( } 1=\mathrm{ja}, \\
0=\text { nee) }\end{array}$ & 1.62 & 0.592 & 4.43 & stanty & 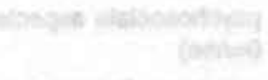 \\
\hline $\begin{array}{l}\text { onzekere diagnose } \\
(1=j a, 0=\text { nee })\end{array}$ & 1.51 & 0.555 & 4.09 & & 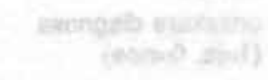 \\
\hline $\begin{array}{l}\text { second opinion } \\
(1=\mathrm{Ja}, 0=\text { nee })\end{array}$ & 0.871 & 0.357 & 2.13 & & 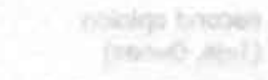 \\
\hline $\begin{array}{l}\text { kennisvermeerdering } \\
(1=\mathrm{ja}, 0=n e \theta)\end{array}$ & 0.788 & 0.321 & 1.93 & & 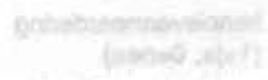 \\
\hline $\begin{array}{l}\text { vaardigheden ontwikkelen } \\
(1=j a, 0=n e \theta)\end{array}$ & 0.307 & $0.833 E-01$ & 1.13 & 0.284 & $0.821 E-01 \quad 0.984$ \\
\hline $\begin{array}{l}\text { overbodige verwijzing voor- } \\
\text { komen }(1=j \mathrm{a}, 0=n e \theta)\end{array}$ & 0.983 & 0.408 & 2.37 & 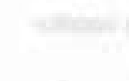 & 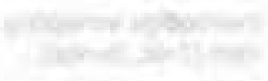 \\
\hline overleg ( $1=\mathrm{ja}, 0=$ nee $)$ & 1.30 & 0.369 & 4.57 & & 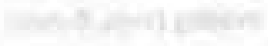 \\
\hline $\begin{array}{l}\text { patiênt ongerust } \\
(1=j \mathrm{j}, 0=\text { nee })\end{array}$ & 0.450 & 0.113 & 1.80 & & 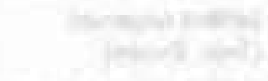 \\
\hline $\begin{array}{l}\text { patiênt vroeg om verwijzing } \\
(1=j \mathrm{a}, 0=\text { nee })\end{array}$ & 0.716 & 0.165 & 3.10 & 36 & 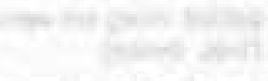 \\
\hline $\begin{array}{l}\text { som. fixatie voorkomen } \\
(1=j \mathrm{~b}, 0=n \theta e)\end{array}$ & 1.10 & 0.192 & 6.25 & & 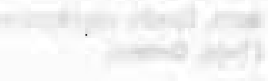 \\
\hline $\begin{array}{l}\text { life-events } \\
(1=j a, 0=n e e)\end{array}$ & 1.79 & 0.716 & 4.47 & & 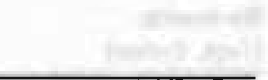 \\
\hline constante & -3.492 & SE: 0 & & -2.271 & SE: 0.298 \\
\hline log likelihood & -80.051 & & & -85.881 & \\
\hline
\end{tabular}


Resultaten van de multipele logistische regressie voor de afhankelijke variabele 'schouderklachten, zoals geregistreerd bij het instroomconsult bij de huisarts'

\begin{tabular}{|c|c|c|c|c|c|}
\hline 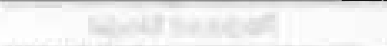 & \multicolumn{3}{|c|}{ Full Model } & \multicolumn{2}{|r|}{ Reduced Model } \\
\hline \multirow{2}{*}{$\begin{array}{l}\text { Variabele } \\
\text { groep (1=interventie } \\
0=\text { controle) }\end{array}$} & \multirow{2}{*}{$\frac{\mathrm{OR}}{2.43}$} & \multicolumn{2}{|c|}{$95 \% \mathrm{Cl}$} & \multirow[t]{2}{*}{ OR } & \multirow{2}{*}{$95 \% \mathrm{Cl}$} \\
\hline & & 1.02 & 5.77 & & \\
\hline duur (1=lang, $0=$ =kort) & 0.830 & 0.354 & 1.95 & & 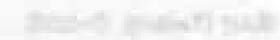 \\
\hline $\begin{array}{l}\text { last/hinder } \\
\text { (1=veel, } 0=\text { weinig) }\end{array}$ & 2.03 & 0.704 & 5.84 & & 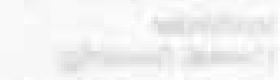 \\
\hline ernst ( $1=$ veel, $0=$ weinig) & 0.956 & 0.393 & 2.33 & & 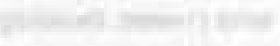 \\
\hline $\begin{array}{l}\text { gerustgesteld } \\
(1=\mathrm{j} a, 0=\text { nee })\end{array}$ & 1.25 & 0.521 & 2.99 & & 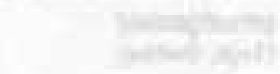 \\
\hline $\begin{array}{l}\text { wens verwijzing } \\
(1=\mathrm{ja}, 0=n e e)\end{array}$ & 0.602 & 0.257 & 1.41 & & $\ln 2=0$ \\
\hline $\begin{array}{l}\text { eerder identieke klachten }(1=j a \text {, } \\
0=\text { neө })\end{array}$ & 1.40 & 0.578 & 3.38 & (11) & 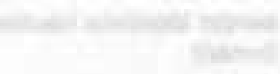 \\
\hline $\begin{array}{l}\text { psychosociale aspecten }(1=\mathrm{ja}, \\
0=\text { nee })\end{array}$ & 3.29 & 1.25 & 8.61 & a & 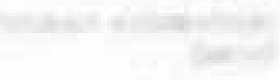 \\
\hline $\begin{array}{l}\text { onzekere diagnose } \\
(1=\mathrm{ja}, 0=\text { nee })\end{array}$ & 0.900 & 0.326 & 2.49 & & 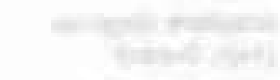 \\
\hline $\begin{array}{l}\text { second opinion } \\
(1=\mathrm{ja}, 0=\text { nee })\end{array}$ & 0.392 & 0.145 & 1.06 & & 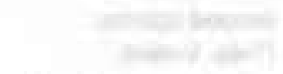 \\
\hline $\begin{array}{l}\text { kennisvermeerdering } \\
(1=\mathrm{ja}, 0=n \theta \theta)\end{array}$ & 1.12 & 0.480 & 2.61 & & 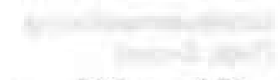 \\
\hline $\begin{array}{l}\text { vaardigheden ontwikkelen } \\
\text { (1=ja, } 0=\text { nee })\end{array}$ & 1.73 & 0.749 & 4.01 & 2.29 & $1.07 \quad 4.88$ \\
\hline $\begin{array}{l}\text { overbodige verwijzing voor- } \\
\text { komen ( } 1=\mathrm{ja}, 0=\text { nee })\end{array}$ & 1.03 & 0.446 & 2.39 & wor: & 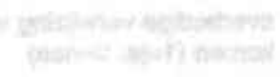 \\
\hline overleg $(1=\mathrm{ja}, 0=$ ne日) & $0.195 E-03$ & $0.619 E-19$ & $0.611 E+12$ & & 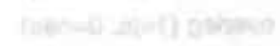 \\
\hline $\begin{array}{l}\text { patiônt ongerust } \\
(1=j a, 0=n e \theta)\end{array}$ & 3.14 & 0.921 & 10.7 & & 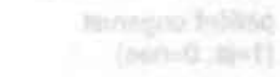 \\
\hline $\begin{array}{l}\text { patiènt vroeg om verwijzing } \\
(1=\mathrm{j}, 0=\text { nee })\end{array}$ & 0.144 & $0.141 E-01$ & 1.46 & 60 & 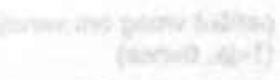 \\
\hline $\begin{array}{l}\text { som. fixatie voorkomen } \\
(1=\mathrm{ja}, 0=\text { nee })\end{array}$ & 0.271 & $0.296 \mathrm{E}-01$ & 2.49 & & 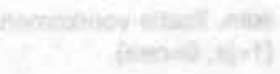 \\
\hline $\begin{array}{l}\text { life-events } \\
(1=\mathrm{ja}, 0=\text { nee })\end{array}$ & 0.682 & 0.241 & 1.93 & & 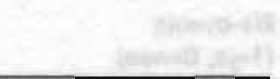 \\
\hline constante & -2.907 & SE: 0 & .755 & -2.215 & SE: 0.241 \\
\hline log likelihood & -82.616 & & wates & -97.107 & 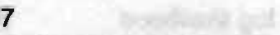 \\
\hline
\end{tabular}


Resultaten van de multipele logistische regressie voor de afhankelijke variabele knieklachten, zoals geregistreerd bij het instroomconsult bij de huisarts'

\begin{tabular}{|c|c|c|c|c|}
\hline 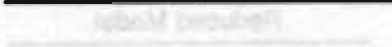 & \multicolumn{3}{|c|}{ Full Model } & Reduced Model \\
\hline Variabele & OR & $95 \% \mathrm{Cl}$ & 1 & $95 \% \mathrm{Cl}$ \\
\hline $\begin{array}{l}\text { groep (1=interventie } \\
0=\text { controle) }\end{array}$ & 0.611 & 0.337 & 1.11 & 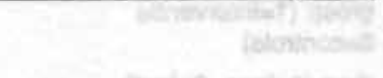 \\
\hline duur ( 1 =lang, $0=$ kort) & 0.800 & 0.422 & 1.52 & 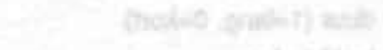 \\
\hline $\begin{array}{l}\text { last/hinder } \\
\text { (1=veel, } 0=\text { weinig) }\end{array}$ & 0.827 & 0.414 & 1.65 & 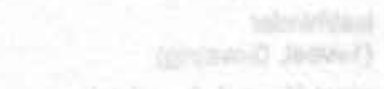 \\
\hline ernst ( 1 =veel, 0 =weinig) & 1.30 & 0.688 & 2.48 & 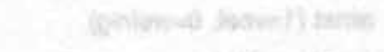 \\
\hline $\begin{array}{l}\text { gerustgesteld } \\
(1=j a, 0=n \theta \theta)\end{array}$ & 0.953 & 0.496 & 1.83 & 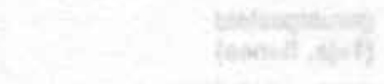 \\
\hline $\begin{array}{l}\text { wens verwijzing } \\
\text { (1=ja, } 0=\text { nee) }\end{array}$ & 1.03 & 0.558 & 1.91 & 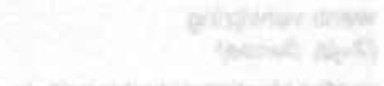 \\
\hline $\begin{array}{l}\text { eerder identieke klachten ( } 1=j \mathrm{a} \text {, } \\
0=\mathrm{n} \theta)\end{array}$ & 1.29 & 0.667 & 2.49 & 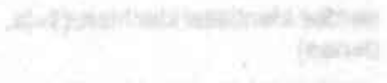 \\
\hline $\begin{array}{l}\text { psychosociale aspecten }(1=\mathrm{ja}, \\
0=\text { nee })\end{array}$ & 0.930 & 0.418 & 2.07 & 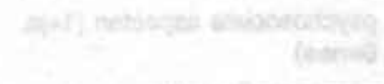 \\
\hline $\begin{array}{l}\text { onzekere diagnose } \\
(1=j a, 0=n \theta \theta)\end{array}$ & 1.48 & 0.747 & 2.92 & 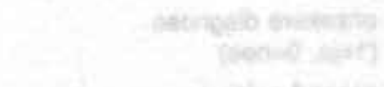 \\
\hline $\begin{array}{l}\text { second opinion } \\
(1=j a, 0=\text { ne })\end{array}$ & 1.27 & 0.667 & 2.43 & 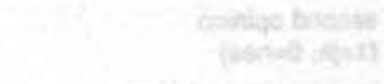 \\
\hline $\begin{array}{l}\text { kennisvermeerdering } \\
(1=\mathrm{ja}, 0=\text { nee })\end{array}$ & 1.35 & 0.713 & 2.55 & 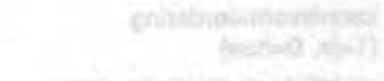 \\
\hline $\begin{array}{l}\text { vaardigheden ontwikkelen } \\
(1=\mid \mathrm{a}, 0=\text { nee })\end{array}$ & 0.451 & 0.205 & 0.994 & $\begin{array}{lll}0.408 & 0.194 & 0.856\end{array}$ \\
\hline $\begin{array}{l}\text { overbodige verwijzing voor- } \\
\text { komen }(1=\mathrm{ja}, 0=\text { ne日) }\end{array}$ & 0.737 & 0.398 & 1.36 & 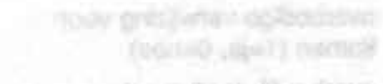 \\
\hline overleg ( $1=j a, 0=$ nee $)$ & 0.730 & 0.252 & 2.11 & 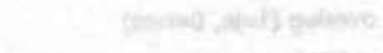 \\
\hline $\begin{array}{l}\text { pationt ongerust } \\
(1=j a, 0=\text { nee })\end{array}$ & 0.988 & 0.401 & 2.43 & 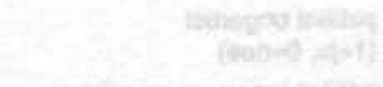 \\
\hline $\begin{array}{l}\text { patient vroeg om verwijzing } \\
(1=j a, 0=n e \theta)\end{array}$ & 3.46 & 1.24 & 9.64 & 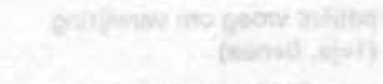 \\
\hline $\begin{array}{l}\text { som. fixatie voorkomen } \\
(1=j a, 0=\text { ne日) }\end{array}$ & 0.756 & 0.174 & 3.29 & 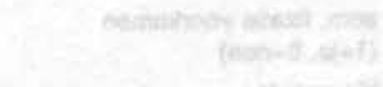 \\
\hline $\begin{array}{l}\text { life-ovents } \\
\text { (1-ja, 0=nee) }\end{array}$ & 0.836 & 0.406 & 1.72 & 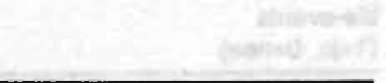 \\
\hline constante & -0.8655 & SE: 0.49 & & SE: 0.159 \\
\hline log likelihood & -138.664 & & & -144.950 \\
\hline
\end{tabular}




\section{Resultaten van de multipele logistische regressie voor de afhankelijke variabele 'enkelklachten, zoals geregistreerd bij het instroomconsult bij de huisarts'}

\begin{tabular}{|c|c|c|c|c|}
\hline \multirow{3}{*}{$\begin{array}{l}\text { Variabele } \\
\text { groep (1=interventie } \\
0=\text { controle) }\end{array}$} & \multicolumn{3}{|c|}{ Full Model } & Reduced Model \\
\hline & \multirow{2}{*}{$\frac{\text { OR }}{0.839}$} & \multicolumn{2}{|c|}{$95 \% \mathrm{Cl}$} & \multirow{2}{*}{$95 \% \mathrm{Cl}$} \\
\hline & & 0.123 & 5.73 & \\
\hline duur ( 1 =lang, $0=$ kort) & 0.227 & $0.315 E-01$ & 1.63 & 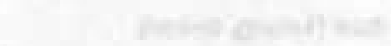 \\
\hline $\begin{array}{l}\text { last/hinder } \\
\text { (1=veel, } 0=\text { weinig) }\end{array}$ & 0.510 & $0.805 E-01$ & 3.23 & 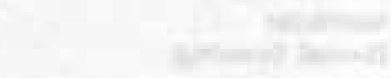 \\
\hline emst (1=veel, 0 =weinig) & 1.68 & 0.221 & 12.7 & 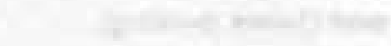 \\
\hline $\begin{array}{l}\text { gerustgesteld } \\
(1=\text { ja, } 0=n e \theta)\end{array}$ & 0.143 & $0.118 E-01$ & 1.74 & 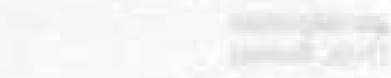 \\
\hline $\begin{array}{l}\text { wens verwijzing } \\
(1=\mathrm{ja}, 0=n e \theta)\end{array}$ & 1.03 & 0.177 & 6.00 & 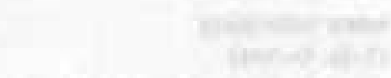 \\
\hline $\begin{array}{l}\text { eerder identieke klachten ( } 1=j a \text {, } \\
0=n \theta e)\end{array}$ & 2.55 & 0.429 & 15.2 & 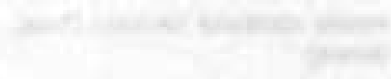 \\
\hline $\begin{array}{l}\text { psychosociale aspecten ( } 1=j a, \\
0=n \theta \theta)\end{array}$ & $0.151 E-02$ & $0.885 E-13$ & $0.256 \mathrm{E}+08$ & 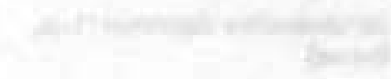 \\
\hline $\begin{array}{l}\text { onzekere diagnose } \\
(1=\mathrm{ja}, 0=\text { nee })\end{array}$ & 0.334 & $0.273 E-01$ & 4.09 & 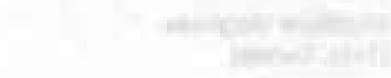 \\
\hline $\begin{array}{l}\text { second opinion } \\
(1=j \mathrm{a}, 0=\text { ne })\end{array}$ & 0.336 & 0.295E-01 & 3.82 & 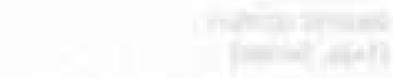 \\
\hline $\begin{array}{l}\text { kennisvermeerdering } \\
(1=\mathrm{ja}, 0=n \theta \theta)\end{array}$ & 8.90 & 0.708 & 112. & 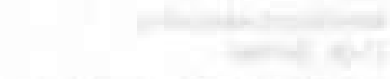 \\
\hline $\begin{array}{l}\text { vaardigheden ontwikkelen } \\
(1=j \mathrm{a}, 0=\text { nee })\end{array}$ & 0.443 & $0.376 E-01$ & 5.23 & 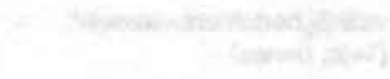 \\
\hline $\begin{array}{l}\text { overbodige verwijzing voor- } \\
\text { komen }(1=j \mathrm{j}, 0=\text { nee) }\end{array}$ & 2.82 & 0.364 & 21.9 & 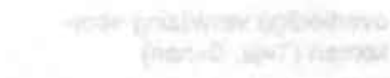 \\
\hline overleg $(1=\mathrm{ja}, 0=n e \theta)$ & 1.41 & $0.842 E-01$ & 23.4 & 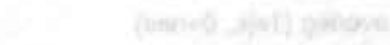 \\
\hline $\begin{array}{l}\text { patient ongerust } \\
(1=\mathrm{ja}, 0=\text { nөe })\end{array}$ & 1.20 & 0.107 & 13.4 & 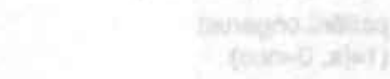 \\
\hline $\begin{array}{l}\text { patient vroeg om verwijzing } \\
(1=j a, 0=n e \theta)\end{array}$ & 2.55 & $0.968 E-01$ & 67.4 & 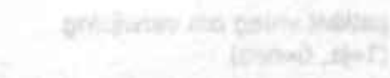 \\
\hline $\begin{array}{l}\text { som. fixatie voorkomen } \\
(1=j a, 0=n e \theta)\end{array}$ & $0.627 E-03$ & $0.845 E-21$ & $0.466 E+15$ & 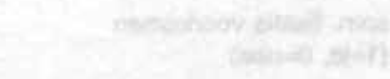 \\
\hline $\begin{array}{l}\text { life-events } \\
(1=j \mathrm{a}, 0=\text { nee })\end{array}$ & $0.122 E-02$ & $0.300 E-12$ & $0.498 E+07$ & 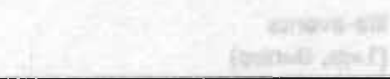 \\
\hline constante & -3.467 & SE: & 1.58 & SE: 0.383 \\
\hline log likelihood & -22.119 & & & $4-x+16 x+10 x$ \\
\hline
\end{tabular}


Resultaten van de multipele logistische regressie voor de afhankelijke variabele heupklachten, zoals geregistreerd bij het instroomconsult bij de huisarts'

\begin{tabular}{|c|c|c|c|c|c|}
\hline 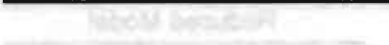 & \multicolumn{3}{|c|}{ Full Model } & \multicolumn{2}{|r|}{ Reduced Model } \\
\hline \multirow{2}{*}{$\begin{array}{l}\text { Variabele } \\
\text { groep (1=interventie } \\
0=\text { controle) }\end{array}$} & OR & \multicolumn{2}{|c|}{$95 \% \mathrm{Cl}$} & \multirow[t]{2}{*}{ OR } & $95 \% \mathrm{Cl}$ \\
\hline & 2.94 & 0.340 & 25.5 & & 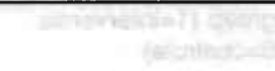 \\
\hline duur ( 1 =lang, $0=$ kort) & 4.12 & 0.482 & 35.2 & & 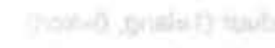 \\
\hline $\begin{array}{l}\text { last/hinder } \\
\text { (1=veel, } 0=\text { weinig) }\end{array}$ & $0.131 E+04$ & $0.988 E-05$ & $0.174 E+12$ & & 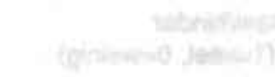 \\
\hline emst ( $1=$ veel, $0=$ weinig) & 1.77 & 0.214 & 14.6 & & 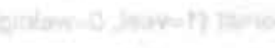 \\
\hline $\begin{array}{l}\text { gerustgesteld } \\
(1=\mathrm{j} a, 0=\text { nee })\end{array}$ & 0.328 & $0.304 E-01$ & 3.53 & & 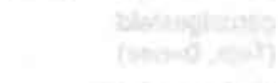 \\
\hline $\begin{array}{l}\text { wens verwijzing } \\
(1=\mathrm{ja}, 0=\text { ne日) }\end{array}$ & 1.22 & 0.157 & 9.57 & & 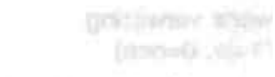 \\
\hline $\begin{array}{l}\text { eerder identieke klachten ( } 1=\mathbf{j a} \text {, } \\
0=\text { nee) }\end{array}$ & 0.515 & $0.705 E-01$ & 3.77 & & 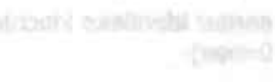 \\
\hline $\begin{array}{l}\text { psychosociale aspecten (1=ja, } \\
0=\text { ne日) }\end{array}$ & 1.82 & 0.252 & 13.2 & & 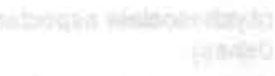 \\
\hline $\begin{array}{l}\text { onzekere diagnose } \\
(1=\mathrm{j}, 0=\text { nee })\end{array}$ & 7.46 & 0.608 & 91.4 & & 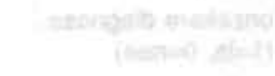 \\
\hline $\begin{array}{l}\text { second opinion } \\
(1=\mathrm{ja}, 0=\mathrm{n} \theta \theta)\end{array}$ & 0.335 & $0.416 \mathrm{E}-01$ & 2.69 & & 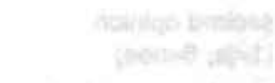 \\
\hline $\begin{array}{l}\text { kennlsvermeerdering } \\
(1=\mathrm{ja}, 0=\text { nee })\end{array}$ & 0.740 & $0.897 E-01$ & 6.11 & & 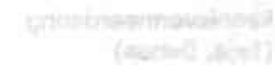 \\
\hline $\begin{array}{l}\text { vaardigheden ontwikkelen } \\
(1=j a, 0=n \theta \theta)\end{array}$ & $0.184 E-02$ & $0.294 E-11$ & $0.115 E+07$ & & 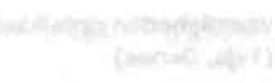 \\
\hline $\begin{array}{l}\text { overbodige verwijzing voor- } \\
\text { komen }(1=\mathrm{ja}, 0=\text { nee })\end{array}$ & 2.22 & 0.213 & 23.1 & $\operatorname{san}$ & 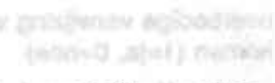 \\
\hline overleg ( $1=\mathrm{j} a, 0=$ nee $)$ & 8.76 & 0.758 & 101. & 7.60 & $\begin{array}{lll}1.59 & 36.3\end{array}$ \\
\hline $\begin{array}{l}\text { patiênt ongerust } \\
\text { (1=ja, } 0=\text { ne日) }\end{array}$ & 2.37 & 0.262 & 21.5 & & 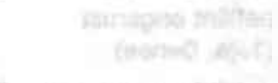 \\
\hline $\begin{array}{l}\text { patient vroeg orn verwijzing } \\
(1=j a, 0=n \theta e)\end{array}$ & 1.24 & $0.702 E-01$ & 22.0 & 2yipt & 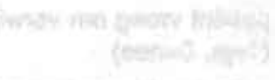 \\
\hline $\begin{array}{l}\text { som. fixatie voorkomen } \\
(1=\mathrm{ja}, 0=\text { ne日) }\end{array}$ & $0.964 E-03$ & $0.130 \mathrm{E}-22$ & $0.718 E+17$ & & 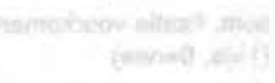 \\
\hline $\begin{array}{l}\text { life-events } \\
(1=j a, 0=\text { nee })\end{array}$ & 0.595 & $0.625 \mathrm{E}-01$ & 5.67 & & 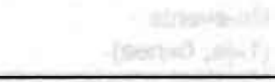 \\
\hline constante & -12.95 & SE: & 9.88 & -4.065 & SE: 0.504 \\
\hline log likelihood & -21.625 & & $54+37$ & -29.591 & 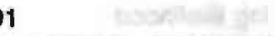 \\
\hline
\end{tabular}




\section{Resultaten van de multipele logistische regressie voor de afhankelijke variabele tendinitidenklachten, zoals geregistreerd bij het instroomconsult bij de huisarts'}

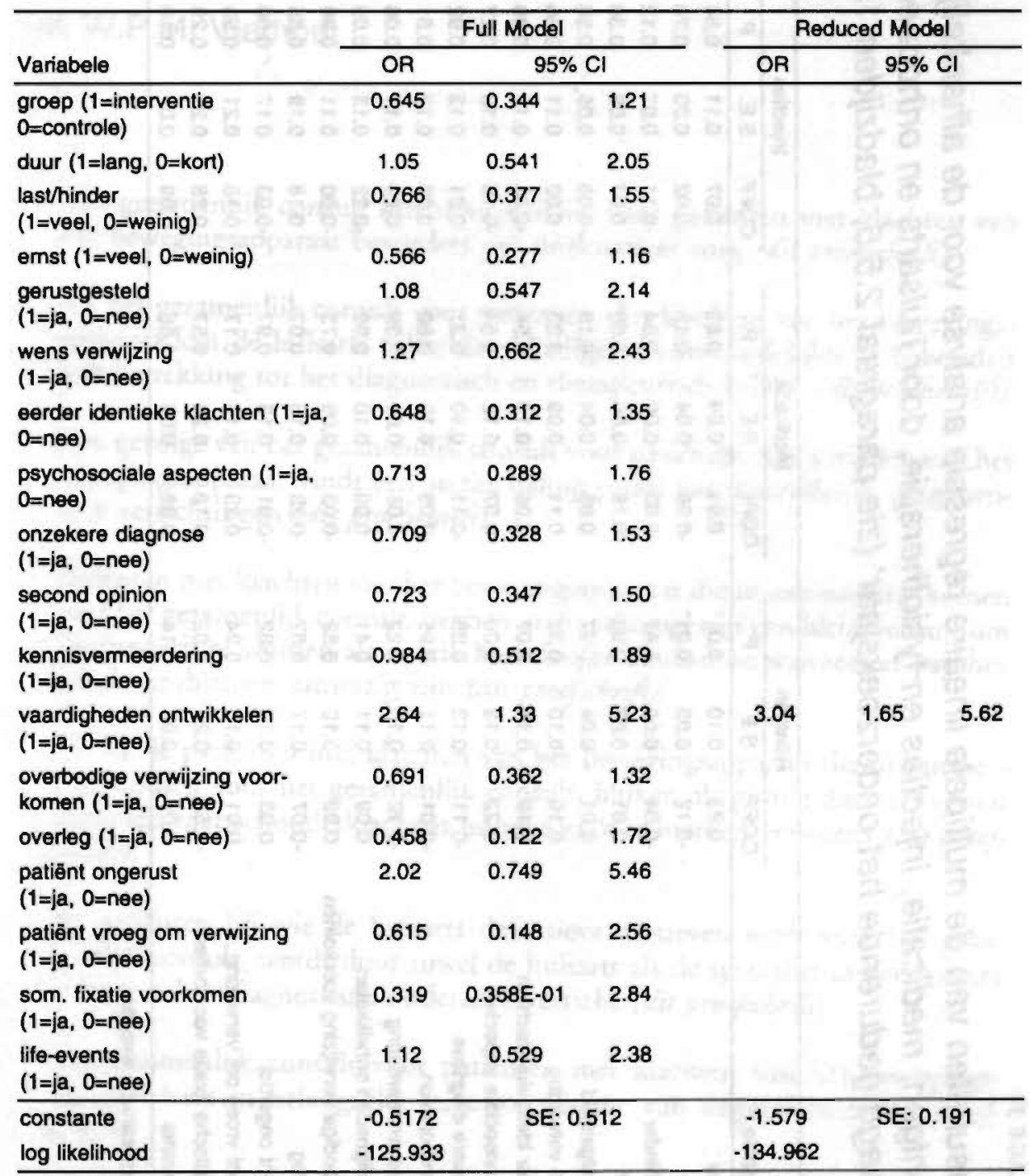


Resultaten van de multipele lineaire regressie analyse voor de afhankelijke variabelen 'röntgen, medicatie, injecties en fysiotherapie, door huisarts en orthopaed tezamen aangevraagd gedurende het onderzoeksjaar' (zie paragraaf 2.5.5, bladzijden 19 en 20)

\begin{tabular}{|c|c|c|c|c|c|c|c|c|c|c|c|c|}
\hline \multirow[b]{2}{*}{ Variabele } & \multicolumn{3}{|c|}{ Rontgen } & \multicolumn{3}{|c|}{ Medicatie } & \multicolumn{3}{|c|}{ Injecties } & \multicolumn{3}{|c|}{ Fyslotherapie } \\
\hline & COFF. & S.E & $\mathbf{P}$ & COFF. & S.E. & $P$ & COFF. & S.E. & $P$ & COFF. & S.E. & $\mathbf{P}$ \\
\hline groep & 0.23 & 0.10 & $0.01^{*}$ & 0.04 & 0.09 & 0.63 & 0.07 & 0.11 & 0.54 & 0.10 & 0.09 & 0.25 \\
\hline duur & -0.12 & 0.05 & $0.01^{\circ}$ & -0.06 & 0.04 & 0.13 & -0.02 & 0.05 & 0.70 & 0.03 & 0.04 & 0.47 \\
\hline last/hinder & -0.04 & 0.06 & 0.47 & -0.03 & 0.06 & 0.64 & -0.11 & 0.07 & 0.12 & -0.07 & 0.06 & 0.22 \\
\hline emst & 0.01 & 0.07 & 0.92 & -0.19 & 0.06 & $0.00^{*}$ & 0.07 & 0.08 & 0.36 & -0.04 & 0.06 & 0.57 \\
\hline genustgesteld & 0.01 & 0.04 & 0.87 & 0.05 & 0.04 & 0.19 & -0.03 & 0.05 & 0.58 & 0.00 & 0.04 & 0.95 \\
\hline wens verwijzing & 0.10 & 0.10 & 0.32 & 0.11 & 0.09 & 0.23 & 0.02 & 0.11 & 0.86 & 0.14 & 0.09 & 0.14 \\
\hline eerder identieke klachten & 0.19 & 0.11 & 0.07 & 0.06 & 0.10 & 0.54 & -0.03 & 0.12 & 0.80 & -0.08 & 0.10 & 0.43 \\
\hline psychosociale aspecten & 0.22 & 0.13 & 0.09 & -0.07 & 0.12 & 0.54 & -0.16 & 0.15 & 0.27 & -0.25 & 0.12 & $0.04^{*}$ \\
\hline onzekere diagnose & -0.11 & 0.12 & 0.35 & -0.11 & 0.10 & 0.31 & 0.01 & 0.13 & 0.92 & -0.04 & 0.11 & 0.73 \\
\hline second opinion & -0.01 & 0.11 & 0.95 & -0.05 & 0.10 & 0.60 & 0.03 & 0.12 & 0.81 & -0.14 & 0.10 & 0.17 \\
\hline kennisvermeerdering & -0.12 & 0.10 & 0.22 & -0.08 & 0.09 & 0.39 & 0.20 & 0.11 & 0.08 & -0.04 & 0.09 & 0.69 \\
\hline vaardigheden ontwikkelen & 0.09 & 0.11 & 0.41 & 0.00 & 0.10 & 0.98 & -0.22 & 0.13 & 0.09 & 0.07 & 0.11 & 0.48 \\
\hline overbodige verwijzing voorkomen & 0.02 & 0.10 & 0.82 & -0.03 & 0.09 & 0.73 & -0.00 & 0.11 & 0.98 & -0.02 & 0.09 & 0.86 \\
\hline overleg & -0.07 & 0.17 & 0.67 & -0.28 & 0.15 & 0.07 & 0.18 & 0.19 & 0.35 & -0.09 & 0.16 & 0.55 \\
\hline patiēnt ongerust & 0.03 & 0.15 & 0.82 & -0.01 & 0.13 & 0.97 & -0.03 & 0.17 & 0.86 & -0.45 & 0.14 & $0.00^{\circ}$ \\
\hline patięnt vroeg om verwijzing & 0.01 & 0.18 & 0.94 & 0.23 & 0.17 & 0.17 & 0.13 & 0.21 & 0.53 & 0.19 & 0.17 & 0.27 \\
\hline somatische fixatie voorkomen & -0.53 & 0.23 & $0.02^{*}$ & 0.12 & 0.20 & 0.57 & 0.28 & 0.26 & 0.28 & -0.40 & 0.21 & 0.06 \\
\hline life-events & 0.09 & 0.06 & 0.14 & 0.02 & 0.05 & 0.66 & 0.09 & 0.07 & 0.19 & -0.08 & 0.05 & 0.15 \\
\hline
\end{tabular}

significante p.waarde 


\section{Het gezamenlijk consult van huisarts en specialist in de eerste lijn}

Een nieuwe werkwijze bij klachten van het bewegingsapparaat

W.P.M. Vierhout

Huisartsen zį̣n over ongeveer $10 \%$ van hun patiëntencontacten ontevreden. Kan het gezamenlijk consult in de huisartspraktijk, voor een groep huisartsen samen met een specialist, hiervoor oplossingen bieden?

Welke patiënten en klachten komen hiervoor in aanmerking?

Is de zorg na een gezamenlijk consult doelmatiger?

Welke motieven hebben huisartsen voor het gezamenlijk consult en verbetert het hun deskundigheid als zij er aan deelnemen?

Is het gezamenlijk consult haalbaar voor huisartsen en specialisten?

Hoe groot is de behoefte bij huisartsen aan het gezamenlijk consult?

Dit onderzoek geeft antwoorden op deze vragen voor patiënten met klachten van het bewegingsapparaat.

W.P.M. Vierhout studeerde Geneeskunde aan de Universiteit van Leiden.

Sinds 1966 is hij werkzaam als huisarts te Maastricht, waarvan sinds 1977 in het gezondheidscentrum 'de Hofhoek'.

Vanaf 1974 is hij als part-time docent verbonden aan de Vakgroep Huisartsgeneeskunde van de Rijksuniversiteit Limburg te Maastricht.

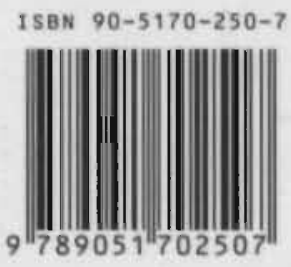

